\title{
AVALIAÇÃO DO DESENVOLVIMENTO INICIAL DE PORTA-ENXERTOS E DE MUDAS DE VIDEIRA OBTIDOS ATRAVÉS DE DIFERENTES MÉTODOS DE PROPAGAÇÃO
}

\section{LUIZ ANTONIO BIASI}

Engenheiro Agrônomo

Orientador: Dr. CELSO VALDEVINO POMMER

Tese apresentada à Escola Superior de Agricultura "Luiz de Queiroz", da Universidade de São Paulo, para obtenção do título de Doutor em Agronomia, Área de Concentração: Fitotecnia.

P I R A C I C A B A

Estado de São Paulo - Brasil

Agosto - 1996 
Biasi, Luiz Antonio

Avaliação do desenvolvimento inicial de porta-enxertos e de mudas de videira obtidos através de diferentes métodos de propagaçāo / Luiz Antonio Biasi. - - Piracicaba, 1996. $177 \mathrm{p}$. : il.

Tese (doutorado) - Escola Superior de Agricultura Luiz de Queiroz, 1996. Bibliografia.

1. Porta - enxerto de uva itália 2. Uva itália - Muda 3. Uva itália - Propagação "in vitro" I. Titulo 


\section{AVALIAÇÃO DO DESENVOLVIMENTO INICIAL DE PORTA-ENXERTOS E DE MUDAS DE VIDEIRA OBTIDOS ATRAVÉS DE DIFERENTES MÉTODOS DE PROPAGAÇÃO}

LUIZ ANTONIO BIASI

Aprovada em: 15.10 .1996

Comissão Julgadora:

Prof. Dr. Maurilo Monteiro Terra

IAC/SP

Prof. Dr. Fernando Mendes Pereira

UNESP/SP

Prof. Dr. Ede Cereda

UNESP/SP

Prof. Dr. João Alexio Scarpare Filho

ESALQ/USP

Prof. Dr. Francisco de Assis Alves Mourão Filho

ESALQ/USP

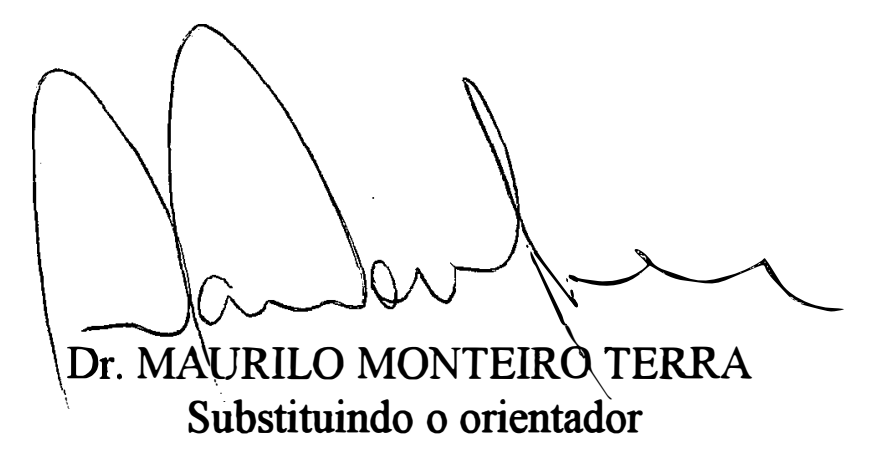




\section{AGRADECIMENTOS}

Ao Dr. Celso Valdevino Pommer pela orientação, apoio e conhecimentos transmitidos para a realização deste trabalho.

À Dra. Ilene Ribeiro da Silva Passos pela experiência e sugestões para a micropropagação dos porta-enxertos.

À Seção de Viticultura do IAC por permitir o uso de suas instalações e materiais para a realização deste trabalho, à ESALQ pela oportunidade de estudo e ao CNPq pela concessão da bolsa de doutorado.

Ao Dr. Maurilo Monteiro Terra e Dr. Erasmo José Paioli Pires pelo agradável convívio e apoio durante a condução dos experimentos.

Ao Dr. Odair Alves Bovi pela permissão de uso dos equipamentos e auxílio na determinação da área foliar dos porta-enxertos.

À Estação Experimental de Monte Alegre do Sul do Instituto Agronômico pela construção dos minirizotrons.

Aos funcionários da Seção de Viticultura do IAC, Nereu, Valdeir, Aparecida, Dolores e André, pela atenção e auxílio prestados.

À minha mãe Irene pelo amor, carinho e apoio em todos os momentos e ao meu pai José pelo amor e ajuda incondicional.

Ao meu irmão Luciano, minha cunhada Christiane e meus sobrinhos Caroline e Luciano, pelo apoio e felicidade que sempre me proporcionaram.

A todos que de alguma forma contribuiram para que fosse possível a conclusão do doutorado e a realização desta tese. 


\section{SUMÁRIO}

\section{Página}

LISTA DE FIGURAS …..............................................................

LISTA DE TABELAS …............................................................

RESUMO …...................................................................

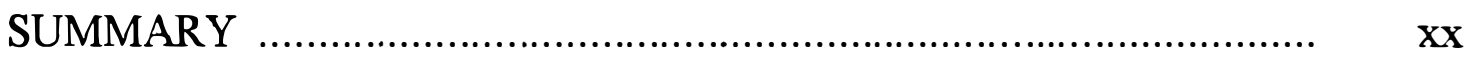

1. INTRODUÇÃO _..................................................................... 01

2. REVISÃO DE LITERATURA .................................................... 03

2.1. Estaquia da videira .............................................................. 03

2.1.1. Fatores que afetam o enraizamento de estacas.................. 05

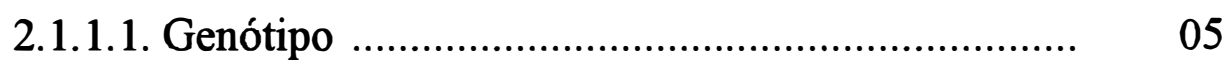

2.1.1.2. Reguladores de crescimento ............................... 06

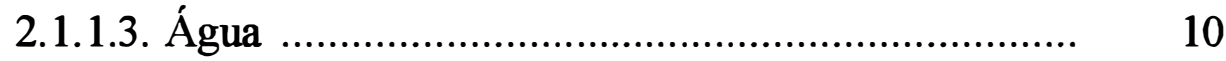

2.1.1.4. Tipo de estaca ................................................ 12

2.1.1.5. Época de estaquia .......................................... 14

2.1.1.6. Substrato ........................................................ 15

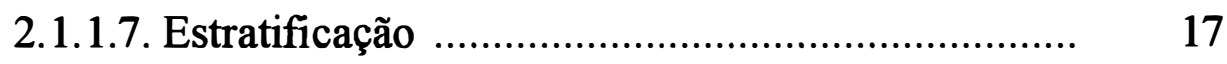

2.2. Enxertia da videira ......................................................... 18

2.2.1. Enxertia a campo …..................................................... 19

2.2.1.1. Enxertia de inverno .......................................... 21

2.2.1.2. Enxertia de verão ............................................. 24

2.2.2. Enxertia de mesa .......................................................... 26 
2.3. Micropropagação da videira .................................................... 29

2.3.1. Fonte de explantes .................................................... 32

2.3.2. Assepsia ................................................................. $\quad 34$

2.3.3. Cultura inicial ........................................................... 34

2.3.4. Multiplicação ............................................................. $\quad 39$

2.3.5. Enraizamento ............................................................. 42

2.3.6. Aclimatização .............................................................. 46

2.3.7. Condições de crescimento .............................................. $\quad 47$

3. MATERIAL E MÉTODOS ...................................................... 51

3.1. Descrição dos cultivares utilizados ............................................ 51

3.2. Experimento de estaquia lenhosa ............................................. 54

3.2.1. Efeito do diâmetro da estaca lenhosa no desenvolvimento dos porta-enxertos 'Jales' e 'Campinas' ............................ 54

3.3. Experimentos de estaquia semilenhosa ................................... 55

3.3.1. Efeito de diferentes formas de preparo no enraizamento de estacas semilenhosas dos porta-enxertos 'Jales', 'Campinas' e 'Tropical' .................................................. 56

3.3.2. Efeito do AIB no enraizamento de estacas semilenhosas dos porta-enxertos 'Jales', 'Campinas', 'Ripária do Traviú' e 'Kober 5BB'

3.3.3. Efeito do AIB no enraizamento de estacas semilenhosas do porta-enxerto 'Tropical'

3.3.4. Efeito da área foliar no enraizamento de estacas semilenhosas dos porta-enxertos 'Jales' e 'Campinas' 
3.3.5. Avaliação do crescimento de mudas dos porta-enxertos 'Tropical', 'Jales' e 'Campinas' obtidas por estaquia semilenhosa

3.4. Experimentos de micropropagação ……................................... 60

3.4.1. Fonte de explantes ...................................................... 60

3.4.2. Condições de crescimento ................................................ 61

3.4.3. Efeito da BAP na indução do crescimento de ápices meristemáticos dos porta-enxertos 'Jales' e 'Campinas'

3.4.4. Efeito do tempo de permanência no meio de indução sobre o crescimento de ápices meristemáticos do porta-enxerto 'Campinas'

3.4.5. Efeito da BAP na indução do crescimento de segmentos nodais do porta-enxerto 'Jales'

3.4.6. Efeito da posição do segmento nodal da brotação das estacas sobre o crescimento dos explantes do portaenxerto 'Jales'

3.4.7. Efeito de diferentes meios de cultura no crescimento do porta-enxerto 'Jales'

3.4.8. Efeito do tamanho da folha do explante durante o subcultivo na multiplicação do porta-enxerto 'Jales'

3.4.9. Efeito da posição do explante durante o subcultivo na multiplicação do porta-enxerto 'Jales'

3.4.10. Efeito de diferentes formas de aclimatização na sobrevivência das plantas do porta-enxerto 'Jales' 
3.5. Comparação do desenvolvimento aéreo e radicular em recipientes de plantas obtidas por estaquia lenhosa e micropropagação dos porta-enxertos 'Jales' e 'Campinas'

3.6. Comparação do desenvolvimento aéreo e radicular em minirizotron de plantas obtidas por estaquia lenhosa $\mathrm{e}$ micropropagação dos porta-enxertos 'Jales' e 'Campinas'

3.7. Avaliação do desenvolvimento inicial a campo de mudas do cultivar Itália produzidas por diferentes métodos de enxertia sobre os porta-enxertos 'Jales' e 'Campinas'

4. RESULTADOS E DISCUSSÃO ................................................... 79

4.1. Experimento de estaquia lenhosa .............................................. 79

4.1.1. Efeito do diâmetro da estaca lenhosa no desenvolvimento dos porta-enxertos 'Jales' e 'Campinas'

4.2. Experimentos de estaquia semilenhosa

4.2.1. Efeito de diferentes formas de preparo no enraizamento de estacas semilenhosas dos porta-enxertos 'Jales', 'Campinas' e 'Tropical'

4.2.2. Efeito do AIB no enraizamento de estacas semilenhosas dos porta-enxertos 'Jales', 'Campinas', 'Ripária do Traviú' e 'Kober 5BB'

4.2.3. Efeito do AIB no enraizamento de estacas semilenhosas do porta-enxerto 'Tropical'

4.2.4. Efeito da área foliar no enraizamento de estacas semilenhosas dos porta-enxertos 'Jales' e 'Campinas' 
4.2.5. Avaliação do crescimento de mudas dos porta-enxertos 'Tropical', 'Jales' e 'Campinas' obtidas por estaquia semilenhosa

4.3. Experimentos de micropropagação

4.3.1. Efeito da BAP na indução do crescimento de ápices meristemáticos dos porta-enxertos 'Jales' e 'Campinas'

4.3.2. Efeito do tempo de permanência no meio de indução sobre o crescimento de ápices meristemáticos do porta-enxerto 'Campinas'

4.3.3. Efeito da BAP na indução do crescimento de segmentos nodais do porta-enxerto 'Jales'

4.3.4. Efeito da posição do segmento nodal da brotação das estacas sobre o crescimento dos explantes do portaenxerto 'Jales'

4.3.5. Efeito de diferentes meios de cultura no crescimento do porta-enxerto 'Jales'.

4.3.6. Efeito do tamanho da folha do explante durante o subcultivo na multiplicação do porta-enxerto 'Jales'

4.3.7. Efeito da posição do explante durante o subcultivo na multiplicação do porta-enxerto 'Jales'

4.3.8. Efeito de diferentes formas de aclimatização na sobrevivência das plantas do porta-enxerto 'Jales'

4.4. Comparação do desenvolvimento aéreo e radicular em recipientes de plantas obtidas por estaquia lenhosa e micropropagação dos porta-enxertos 'Jales' e 'Campinas' 
4.5. Comparação do desenvolvimento aéreo e radicular em minirizotron de plantas obtidas por estaquia lenhosa e micropropagação dos porta-enxertos 'Jales' e 'Campinas'

4.6. Avaliação do desenvolvimento inicial a campo de mudas do cultivar Itália produzidas por diferentes métodos de enxertia sobre os porta-enxertos 'Jales' e 'Campinas'

5. CONCLUSÕES 


\section{LISTA DE FIGURAS}

Página

1. Efeito de diferentes formas de preparo no enraizamento de estacas semilenhosas dos porta-enxertos 'Tropical' (A), 'Jales' (B) e 'Campinas' (C) (Experimento 4.2.1)

2. Efeito de concentrações de AIB na mortalidade de estacas semilenhosas de porta-enxertos de videira (Experimento 4.2.2; apêndice 6). 88

3. Efeito de concentrações de AIB no número de raízes emitidas por estaca semilenhosa de porta-enxertos de videira (Experimento 4.2.2; apêndice 6)

4. Efeito da área foliar sobre o enraizamento de estacas semilenhosas dos porta-enxertos 'Jales' (A) e 'Campinas' (B) (Experimento 4.2.4)

5. Efeito da área foliar sobre o número de raízes emitidas por estaca dos porta-enxertos 'Jales' e 'Campinas' (Experimento 4.2.4; apêndices 9 e 11) 95

6. Efeito da área foliar sobre o peso (g) de raízes emitidas por estaca dos porta-enxertos 'Jales' e 'Campinas' (Experimento 4.2.4; apêndices 9 e 11).

7. Efeito da área foliar sobre o volume $(\mathrm{ml})$ de raízes emitidas por estaca dos porta-enxertos 'Jales' e 'Campinas' (Experimento 4.2.4; apêndices 9 e 11) 
8. Efeito da concentração de BAP na porcentagem de ápices meristemáticos com crescimento dos porta-enxertos 'Jales' (J) e 'Campinas' (C) aos 30 dias após a instalação do experimento (Experimento 4.3.1; apêndices 13 e 14) 100

9. Efeito da concentração de BAP na porcentagem de ápices meristemáticos com crescimento dos porta-enxertos 'Jales' (J) e 'Campinas' (C) aos 60 dias após a instalação do experimento (Experimento 4.3.1; apêndices 13 e 14)

10. Efeito da concentração de BAP na porcentagem de ápices meristemáticos com folha dos porta-enxertos 'Jales' (J) e 'Campinas' (C) aos 30 dias após a instalação do experimento (Experimento 4.3.1; apêndices 13 e 14) 103

11. Efeito da concentração de BAP na porcentagem de ápices meristemáticos com folha dos porta-enxertos 'Jales' (J) e 'Campinas' (C) aos 60 dias após a instalação do experimento (Experimento 4.3.1; apêndices 13 e 14)

12. Efeito do tempo de permanência em meio MS com $10 \mu \mathrm{M}$ de BAP sobre a porcentagem de explantes com crescimento (A), porcentagem de explantes com folha (B) e porcentagem de explantes oxidados $(\mathrm{C})$ do porta-enxerto 'Campinas' (Experimento
4.3.2; apêndice 15) 107

13. Efeito de concentrações de BAP no crescimento das gemas axilares de segmentos nodais do porta-enxerto 'Jales' após 40 dias (Experimento 4.3.3; apêndice 16) 
14. Efeito da posição do segmento nodal da brotação das estacas sobre o crescimento da gema axilar dos explantes do portaenxerto 'Jales' (Experimento 4.3.4; apêndice 17)................................. 11

15. Efeito da posição do explante sobre o crescimento da brotação do porta-enxerto 'Jales' (Experimento 4.3.7; apêndice 20).

16. Efeito da posição do explante sobre a porcentagem de enraizamento (E) e brotação (B) dos segmentos nodais do porta-enxerto 'Jales' (Experimento 4.3.7; apêndice 20) 118

17. Micropropagação do porta-enxerto 'Jales': A-multiplicação in vitro; B-plantas prontas para aclimatização; C-plantas em fase de aclimatização dentro de recipientes fechados em câmara de nebulização; D-planta pronta para plantio em recipientes; E-plantas micropropagadas crescendo ao ar livre

18. Micropropagação do porta-enxerto 'Campinas': A-estacas em brotação para fornecimento de explantes; B-crescimento inicial in vitro; C-plantas recém retiradas dos frascos e prontas para aclimatização; D-plantas em fase de aclimatização dentro de recipientes fechados em câmara de nebulização; E-plantas prontas para plantio em recipientes; F-plantas micropropagadas crescendo ao ar livre

19. Comportamento da área foliar de plantas obtidas de estaca e por micropropagação dos porta-enxertos 'Jales' e 'Campinas' durante o período de 27 de novembro de 1995 a 3 de junho de 1996. Média de três plantas cultivadas em mininizotrons (Experimento 4.5). 
20. Comportamento do comprimento total das brotações de plantas obtidas de estaca e por micropropagação dos porta-enxertos 'Jales' e 'Campinas' durante o período de 27 de novembro de 1995 a 3 de junho de 1996. Média de três plantas cultivadas em mininizotrons (Experimento 4.5)

21. Comportamento do número total de raízes de plantas obtidas de estaca e por micropropagação dos porta-enxertos 'Jales' e 'Campinas' durante o período de 27 de novembro de 1995 a 3 de junho de 1996. Média de três plantas cultivadas em mininzotrons (Experimento 4.5)...

22. Comportamento do comprimento total de raízes de plantas obtidas de estaca e por micropropagação dos porta-enxertos 'Jales' e 'Campinas' durante o período de 27 de novembro de 1995 a 3 de junho de 1996. Média de três plantas cultivadas em mininizotrons (Experimento 4.5)...

23. Comportamento da porcentagem do número de raízes de plantas obtidas de estaca e por micropropagação dos porta-enxertos 'Jales' e 'Campinas' em cinco profundidades $(\mathrm{cm})$ durante o período de 27 de novembro de 1995 a 3 de junho de 1996. Média de três plantas cultivadas em minirizotrons (Experimento 4.5)

24. Comportamento da porcentagem do comprimento de raízes de plantas obtidas de estaca e por micropropagação dos porta-enxertos 'Jales' e 'Campinas' em cinco profundidades $(\mathrm{cm})$ durante o período de 27 de novembro de 1995 a 3 de junho de 1996. Média de três plantas cultivadas em minirizotrons (Experimento 4.5) 
25. Número médio de raízes de plantas obtidas de estaca e por micropropagação dos porta-enxertos 'Jales' e 'Campinas' em cinco profundidades $(\mathrm{cm})$. Média de três plantas cultivadas em mininzotrons (Experimento 4.5)

26. Comprimento médio de raízes de plantas obtidas de estaca e por micropropagação dos porta-enxertos 'Jales' e 'Campinas' em cinco profundidades $(\mathrm{cm})$. Média de três plantas cultivadas em mininizotrons (Experimento 4.5)

27. Comprimento da brotação de mudas de 'Itália' obtidas por diferentes tipos de enxertia sobre os porta-enxertos 'Jales' e 'Campinas' durante o período de 08/11/95 a 09/05/96 (Experimento 4.6) 
1. Procedimentos de assepsia e tipos de explantes utilizados na micropropagação de videiras

2. Condições de temperatura, fotoperíodo e intensidade luminosa utilizados para a micropropagação de videiras

3. Composição química em $\mathrm{mg} / \mathrm{L}$ de alguns meios de cultura utilizados para a micropropagação de videiras

4. Efeito do diâmetro de estacas lenhosas dos porta-enxertos 'Jales' e 'Campinas' sobre o pegamento, número de brotações por estaca e número de folhas por brotação (Experimento 4.1.1; apêndice 1).

5. Efeito do diâmetro de estacas lenhosas de dos porta-enxertos 'Jales' e 'Campinas' sobre o comprimento das brotações e dos entrenós (Experimento 4.1.1; apêndice 1).

6. Efeito da forma de preparo ( $\mathrm{F}=$ ferimento; $\mathrm{N}=$ base com nó; $E=$ base com entrenó) no enraizamento de estacas semilenhosas dos porta-enxertos 'Jales', 'Campinas' e 'Tropical' (Experimento 4.2.1; apêndices 2, 3 e 4)

7. Efeito de concentrações de AIB na propagação dos porta-enxertos 'Jales', 'Ripária do Traviú', 'Campinas' e 'Kober 5BB' através de estacas semilenhosas (Experimento 4.2.2; apêndice 5). 86

8. Efeito de concentrações de AIB no enraizamento de estacas semilenhosas do porta-enxerto 'Tropical' (Experimento 4.2.3; apêndice 7). 
9. Efeito da área foliar no enraizamento de estacas semilenhosas dos porta-enxertos 'Jales' e 'Campinas' (Experimento 4.2.4; apêndices 8 e 10)

10. Avaliação do desenvolvimento de mudas obtidas por estaquia semilenhosa dos porta-enxertos 'Tropical', 'Jales' e 'Campinas' (Experimento 4.2.5; apêndice 12)

11. Efeito da concentração de BAP na porcentagem de oxidação e contaminação de ápices meristemáticos dos porta-enxertos 'Jales' e 'Campinas' após 30 e 60 dias da instalação do experimento (Experimento 4.3.1) 106

12. Efeito de concentrações de BAP na indução da brotação da gema axilar, na oxidação e na formação de calo em segmentos nodais do porta-enxerto 'Jales' após 40•dias (Experimento 4.3.3; apêndice 16).....

13. Efeito da posição do segmento nodal da brotação das estacas sobre a contaminação, oxidação e formação de calo dos explantes do portaenxerto 'Jales' (Experimento 4.3.4; apêndice 17)

14. Efeito de diferentes meios de cultura sobre o crescimento do portaenxerto 'Jales' (Experimento 4.3.5; apêndice 18)

15. Efeito do tamanho da folha do explante na multiplicação do portaenxerto 'Jales' (Experimento 4.3.6; apêndice 19)

16. Efeito da posição do explante na multiplicação do porta-enxerto 'Jales' (Experimento 4.3.7; apêndice 20)

17. Efeito de diferentes formas de aclimatização na sobrevivência das plantas do porta-enxerto 'Jales' (Experimento 4.3.8; apêndice 21). 
18. Comprimento da brotação principal, comprimento total das brotações, comprimento médio dos entrenós e número total de gemas por planta dos porta-enxertos 'Jales' e 'Campinas' obtidos por estaquia e micropropagação (Experimento 4.4; apêndice 22)

19. Diâmetro da brotação principal, peso da parte aérea, peso do sistema radicular e volume do sistema radicular por planta dos porta-enxertos 'Jales' e 'Campinas' obtidos por estaquia e micropropagação (Experimento 4.4; apêndice 23)

20. Porcentagem de falha na estaquia direta a campo dos porta-enxertos 'Jales' e 'Campinas', quatro meses após o plantio (11/11/94) (Experimento 4.6; apêndice 24)

21. Avaliação do desenvolvimento dos porta-enxertos 'Jales' e 'Campinas' antes da enxertia (11/07/95) (Experimento 4.6; apêndice 25)

22. Avaliação do desenvolvimento das mudas obtidas pela enxertia de mesa sete meses após o plantio a campo (15/07/95) (Experimento 4.6; apêndice 26)

23. Comprimento da brotação da copa do cultivar Itália enxertado sobre 'Jales' e 'Campinas' em diversas datas de avaliação (Experimento 4.6; apêndice 27)

24. Peso da copa e diâmetro da brotação do cultivar Itália de mudas dos porta-enxertos 'Jales' e 'Campinas' enxertadas com diferentes tipos de enxertia (Experimento 4.6; apêndice 28). 


\title{
AVALIAÇĀO DO DESENVOLVIMENTO INICIAL DE PORTA-ENXERTOS E DE MUDAS DE VIDEIRA OBTIDOS ATRAVÉS DE DIFERENTES MÉTODOS DE PROPAGAÇÃO
}

\author{
Autor: LUIZ ANTONIO BIASI \\ Orientador: Dr. CELSO VALDEVINO POMMER
}

\section{RESUMO}

Com o objetivo de avaliar o desenvolvimento inicial dos porta-enxertos 'Jales' e 'Campinas' obtidos por estaquia e micropropagação, e também de mudas da videira 'Itália', obtidas através de três tipos de enxertia, foi realizada uma série de experimentos a campo, em casa de vegetação e em laboratório.

Nos experimentos de estaquia foram testados o efeito do diâmetro em estacas lenhosas e os efeitos da forma de preparo das estacas, concentrações de AIB e área foliar em estacas semilenhosas. Os experimentos de micropropagação envolveram testes com concentrações de BAP para indução do crescimento de ápices meristemáticos e segmentos nodais, diferentes meios de cultura, efeito da posição do segmento nodal e do tamanho da folha na multiplicação e enraizamento e formas de aclimatização.

Também foi avaliado o crescimento de porta-enxertos obtidos pela estaquia semilenhosa e comparado o desenvolvimento inicial, em recipientes e em minirizotron, de porta-enxertos obtidos por estaquia lenhosa e micropropagação . 
Num experimento a campo foi avaliado o desenvolvimento de mudas do cultivar Itália, obtidas pela enxertia a campo na estaca original e na brotação do porta-enxerto e pela enxertia de mesa.

O diâmetro das estacas lenhosas não afetou o pegamento, mas as estacas mais grossas originaram mudas mais vigorosas.

A estaquia semilenhosa foi realizada com sucesso, obtendo-se as estacas enraizadas prontas para 0 transplante em 21 dias. As estacas podem ser preparadas com uma gema e uma folha, não sendo necessária a aplicação de AIB.

A micropropagação dos porta-enxertos apresentou-se viável com o uso de ápices meristemáticos e segmentos nodais. Para o cultivo inicial foi necessária a utilização de $10 \mu \mathrm{M}$ de BAP e para a multiplicação foi utilizado meio de cultura MS com a metade da concentração de sais e isento de reguladores de crescimento, obtendo-se de cada explante aproximadamente 3,5 plantas por mês. O enraizamento ocorreu durante a multiplicação e a sobrevivência das plantas foi alta, após a aclimatização em recipientes fechados em câmara de nebulização.

$\mathrm{O}$ crescimento de porta-enxertos obtidos pela estaquia semilenhosa e pela micropropagação foi inferior ao obtido com estacas lenhosas, inviabilizando a enxertia lenhosa de inverno no primeiro ano de plantio.

As mudas do cultivar Itália obtidas pela enxertia de mesa apresentam menor desenvolvimento do que as enxertadas a campo na estaca ou na brotação do porta-enxerto. 


\section{EVALUATION OF THE INITIAL DEVELOPMENT OF ROOTSTOCKS AND GRAFTED GRAPEVINE PLANTS OBTAINED THROUGH DIFFERENT PROPAGATION METHODS}

Author: LUIZ ANTONIO BIASI Adviser: Dr. CELSO VALDEVINO POMMER

\section{SUMMARY}

A series of field, greenhouse, and laboratory trials was accomplished in order to evaluate the initial development of 'Jales' and 'Campinas' grape rootstocks obtained by cuttings and micropropagation and also that of different types of 'Italia' grapevine plants.

The effects of hardwood cuttings diameter and cutting type, AIB concentrations, and leaf area on greenwood cuttings were investigated. The micropropagation experiments involved the test of different BAP concentrations to induce the growth of shoot tips and nodal segments, different culture media, effect of nodal segment position and leaf size on multiplication and rooting, and acclimatization methods.

The growth of rootstock plants obtained by greenwood cuttings was also evaluated and compared to the initial development of plants obtained by hardwood cutting and micropropagation in containers and in mini-rhizotron. 
The development of plants of Italia cultivar obtained by grafting at original wood or at new developed branches of rootstock and by benchgrafting was evaluated in a field trial.

The hardwood cuttings diameter did not affect graft-taking, however, thicker cuttings originated more vigorous plants.

Rooting of the greenwood cuttings was successfully accomplished and plants were ready for transplanting within 21 days. Cuttings may be prepared with one bud and one leaf and AIB application is unnecessary.

The micropropagation of rootstocks was shown to be viable through shoot tips and nodal segments. The use of $10 \mu \mathrm{M}$ of BAP was required for the initial cultivation. MS medium, with the half of the salt concentration and free of growth regulators, was utilized for the multiplication, which gave approximately 3.5 new plants per explant each month. Rooting occurred during multiplication and plant survival was high after acclimation in closed containers under intermittent mist.

The growth of rootstocks obtained by greenwood cuttings and micropropagation was lower than that obtained with hardwood cuttings, leading to the conclusion that winter hardwood grafting is not recommended in the first year of planting.

The development of cultivar Italia plants obtained by benchgrafting was lower than that of field grafting at original wood or at new branches. 


\section{INTRODUÇÃO}

A videira é uma das espécies mais antigas cultivadas pelo homem. Durante séculos as videiras foram propagadas através da estaquia, mas o surgimento da filoxera na Europa, em 1865, determinou uma mudança no processo de produção de mudas, que passaram a ser obtidas pela enxertia sobre videiras de origem americana ou hibrida, que apresentam tolerância a essa praga.

Os porta-enxertos são tradicionalmente obtidos pela estaquia lenhosa, devido à facilidade de enraizamento, de manuseio e de armazenamento deste tipo de estaca. A estaquia pode ser realizada a campo, em viveiros ou diretamente no local definitivo do vinhedo, e também em recipientes individuais. A enxertia é realizada no inverno seguinte pela garfagem do cultivar copa na estaca ou nas brotações do porta-enxerto. Com este processo leva-se no mínimo dois anos para a formação do vinhedo. Por isso, diversos outros métodos também são utilizados visando a formação mais rápida do vinhedo, antecipando o retorno do capital investido. Dentre eles destaca-se a enxertia de mesa, mundialmente conhecida e muito utilizada nos países europeus, onde o processo mecanizado de enxertia permite a produção em massa de grande quantidade de mudas. Este tipo de enxertia é realizado por viveiristas especializados, que possuem equipamentos e estrutura própria para tal. 
A estaquia semilenhosa é utilizada para a multiplicação rápida de videiras quando há escassez de material vegetativo lenhoso e também para a formação de mudas através da enxertia verde em câmara de nebulização.

Mais recentemente, com o surgimento da cultura de tecidos e o estabelecimento de protocolos para a micropropagação de videiras, outros métodos de produção de mudas envolvendo o cultivo in vitro foram desenvolvidos.

$\mathrm{O}$ grande potencial de multiplicação rápida obtido com a micropropagação já é utilizado em muitos países para a obtenção de mudas de videiras muscadíneas e de diversos porta-enxertos. Um método de formação de mudas em uso na Europa envolve a micropropagação dos porta-enxertos e posterior enxertia verde com máquina, obtendo-se rapidamente um número elevado de mudas.

A cultura de tecidos também tem auxiliado na obtenção de clones lívres de vírus através da cultura de meristemas e na multiplicação rápida de novos cultivares quando ainda se dispõe de pouco material de propagação.

Tendo em vista as atuais técnicas de propagação da videira utilizadas no Brasil e em outros países, foram realizados diversos experimentos visando obter informações sobre o comportamento de alguns porta-enxertos, especialmente 'Jales' e 'Campinas' que são muito utilizados na viticultura paulista, quando propagados pela estaquia lenhosa, semilenhosa e micropropagação. Também visando avaliar o desenvolvimento de mudas do cultivar Itália, a mais importante uva fina de mesa cultivada no Brasil, obtidas pela enxertia de mesa e enxertia a campo. 


\section{REVISÃO DE LITERATURA}

\subsection{Estaquia da videira}

A estaquia é o mais empregado e o mais antigo sistema de propagação da videira, seja do porta-enxerto ou do cultivar produtor de uvas.

O tipo de estaca mais utilizado é a lenhosa, coletada durante o período de repouso vegetativo da videira. As estacas devem ser coletadas de plantas matrizes selecionadas e livres de vírus, sendo isentas de brotações secundárias e gavinhas. As exageradamente grossas ou muito finas devem ser rejeitadas, bem como as achatadas, com gemas atrofiadas ou com sinais de pragas ou doenças. As melhores estacas são roliças, com diâmetro semelhante ao de um lápis (Sousa, 1996).

Para as regiões de inverno seco, as estacas são cortadas com $60 \mathrm{~cm}$ de comprimento e para locais irrigados ou com inverno chuvoso, como no Rio Grande do Sul, podem-se utilizar estacas menores, com no mínimo $40 \mathrm{~cm}$. O corte da base das estacas deve ser transversal e bem próximo da última gema, enquanto na parte superior deve ser inclinado e distante da gema. Isto facilita a orientação das estacas no momento do plantio, facilita o enraizamento e evita a perda da gema apical pelo ressecamento da ponta, além de protegê-la de pancadas (Sousa, 1996). 
Dependendo da forma como foram obtidas, as estacas lenhosas podem ser simples, quando constituem-se apenas de um segmento de ramo; cruzeta, quando na parte basal apresentam um segmento do ramo na qual estavam inseridas; e com embasamento, quando apresentam na parte basal apenas um pequeno pedaço do ramo. As estacas com pedaços de ramos velhos apresentam bom enraizamento, mas de cada ramo de um ano, obtém-se apenas uma estaca, sendo, por esta razão, utilizada a estaca simples para a propagação da videira (Gobato, 1940).

A estaquia pode ser realizada diretamente no local onde se instalará o vinhedo no campo, exigindo maiores cuidados, ou em recipientes, obtendo-se geralmente melhor pegamento e com custo mais baixo (Terra et al., 1993).

Além das estacas lenhosas também podem ser utilizadas estacas semilenhosas, coletadas durante o período de crescimento vegetativo da videira (Moretti \& Borgo, 1985). A estaquia semilenhosa é usada para a multiplicação rápida, quando se dispõe de pouco material vegetativo, geralmente para a propagação de novos cultivares livres de vírus (Alley, 1980). Em programas de melhoramento, devido à escassez de material, podem-se utilizar até mesmo estacas herbáceas apicais (Egger et al., 1985).

As estacas semilenhosas com folha também apresentam maior facilidade de enraizamento do que as lenhosas, principalmente em cultivares de difícil enraizamento, como as da espécie Vitis rotundifolia (Goode Junior \& Lane, 1983). 


\subsubsection{Fatores que afetam o enraizamento de estacas}

\subsubsection{Genótipo}

As espécies e variedades do gênero Vitis utilizadas como portaenxertos apresentam uma variação considerável na habilidade para formação de raízes adventícias. Muitas variedades de Vitis vinifera, Vitis riparia, Vitis rupestris e Vitis californica enraizam facilmente (Albuquerque \& Albuquerque, 1981a; Robbins \& Burger, 1986), enquanto outras, como Vitis champinit, Vitis cinerea, Vitis berlandieri e seus híbridos enraizam com mais dificuldade (Blennerhassett \& Considine, 1979; Harmon, 1943; Williams \& Antcliff, 1984).

As videiras muscadíneas da espécie Vitis rotundifolia também apresentam grande dificuldade para propagação através de estacas lenhosas (Cowart \& Savage, 1944; Goode Júnior et al., 1982).

Alvarenga \& Fortes (1976), observando o enraizamento de 11 portaenxertos resistentes a filoxera no Estado de Minas Gerais, encontraram porcentagens de enraizamento acima de $90 \%$ para 'Jales' (IAC 572), 'Teleki 8B', 'RR 101-14', 'IAC 571-6', 'Schwarzmann', 'Campinas' (IAC 766) e 'Tropical' (IAC 313). O '420 A' apresentou cerca de 80\%, o 'Ripária do Traviú' 72\%, enquanto o 'Kober 5BB' e o 'Rupestris du Lot' apresentaram as mais baixas porcentagens de enraizamento, 44 e $27 \%$, respectivamente.

O 'RR 101-14' também foi superior ao 'Ripária do Traviú' e ao 'Kober 5BB' no trabalho realizado por Alvarenga (1976), onde o 'Teleki 8B' não enraizou quando as estacas foram levadas diretamente a campo sem nenhum tratamento adicional. 
Terra et al. (1981) obtiveram menor enraizamento do que Alvarenga \& Fortes (1976), quando não foi utilizado nenhum tratamento. O maior enraizamento foi verificado com o 'Ripária do Traviú' (55\%), seguido pelo 'Campinas' (36\%), 'Jales' (30\%) e 'Kober 5BB' (30\%).

Já Terra et al. (1988b) encontraram taxas de enraizamento superiores a $88 \%$ para os porta-enxertos 'Kober 5BB', '420 A', 'Campinas', 'Ripária do Traviú', 'Jales' e 'Tropical' na estaquia em agosto, com destaque para os dois primeiros que atingiram mais de $96 \%$ de estacas enraizadas.

\subsubsection{Reguladores de crescimento}

Os principais reguladores utilizados para estimular o enraizamento de estacas são as auxinas, com destaque para o ácido indolbutírico (AIB) e o ácido naftalenoacético (ANA). O AIB é o melhor regulador de uso geral porque não é tóxico para a maioria das plantas, mesmo em altas concentrações, e é bastante efetivo para um grande número de espécies (Hartmann et al., 1990). Na videira o ANA apresenta-se, em alguns casos, inferior ao AIB, chegando até mesmo a mostrar-se inibidor do enraizamento (Terra et al., 1981; Pereira et al., 1971).

Entretanto, a auxina nem sempre é o componente químico limitante do enraizamento. Também pode ocorrer uma deficiência de cofatores endógenos do enraizamento, como sistemas enzimáticos adequados $\mathrm{e}$ compostos fenólicos (Hess, 1969). A resposta ao tratamento hormonal depende da condição fisiológica da estaca e a magnitude do fenômeno é resultante do balanço entre as substâncias (auxinas, cofatores e inibidores) aplicadas e as naturalmente presentes nas estacas (Tizio et al., 1963). 
Os porta-enxertos de videira, de maneira geral, parecem não apresentar grandes dificuldades para enraizar, sendo muito pequenas as respostas obtidas com o uso de auxinas. Harmon (1943) testando o AIB em 31 porta-enxertos, obteve aumento no enraizamento de alguns e nos outros a resposta foi variável, o que levou o autor a concluir que não houve efeito benéfico do uso de AIB na propagação comercial de porta-enxertos de videira. Esse fato também foi observado por Pereira et al. (1971) com o 'Ripária do Traviú', o '420 A' e o 'Tropical', cujo tratamento das estacas com soluções diluídas de ANA não proporcionou melhor enraizamento do que a simples imersão em água. Posteriormente, Terra et al. (1981), num experimento semelhante com os porta-enxertos 'Ripária do Traviú', 'Kober 5BB', 'Jales' e 'Campinas', comprovaram que a imersão da base das estacas em água, durante 24 horas, proporcionou enraizamento superior a permanência das estacas em soluções de ANA e igual enraizamento em soluções de AIB.

Leonel \& Rodrigues (1993) trabalharam com o porta-enxerto 'Ripária do Traviú' e da mesma forma que Terra et al. (1981), não observaram diferença significativa entre a aplicação de AIB ou ANA e a testemunha, quanto ao enraizamento das estacas. Contudo, a utilização de $2.000 \mathrm{ppm}$ de AIB propiciou o maior enraizamento $(88,8 \%)$, superior aos obtidos com ANA.

Já Alvarenga (1976) obteve uma resposta positiva com os portaenxertos 'RR 101-14', 'Ripária do Traviú' e 'Kober 5BB' através da aplicação de AIB em pó nas concentrações de 0,1 e $0,3 \%$, mas as testemunhas deste experimento apresentaram porcentagens muito mais 
baixas de enraizamento do que as obtidas com os mesmos porta-enxertos por Terra et al. (1981), Pereira et al. (1971) e Leonel \& Rodrigues (1993).

Coppola \& Forlani (1985) testaram diversas concentrações de AIB por imersão rápida, em estacas de sete porta-enxertos ('420 A', '225 Ru', 'Kober 5BB', '140 Ru', '1045 P', '17-37' e '41 B') com a extremidade superior parafinada ou não. Em todos os cultivares o aumento da concentração de AIB foi acompanhado pelo incremento da porcentagem de enraizamento das estacas. Naquelas parafinadas o AIB foi mais efetivo, sendo que a concentração de 500ppm resultou num efeito semelhante à de 2.000ppm em estacas sem parafina. Ardaiz \& Ruíz (1993) também observaram efeito benéfico da aplicação de AIB em estacas lenhosas do cultivar Zalema.

Estas variações na resposta ao tratamento hormonal possivelmente estão associadas ao estado fisiológico das estacas, pois Trione et al. (1963) observaram uma variação anual na capacidade de enraizamento de estacas dos porta-enxertos 'Kober 5BB' e 'Malbeck', tratadas com auxinas (2,4-D, ANA e AIB) e outras substâncias. Mas apesar desta variação, o tratamento com AIB a 25 ou 50ppm, juntamente com extrato de levedura $0,1 \%$, promoveu o enraizamento mais regular das estacas.

O estado nutricional da planta-matriz também interfere na resposta à aplicação de reguladores. Pearse (1943) obteve um aumento do número e do comprimento das raízes utilizando AIB em pó na base das estacas provenientes de plantas que cresceram em condições de deficiência mineral, mas nenhuma resposta foi observada com estacas de plantas com adequada ou excessiva nutrição e que apresentavam crescimento vigoroso. 
Alguns compostos fenólicos de ocorrência natural parecem estar envolvidos no processo de formação adventícia de raízes (Hess, 1969). A ação dos compostos fenólicos na promoção do enraizamento pode estar, em parte, relacionada com a proteção do ácido indolacético (AIA) da destruição pelo sistema enzimático AIA-oxidase (Hartmann et al., 1990).

Uma série de compostos fenólicos derivados do ácido benzóico (phidroxibenzóico; 2,4 dihidroxibenzóico; 3,4 dihidroxibenzóico) e do ácido cinâmico (t-cinâmico; m-cumárico; p-cumárico; 3,4 dihidroxicinâmico) foram utilizados por Bartolini et al. (1988) no enraizamento de estacas do porta-enxerto '140 Ruggeri', aumentando a porcentagem e a qualidade das raízes produzidas quando utilizados conjuntamente com $2.000 \mathrm{ppm}$ de AIB.

O ácido clorogênico em concentrações de 1 ou $2 \mathrm{ppm}$, aplicado por imersão lenta (24 horas) em estacas herbáceas, proporcionou um enraizamento melhor ou semelhante à utilização de $20 \mathrm{ppm}$ de AIB, para os porta-enxertos 'Kober 5BB' e '1103 P', '110 R' e 'R 2'. A utilização de doses crescentes deste ácido foi acompanhada pelo aumento do enraizamento das estacas, mas seu efeito benéfico foi limitado quando utilizado em mistura com AIB (Moretti \& Borgo, 1985).

O tratamento das plantas matrizes através da pulverização com chlormequat (CCC) na concentração de 500mg/L, aumentou o enraizamento das estacas do porta-enxerto '140 Ruggeri' de 17,5\% na testemunha para 50,8\% e a combinação deste tratamento com a imersão da base das estacas em água durante 24 horas proporcionou a obtenção de $83,3 \%$ de enraizamento (Fabbri et al., 1986). Este efeito benéfico também foi confirmado por Fabbri \& Lambardi (1988) com o mesmo porta-enxerto, 
quanto ao enraizamento e o número de raízes emitidas por estaca, mas quando o CCC foi combinado com a aplicação de 2000ppm de AIB por imersão antes da estaquia, não houve diferença entre as estacas de plantas tratadas e não tratadas.

\subsubsection{3. Água}

Um tratamento muito antigo, de fácil execução e que apresenta bons resultados para estimular o enraizamento, consiste em mergulhar a base das estacas em água durante um período de um ou dois dias (Sousa, 1996). O efeito benéfico deste tratamento é atribuído à lixiviação, durante a imersão em água, de substâncias inibidoras presentes na estaca (Trione et al., 1963).

A imersão em água provoca a liberação de grande quantidade de substâncias semelhantes a giberelinas, além da possibilidade de outros compostos, como sais, glicídios, enzimas e fenóis, também sofrerem difusão, o que levaria ao estabelecimento de um novo equilibrio hormonal endógeno, possivelmente mais favorável ao processo de enraizamento (Bartolini et al., 1986). Estes autores encontraram substâncias semelhantes a giberelinas na água após a imersão por 24 horas de estacas dos portaenxertos 'Kober 5BB' e '140 Ruggeri'. A difusão dessas substâncias foi acelerada pela centrifugação das estacas, sendo que este procedimento e a imersão em água, aumentaram o enraizamento de ambos os cultivares.

O comportamento dos cultivares Malbeck e Kober 5BB, que são considerados de fácil e difícil enraizamento, respectivamente, foi diferenciado quanto a imersão em água. Enquanto 24 horas de imersão 
foram suficientes para o porta-enxerto 'Malbeck', para o 'Kober 5BB' a imersão por 72 horas foi o melhor tratamento, proporcionando a obtenção de $100 \%$ de enraizamento e brotação (Trione et al., 1963).

A simples imersão em água por um período de 24 horas possibilitou enraizamento semelhante ao obtido com o ANA para os porta-enxertos 'Ripária do Traviú', '420 A' e 'Tropical', e superior à testemunha seca (Pereira et al., 1971). Resultados semelhantes foram obtidos por Terra et al. (1981) com os porta-enxertos 'Ripária do Traviú', 'Kober 5BB', 'Jales' e 'Campinas' em relação a aplicação de AIB e ANA.

O pegamento de estacas do porta-enxerto 'Criolla Negra', tratadas com imersão em água por períodos de 12 até 48 horas, foi superior a $90 \%$, enquanto na testemunha seca houve apenas $71 \%$ de pegamento (Bautista et al., 1981). Trabalhando com o mesmo cultivar, Bautista \& Vargas (1984) verificaram que a imersão muito prolongada afetou negativamente o pegamento e crescimento do sistema radicular e brotações. A imersão foi benéfica até o período de 36 horas, a partir do qual passou a aumentar a mortalidade e reduzir o acúmulo de matéria seca. Este efeito resultou possivelmente da lixiviação de substâncias da estaca, provocando uma redução em suas reservas, desincronização entre brotação e enraizamento e problemas fitopatológicos.

Para o porta-enxerto '140 Ruggeri', a imersão das estacas em água por 24 horas promoveu um aumento significativo no enraizamento, passando de $17,5 \%$ para $55 \%$, e no número de raízes emitidas por estaca, aumentando de 1,62 para 2,16 , em relação à testemunha seca. Este tratamento quando combinado com a aplicação de CCC nas plantas 
matrizes resultou em $83,3 \%$ de estacas enraizadas, contra $50,8 \%$ quando se utilizou apenas o CCC (Fabbri et al., 1986).

\subsubsection{Tipo de estaca}

As estacas utilizadas para a propagação de porta-enxertos são normalmente coletadas durante o período de repouso da videira, quando as plantas estão sem folhas e com ramos bem amadurecidos (Alley, 1980). Este tipo de estaca lenhosa apresenta bons resultados de enraizamento para a maioria dos porta-enxertos utilizados comercialmente (Sousa, 1996).

Entretanto, na propagação de cultivares de videiras muscadíneas (Vitis rotundifolia) as estacas lenhosas apresentam grande dificuldade de enraizamento, mesmo com a utilização de reguladores de crescimento (Harmon, 1943; Cowart \& Savage, 1944). Goode Junior et al. (1982) obtiveram apenas $2 \%$ de enraizamento para o cultivar Cowart e $10 \%$ para o Hunt utilizando diversos tratamentos, o que levou os autores a não recomendar esse tipo de estaca para a propagação de cultivares de videiras muscadíneas. Mais recentemente, Castro et al. (1994) trabalhando com o cultivar Dixie, estimularam o enraizamento de estacas lenhosas medianas e basais através do tratamento com baixa temperatura $\left(4^{\circ} \mathrm{C}\right)$ durante 24 horas ou imersão por mesmo período em solução com 10 ou $20 \mathrm{~mL} / \mathrm{L}$ de Exuberone.

A dificuldade de propagação através de estacas lenhosas pode ser superada com a utilização de estacas semilenhosas com folhas mantidas em câmara de nebulização. Sharpe (1954), utilizando esta técnica, chegou a obter $100 \%$ de enraizamento com os cultivares Scuppernong, Thomas e 
Hunt, $90 \%$ com o Wallace, $60 \%$ com o Yuga e 53\% com o Tarheel. Goode Junior \& Lane (1983), num trabalho mais recente com o cultivar Cowart, também obtiveram bons resultados utilizando estacas semilenhosas, alcançando até $90 \%$ de enraizamento.

A presença da folha nas estacas é muito importante pois, juntamente com as gemas, constituem fontes de auxina que, após a produção, é translocada para a base das estacas (Hartmann et al., 1990). A contribuição das folhas no processo de enraizamento também é explicada pela continuação do processo de fotossíntese que leva à produção de carboidratos e sua acumulação na base das estacas (Reuveni \& Raviv, 1981).

A estaquia semilenhosa é utilizada para a multiplicação rápida quando se dispõe de pouco material vegetativo, geralmente para a propagação de novos cultivares livres de vírus (Alley, 1980), podendo, nestes casos, também utilizar a estaquia herbácea, através de ápices vegetativos (Egger et al., 1985).

Warmund et al. (1986), avaliando a propagação do cultivar Vidal Blanc através de estacas lenhosas e semilenhosas, observaram um melhor desenvolvimento do sistema radicular e brotações com as estacas lenhosas, mas a sobrevivência e crescimento posterior a campo foi semelhante. Também foi demonstrado que os tecidos originados de estacas semilenhosas foram mais resistentes às injúrias provocadas pelo frio. 


\subsubsection{5. Época de estaquia}

A época do ano em que é realizada a estaquia, também é fator importante para o enraizamento dos porta-enxertos. O efeito da época de estaquia está relacionado com a condição fisiológica da planta matriz e a lignificação dos ramos no momento de sua coleta (Hartmann et al., 1990), sendo freqüentemente observadas diferenças anuais no enraizamento devido a variações nestas características de um ano para outro (Trione et al., 1963).

Ribas \& Conagin (1957) encontraram, em seus estudos, o período de junho até agosto como a melhor época para a estaquia lenhosa de diversos porta-enxertos no Estado de São Paulo, ressaltando que o plantio precoce é preferível em relação ao tardio.

Alvarenga \& Fortes (1976) obtiveram uma baixa porcentagem de enraizamento para o 'Kober 5BB' em Minas Gerais, atribuindo tal fato à época de plantio (agosto), que foi considerada inadequada para 0 enraizamento. Resultados também baixos de enraizamento foram obtidos por Alvarenga (1976) em Minas Gerais com os porta-enxertos 'RR 101-14', 'Ripária do Traviú', 'Kober 5BB' e 'Teleki 8B' plantados no mês de agosto. Entretanto, Terra et al. (1988b) obtiveram os melhores resultados de enraizamento e desenvolvimento inicial, para 6 porta-enxertos, com o plantio das estacas no mês de agosto em São Paulo, enquanto as menores médias foram obtidas com o plantio em maio.

Bartolini et al. (1986) analisando a água após a imersão por 24 horas de estacas dos porta-enxertos 'Kober 5BB' e '140 Ruggeri', coletadas ao longo do ano, verificaram que, quando a presença de substâncias 
semelhantes a giberelinas na água foi máxima e a presença de substâncias semelhantes a auxinas diminuiu, o enraizamento de ambos cultivares foi mínimo, o que ocorreu nos meses de inverno. Mas o enraizamento das estacas aumentou gradativamente da primavera para o verão, coincidindo com o decréscimo das giberelinas e o reaparecimento das auxinas.

Leonel \& Rodrigues (1993) comparando 3 épocas de estaquia (janeiro, abril e julho) para o porta-enxerto 'Ripária do Traviú', obtiveram os melhores resultados de enraizamento com a coleta das estacas no mês de julho.

\subsubsection{Substrato}

O substrato utilizado para estaquia deve permitir uma boa aeração e não ser sujeito a encharcamento, mas ao mesmo tempo deve reter a umidade necessária para o crescimento das raízes, evitando regas muito freqüentes. $O$ substrato também deve ter a acidez corrigida e ser equilibrado nutricionalmente, além de estar lívre de pragas e doenças, o que é obtido através de sua fumigação com produtos específicos (Hartmann et al., 1990).

Dificilmente um único material satisfaz todas as condições necessárias para um adequado substrato, por isso é comum a mistura de materiais para alcançar este objetivo. Um substrato de fácil confecção para a estaquia lenhosa em recipientes, pode ser obtido através da mistura de terra com adubo orgânico de diversas fontes. O substrato leve é preferível pela sua característica favorável ao enraizamento e facilidade de manuseio 
e transporte, mas não deve ser excessivamente solto para não desfazer 0 torrão durante o plantio (Terra et al., 1993).

A utilização apenas de areia foi considerada inadequada como substrato para o enraizamento de diversos porta-enxertos através da estaquia semilenhosa por Egger et al. (1985), que encontraram os melhores resultados com substratos orgânicos. Terra et al. (1988b) trabalhando com estacas lenhosas de 6 porta-enxertos, também verificaram menor enraizamento e desenvolvimento das plantas em substrato areia e os melhores resultados com o substrato terra.

O enraizamento de estacas lenhosas das espécies $V$. berlandieri e $V$. cinerea, consideradas de propagação difícil, foi obtido por Williams \& Antcliff (1984), em solução nutritiva com aeração forçada, após tratamento das estacas com $2.000 \mathrm{ppm}$ de AIB e permanência em leito aquecido $\left(25^{\circ} \mathrm{C}\right)$ por 4 a 5 semanas. Após abundante enraizamento na solução nutritiva, as plantas foram transferidas para recipientes com uma mistura de perlita e vermiculita e após 8 semanas, com as raízes já lignificadas, foram finalmente transferidas para recipientes com um substrato formado por areia $(50 \%)$, turfa $(20 \%)$, perlita $(15 \%)$, isolita $(10 \%)$ e argila $(5 \%)$.

Ardaiz \& Ruíz (1993), estudando a influência de quatro substratos (vermiculita, sepiolita, perlita e lã de rocha) sobre o enraizamento de Vitis vinifera 'Zalema', obtiveram o maior número de raízes por estaca e o maior comprimento das raízes com vermiculita e sepiolita (hidrosilicato de magnésio). 


\subsubsection{Estratificação}

A estratificação de estacas é utilizada em regiões de clima temperado, onde a videira passa por um período de repouso, com a finalidade de esperar a época adequada para a estaquia e durante este período superar a dormência e aumentar o pegamento das estacas.

Durante o processo de estratificação de estacas, o conteúdo de substâncias inibidoras diminui e a atividade auxínica aumenta. Tizio et al. (1963) estudaram este processo nos cultivares Kober 5BB, Malbeck e Rupestris du Lot, através de bioensaios de germinação e crescimento de coleóptiles de trigo, com extratos das estacas destes porta-enxertos. Os autores verificaram que a emissão de raízes ocorreu quase exclusivamente na região dos nós portadores de gemas ou sobre os calos formados na base das estacas. Este comportamento foi correlacionado com a capacidade de produção de auxinas pelas gemas durante a estratificação, bem como com a diminuição dos inibidores. O conteúdo mais elevado de inibidores nos entrenós parece ser responsável pela ausência de raízes nesta região das estacas. A formação de raízes na base das estacas indica que as auxinas não são destruídas nos entrenós durante o seu movimento polar descendente, mas são inibidas de atuar neste local.

A estratificação de estacas do porta-enxerto Vitis champini 'Ramsey', em areia, em temperaturas de 15 a $20^{\circ} \mathrm{C}$ ou em sacos plásticos a $4^{\circ} \mathrm{C}$, proporciou índices de sobrevivência superiores aos obtidos pela estaquia direta a campo, sendo que a posição horizontal foi mais favorável do que a estratificação vertical ou invertida. Com a estratificação horizontal em 
areia foi possível obter $99,3 \%$ de estacas enraizadas a campo (Blennerhassett \& Considine, 1979).

A estratificação em areia na temperatura ambiente, de estacas do porta-enxerto 'Criolla Negra', por períodos de 7 a 28 dias, proporcionou resultados de pegamento inferiores aos obtidos na testemunha não estratificada. Bautista et al. (1981) atribuiram este fato a problemas fitossanitários, pelo ambiente de estratificação ser úmido, escuro e com temperatura alta $\left(24\right.$ a $\left.26^{\circ} \mathrm{C}\right)$, além de danos causados às brotações e primórdios radiculares durante o transplante.

A utilização de outros ambientes de estratificação, incluindo baixas temperaturas $\left(5^{\circ} \mathrm{C}\right)$, também não foi favorável para o cultivar 'Criolla Negra', evidenciando que nas condições tropicais onde foi realizado este experimento $\left(9^{\circ} 48^{\prime}\right.$ latitude norte), a videira parece não entrar em dormência, sendo que a inibição das gemas laterais deve-se apenas a dominância apical, além deste cultivar apresentar fácil enraizamento, obtendo-se em condições naturais até $100 \%$ de estacas enraizadas (Bautista \& Vargas, 1984).

\subsection{Enxertia da videira}

Após a disseminação da filoxera por toda a área vitícola mundial, o único meio eficiente de se propagar a videira foi através da enxertia, que consiste na união do cultivar produtor de frutos para mesa ou para vinho, sobre porta-enxertos resistentes ou imunes à filoxera e também aos nematóides, que passam a constituir, juntos, um único indíviduo vegetal (Sousa, 1996). 
Além de ser utilizada para a formação de novas mudas, a enxertia também pode servir para a substituição da copa em vinhedos já formados. Neste caso a enxertia em $\mathrm{T}$ lenhoso tem apresentado excelentes resultados em diversas situações na Argentina. A técnica consiste na enxertia de uma gema, sob a casca de plantas adultas, semelhante à borbulhia, mas realizada com gemas retiradas de ramos lenhosos já amadurecidos. A enxertia é realizada durante o período de crescimento vegetativo, quando a casca solta-se facilmente. Para obter as gemas nesta época é preciso coletálas durante a poda de inverno e armazená-las em câmara fria. Logo após a realização dos enxertos (2 a 6 por planta, de acordo com o vigor e desenvolvimento da mesma) elimina-se a copa antiga da planta (Gargiulo, 1976).

Existem diversas formas de propagar a videira através da enxertia, com variações na época de execução, local de realização e processo utilizado. Os métodos mais usuais são a enxertia lenhosa, realizada durante o inverno no campo ou em galpões, e a enxertia verde, realizada durante o período de crescimento vegetativo das plantas (Alley, 1980; Sousa, 1996; Winkler et al., 1974).

\subsubsection{Enxertia a campo}

$\mathrm{Na}$ formação de mudas diretamente a campo, os porta-enxertos podem ser obtidos pela estaquia no local definitivo do vinhedo ou pelo seu crescimento em recipientes e posterior plantio a campo (Terra et al., 1993).

A estaquia direta a campo é realizada nos meses de junho ou julho em covas previamente preparadas, onde colocam-se duas estacas de porta- 
enxertos em cada cova, sendo enterradas até $2 / 3$ do seu comprimento. Imediatamente após o plantio, as estacas devem ser regadas e cobertas com um monte de terra para evitar o seu ressecamento. Em cada cova coloca-se um tutor onde são amarradas as brotações para que cresçam retas. Também é necessário plantar cerca de $30 \%$ a mais de porta-enxertos em recipientes, para posterior reposição de eventuais falhas (Kuhn et al., 1984; Sousa, 1996).

Como o plantio das estacas dos porta-enxertos diretamente no campo exige maior cuidado e alguns cultivares apresentam dificuldade no enraizamento direto a campo, todos os porta-enxertos podem ser enraizados em recipientes e levados posteriormente para o local definitivo. Como prática usual, sacos plásticos são preenchidos com um substrato que, normalmente, é formado por terra de subsolo e adubo orgânico. Desta forma o pegamento é maior. O plantio das estacas nos recipientes também é realizado nos meses de inverno, devendo-se preparar $10 \%$ a mais da quantidade desejada para selecionar as melhores plantas e evitar faltas no plantio. Nos meses de outubro a dezembro, os porta-enxertos enraizados são levados a campo e o saco plástico é retirado de forma a não desmanchar o torrão com a muda (Terra et al., 1993).

Com os porta-enxertos no campo, deve-se zelar pelo seu bom crescimento para que atinjam o desenvolvimento necessário para realizar a enxertia. Por isso é importante que se realize o controle de formigas cortadeiras, o tutoramento das plantas, a construção da bacia para armazenar água da irrigação ou da chuva, a cobertura morta para conservar a umidade do solo e o controle de plantas daninhas (Terra et al., 1993). 


\subsubsection{Enxertia de inverno}

A enxertia de campo no inverno é o processo mais utilizado para a formação dos vinhedos no Brasil (Sousa, 1996).

Esta forma de enxertia proporciona a obtenção de plantas mais vigorosas e produtivas do que aquelas obtidas do plantio de mudas enxertadas. Ribas \& Fraga Junior (1960) verificaram que o cultivar Niagara Rosada enxertada no campo sobre estacas enraizadas e não enraizadas do porta-enxerto 'RR 101-14', produziu em média 47 e 33\%, respectivamente, a mais do que o plantio de mudas já enxertadas, sendo observadas quatro produções comerciais obtidas após o terceiro ano do plantio. A maior porcentagem de falhas $(42,5 \%)$ ocorreu com o plantio de mudas enxertadas, sendo de apenas 7,5 e $3,5 \%$ as falhas com o plantio de estacas enraizadas e não enraizadas, respectivamente. Observou-se também que as plantas enxertadas sobre estacas enraizadas foram sempre as mais vigorosas, resultando em maior produtividade.

O processo mais utilizado para enxertia é a garfagem de topo em fenda cheia (Albuquerque \& Albuquerque, 1981b), também denominada de garfagem simples (Kuhn et al., 1984), podendo também ser utilizada a garfagem de fenda dupla ou inglesa (Peruzzo \& Dal Bó, 1992).

Para realizar a garfagem em fenda cheia, inicialmente faz-se uma limpeza em torno do porta-enxerto para facilitar a operação de enxertia. A seguir escolhe-se no caule do porta-enxerto uma parte lisa e reta, preferencialmente a uma altura de 10 a $15 \mathrm{~cm}$ acima do solo. Neste local faz-se um corte horizontal, eliminando-se a copa. Após, é feita uma fenda 
com o canivete de enxertia de aproximadamente 2 a $4 \mathrm{~cm}$, onde será introduzido o garfo da videira que se deseja enxertar (Kuhn et al., 1984).

Para o preparo do garfo, toma-se uma estaca do cultivar copa, de diâmetro semelhante ao do porta-enxerto, com 2 gemas, e inicia-se o corte a aproximadamente $0,5 \mathrm{~cm}$ da gema inferior, em ambos os lados, de maneira a formar uma cunha. $\mathrm{O}$ comprimento desta deverá ser semelhante à profundidade da fenda feita no porta-enxerto, sendo o preparo do garfo feito com cortes rápidos e firmes, de maneira a ficarem bem lisos. É importante que o garfo seja imediatamente encaixado na fenda do portaenxerto, assim que preparado, de tal maneira que as regiões da casca do porta-enxerto e do garfo estejam em contato direto, em pelo menos um dos lados. A seguir, amarra-se o enxerto com firmeza, não deixando os cortes expostos (Kuhn et al., 1984).

Após a enxertia cobre-se o enxerto com terra, mas é muito importante a remoção da terra após a emissão da brotação do garfo, para evitar o franqueamento, ou seja, enraizamento do enxerto. Em caso de que isso ocorra, as raízes devem ser cortadas com uma tesoura de poda (Kuhn et al., 1984).

Para amarrar o enxerto pode-se utilizar fita plástica, que forma uma câmara úmida no local da enxertia, preservando-a da desidratação (Albuquerque \& Albuquerque, 1981b). Mas a fita plástica pode trazer problemas no pegamento da enxertia, pois este material pode restringir a aeração necessária para a formação do calo, responsável pela união dos tecidos, já que a rápida divisão celular e o crescimento destes tecidos são acompanhados de maior respiração e exigência em oxigênio (Hartmann et 
al., 1990). A cobertura dos enxertos de 'Niagara Rosada' sobre 'Rupestris du Lot' com plástico prejudicou o pegamento resultando no pior tratamento obtido por Sampaio (1978) com apenas 6,6\% dos enxertos vingados. O uso de mastique também foi inferior ao tratamento onde o enxerto foi amarrado com barbante e coberto com terra, que resultou em $78 \%$ de pegamento.

Entretanto, a cobertura do enxerto com solo tem reflexos diretos no aumento da mão-de-obra e na qualidade fitossanitária da muda. $\mathrm{O}$ aumento da mão-de-obra e, conseqüentemente, do custo da muda advém da necessidade de cobertura total do enxerto com o solo, bem como de repetir esta operação várias vezes em virtude da necessidade de descobrir o portaenxerto para desbrotá-lo durante o tempo de cicatrização da enxertia. A qualidade fitossanitária da muda pode ser comprometida pela penetração de patógenos no local da enxertia, principalmente por fungos do gênero Fusarium (Peruzzo \& Dal Bó, 1992).

Uma alternativa interessante para este problema é o uso de Parafilm M, um material plástico de características flexíveis e que permite a retenção da umidade no local coberto. Este material substitui a cobertura com solo possibilitando um bom pegamento e a redução da mão-de-obra nas atividades posteriores à enxertia (Peruzzo \& Dal Bó, 1992).

Para evitar a cobertura do enxerto com terra, também pode-se realizar a enxertia alta, nas brotações do porta-enxerto. Neste processo realiza-se a enxertia em dois ou três ramos vigorosos do porta-enxerto, deixando os restantes para evitar uma saída excessiva de seiva pelos ramos enxertados, o que resultaria em baixo índice de pegamento. Quando a brotação do garfo estiver com cerca de $40 \mathrm{~cm}$ de comprimento eliminam-se 
os ramos do porta-enxerto (Albuquerque \& Albuquerque, 1981b; Terra et al., 1993).

\subsubsection{Enxertia de verão}

A enxertia de campo por garfagem no inverno, como visto anteriormente, é a prática mais utilizada para a formação de mudas de videira no Brasil. Através deste processo, geralmente obtém-se uma boa porcentagem de pegamento, porém é comum ocorrerem falhas, havendo a necessidade de novas enxertias no inverno seguinte para completar o vinhedo (Camargo, 1992)..

Para uma reposição mais rápida das falhas da enxertia de inverno é recomendada a enxertia verde durante a primavera, permitindo que se complete o vinhedo ainda no primeiro ciclo vegetativo. Mas a enxertia verde também pode ser utilizada como método principal para a formação do vinhedo (Camargo, 1992; Sousa, 1996).

A época da enxertia depende do desenvolvimento do porta-enxerto, mas normalmente é realizada nos meses de novembro a janeiro. Dentro deste período, quanto mais cedo for realizada a enxertia melhor, pois, assim as brotações terão mais tempo para crescer, reduzindo os problemas de maturação, especialmente em anos com geadas no outono (Alvarenga, 1984; Camargo, 1992).

Os métodos utilizados para a enxertia de verão são a garfagem simples (Camargo, 1992), a borbulhia em T invertido e a borbulhia em placa embutida (Alvarenga et al., 1977). 
A enxertia de verão, pelo método da borbulhia, apresenta as seguintes vantagens em relação à enxertia por garfagem de inverno: método simples e que exige pouca experiência do enxertador, elevada porcentagem de pegamento, obtenção das mudas com 10 a 12 meses a partir da estaca não enraizada e enxertia alta que não permite o franqueamento da planta (Alvarenga, 1984).

O método da borbulhia em placa embutida possibilitou a obtenção de 93,7\% de pegamento de enxertos de 'Niagara Rosada' sobre 8 portaenxertos, superior ao obtido com a borbulhia em $\mathrm{T}$ invertido $(82,5 \%)$, mas ambos os tipos de borbulhia foram melhores do que a garfagem de topo em fenda cheia, onde ocorreu apenas $30,6 \%$ de pegamento. Neste trabalho as mudas foram obtidas com pouco menos de 11 meses (Alvarenga et al., 1977).

Camargo (1992) afirmou que a porcentagem de pegamento da enxertia verde por garfagem é superior a $95 \%$, sendo realizada através da seguinte técnica: selecionam-se dois ramos no início da brotação do portaenxerto, conduzindo-os adequadamente através de amarrações períodicas ao tutor; os garfos, sem folhas, devem ser coletados no dia da enxertia, utilizando-se de quatro a seis gemas da parte mediana do ramo, sendo acondicionados em sacos plásticos contendo jornal úmido, para evitar a desidratação; a enxertia pode ser realizada a partir do quarto ou quinto entrenó, contado da extremidade para a base da brotação do porta-enxerto; todas as gemas do porta-enxerto devem ser eliminadas, contudo, as folhas devem permanecer; após a enxertia do garfo com duas gemas, deve-se proteger o enxerto com plástico fino, vedando totalmente a superfície 
desde a região de enxertia até o ápice, ficando descobertas apenas as suas gemas; as brotações do porta-enxerto devem ser eliminadas periodicamente; após a brotação do enxerto, devem ser iniciados os tratamentos fitossanitários e efetuadas as amarrações no tutor; cerca de dois meses após a enxertia, deve-se afrouxar a fita plástica para evitar o estrangulamento sem, contudo, retirá-la, para evitar o ressecamento do calo de cicatrização; a fita poderá ser retirada aproximadamente um mês após a operação anterior.

$\mathrm{Na}$ enxertia por borbulhia em placa embutida, o porta-enxerto recebe um corte oblíquo para baixo, fazendo um ângulo de $45^{\circ} \mathrm{com}$ o seu eixo longitudinal. Aproximadamente $3 \mathrm{~cm}$ acima deste, faz-se o segundo corte, formando um ângulo agudo com o primeiro, até encontrá-lo, removendo-se o pedaço do caule. Faz-se a mesma operação na haste que contém as borbulhas, obtendo-se perfeita coincidência da borbulha com a incisão do porta-enxerto e amarra-se com fita plástica, deixando-se a gema descoberta. Decorridos 20 dias da enxertia, efetua-se a decapitação do porta-enxerto (Alvarenga, 1984).

\subsubsection{Enxertia de mesa}

Os métodos tradicionais de enxertia a campo, muitas vezes apresentam falhas na enxertia resultando em desuniformidade inicial, além da demora na formação de vinhedo, que atrasa o retorno do capital investido. Por isso, em muitos países utiliza-se a enxertia de mesa (Piccoli, 1989). 
Através da enxertia de mesa é possível obter a muda no final da primavera ou início do verão e formar o vinhedo ainda no mesmo ano. Para realizar a enxertia de mesa foram desenvolvidas máquinas especiais, sendo creditado a H. E. Jacob a invenção da primeira máquina na Califórnia em 1936, sendo posteriormente patenteada outra máquina na Áustria, por Albert Hengel. Esta máquina produz uma série de cortes que servem de encaixe para a enxertia. Mais recentemente, uma máquina alemã com o corte em ômega vem sendo largamente utilizada na Europa, devido ao seu alto rendimento (Alley, 1980).

A enxertia de mesa também pode ser realizada manualmente através do corte em dupla fenda ou inglês complicado (Silva et al., 1986; Sousa, 1996) ou pela garfagem de topo em fenda cheia (Shimoya et al., 1971).

Para a enxertia manual, as estacas dos porta-enxertos devem ter diâmetro entre 0,6 a $1,5 \mathrm{~cm}$ e 3 a 5 gemas, com comprimento entre 25 a $30 \mathrm{~cm}$. Todas as gemas da estaca são retiradas, com exceção da basal, e logo abaixo desta gema não cegada faz-se um corte perpendicularmente à base. $\mathrm{Na}$ extremidade superior do porta-enxerto se efetua o corte conforme o tipo de enxertia. O garfo, com uma gema da variedade copa, é preparado com um corte perpendicular a cerca de $1,5 \mathrm{~cm}$ acima da gema e na parte inferior é feito o encaixe combinando com aquele do porta-enxerto. Unemse as partes e amarra-se com barbante para dar firmeza entre as partes unidas (Piccoli, 1989).

Para aumentar a porcentagem de pegamento pode-se tratar as estacas enxertadas com AIB. Silva et al. (1986) trabalhando com estacas dos porta-enxertos 'SO4', 'Rupestris du Lot' e 'RR 101-14' enxertadas com o 
cultivar Merlot obtiveram aumentos significativos na pega da enxertia, na porcentagem de estacas enraizadas e no número e comprimento de raízes com o tratamento por imersão rápida da base em solução de AIB. A concentração ideal do regulador variou entre os porta-enxertos, atingindo os maiores valores de pega com $1.250,2.470$ e $4.000 \mathrm{ppm}$ de AIB para os porta-enxertos 'RR 101-14', 'SO4' e 'Rupestris du Lot', respectivamente.

Para estimular a cicatrização e o pegamento, as estacas enxertadas são levadas para uma "câmara de forçagem", onde a temperatura e a umidade são controladas. A temperatura deve ser mantida entre 25 a $30^{\circ} \mathrm{C}$ e a umidade do ar entre 80 a $90 \%$ para facilitar a cicatrização da enxertia. As estacas enxertadas podem ser colocadas em pé dentro de caixas plásticas ou de madeira, preenchidas com um substrato formado preferencialmente por pó de xaxim, serragem ou carvão vegetal em pó. Nestas condições, a brotação do enxerto ocorre aproximadamente 10 dias após a enxertia e com cerca de 30 dias as mudas já podem ser retiradas da câmara. Para aumentar a sobrevivência das mudas, deve ser realizada uma aclimatação gradual, inicialmente aumentando o número de horas de exposição à luz solar na primeira semana e em seguida transferindo as mudas para recipientes individuais, onde elas permanecem pelo menos 20 dias, até que estejam suficientemente desenvolvidas para serem levadas para o viveiro ou para o local definitivo (Sousa, 1996; Peruzzo, 1995; Piccoli, 1989).

Bindra et al. (1974), testando temperaturas de 12,20 e $26^{\circ} \mathrm{C}$ para a união de várias combinações de enxertos, verificaram que a temperatura mais alta foi a mais favorável. Os autores também verificaram que o 
melhor substrato para a estratificação das estacas enxertadas foi solo com $0,9 \%$ de matéria orgânica, superior à areia e à serragem.

A cobertura da região enxertada com substrato durante a estratificação foi considerada desnecessária por Romberger et al. (1979), que testaram doze combinações entre enxertos e porta-enxertos. Neste caso o enxerto foi protegido com cera e o substrato utilizado foi uma mistura de turfa, vermiculita e areia para revestir o porta-enxerto e serragem seca para revestir o local de enxertia.

O período de estratificação é importante pois a emergência das raízes adventícias ocorre com cerca de 22 a 30 dias de idade, havendo uma relação perfeita entre o desenvolvimento das raízes adventícias nas estacas com o fenômeno de soldadura do enxerto (Shimoya et al., 1971).

\subsection{Micropropagação da videira}

A micropropagação de videiras consiste basicamente no processo de enraizamento de brotações axilares ou adventícias multiplicadas in vitro, para a regeneração de plantas inteiras. Este processo possibilita a rápida multiplicação de plantas, a obtenção de plantas-matrizes livres de vírus, a propagação de híbridos e a preservação de germoplasmas de interesse (Krul \& Mowbray, 1984).

Para a videira, a micropropagação baseia-se em dois métodos principais. O mais utilizado segue o procedimento tradicional, descrito por Murashige (1974), com três fases distintas: o estabelecimento das culturas assépticas, a multiplicação e o enraizamento das brotações. O outro método baseia-se na produção adventícia de brotações, originárias de estruturas 
semelhantes a folhas, obtidas a partir de ápices meristemáticos fragmentados (Barlass \& Skene, 1978; Barlass \& Skene, 1980a; Barlass \& Skene, 1980b; Barlass et al., 1981; Skene \& Barlass, 1980; Skene \& Barlass, 1983).

Através das técnicas de cultura de meristemas e de ápices fragmentados, em conjunto com a termoterapia, foi possível a obtenção de clones livres de vírus, que dificilmente eram eliminados apenas com o tratamento térmico (Barlass et al., 1982; Koruza \& Jelaska, 1993). Estas técnicas também aumentaram a eficiência da limpeza viral, atingindo-se, em casos como o do trabalho de Barlass (1987), 100\% de plantas sadias indexadas para os vírus do intumescimento dos ramos (corky bark) e das caneluras do tronco (stem pitting).

$\mathrm{O}$ isolamento de explantes tão pequenos como os ápices e os meristemas, também permite o estabelecimento de culturas com baixíssimo índice de perdas por contaminação e possibilita a eliminação de outros patógenos, como viróides, organismos semelhantes a micoplasmas e bactérias (Barlass, 1987).

A cultura de ápices fragmentados de videira foi inicialmente descrita por Barlass \& Skene (1978), para o cultivar Cabernet Sauvignon. Os autores obtiveram estruturas semelhantes a folhas a partir de fragmentos do ápice meristemático, retirado com 2 a 3 primórdios foliares e cerca de $1 \mathrm{~mm}$ de comprimento. Nestas estruturas houve a proliferação de uma grande quantidade de brotações.

Posteriormente, Barlass \& Skene (1980a) aprimoraram a técnica através do cultivo individual dos fragmentos em gotas de meio líquido, 
com aproximadamente $0,05 \mathrm{ml}$, sendo adicionados progressivamente volumes maiores de meio de cultura, até a transferência para o meio sólido, após 14 dias.

Estudos anatômicos revelaram que aquelas estruturas semelhantes a folhas foram regeneradas diretamente das células dos primórdios foliares, sem a formação de calos (Barlass \& Skene, 1980a) e a formação de gemas a partir destas folhas teve origem adventícia (Barlass et al., 1981).

Este método apresentou-se promissor para a multiplicação de videiras em larga escala, pois obtiveram-se aproximadamente 8.000 plantas em 4 meses, a partir de apenas um ápice (Barlass \& Skene, 1978), já sendo testada em diversos cultivares (Skene \& Barlass, 1980), além de possibilitar a limpeza de vírus, quando em conjunto com a termoterapia (Barlass, 1987; Barlass et al., 1982).

A micropropagação também tornou-se uma alternativa viável, para a multiplicação de videiras muscadíneas. Os cultivares da espécie Vitis rotundifolia apresentam grande interesse para o melhoramento de plantas, principalmente para a transferência de genes de resistência à pragas e doenças. Entretanto, sua propagação através de estacas lenhosas é muito difícil, mesmo com a aplicação exógena de auxina (Goode Junior et al., 1982). Mas com a micropropagação, já foi possível realizar a multiplicação de diversos cultivares, tais como, Carlos, Dixie, Fry, Jumbo, Magnolia, Noble, Regale, Sterling, Summit, Tarheel, Triumph e Welder (Gray \& Benton, 1990; Gray \& Fisher, 1985; Lee \& Wetzstein, 1990; Robacker \& Chang, 1992; Sudarsono \& Goldy, 1991; Thies \& Graves Junior, 1992; Wetzstein \& Myers, 1994). 


\subsubsection{Fonte de explantes}

Para a micropropagação de videira, duas fontes básicas de explantes são utilizadas: brotações obtidas de estacas ou coletadas diretamente do campo durante o período de crescimento (Krul \& Mowbray, 1984).

A utilização de matrizes a campo não se apresenta adequada, pois perde-se grande parte dos explantes por necrose, em poucos dias após o isolamento (Fanizza et al., 1984). Isto ocorre devido ao elevado conteúdo de substâncias fenólicas presentes nos ramos, que oxidam in vitro, causando a morte dos explantes. Explantes retirados de ramos localizados em regiões sombreadas da planta apresentam maior sobrevivência do que os retirados de ramos a pleno sol, já que a síntese de compostos fenólicos aumenta com a intensidade luminosa (Yu \& Meredith, 1986).

Os explantes provenientes do campo também são mais difíceis de serem desinfestados, resultando sempre em maior perda de material por contaminação em relação aos obtidos de ambientes protegidos (Reustle et al., 1988).

Um método para a obtenção de brotações a partir de estacas lenhosas foi descrito por Goussard (1981), e baseia-se na coleta de estacas com $40 \mathrm{~cm}$ de comprimento durante o inverno, tratamento com captan $(2 \%)$ e armazenamento em sacos plásticos a 2 ou $3^{\circ} \mathrm{C}$. Quando há necessidade de explantes, retiram-se as estacas da câmara fria e cortam-se as mesmas em segmentos de 12 a $15 \mathrm{~cm}$, com 3 gemas, colocando-as para brotar em recipientes com $80 \mathrm{ml}$ de água, a uma temperatura ambiente de 28 a $30^{\circ} \mathrm{C}$ e com iluminação constante. Outros métodos semelhantes também foram utilizados, armazenando-se as estacas em sacos plásticos em temperaturas 
de 4 a $7^{\circ} \mathrm{C}$ e promovendo a brotação de estacas com apenas uma gema em água, nas mesmas condições de incubação das culturas micropropagadas (Chée \& Pool, 1983; Dalal et al., 1992; Mullins et al., 1979).

Este procedimento possibilita a obtenção de grande quantidade de material vegetal homogêneo numa pequena área, durante 0 ano todo, conforme observado por Passos (1991) que realizou uma série de estudos com diversas substâncias adicionadas ao substrato da estaca, tais como 6benzilaminopurina, cianamida hidrogenada, calciocianamida, ácido giberélico e ácido naftalenoacético, chegando à conclusão de que estes produtos não proporcionaram a obtenção de melhores resultados de brotação, do que apenas a utilização de água. Entretanto, para uma brotação rápida e homogênea, recomenda-se a utilização de estacas estocadas a frio e com área transversal média de $59,5 \mathrm{~mm}^{2}$ ou $1,2 \mathrm{~cm}$ de diâmetro.

A partir das brotações retiram-se os explantes que normalmente são segmentos nodais (Gribaudo \& Fronda, 1991), ápices meristemáticos (Yu \& Meredith, 1986) ou meristemas (Passos et al., 1985).

Os segmentos nodais constituem-se de micro-estacas com apenas 1 gema lateral mais uma pequena porção dos tecidos adjacentes do caule e pecíolo, variando de 0,8 a $2,5 \mathrm{~cm}$ de comprimento (Gribaudo \& Fronda, 1991; Martinez \& Tizio, 1989; Mullins et al., 1979).

Os ápices meristemáticos são retirados da extremidade apical das brotações com cerca de 2 a 4 primórdios foliares e 0,5 a $1,5 \mathrm{~mm}$ de comprimento (Botti et al., 1993; Chée \& Pool, 1982; Goussard, 1981), 
sendo cortados em pedaços menores, quando realizada a cultura de ápices fragmentados (Barlass \& Skene, 1978).

Os meristemas também são retirados da extremidade das brotações, mas possuem um tamanho menor do que os ápices, atingindo no máximo 0,5mm de comprimento (Troncoso et al., 1988; Novák \& Juvová, 1983) com 1 ou 2 primórdios foliares (Passos et al., 1985). Meristemas menores do que $0,3 \mathrm{~mm}$ dificilmente regeneram novas plantas (Koruza \& Jelaska, 1993).

\subsubsection{Assepsia}

Os produtos geralmente utilizados para a desinfestação dos explantes são o hipoclorito de sódio (Goussard, 1981; Passos et al., 1985), hipoclorito de cálcio (Bass et al., 1988; Fanizza et al., 1984), álcool (Harris \& Stevenson, 1982; Martinez \& Tizio, 1989), cloreto de benzalcônio (Yu \& Meredith, 1986) e cloreto de mercúrio (Dalal et al., 1992).

Os diversos procedimentos utilizados, para a assepsia das brotações de videiras e os tipos de explantes retirados, podem ser observados na Tabela 1.

\subsubsection{Cultura inicial}

Após a assepsia, os explantes estão prontos para serem inoculados no meio de cultura, mas dificilmente o procedimento utilizado é completamente eficiente e muitos explantes podem ser perdidos pelo desenvolvimento de microorganismos ou oxidação (Fanizza et al., 1984; 
TABELA 1. Procedimentos de assepsia e tipos de explantes utilizados na micropropagação de videiras.

\begin{tabular}{|c|c|c|}
\hline $\begin{array}{l}\text { TIPO DE } \\
\text { EXPLANTE }\end{array}$ & ASSEPSIA & AUTOR \\
\hline $\begin{array}{l}\text { Meristemas } \\
(0,1-0,2 \mathrm{~mm})\end{array}$ & $\mathrm{NaOCl} 0,25 \%(5 \mathrm{~min})$ & Duran-Vila et al. (1988) \\
\hline $\begin{array}{l}\text { Meristemas } \\
(0,2-0,4 \mathrm{~mm})\end{array}$ & $\begin{array}{l}\mathrm{NaOCl} 1 \%+\text { Tween } 200,05 \% \\
\text { (3min) }\end{array}$ & Thies \& Graves Junior (1992) \\
\hline $\begin{array}{l}\text { Meristemas } \\
(0,3-0,6 \mathrm{~mm})\end{array}$ & $\begin{array}{l}\text { Etanol } 70 \%(10 \text { seg }) \text { e } \mathrm{NaOCl} \\
1 \%(10 \mathrm{~min})\end{array}$ & Blazina et al. (199 lb) \\
\hline $\begin{array}{l}\text { Meristemas } \\
(0,5 \mathrm{~mm})\end{array}$ & $\begin{array}{l}\text { Cloramina B } 8 \%(30 \mathrm{~min}) \text { e } \\
\text { etanol } 70 \% \text { (lavagem) }\end{array}$ & Novák \& Juvová (1983) \\
\hline $\begin{array}{l}\text { Meristemas } \\
\text { ( } 2 \text { primórdios) }\end{array}$ & $\begin{array}{l}\text { Solução comercial de } \mathrm{NaOCl} \text { a } \\
20 \% \text { (20min) }\end{array}$ & Passos et al. (1985) \\
\hline $\begin{array}{l}\text { Ápices } \\
\text { fragmentados } \\
(1 \mathrm{~mm})\end{array}$ & $\begin{array}{l}\mathrm{CaOCl} 5 \%+\text { Tween } 200,01 \% \\
(15 \mathrm{~min})\end{array}$ & $\begin{array}{l}\text { Barlass \& Skene (1978); } \\
\text { Barlass \& Skene (1980a); } \\
\text { Skene \& Barlass, (1980) }\end{array}$ \\
\hline $\begin{array}{l}\text { Ápices } \\
\text { fragmentados } \\
(4-5 \mathrm{~mm})\end{array}$ & $\mathrm{NaOCl} 1 \%(20 \mathrm{~min})$ & Robacker \& Chang (1992) \\
\hline Ápices $(0,5 \mathrm{~mm})$ & $\begin{array}{l}\text { Etanol } 70 \%(15 \mathrm{seg}) \text { e } \mathrm{NaOCl} \\
0,5 \%(30 \mathrm{~min})\end{array}$ & Troncoso et al. (1988) \\
\hline Ápices $(0,5-1 \mathrm{~mm})$ & $\begin{array}{l}\mathrm{NaOCl} 1,2 \%+\text { Tween } 200,1 \% \\
(10 \mathrm{~min})\end{array}$ & Chée \& Pool (1982) \\
\hline Ápices $(0,7-1 \mathrm{~mm})$ & $\begin{array}{l}\mathrm{NaOCl} 1,3 \%+\text { Tween } 200,1 \% \\
\text { (10min) }\end{array}$ & Li \& Eaton (1984) \\
\hline $\begin{array}{l}\text { Ápices } \\
(0,75-1 \mathrm{~mm})\end{array}$ & $\mathrm{NaOCl} 0,5 \%(10 \mathrm{~min})$ & Goussard (1981) \\
\hline Ápices (lmm) & $\mathrm{CaOCl} 5 \%$ (20min) & Fanizza et al. (1988) \\
\hline Ápices (lmm) & $\begin{array}{l}\mathrm{NaOCl} 1,3 \%+\text { Triton } X(2,5 \mathrm{a} \\
3 \mathrm{~min})\end{array}$ & Gray \& Benton (1991) \\
\hline
\end{tabular}

continua... 
continua...

TABELA 1. Procedimentos de assepsia e tipos de explantes utilizados na micropropagação de videiras.

\begin{tabular}{|c|c|c|}
\hline $\begin{array}{l}\text { TIPO DE } \\
\text { EXPLANTE }\end{array}$ & ASSEPSIA & AUTOR \\
\hline Ápices (1 mm) & $\begin{array}{l}\text { Cloreto de benzolcônio } 17 \% \\
\text { diluido } 1: 22,5 \text { (15 a } 18 \mathrm{~min})\end{array}$ & Yu \& Meredith (1986) \\
\hline Ápices (1mm) & $\mathrm{CaOCl} 5 \%(15 \mathrm{~min})$ & Fanizza et al. (1984) \\
\hline Ápices (1-2mm) & $\begin{array}{l}\text { Solução comercial de } \mathrm{NaOCl} \text { a } \\
25 \%+\text { Triton } \mathrm{X}(3 \mathrm{~min})\end{array}$ & Gray \& Fisher (1985) \\
\hline Ápices (3-8mm) & $\begin{array}{l}\text { Álcool } 70 \% \text { ( } 1 \mathrm{~min}) \text { ou solução } \\
\text { comercial com } 12 \% \text { de } \\
\text { hipoclorito a } 7 \%+\text { Tween } 20 \\
0,1 \%(20 \mathrm{~min})\end{array}$ & Harris \& Stevenson (1982) \\
\hline Ápices $(10 \mathrm{~mm})$ & $\begin{array}{l}\text { Cloreto de mercúrio } 0,1 \% \\
(6 \mathrm{~min})\end{array}$ & Dalal et al. (1992) \\
\hline $\begin{array}{l}\text { Segmentos nodais } \\
(3 \mathrm{~mm})\end{array}$ & $\begin{array}{l}\mathrm{NaOCl} 1,3 \%(25 \mathrm{~min}) \text { e } \mathrm{NaOCl} \\
0,7 \%(10 \mathrm{~min})\end{array}$ & Sudarsono \& Goldy (1991) \\
\hline $\begin{array}{l}\text { Segmentos nodais } \\
(0,8 \mathrm{~cm})\end{array}$ & $\begin{array}{l}\text { Solução comercial com } 7 \% \text { de } \\
\text { cloro a } 25 \%(15 \mathrm{~min})\end{array}$ & Gribaudo \& Fronda (1991) \\
\hline $\begin{array}{l}\text { Segmentos nodais } \\
(0,5-1 \mathrm{~cm})\end{array}$ & $\begin{array}{l}\text { Água corrente }(30 \mathrm{~min}) \mathrm{e} \\
\mathrm{CaOCl} 2 \%+\text { Tween } 200,1 \%\end{array}$ & Lee \& Wetzstein (1990) \\
\hline $\begin{array}{l}\text { Segmentos nodais } \\
(1 \mathrm{~cm})\end{array}$ & $\begin{array}{l}\mathrm{NaOCl} 1 \%+\text { Tween } 200,1 \% \\
(15 \mathrm{~min})\end{array}$ & Mullins et al. (1979) \\
\hline $\begin{array}{l}\text { Segmentos nodais } \\
(1,5 \mathrm{~cm})\end{array}$ & $\begin{array}{l}\text { Etanol } 95 \%(15 \mathrm{seg}) \text { e } \mathrm{NaOCl} \\
0,78 \%+\text { Tween } 200,1 \% \\
(20 \mathrm{~min})\end{array}$ & Lewandowski (1991) \\
\hline $\begin{array}{l}\text { Segmentos nodais } \\
(1 \mathrm{a} 2 \mathrm{~cm})\end{array}$ & $\begin{array}{l}\text { Etanol } 70 \%(3 \mathrm{~min}) \text { e } \mathrm{CaOCl} \\
3 \%+\text { Tween } 200,1 \%(10 \mathrm{~min})\end{array}$ & $\begin{array}{l}\text { Roubelakis-Angelakis \& } \\
\text { Zivanovitc (1991) }\end{array}$ \\
\hline $\begin{array}{l}\text { Segmentos nodais } \\
(2,5 \pm 0,5 \mathrm{~cm})\end{array}$ & $\begin{array}{l}\text { Etanol } 75 \%(3 \mathrm{~min}) \text { e } \mathrm{NaOCl} \\
15 \%+\text { Tween } 200,1 \%(15 \mathrm{~min})\end{array}$ & Martinez \& Tizio (1989) \\
\hline
\end{tabular}


Reustle et al., 1988). Neste sentido, pode-se fazer um précondicionamento, inoculando os explantes em meio nutritivo sem reguladores, transferindo para novos meios, após uma semana, apenas aqueles sadios e viáveis (Passos et al., 1985).

O meio de pré-incubação utilizado para videira por Passos et al. (1985) constou da metade da concentração dos macronutrientes do meio MS (Murashige \& Skoog, 1962) e dos micronutrientes do meio NN (Nitsch \& Nitsch, 1969), vitaminas do meio $\mathrm{NN}, 1 \mathrm{mg} / \mathrm{L}$ de inositol, 0,8mg/L de cisteína, 30g/L de sacarose, 4g/L de carvão ativado e $7 \mathrm{~g} / \mathrm{L}$ de ágar. Os explantes viáveis são transferidos para o meio de cultura inicial onde freqüentemente adicionam-se reguladores com o objetivo de suprir as possíveis deficiências nos teores endógenos de hormônios.

O regulador de crescimento mais utilizado e mais efetivo é a 6benzilaminopurina (BAP) em concentrações variáveis, dependendo do cultivar e do tipo de explante utilizado (Bass et al., 1988; Botti et al., 1993; Blazina et al., 1991b; Gray \& Fisher, 1985).

Novák \& Juvová (1983) comprovaram que BAP foi a citocinina mais eficiente, sụperior à cinetina e à 2-isopenteniladenina (2iP), para estimular o crescimento de meristemas $(0,5 \mathrm{~mm})$ e a proliferação de novas brotações em 8 clones de videira. A concentração de $10 \mu \mathrm{M}$ de BAP em meio MS, estimulou o crescimento de meristemas axilares 20 dias após o isolamento, ocasionando a formação de múltiplas brotações. Diversos autores também observaram a superioridade de BAP em relação a outras citocininas (Barlass \& Skene, 1980b; Goussard, 1982; Gray \& Benton, 1990). 
Para o cultivar A Dona, as concentrações de 2 e $5 \mu \mathrm{M}$ de BAP em meio básico $\mathrm{NN}$, foram as mais apropriadas para o desenvolvimento e diferenciação de meristemas com um ou dois primórdios foliares (Passos et al., 1985).

Chée \& Pool (1983) trabalhando com 21 genótipos de videira utilizaram para a fase de estabelecimento inicial o meio de cultura MS com $3 \mu \mathrm{M}$ de tiamina, $55,5 \mu \mathrm{M}$ de mio-inositol, $8 \mu \mathrm{M}$ de ácido nicotínico, $5 \mu \mathrm{M}$ de piridoxina, $5 \mu \mathrm{M}$ de BAP, 0,5 de ANA, $3 \%$ de sacarose e $0,8 \%$ de ágar.

Para o híbrido 'Baco', Harris \& Stevenson (1982) encontraram os melhores resultados nesta fase cultivando ápices de 3 a $8 \mathrm{~mm}$ em meio MS com $0,4 \mathrm{mg} / \mathrm{L}$ de tiamina, $100 \mathrm{mg} / \mathrm{L}$ de inositol, $30 \mathrm{~g} / \mathrm{L}$ de sacarose, $80 \mathrm{mg} / \mathrm{L}$ de adenina, $170 \mathrm{mg} / \mathrm{L}$ de fosfato de sódio monobásico e $3 \mathrm{mg} / \mathrm{L}$ de BAP. Os autores também utilizaram este meio para micropropagar outros 21 genótipos de videira, reduzindo o concentração de BAP para $2 \mathrm{mg} / \mathrm{L}$.

Para os cultivares Ribier, Thompson Seedless e Black Seedless, Botti et al. (1993) isolando ápices com 0,5 a 1,5mm, utilizaram para a fase inicial o meio MS com $3 / 4$ de sua concentração normal mais $2 \mathrm{mg} / \mathrm{L}$ de BAP.

O meio de cultura mais utilizado nos trabalhos com a micropropagação de videiras é o MS. Muitas modificações na sua composição já foram sugeridas por diversos autores, principalmente alterações nos constituintes orgânicos (Chée \& Pool, 1985; Harris \& Stevenson, 1982; Lewandowski, 1991) e reduções na concentração dos macro e micronutrientes (Blazina et al., 1991a; Botti et al., 1993; Fanizza et al., 1984). 
Além do MS, outros meios de cultura foram utilizados para a micropropagação de videiras, como o NN, o WPM (Lloyd \& McCown, 1986), o $C_{2} \mathrm{D}$ (Chée \& Pool, 1983) e o Galzy (Galzy, 1964) que foi posteriormente modificado pelo mesmo autor (Galzy, 1990).

Os meios de indução geralmente incluem ágar na concentração de 6 a $8 \mathrm{~g} / \mathrm{L}$, mas na cultura de ápices fragmentados o isolamento inicial é realizado em meio MS líquido suplementado com $10 \mu \mathrm{M}$ de BAP (Barlass \& Skene, 1980b).

O comportamento dos explantes de videiras muscadíneas é semelhante ao dos demais cultivares, respondendo melhor à adição de BAP em meio de cultura MS, em concentrações próximas de $10 \mu \mathrm{M}$ (Gray \& Benton, 1990; Lee \& Wetzstein, 1990; Thies \& Graves Junior, 1992).

\subsubsection{Multiplicação}

A rápida multiplicação de clones livres de vírus possue grande importância comercial, sendo obtidos bons resultados através da micropropagação (Krul \& Mowbray, 1984). A partir de um explante, Botti et al. (1993) estimaram a obtenção anual de 2.808 .990 brotações do cultivar Thompson Seedless, 26.494 brotações do Ribier e 1.213 do Black Seedless em meio MS com $2 \mathrm{mg} / \mathrm{L}$ de BAP.

$\mathrm{Na}$ cultura de ápices fragmentados, Barlass \& Skene (1978) estimaram a produção de aproximadamente 8.000 plantas em 4 meses.

Harris \& Stevenson (1982) estabeleceram um protocolo capaz de produzir 12.000 brotações em 4 meses, a partir de apenas um ápice meristemático. Após a fase inicial, os autores transferiram os explantes 
para meio MS líquido com $3 / 4$ de sua concentração normal, suplementado com $170 \mathrm{mg} / \mathrm{L}$ de fosfato de sódio monobásico, $80 \mathrm{mg} / \mathrm{L}$ de adenina e $3 \mathrm{mg} / \mathrm{L}$ de BAP. A cada 2 a 3 semanas foi realizada a repicagem até os brotos iniciarem a alongação, reduzindo-se a concentração de BAP para $2 \mathrm{mg} / \mathrm{L}$ e o intervalo de repicagem para 2 semanas.

Lewandowski (1991) obteve cerca de 3.000 plantas de videira 'Delaware' por mês, utilizando um meio MS modificado e reduzindo os intervalos de repicagem, mas ressaltou a importância de novos isolamentos anualmente, em combinação com uma proliferação limitada de brotações, para reduzir o risco da variação somaclonal.

Para a contínua multiplicação de brotações é necessária a adição de citocinina ao meio de cultura, mas geralmente a concentração utilizada na fase de indução é suficiente para permitir o crescimento contínuo das brotações (Krul \& Mowbray, 1984). A subcultura repetida em meio com citocinina pode inibir o crescimento das brotações (Koruza \& Jelaska, 1993) e concentrações muito elevadas de citocinina também são prejudiciais, causando a formação de brotações anormais e vitrificadas (Chée \& Pool, 1985; Harris \& Stevenson, 1982; Lee \& Wetzstein, 1990).

$\mathrm{Na}$ micropropagação do cultivar Summit, a melhor produção de brotos foi encontrada com a adição de $10 \mu \mathrm{M}$ de BAP, enquanto concentrações superiores a $20 \mu \mathrm{M}$ causaram redução na proliferação e crescimento dos brotos, com altos índices de mortalidade. Brotações cultivadas em meio com $5 \mu \mathrm{M}$ de BAP enraizaram melhor do que aquelas provenientes de meios com $10 \mu \mathrm{M}$ do mesmo regulador (Lee \& Wetzstein, 1990). 
As maiores taxas de multiplicação de brotações do porta-enxerto '1103 Paulsen' foram obtidas por Peixoto et al. (1994) com 0,5 e 1mg/L de BAP, mas para a obtenção de brotações maiores do que $1 \mathrm{~cm}$, a concentração de $0,5 \mathrm{mg} / \mathrm{L}$ foi a melhor. Concentrações maiores do que esta aumentaram a vitrificação das brotações.

O uso de BAP em combinação com zeatina, ambos na concentração de $2 \mathrm{mg} / \mathrm{L}$, promoveu a obtenção do melhor resultado de multiplicação (14,3 brotos/explante) para o cultivar Chenin Blanc, sendo que a concentração de $5 \mathrm{mg} / \mathrm{L}$ de BAP foi extremamente prejudicial (Goussard, 1981). Entretanto, para o mesmo cultivar, o uso de $10 \mathrm{mg} / \mathrm{L}$ de zeatina proporcionou o desenvolvimento de brotações de melhor qualidade do que as obtidas com a combinação de BAP e zeatina (Goussard, 1982).

$\mathrm{O}$ thidiazuron, uma feniluréia, possue efeito de citocinina mesmo em baixas concentrações, conforme verificaram Gribaudo \& Fronda (1991) para o cultivar Barbera. Entretanto, em concentrações superiores a $0,1 \mu \mathrm{M}$ ele provocou sintomas de vitrificação, com folhas mal formadas e engrossamento das brotações, também sendo prejudicial para 0 enraizamento, inibindo-o totalmente na concentração de $1 \mu \mathrm{M}$. Gray \& Benton (1990), trabalhando com cultivares muscadíneas, também verificaram que apesar do thidiazuron produzir o mesmo número de brotações do que o BAP, aquelas foram atrofiadas e tortas e apresentaram dificuldade de enraizamento.

Chée \& Pool (1985) após testarem diversas concentrações de várias substâncias orgânicas no meio básico de MS, obtiveram a melhor multiplicação de brotações do cultivar Remaily Seedless com $3 \mu \mathrm{M}$ de 
tiamina, $55,5 \mu \mathrm{M}$ de mio-inositol, $8 \mu \mathrm{M}$ de ácido nicotínico e $5 \mu \mathrm{M}$ de piridoxina, sendo que os aminoácidos arginina, asparagina, glutamina e tirosina, em concentrações de 0,25 até $4 \mathrm{mM}$, não tiveram efeito sobre a multiplicação.

O iodo, que não é um elemento essencial para as plantas superiores, segundo Chée \& Pool (1987), pode ser retirado dos meios de cultura. Estes autores verificaram que o efeito do KI na produção de brotações também foi obtido com $\mathrm{MnSO}_{4}$ e sugeriram a hipótese de que, como o $\mathrm{KI}$ inibe o transporte de AIA e o manganês inibe a oxidação do AIA, concentrações menores de manganês ou KI poderiam reduzir o conteúdo de auxina endógena, resultando talvez em menor inibição do crescimento de gemas axilares.

Para diversos cultivares de videiras muscadíneas, Gray \& Benton (1991) verificaram que o meio de cultura WPM provocou a ocorrência de vitrificação e abscisão foliar nas brotações, e os meios $\mathrm{MS}$ e $\mathrm{C}_{2} \mathrm{D}$ resultaram em taxas equivalentes de multiplicação.

\subsubsection{Enraizamento}

A maioria dos cultivares de videira micropropagados enraizam facilmente, sendo em geral suficiente apenas a transferência para um meio isento de reguladores de crescimento (Krul \& Mowbray, 1984). O enraizamento pode ser realizado em meio solidificado com ágar (Chée \& Pool, 1988; Martinez \& Tizio, 1989; Novák \& Juvová, 1983), em meio líquido com suporte de papel de filtro ou diretamente em recipientes in vivo (Harris \& Stevenson, 1982). 
O enraizamento de 'Moscato d'Amburgo' e 'Pinot Bianco' foi obtido com sucesso por Ciccotti (1982) em meio MS com a metade da concentração de sais sem auxinas, mas adicionado de $0,3 \mathrm{mg} / \mathrm{L}$ de tiamina.

O uso de meios mais diluídos e com menor concentração de sacarose, mostraram-se mais adequados para o enraizamento (Harris \& Stevenson, 1982). A redução de $3 \%$ para $1 \%$ no conteúdo de sacarose do meio MS promoveu o melhor crescimento das brotações da videira 'Remaily Seedless' e este aumento de vigor foi associado por Chée \& Pool (1988) como causa provável da melhoria no enraizamento. No meio com $3 \%$ de sacarose, mesmo com a adição de $1,6 \mu \mathrm{M}$ de ANA, as brotações enraizaram pouco e com raízes de baixa qualidade, formando plantas inadequadas para a aclimatização.

As auxinas mais utilizadas são o AIB (Botti et al., 1993; Lee \& Wetzstein, 1990; Lewandowski, 1991) e o ANA (Chée \& Pool, 1982; Chée \& Pool, 1983; Chée \& Pool, 1988; Martinez \& Tizio, 1989).

Há uma forte influência do genótipo sobre a capacidade de enraizamento, ocorrendo diferenças entre espécies e entre cultivares da mesma espécie (Chée \& Pool, 1983). No trabalho realizado por Roubelakis-Angelakis \& Zivanovitc (1991), de quinze cultivares estudados, sete não enraizaram em meio $\mathrm{MS}$ sem $\mathrm{AIB}$, mas todos enraizaram num meio MS modificado pelos autores, mesmo sem AIB, com exceção dos cultivares Liatiko e SO4, cujo enraizamento foi baixo em ambos os meios. A concentração ótima de AIB para os cultivares de Vitis vinifera foi de 3 a $5 \mu \mathrm{M}$. 
A adição de $0,1 \mathrm{mg} / \mathrm{L}$ de ANA foi necessária para induzir a rizogênese em 'Thompson Seedless', 'Muscat of Alexandria', 'Dorradillo', 'Concord', 'Ramsey', 'Dog Ridge', 'Rupestris du Lot', 'R-99', '1613' e 'Harmony', mas para 'Cabernet Sauvignon' e 'Cabernet Franc' apenas a cultura em meio White isento de reguladores foi suficiente (Barlass \& Skene, 1980b; Skene \& Barlass, 1980).

$\mathrm{O}$ uso de $1 \mathrm{~g} / \mathrm{L}$ de carvão ativado, não proporcionou aumento no enraizamento de alguns clones de videira utilizados no trabalho realizado por Novák \& Juvová (1983), chegando até mesmo a reduzir o efeito da adição de auxinas. Neste trabalho a adição de $0,1 \mu \mathrm{M}$ de ANA ou AIB, em meio MS com a concentração reduzida pela metade, foi eficiente na promoção do enraizamento, resultando em valores superiores a $\mathbf{9 0 \%}$. O ANA estimulou também a formação de calos na base das brotações, o que não ocorreu com o uso de AIB, onde as raízes formaram-se diretamente das brotações.

Para o enraizamento dos porta-enxertos '1103 Paulsen' e 'RR 10114', a dosagem de $0,02 \mathrm{mg} / \mathrm{L}$ de ANA foi a mais efetiva, sendo que dosagens superiores não promoveram aumentos no crescimento radicular e no número de raízes, além de aumentarem a proliferação de calos (Peixoto et al., 1994).

O pré-tratamento de imersão em solução de AIB por 15 minutos, nas respectivas concentrações de $2,46 \mathrm{mM}$ e $3,94 \mathrm{mM}$, evitou a formação de calos em brotações dos cultivares Marechal Foch e Cascade e promoveu o melhor enraizamento em meio MS com metade da concentração de sais (Li \& Eaton, 1984). 
A utilização conjunta de AIB e ANA causou um efeito sinérgico no enraizamento da videira 'Delaware', sendo $1 \mathrm{~g} / \mathrm{L}$ de ANA e $5 \mathrm{~g} / \mathrm{L}$ de AIB a melhor combinação, proporcionando um efeito claramente superior aos efeitos individuais dos reguladores, o que resultou em mais de $95 \%$ de brotações enraizadas (Lewandowski, 1991).

O enraizamento direto das brotações em recipientes durante a fase de aclimatização, tem apresentado bons resultados para diversos cultivares. Este processo é mais eficiente do que o enraizamento in vitro, porque elimina uma etapa da micropropagação e resulta em plantas mais vigorosas em menor tempo (Gray \& Benton, 1990; Gray \& Benton, 1991).

Com o enraizamento in vivo, em substrato formado de perlita e sob nebulização, foi possível elevar a sobrevivência após o transplante do cultivar Palomino Fino, obtendo-se até $83 \%$ de plantas enraizadas (Troncoso et al., 1988).

Substratos à base de turfa e solo, ou adicionados de solução nutritiva com sacarose, não são adequados para o enraizamento direto, pela freqüente contaminação com fungos e algas. A utilização de perlita e vermiculita também requer cuidados, pois o excesso de umidade pode ocasionar o enraizamento superficial das brotações, indicando a falta de aeração do substrato, conforme observaram Harris \& Stevenson (1982) com o cultivar Baco. Estes autores também obtiveram em câmara de nebulização resultados semelhantes ao enraizamento in vitro, com a utilização de perlita grossa, saturada do meio MS modificado com 1/4 de sua concentração, adicionado de $0,1 \mathrm{mg} / \mathrm{L}$ de AIA e sem sacarose. 
O pré-tratamento com Rootone-F, um produto comercial à base de auxinas, antes do transplante direto, aumentou o número de raízes emitidas por brotação de alguns cultivares de Vitis rotundifolia, mas não afetou a porcentagem de enraizamento que, apesar de ter sido inferior a obtida in vitro, proporcionou a formação de plantas mais vigorosas (Gray \& Benton, 1991).

\subsubsection{Aclimatização}

A aclimatização em câmaras de nebulização constitue-se na forma mais utilizada para amenizar o estresse hídrico das plantas ocasionado pela saída dos frascos de cultura. Nas primeiras semanas após o transplante, a umidade relativa do ar deve permanecer alta, pois a perda de água pelas folhas formadas in vitro é elevada, até que a atividade estomática seja regularizada e aumente a camada de cutícula sobre as folhas (Lewandowski, 1991).

A taxa de sobrevivência da videira em condição de nebulização é alta, sendo freqüentemente obtidos resultados acima de $90 \%$ em diversos cultivares (Blazina et al., 1991b; Galzy, 1964; Lewandowski, 1991).

Os substratos utilizados são bastante variados, incluindo solo, perlita, vermiculita, turfa, areia e diversas misturas comerciais (Blazina et al., 1991b; Gray \& Benton, 1991; Harris \& Stevenson, 1982; Thies \& Graves Junior, 1992; Troncoso et al., 1988). A inclusão de nutrientes ao substrato, através de adubos e soluções nutritivas, auxilia o crescimento das plantas micropropagadas (Chée \& Pool, 1982; Lewandowski, 1991). 


\subsubsection{Condições de crescimento}

As condições de ambiente em que as culturas de videira são mantidas apresentam variações entre os trabalhos realizados por diversos autores, principalmente quanto à intensidade luminosa, devido às condições específicas de cada laboratório, como pode-se observar na Tabela 2.

A temperatura determina a velocidade de crescimento das culturas (Galzy \& Compan, 1988). Ápices fragmentados do cultivar Cabernet Sauvignon, quando mantidos com temperatura de $27^{\circ} \mathrm{C}$ durante o período de luz e $20^{\circ} \mathrm{C}$ no escuro, levaram 31 dias para iniciar o crescimento das brotações, enquanto na temperatura constante de $35^{\circ} \mathrm{C}$, a multiplicação já ocorreu aos 18 dias (Barlass et al., 1981).

Para o enraizamento de diversos cultivares de videira, a melhor temperatura encontrada por Fanizza et al. (1988) foi de $32^{\circ} \mathrm{C}$.

As videiras podem se adaptar, dentro de certos limites, as condições de crescimento, conforme verificaram Galzy et al. (1990) com os cultivares Rupestris du Lot, Chardonnay e Pinot Noir. Na temperatura de $21^{\circ} \mathrm{C}$ e intensidade luminosa de $40 \mu \mathrm{mol} / \mathrm{m}^{2} \mathrm{~s}$, o genótipo e as condições de crescimento influenciaram no crescimento das plantas, mas o peso da matéria seca permaneceu estável. Já na temperatura de $12^{\circ} \mathrm{C}$ e $12 \mu \mathrm{mol} / \mathrm{m}^{2} \mathrm{~s}$ ocorreu um aumento no conteúdo de matéria seca. Segundo os autores, isto sugere que o requerimento nutricional in vitro não é apenas uma característica varietal, mas também está relacionada com as condições físicas de crescimento. 
TABELA 2. Condições de temperatura, fotoperíodo e intensidade luminosa utilizados para a micropropagação de videiras.

\begin{tabular}{|c|c|c|c|}
\hline TEMPERATURA & $\begin{array}{c}\text { FOTO- } \\
\text { PERÍODO } \\
\end{array}$ & $\begin{array}{c}\text { INTENSIDADE } \\
\text { LUMINOSA }\end{array}$ & AUTOR \\
\hline $28 \pm 2^{\circ} \mathrm{C}$ & $18 \mathrm{~h}$ & $25 \pm 3 \mu \mathrm{mol} / \mathrm{m}^{2} \mathrm{~s}$ & $\begin{array}{l}\text { Thies \& Graves Junior } \\
\text { (1992) }\end{array}$ \\
\hline $25^{\circ} \mathrm{C}$ & $18 \mathrm{~h}$ & $60 \mu \mathrm{mol} / \mathrm{m}^{2} \mathrm{~s}$ & Gray \& Benton (1991) \\
\hline $21-25^{\circ} \mathrm{C}$ & $18 \mathrm{~h}$ & - & Gray \& Fisher (1985) \\
\hline $27-30^{\circ} \mathrm{C}$ & $16 \mathrm{~h}$ & $70 \mu \mathrm{mol} / \mathrm{m}^{2} \mathrm{~s}$ & Robacker \& Chang (1992) \\
\hline $25 \pm 2^{\circ} \mathrm{C}$ & $16 \mathrm{~h}$ & $68 \mu \mathrm{mol} / \mathrm{m}^{2} \mathrm{~s}$ & Lee \& Wetzstein (1990) \\
\hline $25-26^{\circ} \mathrm{C}$ & $16 \mathrm{~h}$ & $50-70 \mu \mathrm{mol} / \mathrm{m}^{2} \mathrm{~s}$ & Yu \& Meredith (1986) \\
\hline $\begin{array}{l}26^{\circ} \mathrm{C} \text { luz } \\
20^{\circ} \mathrm{C} \text { escuro }\end{array}$ & $16 \mathrm{~h}$ & $52 \mu \mathrm{mol} / \mathrm{m}^{2} \mathrm{~s}$ & Lewandowski (1991) \\
\hline $25 \pm 1^{\circ} \mathrm{C}$ & $16 \mathrm{~h}$ & $50 \mu \mathrm{mol} / \mathrm{m}^{2} \mathrm{~s}$ & $\begin{array}{l}\text { Roubelakis-Angelakis \& } \\
\text { Zivanovitc (1991) }\end{array}$ \\
\hline $23^{\circ} \mathrm{C}$ & $16 \mathrm{~h}$ & $50 \mu \mathrm{mol} / \mathrm{m}^{2} \mathrm{~s}$ & Gribaudo \& Fronda (1991) \\
\hline $\begin{array}{l}28^{\circ} \mathrm{C} \text { luz } \\
25^{\circ} \mathrm{C} \text { escuro }\end{array}$ & $16 \mathrm{~h}$ & $\begin{array}{l}33,8 \text { a } 43,1 \\
\mu \mathrm{mol} / \mathrm{m}^{2} \mathrm{~s}\end{array}$ & Sudarsono \& Goldy (1991) \\
\hline $\begin{array}{l}32^{\circ} \mathrm{C} \text { luz } \\
28^{\circ} \mathrm{C} \text { escuro }\end{array}$ & $16 \mathrm{~h}$ & $250-300 \mu \mathrm{E} / \mathrm{m}^{2} \mathrm{~s}$ & Barlass et al. (1982) \\
\hline $25^{\circ} \mathrm{C}$ & $16 \mathrm{~h}$ & $50-100 \mu \mathrm{E} / \mathrm{m}^{2} \mathrm{~s}$ & $\begin{array}{l}\text { Blazina et al. (1991a); } \\
\text { Blazina et al. (1991b) }\end{array}$ \\
\hline $23 \pm 2^{\circ} \mathrm{C}$ & $16 \mathrm{~h}$ & 35 a $43 \mu \mathrm{E} / \mathrm{m}^{2} \mathrm{~s}$ & Harris \& Stevenson (1982) \\
\hline $25-27^{\circ} \mathrm{C}$ & $16 \mathrm{~h}$ & $35 \mu \mathrm{E} / \mathrm{m}^{2} \mathrm{~s}$ & Peixoto et al. (1994) \\
\hline $26 \pm 2^{\circ} \mathrm{C}$ & $16 \mathrm{~h}$ & $30 \mu \mathrm{E} / \mathrm{m}^{2} \mathrm{~s}$ & Botti et al. (1993) \\
\hline $26^{\circ} \mathrm{C}$ & $16 \mathrm{~h}$ & $2,5 \mathrm{~W} / \mathrm{m}^{2}$ & Mullins et al. (1979) \\
\hline
\end{tabular}


continua...

TABELA 2. Condições de temperatura, fotoperíodo e intensidade luminosa utilizados para a micropropagação de videiras.

\begin{tabular}{|c|c|c|c|}
\hline TEMPERATURA & $\begin{array}{c}\text { FOTO- } \\
\text { PERÍODO }\end{array}$ & $\begin{array}{c}\text { INTENSIDADE } \\
\text { LUMINOSA } \\
\end{array}$ & AUTOR \\
\hline- & $16 \mathrm{~h}$ & 3.600 lux & Novák \& Juvová (1983) \\
\hline $24 \pm 1^{\circ} \mathrm{C}$ & $16 \mathrm{~h}$ & $3.5001 u x$ & Dalal et al. (1992) \\
\hline $\begin{array}{l}27^{\circ} \mathrm{C} \text { luz } \\
24-25^{\circ} \mathrm{C} \text { escuro }\end{array}$ & $16 \mathrm{~h}$ & 3.000 lux & $\begin{array}{l}\text { Goussard (1981); } \\
\text { Goussard (1982) }\end{array}$ \\
\hline $25 \pm 1^{\circ} \mathrm{C}$ & $16 \mathrm{~h}$ & 3.000 lux & Troncoso et al. (1988) \\
\hline $25^{\circ} \mathrm{C}$ & $16 \mathrm{~h}$ & $3.0001 u x$ & Fanizza et al. (1988) \\
\hline $23^{\circ} \mathrm{C}$ & $16 \mathrm{~h}$ & - & Fanizza et al. (1984) \\
\hline $25 \pm 1^{\circ} \mathrm{C}$ & $15 \mathrm{~h}$ & $50 \mu \mathrm{mol} / \mathrm{m}^{2} \mathrm{~s}$ & Barlass (1987) \\
\hline $\begin{array}{l}27^{\circ} \mathrm{C} \text { luz } \\
20^{\circ} \mathrm{C} \text { escuro }\end{array}$ & $15 \mathrm{~h}$ & $50 \mu \mathrm{E} / \mathrm{m}^{2} \mathrm{~s}$ & $\begin{array}{l}\text { Barlass \& Skene (1978); } \\
\text { Barlass \& Skene (1980a); } \\
\text { Barlass \& Skene (1980b) }\end{array}$ \\
\hline $21^{\circ} \mathrm{C}$ & $14 \mathrm{~h}$ & $40 \mu \mathrm{mol} / \mathrm{m}^{2} \mathrm{~s}$ & Galzy \& Compan (1992) \\
\hline $\begin{array}{l}30^{\circ} \mathrm{C} \text { luz } \\
26^{\circ} \mathrm{C} \text { escuro }\end{array}$ & $12 \mathrm{~h}$ & $98 \mu \mathrm{mol} / \mathrm{m}^{2} \mathrm{~s}$ & Li \& Eaton (1984) \\
\hline $\begin{array}{l}25^{\circ} \mathrm{C} \text { luz } \\
20 \pm 1^{\circ} \mathrm{C} \text { escuro }\end{array}$ & $10 \mathrm{~h}$ & $48,8 \mu \mathrm{mol} / \mathrm{m}^{2} \mathrm{~s}$ & Martinez \& Tizio (1989) \\
\hline $\begin{array}{l}27^{\circ} \mathrm{C} \text { luz } \\
18^{\circ} \mathrm{C} \text { escuro }\end{array}$ & $10 \mathrm{~h}$ & $1.900-2.200 \mu \mathrm{W} / \mathrm{cm}^{2}$ & Chée \& Poll (1983) \\
\hline $\begin{array}{l}27^{\circ} \mathrm{C} \text { luz } \\
21^{\circ} \mathrm{C} \text { escuro }\end{array}$ & $10 \mathrm{~h}$ & $1.900 \mu \mathrm{W} / \mathrm{cm}^{2}$ & $\begin{array}{l}\text { Chée \& Pool (1985); } \\
\text { Chée \& Pool (1987) }\end{array}$ \\
\hline $\begin{array}{l}27^{\circ} \mathrm{C} \text { luz } \\
21^{\circ} \mathrm{C} \text { escuro }\end{array}$ & $10 \mathrm{~h}$ & $22 \mathrm{~W} / \mathrm{m}^{2}$ & Chée \& Poll (1988) \\
\hline
\end{tabular}


A temperatura não deve atingir $38^{\circ} \mathrm{C}$, pois esta foi letal para os explantes de diversos cultivares de videira (Barlass et al., 1981; Fanizza et al., 1988).

$\mathrm{O}$ fotoperíodo pode alterar o crescimento das plantas in vitro, já que controla as mudanças no conteúdo endógeno de hormônios (Alleweldt \& Radler, 1962). Mas o comportamento varietal é bem diferenciado. Chée \& Pool (1982) verificaram que o desenvolvimento de brotações e enraizamento do cultivar Rougeon foi melhor em dias curtos (10h). Este resultado foi confirmado por Chée \& Pool (1983), que também observaram em efeito benéfico de dias curtos (10h) na produção de brotações de 'Concord' e 'Cabernet Sauvignon', enquanto Vitis argentifolia comportou-se melhor em dias longos (16h). Já outros 14 cultivares apresentaram comportamento semelhante em dias curtos e longos. 


\section{MATERIAL E MÉTODOS}

\subsection{Descrição dos cultivares utilizados}

De acordo com as descrições de Barros (1995), Pereira \& Leitão Filho (1973), Pommer (1993) e Terra et al. (1993), as principais características dos cultivares utilizados neste trabalho são as seguintes:

\section{'Kober 5BB'}

Obtido pelo cruzamento entre as espécies $V$. berlandieri e $V$. riparia, realizado por Teleki e selecionado por Kober, na Áustria, no início deste século.

Seus ramos lignificam tardiamente e o mesmo acontece em relação à brotação de suas estacas, porém o índice de pegamento é bom. Apresenta vigor médio e boa resistência a seca. Adapta-se a diferentes tipos de solos, desde que não sejam excessivamente ácidos. Suas folhas possuem boa resistência às doenças fúngicas. Produz flores femininas, podendo ocorrer frutificação.

Recomendado para os cultivares Itália e Rubi, embora as plantas revelem, quase sempre, um engrossamento do tronco acima do ponto de enxertia, indicando a falta de vigor do porta-enxerto em relação à copa.

\section{'Ripária do Traviú'}

Obtido por Millardet e de Grasset, na França em 1882, através do cruzamento entre $V$. riparia $\times$ ( $V$. rupestris $\times V$. cordifolia). Foi introduzido em 
Jundiaí como $V$. riparia, sendo mais conhecido pelo nome de 'Ripária do Traviú' ou simplesmente 'Traviú'.

Tornou-se o porta-enxerto mais difundido no Estado de São Paulo por ter sido o mais recomendado para 'Niagara'. Suas estacas mostram ótimo pegamento e a planta apresenta bom desenvolvimento, porém sem muito vigor. Adapta-se bem a muitos tipos de solos, inclusive os ácidos, mas é suscetível à antracnose, necessitando de tratamentos fitossanitários durante o desenvolvimento vegetativo.

Embora muito utilizado para 'Niagara', possui afinidade com outros cultivares, inclusive Itália, Rubi, Patrícia, Paulistinha e Máximo (IAC 138-22).

\section{'Campinas' (IAC 766)}

Obtido pelo cruzamento entre o porta-enxerto 'Ripária do Traviú' com a espécie $V$. caribaea, realizado por Santos Neto em 1958.

A planta é vigorosa e bem adaptada às condições ambientais paulistas. Suas folhas são bastante resistentes às doenças. Seus ramos hibernam melhor que os do 'Tropical' e suas estacas apresentam bom índice de pegamento.

Foi entregue ao cultivo em 1970. Apresenta boa afinidade com a maioria dos cultivares copa testados. Vem sendo amplamente utilizado no Estado de São Paulo, sendo recomendado para os cultivares Itália, Rubi, Benitaka, Niagara, Red Globe, Centennial Seedless, Patrícia, Maria, Paulistinha e Máximo.

\section{'Jales' (IAC 572)}

Obtido pelo cruzamento entre $V$. caribaea e $V$. riparia $\mathrm{x} V$. rupestris 10114, realizado por Santos Neto em 1955.

A planta é vigorosa, adaptando-se bem em solos argilosos e arenosos. Suas estacas apresentam ótimo pegamento e suas folhas são resistentes às principais doenças. 
Foi lançado para o cultivo em 1970. Apresenta bom resultados como portaenxerto para os cultivares Niagara, Máximo, Itália, Rubi e Benitaka.

\section{'Tropical' (IAC 313)}

Obtido pelo cruzamento entre 'Golia' com a espécie $V$. cinerea, realizado por Santos Neto em 1950.

Suas estacas apresentam bom índice de pegamento. Seus ramos lignificam tardiamente, acontecendo o mesmo em relação à brotação das estacas. Suas folhas apresentam boa resistência às doenças. As plantas são muito vigorosas e adaptamse bem às condições climáticas paulistas, também tolerando diferentes tipos de solos, inclusive aqueles com elevada acidez.

Foi entregue ao cultivo em 1955 e desde então vem sendo usando no Estado de São Paulo e no Vale do Rio São Francisco, onde, através da irigação, controla-se melhor sua vegetação, já que seus ramos não hibernam adequadamente. Bom porta-enxerto para os cultivares Itália, Rubi, Benitaka, Patrícia, Red Globe, Paulistinha e Máximo.

\section{'Itália'}

É o cultivar mais importante de uvas finas no Brasil, tendo sua produção concentrada nos Estados de São Paulo, Paraná, Minas Gerais e na região do Vale do Rio São Francisco.

A planta é muito vigorosa, de ciclo longo e com produtividade média de $30 t / h a$. Apresenta pequena resistência às doenças e pragas. Necessita de poda longa (8 a 12 gemas).

Os cachos possuem forma cilíndrico-cônica, são grandes (400 a 800g), alongados e naturalmente compactos, necessitando de intenso desbaste. Também apresentam boa resistência ao transporte e ao armazenamento. 
As bagas são grandes (8 a 12g), de cor esverdeada a levemente amarelada quando maduras, forma ovalada, com textura trincante e sabor neutro levemente moscatel.

\subsection{Experimento de estaquia lenhosa}

3.2.1. Efeito do diâmetro da estaca lenhosa no desenvolvimento dos porta-enxertos 'Jales' e 'Campinas'

Este experimento foi instalado em sacos plásticos preenchidos apenas com terra de subsolo e mantidos ao ar livre em Campinas (SP).

$\mathrm{O}$ delineamento experimental foi inteiramente casualizado em esquema fatorial ( $3 \times 2$ ), onde foram combinados 3 diâmetros de estaca e 2 porta-enxertos, resultando nos seguintes tratamentos com suas respectivas repetições:

1)Finas (5 a 7mm) / 'Campinas' - 12 repetições

2)Médias (7 a 9mm) / 'Campinas' - 14 repetições

3)Grossas (9 a 12mm) / 'Campinas' - 9 repetições

4)Finas (5 a 7mm) / 'Jales' - 9 repetições

5)Médias (7 a 9mm) / 'Jales' - 11 repetições

6)Grossas (9 a 12mm) / 'Jales' - 11 repetições

Foram utilizadas 8 estacas por parcela sendo plantadas individualmente nos sacos plásticos.

As estacas foram coletadas no dia 22 de julho de 1994 das plantas matrizes livres de vírus do Instituto Agronômico (IAC) em Campinas (SP). As estacas foram preparadas com o comprimento médio de $55 \mathrm{~cm}$, contendo 5 gemas. O corte na parte basal foi realizado perpendicularmente e logo abaixo de uma gema, e na parte superior inclinado e cerca de $3 \mathrm{~cm}$ acima de uma gema. 
Após o preparo, foram formados feixes de 100 estacas e tratados por imersão em solução de captan $(2 \mathrm{~g} / \mathrm{L})$ durante 30 segundos. Depois de secas a sombra, as estacas foram enroladas em jornal úmido, colocadas dentro de sacos plásticos e armazenadas em câmara fria por 3 dias.

Após o armazenamento, as estacas foram colocadas em pé dentro de caixas plásticas, onde permaneceram por 48 horas, com a base imersa em água.

No plantio, as estacas foram enterradas no substrato, deixando-se 2 gemas fora do solo, e logo em seguida foi realizada uma irrigação.

A avaliação do experimento foi realizada 4 meses após sua instalação através da porcentagem de pegamento, número de gemas brotadas por estaca, comprimento médio das brotações por estaca, número médio de folhas por brotação e comprimento médio dos entrenós.

\subsection{Experimentos de estaquia semilenhosa}

Os experimentos foram instalados dentro de uma câmara de nebulização intermitente, com controle automático de rega, localizada na Seção de Viticultura do Instituto Agronômico (IAC) em Campinas (SP), durante o período de novembro de 1995 a março de 1996.

As estacas foram coletadas de plantas-matrizes livres de vírus presentes no mesmo local da estaquia, sendo utilizados ramos com 0,5 a $1 \mathrm{~m}$ de comprimento, que possuiam crescimento vertical.

Imediatamente após a coleta, os ramos foram colocados dentro de grandes bandejas com água e cobertos com jornal úmido para evitar sua desidratação.

As estacas foram preparadas a partir de regiões dos ramos com caule verde, porém lignificado, desprezando a porção mais tenra do ápice. As estacas 
possuiam apenas uma gema com uma folha completamente desenvolvida no ápice e comprimento de 5 a $10 \mathrm{~cm}$. Apenas no primeiro experimento foram testadas outras formas de preparo das estacas.

A estaquia foi realizada em bandejas de isopor com 72 células, sendo utilizadas apenas a metade das células para não sobrepor as folhas das estacas. $O$ substrato utilizado foi uma mistura comercial denominada "Multiplant".

Todos os experimentos foram avaliados 21 dias após a estaquia. Os parâmetros avaliados foram: enraizamento, expresso pela porcentagem de estacas que emitiram pelo menos uma raiz; retenção foliar, expressa pela porcentagem de estacas que não perderam a folha; brotação, expressa pela porcentagem de estacas cuja gema localizada junto a folha apresentou pelo menos uma folha verde visível; mortalidade, expressa pela porcentagem de estacas que morreram; número de raízes, sendo contadas apenas as principais que se originaram diretamente da estaca; peso de raízes, obtido pela pesagem em balança analítica de todas as raízes de uma estaca, após serem lavadas; volume de raízes, obtido pela diferença de volume ocasionado pela colocação das raízes dentro de uma proveta com água.

\subsubsection{Efeito de diferentes formas de preparo no enraizamento de estacas semilenhosas dos porta-enxertos 'Jales', 'Campinas' e 'Tropical'}

Foram instalados três experimentos, um com o porta-enxerto 'Jales' no dia 25 de janeiro de 1996, outro com o 'Campinas', no dia 30 de janeiro de 1996 e outro com o 'Tropical', no dia 4 de março de 1996.

Os tratamentos foram as seguintes formas de preparo das estacas: 
1)Estaca com ferimento: preparada através de 4 cortes, com $2 \mathrm{~cm}$ de comprimento, feitos com bisturi em lados opostos da base da estaca.

2)Estaca com nó na base: preparada através de um corte horizontal e logo abaixo de um nó localizado na base da estaca.

3)Estaca com entrenó na base: preparada apenas com uma gema no ápice e a base terminando no entrenó.

O delineamento experimental nos três experimentos foi inteiramente casualizado, com 4 repetições e 12 estacas por parcela.

\subsubsection{Efeito do AIB no enraizamento de estacas semilenhosas dos porta-enxertos 'Jales', 'Campinas', 'Ripária do Traviú' e 'Kober 5BB'}

Este experimento foi instalado no dia 30 de novembro de 1995. O delineamento experimental foi inteiramente casualizado, com 4 repetições e 12 estacas por parcela em esquema fatorial $(4 \times 4)$, onde foram combinadas 4 concentrações de AIB com 4 porta-enxertos, resultando nos seguintes tratamentos:

1)0ppm AIB / 'Jales'

2)0ppm AIB / 'Campinas'

3)0ppm AIB / 'Ripária do Traviư'

4)0ppm AIB / 'Kober 5BB'

5)500ppm AIB / 'Jales'

6)500ppm AIB / 'Campinas'

7)500ppm AIB / 'Ripária do Traviú'

8)500ppm AIB / 'Kober 5BB' 
9)1000ppm AIB / 'Jales'

10)1000ppm AIB / 'Campinas'

11)1000ppm AIB / 'Ripária do Traviú'

12)1000ppm AIB / 'Kober 5BB'

13)2000ppm AIB / 'Jales'

14)2000ppm AIB / 'Campinas'

15)2000ppm AIB / 'Ripária do Traviú'

16)2000ppm AIB / 'Kober 5BB'

As soluções de auxina foram preparadas utilizando AIB com procedência da Sigma, sendo diluídas em álcool 50\% e o tratamento das estaca foi através da imersão rápida (5 segundos) da base.

3.3.3. Efeito do AIB no enraizamento de estacas semilenhosas do porta-enxerto 'Tropical'

Este experimento foi instalado no dia 12 de janeiro de 1996. O delineamento experimental foi inteiramente casualizado com 4 repetições e 12 estacas por parcela. Os tratamentos foram os seguintes:

1)0ppm AIB

2)500ppm AIB

3)1000ppm AIB

4)2000ppm AIB

As soluções de auxina foram preparadas utilizando AIB com procedência da Sigma, sendo diluídas em álcool $50 \%$ e o tratamento das estaca foi através da imersão rápida (5 segundos) da base. 
3.3.4. Efeito da área foliar no enraizamento de estacas semilenhosas dos porta-enxertos 'Jales' e 'Campinas'

Foram instalados dois experimentos, um com o porta-enxerto 'Jales', no dia 12 de janeiro de 1996 e outro com o 'Campinas', no dia 6 de março de 1996.

O delineamento experimental nos dois experimentos foi em blocos ao acaso, com 4 repetições e 12 estacas por parcela.

Os tratamentos consistiram de estacas com folhas com as seguintes áreas foliares:
1) $0 \mathrm{~cm}^{2}$
2) $25 \mathrm{~cm}^{2}$
3) $50 \mathrm{~cm}^{2}$
4) $75 \mathrm{~cm}^{2}$
5) $100 \mathrm{~cm}^{2}$

Para obter a área foliar desejada, as folhas foram cortadas com tesoura de acordo com moldes plásticos de área conhecida e com formato quadrado.

Após o corte das folhas todas as estacas foram tratadas por imersão em solução de benomyl (1g/L).

3.3.5. Avaliação do crescimento de mudas dos porta-enxertos 'Tropical', 'Jales' e 'Campinas' obtidas por estaquia semilenhosa

Para avaliar o crescimento de mudas obtidas pela estaquia semilenhosa, foram plantadas em sacos plásticos estacas enraizadas dos porta-enxertos 'Tropical', 'Jales' e 'Campinas' no dia 19 de dezembro de 1995. 
Para a estaquia foram utilizadas estacas com apenas uma gema no ápice, uma folha inteira e a base terminando no entrenó. Após 21 dias, foram escolhidas as que possuiam melhor desenvolvimento radicular, sendo transferidas individualmente para sacos plásticos contendo um substrato preparado pela mistura de $4 \mathrm{~kg}$ de torta de mamona, $0,5 \mathrm{~kg}$ de calcário dolomítico e $0,5 \mathrm{~kg}$ de adubo 4-14-8 para cada $100 \mathrm{~kg}$ de terra de subsolo. O substrato foi preparado 7 meses antes do plantio.

O delineamento experimental foi inteiramente casualizado, com 3 repetições e 10 plantas por parcela. Os tratamentos foram os três porta-enxertos avaliados.

O experimento foi avaliado 140 dias após sua instalação, através da porcentagem de sobrevivência, comprimento médio da brotação, diâmetro médio da brotação medido $3 \mathrm{~cm}$ acima do local de inserção, peso da parte aérea, peso do sistema radicular e volume do sistema radicular.

\subsection{Experimentos de micropropagação}

Os experimentos foram realizados no Laboratório de Biotecnologia da Seção de Viticultura do Instituto Agronômico (IAC) localizado em Campinas (SP).

\subsubsection{Fonte de explantes}

Para o fornecimento contínuo e uniforme de explantes, foi utilizada a metodologia descrita por Goussard (1981). As estacas dos porta-enxertos foram coletadas das plantas matrizes livres de vírus do Instituto Agronômico (IAC) em Campinas (SP), durante o período de repouso vegetativo. Depois foram tratadas 
com captan $(2 \mathrm{~g} / \mathrm{L})$, enroladas em jornal úmido, acondicionadas dentro de sacos plásticos e armazenadas em câmara fria.

Quando houve necessidade de explantes, as estacas foram retiradas da câmara fria, cortadas em pedaços com 2 gemas e colocadas para brotar numa bancada com iluminação artificial, dentro de frascos com $100 \mathrm{~mL}$ de água. As brotações das estacas foram utilizadas em todos os experimentos como fonte para retirar os explantes, que consistiram em segmentos nodais ou ápices meristemáticos.

\subsubsection{Condições de crescimento}

Os frascos utilizados para a cultura in vitro foram tubetes com capacidade de $32 \mathrm{~mL}$, tampados com forminhas de alumínio usadas em confeitaria. Em cada frasco sempre foram adicionados $7 \mathrm{~mL}$ de meio de cultura.

Para a esterilização, os frascos com meio de cultura foram autoclavados a $120^{\circ} \mathrm{C}$ e $1 \mathrm{~atm}$, por 20 minutos.

Todos os experimentos foram mantidos dentro de uma sala climatizada, com fotoperíodo de 16 horas de luz, fornecida por lâmpadas fluorescentes do tipo luz do dia e gro-lux, e temperatura em torno de $25 \pm 3^{\circ} \mathrm{C}$.

\subsubsection{Efeito da BAP na indução do crescimento de ápices meristemáticos dos porta-enxertos 'Jales' e 'Campinas'}

Foram instalados dois experimentos, com delineamento experimental em blocos ao acaso, com 4 repetições e 10 frascos por parcela, sendo um para cada porta-enxerto. 
A assepsia das brotações das estacas foi realizada pela lavagem em água corrente durante 30 minutos, seguida pela imersão em solução de hipoclorito de sódio a $1 \%$ mais Tween 80 a $0,1 \%$ por 15 minutos e 4 lavagens em água esterilizada.

Os ápices meristemáticos foram retirados com estiletes e bisturis, dentro de uma câmara de fluxo laminar, com o auxílio de um microscópio estereoscópico, possuindo dois ou três primórdios foliares e com tamanho de aproximadamente $0,5 \mathrm{~mm}$. Após a extração, os ápices foram imediatamente transferidos para placas de petri contendo meio de cultura MS com a concentração de sais reduzida pela metade, $10 \mathrm{~g} / \mathrm{L}$ de sacarose, $4 \mathrm{~g} / \mathrm{L}$ de carvão ativado e $7 \mathrm{~g} / \mathrm{L}$ de ágar, sendo colocados 12 ápices por placa de petri.

Os ápices permaneceram durante 5 dias neste meio, quando então foram transferidos individualmente para tubetes, contendo meio de cultura MS com a concentração de sais reduzida pela metade, $30 \mathrm{~g} / \mathrm{L}$ de sacarose, $6,5 \mathrm{~g} / \mathrm{L}$ de ágar e as concentrações de BAP relativas a cada tratamento. Apenas foram transferidos os ápices que estavam verdes, enquanto os contaminados e oxidados foram eliminados.

Os tratamentos foram as seguintes concentrações de BAP:

1) $0 \mu \mathrm{M}$

2) $2,5 \mu \mathrm{M}$

3) $5 \mu \mathrm{M}$

4) $10 \mu \mathrm{M}$

Os experimentos foram avaliados após 30 e 60 dias da transferência dos ápices pelos seguintes parâmetros: porcentagem de explantes com crescimento, porcentagem de explantes oxidados, porcentagem de explantes contaminados e 
porcentagem de explantes com pelo menos uma folha expandida. Foram considerados explantes com crescimento aqueles que apresentaram pelo menos o triplo do tamanho do explante original.

3.4.4. Efeito do tempo de permanência no meio de indução sobre o crescimento de ápices meristemáticos do porta-enxerto 'Campinas'

O delineamento experimental foi inteiramente casualizado, com 3 repetições e 10 frascos por parcela. Os tratamentos foram cinco períodos de permanência no meio de cultura MS com a metade da concentração de sais, solidificado com $6,5 \mathrm{~g} / \mathrm{L}$ de ágar e acrescido de $10 \mu \mathrm{M}$ de BAP, a saber:

1)14 dias

2)21 dias

3)28 dias

4)35 dias

5)42 dias

Os isolamentos foram realizados semanalmente e avaliados todos no mesmo dia, duas semanas após a instalação do último tratamento.

A assepsia, o procedimento para retirada dos ápices e a avaliação foram os mesmos descritos no ítem 3.4.3. 


\subsubsection{Efeito da BAP na indução do crescimento de segmentos} nodais do porta-enxerto 'Jales'

O delineamento experimental foi inteiramente casualizado, com 4 repetições e 10 frascos por parcela. Em cada frasco foi colocado apenas um explante.

Os tratamentos foram as seguintes concentrações de BAP:

1) $0 \mu \mathrm{M}$

2) $2,5 \mu \mathrm{M}$

3) $5 \mu \mathrm{M}$

4) $10 \mu \mathrm{M}$

5) $20 \mu \mathrm{M}$

A assepsia das brotações das estacas, com cerca de 5 nós sem as folhas, que foram cortadas pelos pecíolos, foi realizada pela imersão em solução de oxitetraciclina $(15 \mathrm{mg} / \mathrm{L})+$ estreptomicina $(150 \mathrm{mg} / \mathrm{L})$ durante 30 minutos, seguida pela imersão em solução de hipoclorito de sódio a $1 \%$ mais Tween 80 a $0,1 \%$ por 15 minutos e 4 lavagens em água esterilizada.

O ápice das brotações foi desprezado e o restante foi dividido em segmentos nodais com cerca de $1 \mathrm{~cm}$ de comprimento, possuindo uma gema.

O meio de cultura utilizado foi o MS com a metade da concentração de sais e solidificado com $6,5 \mathrm{~g} / \mathrm{L}$ de ágar.

A avaliação do experimento foi realizada após 40 dias da sua instalação, através dos seguintes parâmetros: porcentagem de segmentos com brotação da gema axilar, comprimento da brotação, porcentagem de explantes com calo, porcentagem de explantes com raiz e porcentagem de explantes oxidados. 


\subsubsection{Efeito da posição do segmento nodal da brotação das estacas} sobre o crescimento dos explantes do porta-enxerto 'Jales'

O delineamento experimental foi inteiramente casualizado com 4 repetições e 10 frascos por parcela. Em cada frasco foi colocado apenas um explante.

Os tratamentos foram sete posições dos segmentos nodais, contadas a partir do primeiro nó abaixo do ápice da brotação das estacas.

A assepsia foi a mesma utilizada no ítem 3.4.5. O ápice das brotações foi eliminado e o restante foi dividido em segmentos nodais que diferiram em tamanho, aumentando do ápice para base, devido às diferentes posições.

O meio de cultura utilizado foi o MS com a metade da concentração de sais, solidificado com $6,5 \mathrm{~g} / \mathrm{L}$ de ágar e acrescido de $10 \mu \mathrm{M}$ de BAP.

A avaliação do experimento foi realizada após 40 dias da sua instalação pelos seguintes parâmetros: comprimento das brotações, porcentagem de explantes contaminados, porcentagem de explantes oxidados e porcentagem de explantes com calo.

\subsubsection{Efeito de diferentes meios de cultura no crescimento do porta-enxerto 'Jales'}

O delineamento foi em blocos ao acaso com 4 repetições e 10 frascos por parcela. Em cada frasco foi colocado um explante.

Os tratamentos foram os seguintes meios de cultura:

1)MS

2)MS/2 (MS com a metade da concentração de sais)

3)NN 
4)GZ (64)

5)GZ (90)

A composição dos meios de cultura pode ser observada na Tabela 3.

Os explantes consistiram em segmentos nodais com 1 folha, obtidos pelo segundo subcultivo de plantas do porta-enxerto 'Jales' que estavam crescendo em meio de cultura GZ (90) acrescido de $1 \mu \mathrm{M}$ de BAP.

A avaliação do experimento foi realizada após 33 dias da transferência pelos seguintes parâmetros: comprimento das brotações, número de folhas por brotação, comprimento médio dos entrenós, porcentagem de enraizamento, número de raízes por explante e porcentagem de explantes oxidados.

\subsubsection{Efeito do tamanho da folha do explante durante o subcultivo na multiplicação do porta-enxerto 'Jales'}

O delineamento foi inteiramente casualizado com 3 repetições e 10 frascos por parcela. Cada frasco recebeu um explante.

Os tratamentos foram explantes com os seguintes tamanhos de folha:

1)Sem folha

2)Pequena ( $\pm 0,5 \mathrm{~cm}$ de diâmetro)

3)Média ( $\pm 1 \mathrm{~cm}$ de diâmetro)

4)Grande ( $\pm 1,5 \mathrm{~cm}$ de diâmetro)

Os explantes foram retirados de plantas provenientes do segundo subcultivo em meio MS com a concentração de sais reduzida pela metade e isento de reguladores de crescimento.

O experimento foi avaliado após 30 dias pelos seguintes parâmetros: comprimento da brotação, porcentagem de enraizamento e de explantes com brotação, número de folhas por brotação e número de raízes por planta. 
TABELA 3. Composição química em $\mathrm{mg} / \mathrm{L}$ de alguns meios de cultura utilizados para a micropropagação de videiras.

\begin{tabular}{|c|c|c|c|c|}
\hline Macronutrientes & MS & NN & GZ (64) & GZ (90) \\
\hline $\mathrm{NH}_{4} \mathrm{NO}_{3}$ & 1650 & 720 & 320 & 160 \\
\hline $\mathrm{KNO}_{3}$ & 1900 & 950 & 125 & 1011 \\
\hline $\mathrm{KH}_{2} \mathrm{PO}_{4}$ & 170 & 68 & 122,5 & 122,5 \\
\hline $\mathrm{Ca}\left(\mathrm{NO}_{3}\right)_{2} \cdot 4 \mathrm{H}_{2} \mathrm{O}$ & - & - & 496 & 496 \\
\hline $\mathrm{CaCl}_{2} \cdot 2 \mathrm{H}_{2} \mathrm{O}$ & 440 & - & - & - \\
\hline $\mathrm{CaCl}_{2}$ & - & 166 & - & - \\
\hline $\mathrm{MgSO}_{4} \cdot 7 \mathrm{H}_{2} \mathrm{O}$ & 370 & 185 & 123,2 & 123,2 \\
\hline \multicolumn{5}{|l|}{ Micronutrientes } \\
\hline $\mathrm{Fe}_{2} \mathrm{SO}_{4} \cdot 7 \mathrm{H}_{2} \mathrm{O}$ & 27,8 & 27,8 & - & - \\
\hline $\mathrm{Fe}_{2}\left(\mathrm{SO}_{4}\right)_{3} \cdot 5 \mathrm{H}_{2} \mathrm{O}$ & - & - & 22,0 & 22,0 \\
\hline $\mathrm{Na}_{2}$ EDTA & 37,3 & 37,3 & - & - \\
\hline $\mathrm{H}_{3} \mathrm{BO}_{3}$ & 6,2 & 10,0 & 0,025 & 0,025 \\
\hline $\mathrm{MnSO}_{4} \cdot \mathrm{H}_{2} \mathrm{O}$ & 16,9 & 18,9 & 0,610 & 0,610 \\
\hline $\mathrm{ZnSO}_{4} \cdot 7 \mathrm{H}_{2} \mathrm{O}$ & 8,6 & 10,0 & 0,060 & 0,060 \\
\hline KI & 0,830 & - & 0,250 & 0,250 \\
\hline $\mathrm{Na}_{2} \mathrm{MoO}_{4} \cdot 2 \mathrm{H}_{2} \mathrm{O}$ & 0,250 & 0,25 & 0,024 & 0,024 \\
\hline $\mathrm{CoCl}_{2} \cdot 6 \mathrm{H}_{2} \mathrm{O}$ & 0,025 & - & 0,024 & 0,024 \\
\hline $\mathrm{BeSO}_{4} \cdot 4 \mathrm{H}_{2} \mathrm{O}$ & - & - & 0,050 & - \\
\hline $\mathrm{CuSO}_{4} .5 \mathrm{H}_{2} \mathrm{O}$ & 0,025 & 0,025 & 0,025 & 0,025 \\
\hline $\mathrm{NiCl}_{2} \cdot 6 \mathrm{H}_{2} \mathrm{O}$ & - & - & 0,024 & 0,024 \\
\hline \multicolumn{5}{|l|}{ Substâncias orgânicas } \\
\hline Tiamina. $\mathrm{HCl}$ & 0,1 & 0,5 & 1 & 1 \\
\hline Piridoxina.HCl & 0,5 & 5 & 1 & 1 \\
\hline Ácido nicotínico & 0,5 & 5 & 1 & 1 \\
\hline Glicina & 2 & 2 & - & - \\
\hline Biotina & - & 0,05 & 0,01 & 0,01 \\
\hline Ácido fólico & - & 0,5 & - & - \\
\hline Pantotenato de cálcio & - & - & 1 & 1 \\
\hline Mio-inositol & 100 & 100 & 10 & 10 \\
\hline Sacarose & 30.000 & 20.000 & 15.000 & 15.000 \\
\hline $\mathrm{pH}$ & 5,8 & 5,5 & 6,5 & 6,5 \\
\hline
\end{tabular}


3.4.9. Efeito da posição do explante durante o subcultivo na multiplicação do porta-enxerto 'Jales'

$\mathrm{O}$ delineamento foi inteiramente casualizado com 3 repetições e 10 frascos por parcela. Cada frasco recebeu um explante.

Os tratamentos foram as seguintes posições dos explantes a partir do ápice:

1)Ápice com uma folha em expansão

2)Primeiro segmento abaixo do ápice

3)Segundo segmento abaixo do ápice

4)Terceiro segmento abaixo do ápice

As plantas utilizadas foram provenientes do segundo subcultivo em meio MS com a concentração de sais reduzida pela metade e sem reguladores de crescimento.

O experimento foi avaliado após 30 dias pelos seguintes parâmetros: comprimento das brotações, número de folhas por brotação, porcentagem de brotação, porcentagem de enraizamento e número de raízes por explante.

3.4.10. Efeito de diferentes formas de aclimatização na sobrevivência das plantas do porta-enxerto 'Jales'

A aclimatização foi realizada dentro de uma câmara de nebulização em recipientes individuais preenchidos com o substrato comercial "Multiplant". Os recipientes consistiram de copos plásticos descartáveis de $200 \mathrm{~mL}$ com furos na parte basal.

As plantas utilizadas neste experimento foram provenientes do terceiro subcultivo, sendo escolhidas aquelas com tamanho semelhante, possuindo quatro folhas e bem enraizadas. 
Após a retirada dos frascos, as raízes foram lavadas em água corrente para retirar o meio de cultura e as plantas foram colocadas numa bandeja com água, onde permaneceram até o momento do transplante.

O delineamento experimental foi em blocos ao acaso com 4 repetições e 10 plantas por parcela.

Os tratamentos consistiram em duas formas de aclimatização:

1)Recipientes abertos

2)Recipientes fechados

No caso dos recipientes abertos, as plantas foram simplesmente colocadas nos copos plásticos e permeneceram sob nebulização.

Já no caso dos recipientes fechados, os copos plásticos com as plantas foram cobertos com outro copo plástico descartável e transparente de $300 \mathrm{~mL}$, que foi colocado invertido sobre o outro. Ainda neste caso, o copo com a planta foi colocado dentro de outro copo do mesmo tamanho contendo uma camada de $1 \mathrm{~cm}$ de vermiculita no fundo e não foi perfurado, para evitar que o substrato secasse, já que, estando coberto, não recebia a água da nebulização.

O experimento foi avaliado 21 dias após a sua instalação pela sobrevivência das plantas.

3.5. Comparação do desenvolvimento aéreo e radicular em recipientes de plantas obtidas por estaquia lenhosa e micropropagação dos porta-enxertos 'Jales' e 'Campinas'

O delineamento experimental foi em blocos ao acaso, com 4 repetições e 10 plantas por parcela.

Os tratamentos foram os seguintes tipos de muda: 
1)'Jales' / estaquia

2)'Jales' / micropropagação

3)'Campinas' / estaquia

4)'Campinas' / micropropagação

O plantio foi realizado em sacos plásticos com um substrato formado pela mistura de $4 \mathrm{~kg}$ de torta de mamona, $0,5 \mathrm{~kg}$ de calcário dolomítico e $0,5 \mathrm{~kg}$ de adubo 4-14-8 para cada $100 \mathrm{~kg}$ de solo.

As estacas possuiam cerca de $55 \mathrm{~cm}$ de comprimento com 5 gemas e permaneceram numa câmara fria por cerca de 2 meses até o plantio, que foi realizado no dia 27 de setembro de 1995.

As mudas micropropagadas foram obtidas a partir de segmentos nodais cultivados in vitro e aclimatizadas após o quarto subcultivo. O plantio foi realizado no dia 18 de outubro de 1995. Após o plantio, as mudas foram tutoradas com varas de bambu.

O experimento foi avaliado 7 meses após o plantio das mudas micropropagadas, através dos seguintes parâmetros: comprimento da maior brotação por planta, comprimento total das brotações por planta, comprimento médio dos entrenós, número médio de gemas por planta, peso da parte áerea, peso do sistema radicular e volume do sistema radicular.

3.6. Comparação do desenvolvimento aéreo e radicular em minirizotron de plantas obtidas por estaquia lenhosa e micropropagação dos porta-enxertos 'Jales' e 'Campinas'

O experimento foi instalado em quatro minirizotrons, construídos em madeira, com as seguintes dimensões: $1 \mathrm{~m}$ de largura, $1 \mathrm{~m}$ de altura e $0,07 \mathrm{~m}$ de 
espessura. A estrutura possuia uma inclinação de $60^{\circ}$ com o chão e na face interna foi colocada uma chapa de vidro com espessura de $6 \mathrm{~mm}$, para permititr a observação das raízes, recoberta com papelão para escurecer o substrato.

O espaço entre a chapa de vidro e a madeira foi preenchido com um substrato formado pela mistura de $0,5 \mathrm{~kg}$ de calcário dolomítico e $0,5 \mathrm{~kg}$ de adubo 4-14-8 para cada $100 \mathrm{~kg}$ de solo.

Em cada aparelho foram plantadas, no dia 31 de agosto de 1995, três estacas ou três mudas micropropagadas dos porta-enxertos 'Jales' e 'Campinas', distantes $30 \mathrm{~cm}$ entre si, resultando nos seguintes tratamentos:

1)'Jales' / estaquia

2)'Jales' / micropropagação

3)'Campinas' / estaquia

4)'Campinas' / micropropagação

Após o plantio, as mudas foram tutoradas em fios de arame com 1,5m de altura.

As avaliações iniciaram cerca de 90 dias após o plantio e foram realizadas em intervalos de 21 dias, até que as plantas entraram em repouso, totalizando 10 avaliações.

O desenvolvimento da parte aérea foi avaliado pelos seguintes parâmetros: comprimento total das brotações, número de brotações, número de folhas e área foliar.

A área foliar (AF) de cada planta foi determinada através da medida da largura (L) de todas as folhas de uma planta, que foram posteriormente convertidas em áreas pelas seguintes equações:

$$
\text { 'Jales': AF }=0,96 \text { ๆ }(\mathrm{L} / 2)^{2}
$$


'Campinas': $\mathrm{AF}=0,91$ ๆ $(\mathrm{L} / 2)^{2}$

Estas equações correspondem a área do círculo obtido utilizando-se a largura das folhas como diâmetro, encontradas em experimento anterior com alta confiabilidade para estimar a área foliar.

O desenvolvimento do sistema radicular foi avaliado colocando-se uma folha de celofane transparente sobre a chapa de vidro, onde foram desenhadas as raízes com caneta para retroprojetor. $\mathrm{O}$ celofane foi dividido em quadrículas de $20 \times 20 \mathrm{~cm}$, sendo utilizada a mesma folha em todas as avaliações para cada minirizotron. Assim, apenas o crescimento novo de raízes foi desenhado em cada avaliação, sendo utilizada para cada data uma caneta de cor diferente para diferenciá-las. Posteriormente a cada avaliação, foi contado o número de raízes e medido o comprimento das raízes em cada quadrícula.

Todos os dados obtidos resultaram da média das três plantas em cada aparelho.

3.7. Avaliação do desenvolvimento inicial a campo de mudas do cultivar Itália produzidas por diferentes métodos de enxertia sobre os porta-enxertos 'Jales' e 'Campinas'

O delineamento experimental foi inteiramente casualizado, com 5 repetições e 20 plantas por parcela, em esquema fatorial $(3 \times 2)$, onde foram combinados 3 tipos de enxertia com 2 porta-enxertos. Os tratamentos resultantes foram os seguintes:

1)Enxertia a campo na estaca / 'Jales'

2)Enxertia a campo na brotação / 'Jales'

3)Enxertia de mesa / 'Jales' 
4)Enxertia a campo na estaca / 'Campinas'

5)Enxertia a campo na brotação / 'Campinas'

6)Enxertia de mesa / 'Campinas'

O experimento foi instalado na Seção de Viticultura do Instituto Agronômico (IAC) em Campinas (SP).

O plantio foi realizado em linha, com espaçamento de $\mathrm{lm}$ entre plantas dentro da linha e $2 \mathrm{~m}$ entre linhas. Foram utilizadas 5 linhas de $120 \mathrm{~m}$, totalizando uma área experimental de $1200 \mathrm{~m}^{2}$, ficando cada parcela com $40 \mathrm{~m}^{2}$.

O sistema de condução já estava instalado antes da execução deste experimento, sendo uma espaldeira formada por 3 fios, distantes $40 \mathrm{~cm}$ entre si e $80 \mathrm{~cm}$ do solo.

\section{Preparo das estacas.}

As estacas dos porta-enxertos foram coletadas no dia 27 de julho de 1994, de plantas matrizes livres de vírus da Seção de Viticultura do Instituto Agronômico (IAC) em Campinas (SP).

As estacas foram preparadas com o comprimento médio de $55 \mathrm{~cm}$, contendo 5 gemas. $\mathrm{O}$ corte na parte basal foi realizado perpendicularmente e logo abaixo de uma gema, e na parte superior inclinado e cerca de $3 \mathrm{~cm}$ acima de uma gema. As estacas do 'Jales' apresentaram peso médio de 26,5g e as do 'Campinas', 21,5g.

Após o preparo, foram formados feixes de 100 estacas as quais foram tratadas por imersão em solução de captan $(2 \mathrm{~g} / \mathrm{L})$ durante 30 segundos. Após a secagem à sombra, as estacas foram colocadas em pé dentro de caixas plásticas, onde permaneceram por 48 horas, com a base imersa em água. 
Plantio e condução dos porta-enxertos no primeiro ano.

O plantio das estacas das parcelas com enxertia a campo foi realizado no dia 29 de julho de 1994, em covas previamente preparadas com as dimensões de $30 \times 30 \times 40 \mathrm{~cm}$, onde foram misturados ao solo $50 \mathrm{~g}$ de calcário dolomítico por cova. As estacas foram enterradas de forma a permanecer apenas 2 gemas para fora da terra.

$\mathrm{Na}$ mesma época do plantio a campo também foram plantadas aproximadamente 200 estacas de cada cultivar em sacos plásticos, para repor as eventuais falhas.

Após o plantio, todas as parcelas foram irrigadas, mantendo-se a irrigação duas vezes por semana até o início de novembro, quando começaram as chuvas regulares.

No dia 29 de novembro de 1994 foi realizado o replantio das falhas a campo e em seguida as brotações dos porta-enxertos foram tutoradas com varas de bambu até atingir o primeiro fio da espaldeira.

Os tratos culturais realizados durante o crescimento dos porta-enxertos, além da irrigação e tutoramento, já mencionados, foram capinas, controle de formigas através de iscas granuladas e uma adubação de cobertura realizada no dia 26 de janeiro de 1995, com 100g de adubo 4-14-8, distribuído ao redor das plantas e incorporado com enxada.

Enxertia de mesa.

No dia 15 de setembro de 1994 foi realizada a enxertia de mesa utilizando estacas dos porta-enxertos que foram coletadas na mesma época que as descritas anteriormente e preparadas de forma semelhante, sendo tratadas com captan 
$(2 \mathrm{~g} / \mathrm{L})$, enroladas em jornal úmido, colocadas em sacos plásticos e armazenadas em câmara fria até a sua utilização.

Os ramos do cultivar Itália foram coletados de um produtor em Jundiaí (SP) no dia 8 de agosto de 1994, também sendo tratados com captan (2g/L) e acondicionados da mesma forma em câmara fria até a data da enxertia.

A enxertia foi realizada com uma máquina manual com corte do tipo ômega. As estacas dos porta-enxertos foram preparadas com cerca de $45 \mathrm{~cm}$ de comprimento e três nós, sendo que as gemas dos nós superiores foram retiradas com tesoura de poda, deixando-se apenas a gema basal. Os garfos possuiam cerca de $10 \mathrm{~cm}$ de comprimento e apenas uma gema. Após a enxertia, o local enxertado foi amarrado com barbante.

As estacas enxertadas foram colocadas em pé dentro de grandes sacos plásticos perfurados, contendo cerca de $30 \mathrm{~L}$ de pó de xaxim úmido e levadas para dentro de uma casa de vegetação, onde permaneceram por 30 dias em estratificação.

Após este período, foram retiradas do pó de xaxim e imediatamente colocadas em pé dentro de uma caixa plástica com água, para evitar a desidratação das raízes já emitidas.

Em seguida, todos os enxertos, desde o local de enxertia até o ápice do garfo, foram revestidos com Parafilm M. Também foram retiradas as brotações dos porta-enxertos.

As estacas enxertadas foram então plantadas em sacos plásticos, contendo como substrato apenas terra de subsolo. Sobre cada enxerto foi colocado um saquinho feito com jornal para protegê-los da ação direta dos raios solares, que foram retirados 13 dias depois, quando ocorreu a brotação dos enxertos. 
Após 60 dias de crescimento nos sacos plásticos, as mudas enxertadas foram plantadas no campo, em covas previamente preparadas, sendo em seguida tutoradas com varas de bambu.

Durante o período do plantio até maio de 1995, as mudas foram pulverizadas com mancozeb $(2,8 \mathrm{~g} / \mathrm{L})$ em intervalos de 20 dias.

\section{Enxertia a campo.}

Para a enxertia a campo foram utilizados ramos do cultivar Itália coletados em Jales (SP), no dia 20 de junho de 1995 e armazenados em câmara fria devidamente acondicionados em sacos plásticos até a data da enxertia.

A enxertia foi realizada nos dias 22 e 23 de julho de 1995 por um enxertador com prática, sendo executada pelo método da garfagem de topo em fenda cheia, para ambos os tratamentos de enxertia na estaca e na brotação.

Para executar a enxertia na estaca, inicialmente foi cortada a copa do porta-enxerto cerca de 10 a $15 \mathrm{~cm}$ do solo e eliminadas todas as suas brotações. No centro do caule foi realizado um corte de forma a abrir uma fenda com aproximadamente $3 \mathrm{~cm}$. $\mathrm{O}$ garfo foi preparado com 2 gemas e na sua parte basal foram realizados 2 cortes inclinados formando uma cunha, a qual foi introduzida na fenda do porta-enxerto, fazendo coincidir a casca de ambos em pelo menos um dos lados. Depois, o enxerto foi amarrado com barbante e revestido totalmente com Parafilm M, recebendo também um saquinho de jornal para protegê-lo da ação dos raios solares, que foi retirado após 30 dias, quando ocorreu a brotação dos enxertos.

A enxertia na brotação foi realizada de forma semelhante, diferindo apenas por ser realizada numa brotação do porta-enxerto e não na estaca. Neste caso foi escolhida a brotação mais vigorosa para a enxertia e as outras foram eliminadas. 


\section{Condução do experimento no segundo ano.}

As mudas obtidas pela enxertia de mesa foram podadas em julho de 1995, reduzindo a brotação da copa para apenas duas gemas, devido ao pequeno crescimento dos ramos.

Quando a brotação dos enxertos realizados a campo atingiu cerca de 20 a $30 \mathrm{~cm}$ de comprimento, o barbante utilizado para amarrar o local de enxertia foi cortado para evitar o estrangulamento da muda. A partir desta ocasião, foram executados diversos tratos culturais que, dependendo da sua necessidade, foram repetidos até a avaliação final do experimento. Estes tratos foram o tutoramento da brotação do enxerto na vara de bambu e nos fios da espaldeira, esladroamento dos porta-enxertos, desnetamento da brotação do enxerto permitindo apenas o crescimento de um ramo por muda, capinas, irrigações, que foram realizadas três vezes em intervalos de 10 dias após a enxertia, e adubações que foram realizadas nos dias 15 de agosto de 1995 e 30 de janeiro de 1996 com 50g de adubo 4-14-8 por planta.

A partir do dia 27 de setembro de 1995 até 17 de abril de 1996 foram realizadas pulverizações semanais com mancozeb $(2,8 \mathrm{~g} / \mathrm{L})$ e nos meses de dezembro, janeiro e fevereiro, este produto foi alternado com três aplicações de metalaxyl $(24 \mathrm{mg} / \mathrm{L})+$ mancozeb $(1,92 \mathrm{~g} / \mathrm{L})$, aumentando o intervalo de aplicação para duas semanas. No mês de janeiro também foram efetuadas duas pulverizações com dimethoato $(0,8 \mathrm{~g} / \mathrm{L})$ para controlar o besouro Lagria villosa.

Avaliações.

Antes de realizar a enxertia das parcelas a campo, no dia 11 de julho de 1995, foi avaliado o desenvolvimento dos porta-enxertos e mudas de enxertia de 
mesa, através da medida dos diâmetros da estaca e das brotações dos portaenxertos ou do cultivar copa.

Nos porta-enxertos, o diâmetro da estaca foi medido $5 \mathrm{~cm}$ abaixo da brotação mais apical e nas brotações foi medido $5 \mathrm{~cm}$ após a sua inserção na estaca, medindo-se apenas a maior brotação por nó.

Nas mudas de enxertia de mesa o diâmetro da estaca foi medido $5 \mathrm{~cm}$ abaixo do local de enxertia e na brotação do garfo foi medido $5 \mathrm{~cm}$ após a sua inserção.

A partir do dia 8 de novembro de 1995 foram realizadas oito avaliações mensais do comprimento da brotação da copa do cultivar Itália, medindo-se desde a inserção da brotação no garfo até o ápice.

No dia 08 de junho de 1996 foi realizada a avaliação final do experimento através dos seguintes parâmetros: comprimento da brotação da copa, número de gemas por brotação, diâmetro da copa medido $5 \mathrm{~cm}$ acima do ponto de enxertia e peso da copa. 


\section{RESULTADOS E DISCUSSÃO}

\subsection{Experimento de estaquia lenhosa}

4.1.1. Efeito do diâmetro da estaca lenhosa no desenvolvimento dos porta-enxertos 'Jales' e 'Campinas'

O desenvolvimento das mudas foi influenciado pelo diâmetro das estacas e pelos cultivares. A análise de variância para o comprimento médio das brotações e comprimento médio dos entrenós revelou interação significativa entre os fatores estudados, mas não ocorreu para o pegamento, número médio de brotações por estaca e número de folhas por brotação (Apêndice 1).

Os porta-enxertos utilizados apresentaram elevado índice de pegamento, com uma média de $96,3 \%$ para o 'Jales' e $95,4 \%$ para o 'Campinas', não diferindo entre si (Tabela 4). Esses resultados já eram esperados devido à facilidade de enraizamento destes porta-enxertos, comprovada por Alvarenga \& Fortes (1976) e Terra et al. (1988b).

Também não houve diferença entre o diâmetro das estacas quanto ao pegamento e o número de brotações emitidas por estaca (Tabela 4). Pereira et al. (1978) trabalhando com os porta-enxertos 'Ripária do Traviú', 'Kober 5BB', 'RR 101-14', 'IAC 571-6' e 'Campinas', também não obtiveram diferença no pegamento de estacas com três diâmetros diferentes (finas, médias e grossas). 
Entretanto, o diâmetro das estacas afetou o desenvolvimento das plantas que, quanto mais grossas, apresentaram maior número de folhas (Tabela 4), maior comprimento das brotações e maior comprimento dos entrenós (Tabela 5). Este comportamento foi bastante semelhante para os dois porta-enxertos, mas mais acentuado para o 'Jales', onde todos os diâmetros diferiram significativamente entre si (Tabela 5).

Também observou-se que o 'Jales' apresentou maior vigor do que o 'Campinas', sendo significativamente superior quanto ao número de folhas emitidas por brotação (Tabela 4), comprimento das brotações e dos entrenós em todos os diâmetros de estaca (Tabela 5). Este maior desenvolvimento do 'Jales' também foi encontrado por Terra et al. (1988b), que obtiveram maior peso de matéria seca em brotações e raízes provenientes de estacas do porta-enxerto 'Jales' do que em estacas do 'Campinas'. O 'Jales' também se destacou como melhor porta-enxerto para o cultivar Máximo (Terra et al., 1990b) e apresentou maior produção média por planta do que o 'Campinas' para o cultivar Niagara Rosada (Terra et al., 1988a).

Apesar da inferioridade das estacas mais finas quanto ao desenvolvimento das plantas, o seu descarte não é necessário, como ressaltou Sousa (1996) recomendando a utilização de estacas com diâmetro próximo ao de um lápis, desde um pouco mais grossas até um pouco mais finas, semelhante ao utilizado neste experimento. 
TABELA 4. Efeito do diâmetro de estacas lenhosas dos porta-enxertos 'Jales' e 'Campinas' sobre o pegamento, número de brotações por estaca $\mathrm{e}$ número de folhas por brotação (Experimento 4.1.1; apêndice 1).

\begin{tabular}{lccc}
\hline Diâmetro & $\begin{array}{c}\text { Pegamento } \\
(\%)\end{array}$ & $\begin{array}{c}\text { Número de } \\
\text { brotações/estaca }\end{array}$ & $\begin{array}{c}\text { Número de } \\
\text { folhas/brotação }\end{array}$ \\
\hline Grossas & $96,2 \mathrm{a}^{1}$ & $1,73 \mathrm{a}$ & $14,1 \mathrm{a}$ \\
Médias & $96,0 \mathrm{a}$ & $1,69 \mathrm{a}$ & $12,6 \mathrm{~b}$ \\
Finas & $95,3 \mathrm{a}$ & $1,75 \mathrm{a}$ & $12,4 \mathrm{~b}$ \\
\hline Cultivar & & & \\
\hline Jales & $96,3 \mathrm{a}$ & $1,56 \mathrm{~b}$ & $15,4 \mathrm{a}$ \\
Campinas & $95,4 \mathrm{a}$ & $1,89 \mathrm{a}$ & $10,7 \mathrm{~b}$ \\
\hline C.V.(\%) & 7,0 & 12,4 & 8,7 \\
\hline
\end{tabular}

${ }^{1}$ Médias seguidas pela mesma letra não diferem significativamente pelo teste de Tukey a $5 \%$ de probabilidade.

TABELA 5. Efeito do diâmetro de estacas lenhosas dos porta-enxertos 'Jales' e 'Campinas' sobre o comprimento das brotações e dos entrenós (Experimento 4.1.1; apêndice 1).

\begin{tabular}{lcccc}
\hline \multirow{2}{*}{ iầmetro } & \multicolumn{2}{c}{$\begin{array}{c}\text { Comprimento das brotações } \\
(\mathrm{cm})\end{array}$} & $\begin{array}{c}\text { Comprimento dos entrenós } \\
(\mathrm{cm})\end{array}$ \\
\cline { 2 - 5 } & Jales & Campinas & Jales & Campinas \\
\hline Grossas & $74,0 \mathrm{Aa} 1$ & $32,4 \mathrm{Ba}$ & $4,5 \mathrm{Aa}$ & $2,7 \mathrm{Ba}$ \\
Médias & $61,2 \mathrm{Ab}$ & $22,7 \mathrm{Bb}$ & $3,9 \mathrm{Ab}$ & $2,2 \mathrm{Bb}$ \\
Finas & $51,8 \mathrm{Ac}$ & $20,4 \mathrm{Bb}$ & $3,5 \mathrm{Ac}$ & $2,0 \mathrm{Bb}$ \\
\hline C.V.(\%) & \multicolumn{3}{c}{7,6} \\
\hline 1Médias seguidas pela mesma letra maiúscula na linha e minúscula na coluna não \\
diferem significativamente pelo teste de Tukey a 5\% de probabilidade.
\end{tabular}




\subsection{Experimentos de estaquia semilenhosa}

4.2.1. Efeito de diferentes formas de preparo no enraizamento de estacas semilenhosas dos porta-enxertos 'Jales', 'Campinas' e 'Tropical'

A análise de variância para o efeito de diferentes formas de preparo das estacas nos três cultivares testados, apenas revelou diferenças significativas para 0 número de raízes emitidas por estaca para o 'Jales' e o 'Campinas' (Apêndices 2, 3 e 4).

A forma de preparo das estacas não afetou a porcentagem de enraizamento em nenhum dos três cultivares testados, permanecendo em todos acima de $80 \%$. O mesmo ocorreu com a retenção foliar, que não foi afetada pela forma de preparo e permaneceu em valores próximos ao enraizamento (Tabela 6).

A diferença entre os tratamentos foi verificada apenas quanto ao número de raízes por estaca, onde, para o 'Jales', houve um estímulo significativo para a maior emissão através do ferimento na base das estacas, tendência também observada para o 'Tropical', porém não significativa. $O$ ferimento na base das estacas é benéfico para o enraizamento de diversas espécies lenhosas por estimular a divisão celular e a formação de calos. A atividade celular na área lesionada é estimulada pelo aumento da taxa respiratória, elevação nos teores de auxinas, carboidratos e etileno, resultando na formação de raízes nas margens da lesão (Hartmann et al., 1990).

Já para o 'Campinas', o maior número de raízes foi observado nas estacas com nó na base, superior ao daquelas com ferimento e estas, por sua vez, mostraram número de raízes superior ao daquelas com entrenó na base (Tabela 6). 
TABELA 6. Efeito da forma de preparo ( $\mathrm{F}=$ ferimento; $\mathrm{N}=$ base com nó; $\mathrm{E}=$ base com entrenó) no enraizamento de estacas semilenhosas dos portaenxertos 'Jales', 'Campinas' e 'Tropical' (Experimento 4.2.1; apêndices $2,3$ e 4$)$.

\begin{tabular}{ccccccccccc}
\hline & \multicolumn{3}{c}{ Enraizamento (\%) } & \multicolumn{3}{c}{ Retenção foliar (\%) } & \multicolumn{3}{c}{ Número de raizes/estaca } \\
\cline { 2 - 11 } & \cline { 2 - 10 } & Tropical & Jales & Campinas & Tropical & Jales & Campinas & Tropical & Jales & Campinas \\
\hline F & $85,4 \mathrm{a}$ & $97,7 \mathrm{a}$ & $95,8 \mathrm{a}$ & $81,2 \mathrm{a}$ & $97,9 \mathrm{a}$ & $91,7 \mathrm{a}$ & $6,5 \mathrm{a}$ & $9,2 \mathrm{a}$ & $\mathbf{8 , 2 \mathrm { b }}$ \\
$\mathrm{N}$ & $83,3 \mathrm{a}$ & $83,3 \mathrm{a}$ & $93,8 \mathrm{a}$ & $79,2 \mathrm{a}$ & $91,7 \mathrm{a}$ & $91,7 \mathrm{a}$ & $5,5 \mathrm{a}$ & $6,8 \mathrm{~b}$ & $10,0 \mathrm{a}$ \\
$\mathrm{E}$ & $80,6 \mathrm{a}$ & $95,8 \mathrm{a}$ & $91,7 \mathrm{a}$ & $75,0 \mathrm{a}$ & $95,8 \mathrm{a}$ & $87,5 \mathrm{a}$ & $4,6 \mathrm{a}$ & $6,0 \mathrm{~b}$ & $6,8 \mathrm{c}$ \\
\hline C.V. (\%) & 16,8 & 9,4 & 5,7 & 21,2 & 9,1 & 10,2 & 19,4 & 15,8 & 6,8 \\
\hline
\end{tabular}

${ }^{\mathrm{T}}$ Médias seguidas pela mesma letra não diferem significativamente pelo teste de Tukey ao nível de $5 \%$ de probabilidade.

Apesar de apresentarem menor número de raízes, as estacas com entrenó na base foram mais práticas para a estaquia semilenhosa dos porta-enxertos, já que seu preparo é rápido, simples e de cada nó com folha pode-se obter uma estaca. A execução do ferimento é bastante trabalhosa e para o preparo de estacas com nó na base, perde-se muito material de propagação, praticamente obtendo-se metade do número de estacas preparadas com entrenó.

Estacas semilenhosas de diversos cultivares de videira com a base terminando no entrenó, já foram utilizadas com sucesso por Egger et al. (1985) e Moretti \& Borgo (1985). Esta forma de preparo das estacas também foi recomendada por Alley (1980) para a multiplicação rápida de videiras. O aspecto do enraizamento para os três cultivares pode ser observado na Figura 1. 


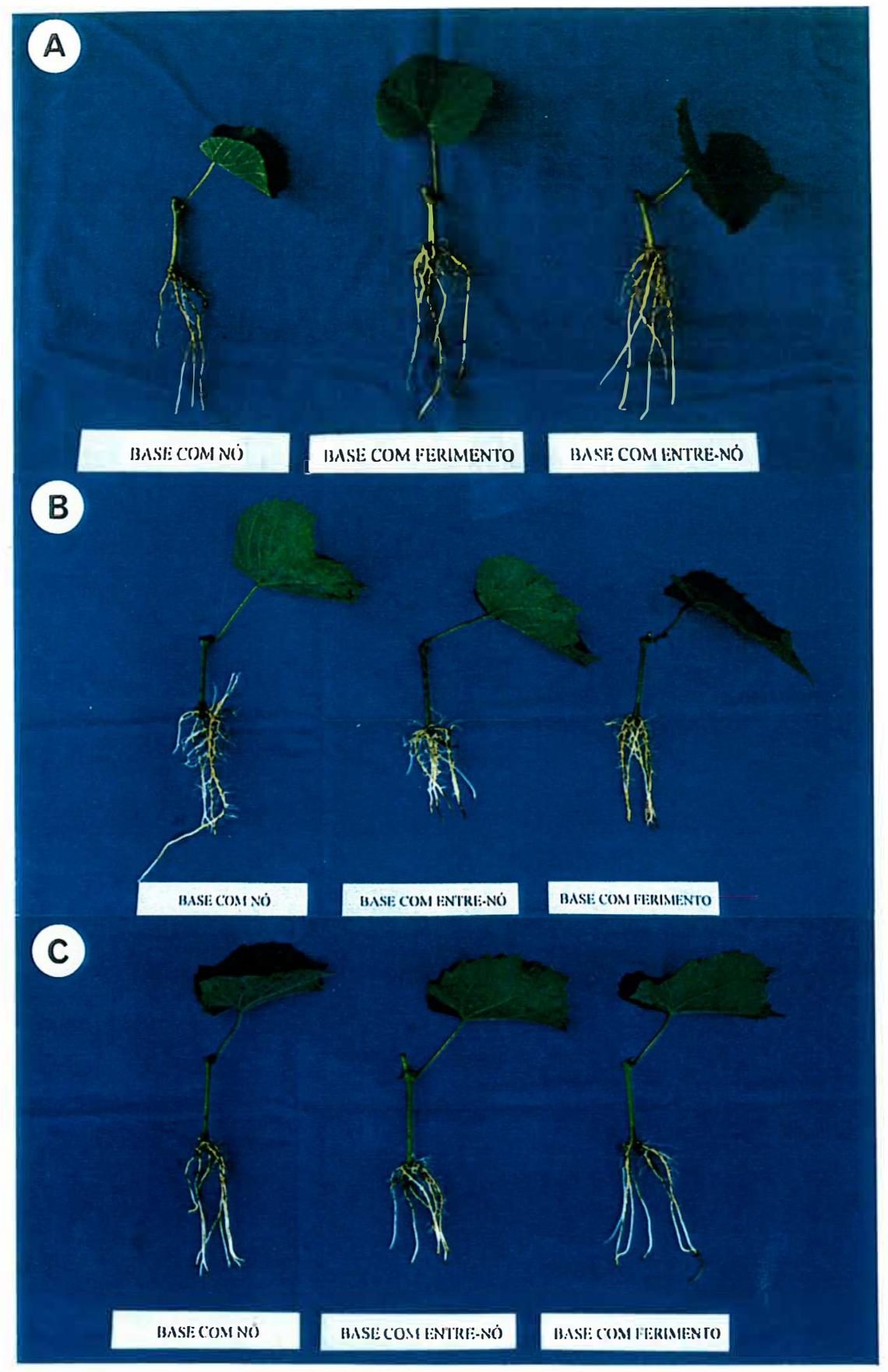

FIGURA 1. Efeito de diferentes formas de preparo no enraizamento de estacas semilenhosas dos porta-enxertos 'Tropical' (A), 'Jales' (B) e 'Campinas' (C) (Experimento 4.2.1). 


\subsubsection{Efeito do AIB no enraizamento de estacas semilenhosas dos porta-enxertos 'Jales', 'Campinas', 'Ripária do Traviú' e 'Kober 5BB'}

Não houve interação significativa entre porta-enxertos e concentrações de AIB em nenhuma variável estudada, permitindo a análise independente de cada fator (Apêndice 5).

O 'Jales' apresentou a maior porcentagem de estacas enraizadas $(89,6 \%)$, sendo significativamente superior ao 'Campinas' e ao 'Kober 5BB', mas não diferindo do 'Ripária do Traviú'. O 'Jales' também apresentou a maior retenção foliar, o que provavelmente permitiu o maior enraizamento e maior número de raízes emitidas por estaca (Tabela 7).

Estes resultados foram semelhantes aos encontrados por Alvarenga \& Fortes (1976) que trabalharam com os mesmos porta-enxertos, mas utilizaram estacas lenhosas. Nesse experimento os autores obtiveram a seguinte ordem decrescente de enraizamento: 'Jales' (97\%), 'Campinas' (92,5\%), 'Ripária do Traviú' (72,5\%) e 'Kober 5BB' (44,1\%). O 'Kober 5BB' também foi inferior ao 'Ripária do Traviú' no experimento realizado por Alvarenga (1976), mas neste caso o enraizamento foi bastante inferior, atingindo em média 29,6 e $20 \%$, respectivamente. Estes resultados são muito diferentes daqueles obtidos por Terra et al. (1981), que tratando estacas lenhosas destes porta-enxertos apenas por imersão da base em água durante 24 horas, obtiveram maior enraizamento com o 'Kober 5BB' (86,6\%), seguido pelo 'Campinas' (78,3\%), 'Jales' $(54,4 \%)$ e 'Ripária do Traviú' (53,3\%). Em outro experimento realizado por Terra et al. (1988b), o 'Kober 5BB' chegou a apresentar 98,7\% de estacas lenhosas enraizadas no mês de 
TABELA 7. Efeito de concentrações de AIB na propagação dos porta-enxertos 'Jales', 'Ripária do Traviú', 'Campinas' e 'Kober 5BB' através de estacas semilenhosas (Experimento 4.2.2; apêndice 5).

\begin{tabular}{|c|c|c|c|c|c|}
\hline Porta-enxertos & $\begin{array}{c}\text { Enraizamento } \\
(\%)\end{array}$ & $\begin{array}{l}\text { Retenção } \\
\text { foliar (\%) }\end{array}$ & $\begin{array}{c}\text { Brotação } \\
(\%)\end{array}$ & $\begin{array}{c}\text { Mortalidade } \\
(\%)\end{array}$ & $\begin{array}{l}\text { Número de } \\
\text { raizes/estaca }\end{array}$ \\
\hline Jales & $89,6 a^{2}$ & $89,1 a$ & $17,7 \mathrm{c}$ & $4,7 a$ & $8,3 a$ \\
\hline Ripária do Traviú & $77,1 \mathrm{ab}$ & $52,2 b$ & $69,3 a$ & $7,3 a$ & $5,3 c$ \\
\hline Campinas & $75,5 b$ & $44,8 b$ & $49,1 b$ & $3,6 a$ & $6,7 b$ \\
\hline Kober 5BB & $68,4 b$ & $54,2 \mathrm{~b}$ & $27,6 c$ & $10,4 a$ & $5,9 b c$ \\
\hline \multicolumn{6}{|l|}{ AIB (ppm) } \\
\hline 0 & $74,6 a$ & $60,1 a$ & $45,8 a$ & & \\
\hline 500 & $81,2 a$ & $65,3 a$ & $44,3 a$ & vide & vide \\
\hline 1000 & $80,0 a$ & $53,8 a$ & $39,1 \mathrm{a}$ & Figura 2 & Figura 3 \\
\hline 2000 & $74,6 a$ & $61,1 a$ & $34,5 a$ & & \\
\hline C.V.(\%) & 18,3 & 32,1 & 35,9 & 63,1 & 21,1 \\
\hline
\end{tabular}

${ }^{1}$ Dados transformados em $(x+1)^{1 / 2}$

${ }^{2}$ Médias seguidas pela mesma letra não diferem significativamente pelo teste de Tukey ao nível de $5 \%$ de probabilidade.

agosto, sendo superior ao 'Campinas' (90\%), 'Ripária do Traviú' (90\%) e 'Jales' $(88,7 \%)$.

Observa-se que há grandes diferenças entre os resultados de enraizamento obtidos por diversos autores, mas também pode-se constatar que o potencial de enraizamento de todos os porta-enxertos é alto e possivelmente estas diferenças ocorrem devido à condição fisiológica da planta-matriz no momento da coleta das estacas (Moe \& Andersen, 1988) e as condições do ambiente proporcionadas ao enraizamento (Loach, 1988) também serem diferentes em cada trabalho. Terra et al. (1988b) encontraram grandes variações no enraizamento de estacas quando coletadas em diferentes épocas do ano, o mesmo acontecendo no trabalho de Goode Junior \& Lane (1983). 
Nos diversos experimentos realizados neste trabalho também se observam pequenas diferenças de enraizamento para um mesmo cultivar, que possivelmente devem estar associadas às diferentes épocas de instalação de cada experimento. Mas, de forma geral, o enraizamento foi alto, sendo encontrados resultados de até 100\% para o 'Tropical' (Tabela 8), 'Jales' e 'Campinas' (Tabela 9).

O 'Ripária do Traviú' apresentou a maior porcentagem de estacas brotadas $(69,3 \%)$ superior aos demais porta-enxertos. Quanto à mortalidade das estacas não houve diferença entre os porta-enxertos (Tabela 7).

O tratamento das estacas com AIB não afetou a porcentagem de enraizamento, retenção foliar e brotação das estacas para os porta-enxertos 'Jales', 'Campinas', 'Ripária do Traviú' e 'Kober 5BB' (Tabela 7). Estes resultados concordam com os obtidos por Harmon (1943), que trabalhando com 31 portaenxertos concluiu que o AIB não foi suficientemente vantajoso para ser utilizado na propagação comercial de porta-enxertos de videira. Terra et al. (1981) testando o AIB para os mesmos porta-enxertos utilizados neste experimento, comprovaram que a simples imersão da base das estacas em água por 24 horas, proporcionou igual enraizamento ao obtido com esta auxina. Leonel \& Rodrigues (1993) também não observaram aumento significativo no enraizamento de estacas do porta-enxerto 'Ripária do Traviú' com a aplicação de soluções de AIB.

O aumento da concentração de AIB causou maior mortalidade das estacas, sendo encontrada uma regressão linear significativa para esta variável (Apêndice 6). Isto evidencia um efeito tóxico das concentrações mais elevadas de AIB (Figura 2) também observado por Leonel \& Rodrigues (1993) com o portaenxerto 'Ripária do Traviú' e por Silva et al. (1986) com os porta-enxertos 'SO4' e 'Rupestris du Lot'. 


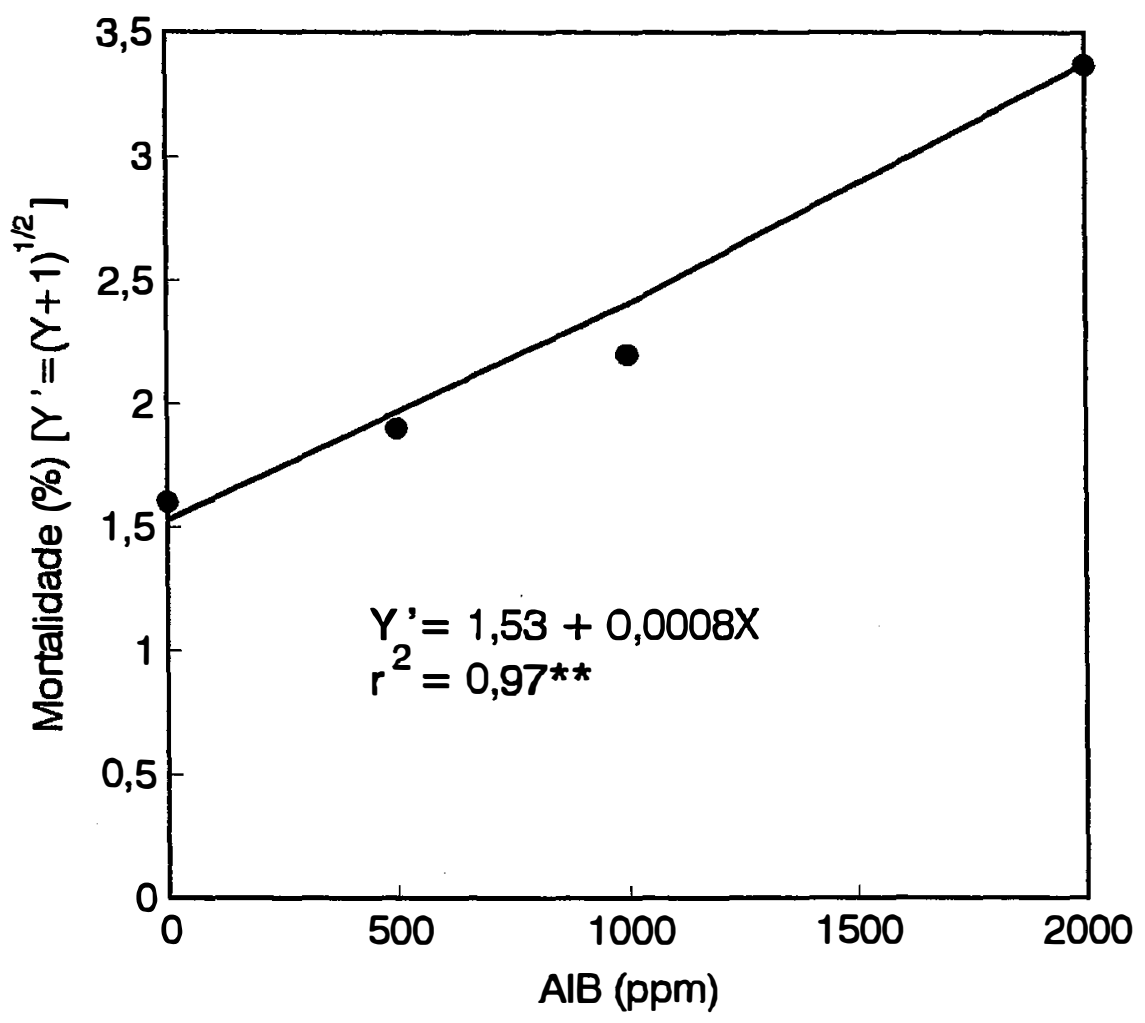

FIGURA 2. Efeito de concentrações de AIB na mortalidade de estacas semilenhosas de porta-enxertos de videira (Experimento 4.2.2; apêndice 6). 
Apesar do aumento da mortalidade, o uso do AIB também provocou maior emissão de raízes por estaca, sendo este comportamento melhor representado pela equação linear de regressão (Apêndice 6). $O$ número médio de raízes principais atingiu o valor máximo de 7,7 com o uso de 2000ppm de AIB, valor estimado pela equação de regressão, enquanto sem a utilização deste regulador, a média foi 5,6 raízes por estaca (Figura 3), uma diferença que apesar de significativa foi muito pequena. $\mathrm{O}$ efeito positivo do $\mathrm{AIB}$, no aumento do número de raízes formadas por estaca, já foi observado por Harmon (1943), Silva et al. (1986) e Tirio et al. (1961) em estacas lenhosas.

No trabalho de Silva et al. (1986) com os porta-enxertos 'SO4', 'RR 101-14' e 'Rupestris du Lot', apenas ocorreu redução na emissão de raízes com concentrações de AIB superiores a 2000ppm, o que está de acordo com os resultados deste experimento, dentro do mesmo intervalo.

\subsubsection{Efeito do AIB no enraizamento de estacas semilenhosas do porta-enxerto 'Tropical'}

$O$ efeito das concentrações de AIB foi significativo apenas para a porcentagem de brotação das estacas (Apêndice 7).

Como no experimento anterior, o AIB não afetou a porcentagem de enraizamento e a retenção foliar, evidenciando novamente que a aplicação deste regulador não é necessária para estimular o enraizamento (Terra et al., 1981), que atingiu $100 \%$ na testemunha (Tabela 8 ). 


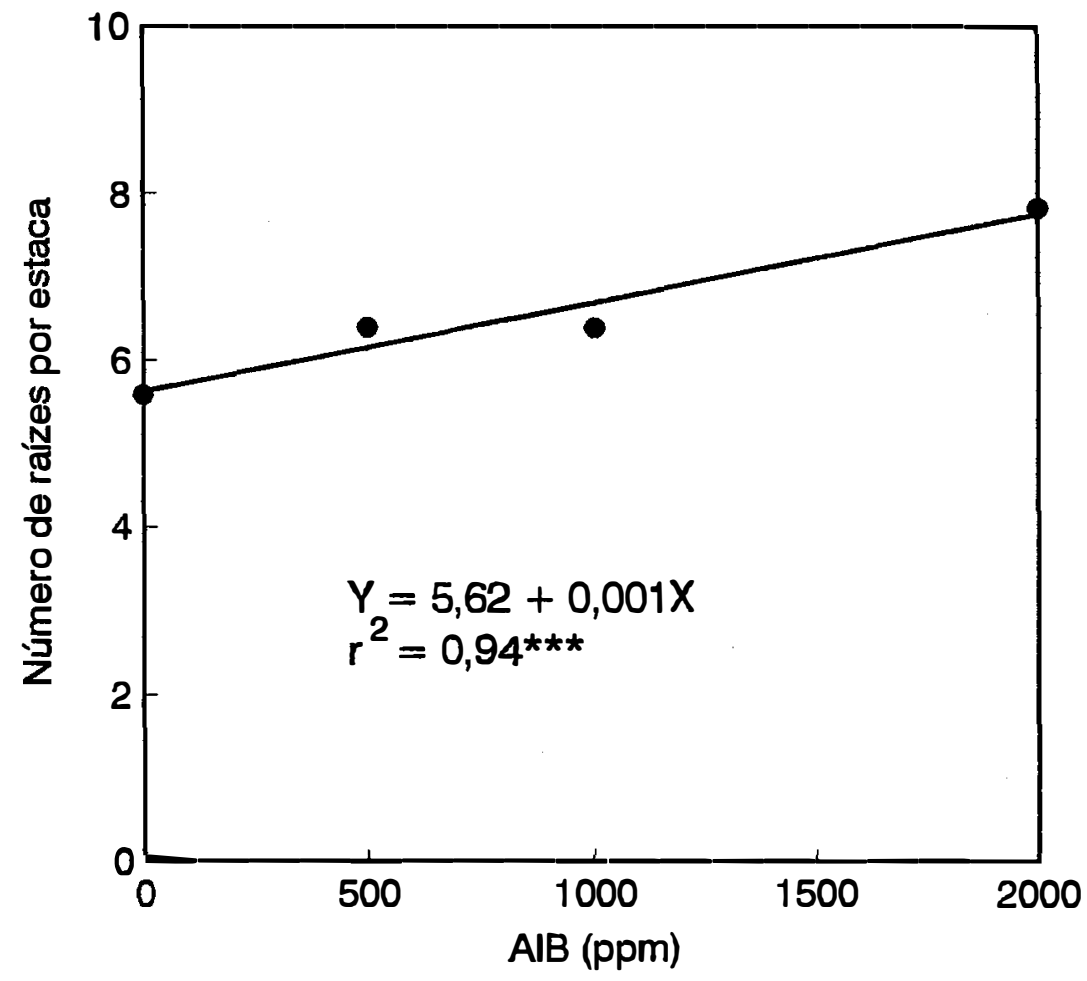

FIGURA 3. Efeito de concentrações de AIB no número de raízes emitidas por estaca semilenhosa de porta-enxertos de videira (Experimento 4.2.2; apêndice 6). 
TABELA 8. Efeito de concentrações de AIB no enraizamento de estacas semilenhosas do porta-enxerto 'Tropical' (Experimento 4.2.3; apêndice 7).

\begin{tabular}{cccccc}
\hline AIB (ppm) & $\begin{array}{c}\text { Enraizamento } \\
(\%)\end{array}$ & $\begin{array}{c}\text { Retenção } \\
\text { foliar (\%) }\end{array}$ & $\begin{array}{c}\text { Brotação } \\
(\%)\end{array}$ & $\begin{array}{c}\text { Mortalidade }^{1} \\
(\%)\end{array}$ & $\begin{array}{c}\text { Número de } \\
\text { raizes/estaca }\end{array}$ \\
\hline 0 & $100,0 \mathrm{a}^{2}$ & $89,6 \mathrm{a}$ & $16,7 \mathrm{a}$ & $0,0 \mathrm{a}$ & $8,7 \mathrm{a}$ \\
500 & $91,7 \mathrm{a}$ & $85,4 \mathrm{a}$ & $4,2 \mathrm{ab}$ & $8,3 \mathrm{a}$ & $8,2 \mathrm{a}$ \\
1000 & $97,9 \mathrm{a}$ & $97,9 \mathrm{a}$ & $2,1 \mathrm{~b}$ & $2,1 \mathrm{a}$ & $8,9 \mathrm{a}$ \\
2000 & $100,0 \mathrm{a}$ & $93,7 \mathrm{a}$ & $2,1 \mathrm{~b}$ & $0,0 \mathrm{a}$ & $9,9 \mathrm{a}$ \\
\hline C.V.(\%) & 5,7 & 8,6 & 43,3 & 74,6 & 15,4 \\
\hline
\end{tabular}

Tados transformados em $(x+1)^{1 / 2}$

${ }^{2}$ Médias seguidas pela mesma letra não diferem significativamente pelo teste de Tukey ao nível de $5 \%$ de probabilidade.

O 'Tropical' apresentou-se mais tolerante a doses altas de AIB do que os porta-enxertos 'Jales', 'Campinas', 'Ripária do Traviú' e 'Kober 5BB', pois mesmo com a maior concentração (2000ppm), a mortalidade foi nula e não diferiu significativamente dos demais tratamentos (Tabela 8).

Quanto ao número de raízes emitidas por estaca houve, como no experimento anterior, uma tendência de aumento com a maior concentração do regulador de crescimento, porém não significativa (Tabela 8).

\subsubsection{Efeito da área foliar no enraizamento de estacas semilenhosas dos porta-enxertos 'Jales' e 'Campinas'}

Todas as variáveis analisadas apresentaram significância estatística para os porta-enxertos 'Jales' (Apêndices 8 e 9) e 'Campinas' (Apêndices 10 e 11).

A presença da folha nas estacas foi indispensável para a formação de raízes, não ocorrendo enraizamento em estacas sem folha, para os cultivares Jales 
e Campinas (Figura 4). Entre os demais tratamentos, com diversas áreas foliares, não houve diferença significativa, sendo observados níveis elevados de enraizamento já com a menor área foliar de $25 \mathrm{~cm}^{2}$ (Tabela 9).

$\mathrm{O}$ efeito benéfico da presença das folhas em estacas semilenhosas para o enraizamento, já é bem conhecido, sendo atribuído à produção de auxinas e cofatores de enraizamento, que são transportados para a base das estacas (Altman \& Wareing, 1975; Breen \& Muraoka, 1974), e pela continuação do processo de fotossíntese, responsável pela síntese de carboidratos necessários como fonte de energia para formação e crescimento das raízes (Haissig, 1984; Davis, 1988).

A importância das folhas para o enraizamento já foi demonstrada na estaquia de abacateiro (Reuveni \& Raviv, 1981), araçazeiro (Nachtigal et al., 1994) e goiabeira (Pereira et al., 1983).

Nas estacas do porta-enxerto 'Jales', apenas ocorreu brotação quando elas possuiam folha, não ocorrendo diferença entre as área foliares testadas. Já para 0 'Campinas', mesmo as estacas sem folha brotaram em média 14,6\%, diferindo apenas da área de $25 \mathrm{~cm}^{2}$ que apresentou $66,7 \%$ de estacas brotadas (Tabela 9).

A falta da folha nas estacas provocou um alto índice de mortalidade, cerca de $50 \%$, para ambos os cultivares. Com a presença da folha, a mortalidade permaneceu abaixo de $2,1 \%$, não ocorrendo diferença entre as área foliares testadas (Tabela 9).

Apesar do tamanho da área foliar não afetar a porcentagem de enraizamento, houve um forte efeito sobre a emissão e crescimento das raízes, avaliado através do número, peso e volume de raízes por estaca. Entre estes parâmetros e as áreas foliares, em ambos os porta-enxertos, foram encontradas regressões quadráticas significativas (Apêndices 9 e 11). 


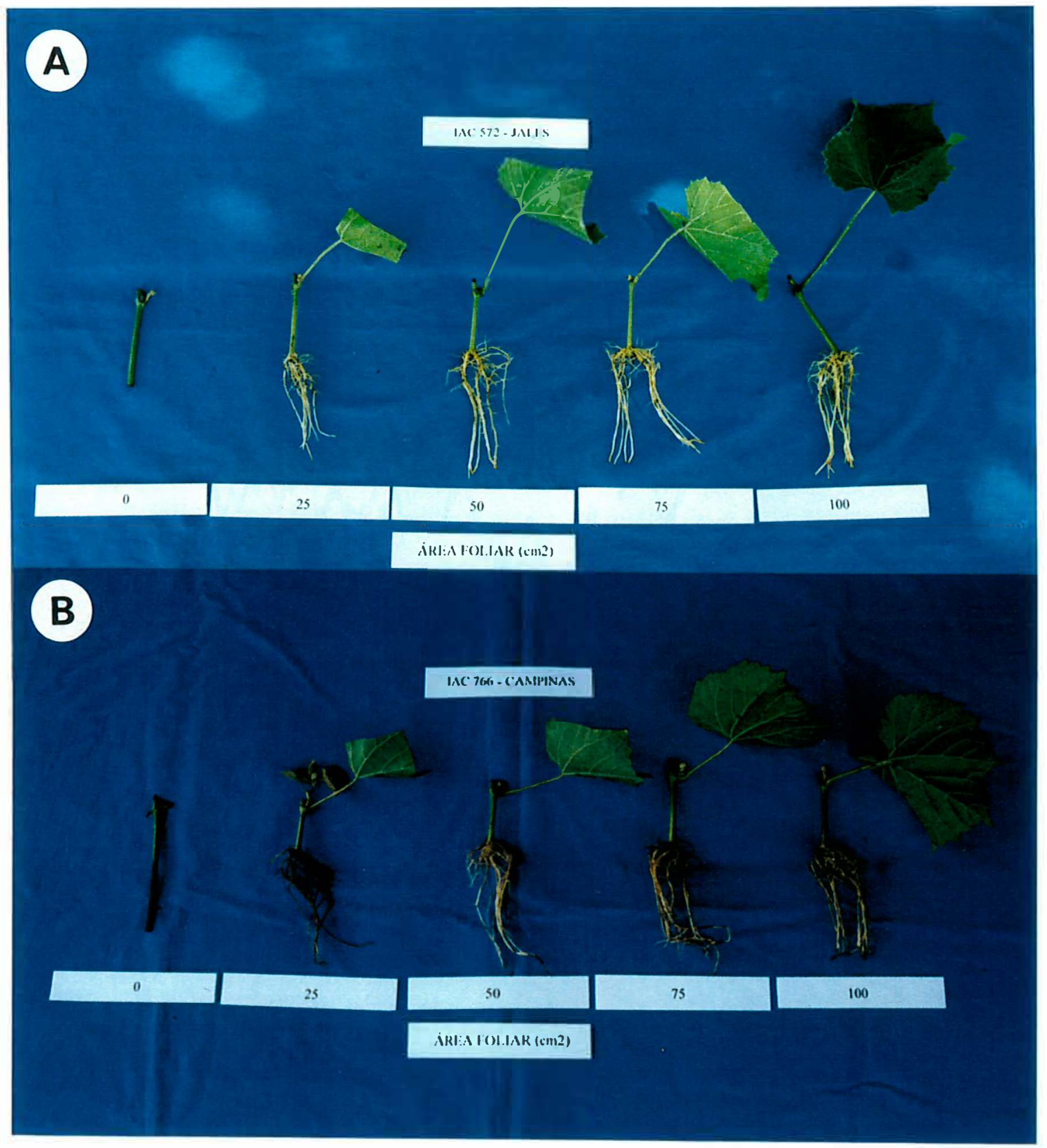

FIGURA 4. Efeito da área foliar sobre o enraizamento de estacas semilenhosas dos porta-enxertos 'Jales' (A) e 'Campinas' (B) (Experimento 4.2.4). 
TABELA 9. Efeito da área foliar no enraizamaento de estacas semilenhosas dos porta-enxertos 'Jales' e 'Campinas' (Experimento 4.2.4; apêndices $8 \mathrm{e}$ 10).

\begin{tabular}{ccccccc}
\hline Área foliar & \multicolumn{2}{c}{ Enraizamento (\%) } & \multicolumn{2}{c}{ Brotação $^{1}(\%)$} & \multicolumn{2}{c}{ Mortalidade ${ }^{1}(\%)$} \\
\cline { 2 - 7 }$\left(\mathrm{cm}^{2}\right)$ & Jales & Campinas & Jales & Campinas & Jales & Campinas \\
\hline 0 & $0,0 \mathrm{~b}^{2}$ & $0,0 \mathrm{~b}$ & $0,0 \mathrm{~b}$ & $14,6 \mathrm{~b}$ & $52,1 \mathrm{a}$ & $50,0 \mathrm{a}$ \\
25 & $92,9 \mathrm{a}$ & $100,0 \mathrm{a}$ & $14,6 \mathrm{a}$ & $66,7 \mathrm{a}$ & $2,1 \mathrm{~b}$ & $0,0 \mathrm{~b}$ \\
50 & $97,9 \mathrm{a}$ & $100,0 \mathrm{a}$ & $14,6 \mathrm{a}$ & $37,9 \mathrm{ab}$ & $2,1 \mathrm{~b}$ & $0,0 \mathrm{~b}$ \\
75 & $97,9 \mathrm{a}$ & $95,4 \mathrm{a}$ & $22,9 \mathrm{a}$ & $31,8 \mathrm{ab}$ & $0,0 \mathrm{~b}$ & $2,1 \mathrm{~b}$ \\
100 & $100,0 \mathrm{a}$ & $100,0 \mathrm{a}$ & $31,2 \mathrm{a}$ & $45,8 \mathrm{ab}$ & $0,0 \mathrm{~b}$ & $0,0 \mathrm{~b}$ \\
\hline C.V.(\%) & 5,1 & 2,9 & 38,7 & 32,8 & 76,2 & 83,9 \\
\hline
\end{tabular}

${ }^{1}$ Dados transformados em arc sen $(x / 100)^{1 / 2}$

${ }^{2}$ Médias seguidas pela mesma letra não diferem significativamente pelo teste de Tukey ao nível de $5 \%$ de probabilidade.

O aumento do tamanho da área foliar foi acompanhado pelo incremento do número de raízes emitidas por estaca até os valores de $91,4 \mathrm{~cm}^{2}$ para o 'Campinas' e $91,9 \mathrm{~cm}^{2}$ para o 'Jales', estimados pela equação de regressão, quando passou a sofrer uma redução (Figura 5).

Nestes valores de máximo, estimou-se uma emissão de 15,2 raízes por estaca para o 'Campinas' e 6,4 para o 'Jales'. Apesar da grande superioridade do 'Campinas' para este parâmetro, a diferença entre os porta-enxertos é bem menor quando observado o peso e o volume de raízes (Figuras 6 e 7), demonstrando uma compensação do 'Jales' pela maior emissão de raízes secundárias.

O aumento da área foliar também foi acompanhado pelo aumento do peso (Figura 6) e do volume (Figura 7) das raízes formadas, com tendências muito semelhantes já que estes parâmetros são estreitamente relacionados. Os valores máximos para ambos porta-enxertos extrapolaram a maior área foliar utilizada, sendo então apenas verificado o aumento de peso e volume dentro do intervalo de área foliar utilizado. 


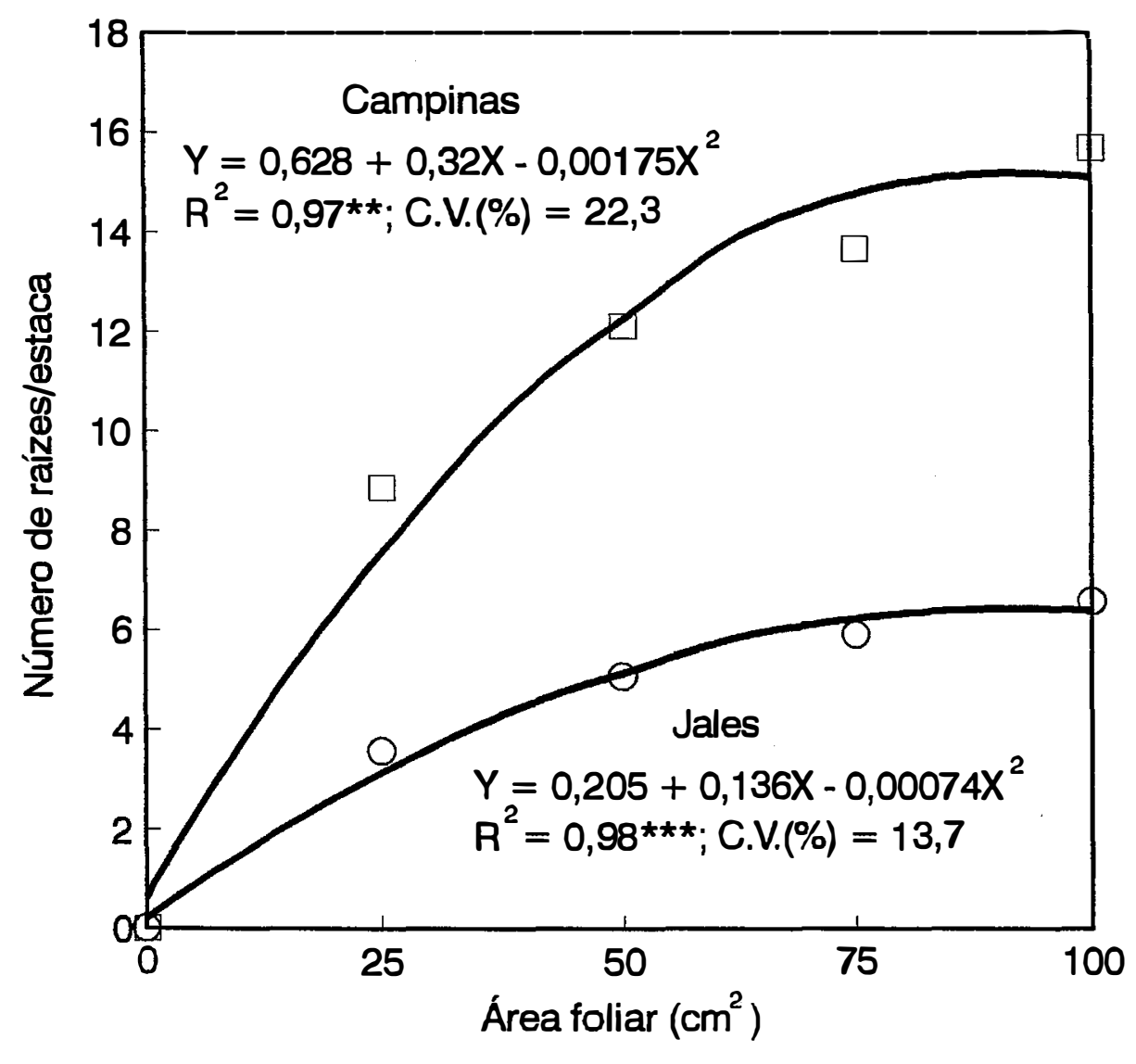

FIGURA 5. Efeito da área foliar sobre o número de raízes emitidas por estaca dos porta-enxertos 'Jales' e 'Campinas' (Experimento 4.2.4; apêndices $9 \mathrm{e}$ 11). 


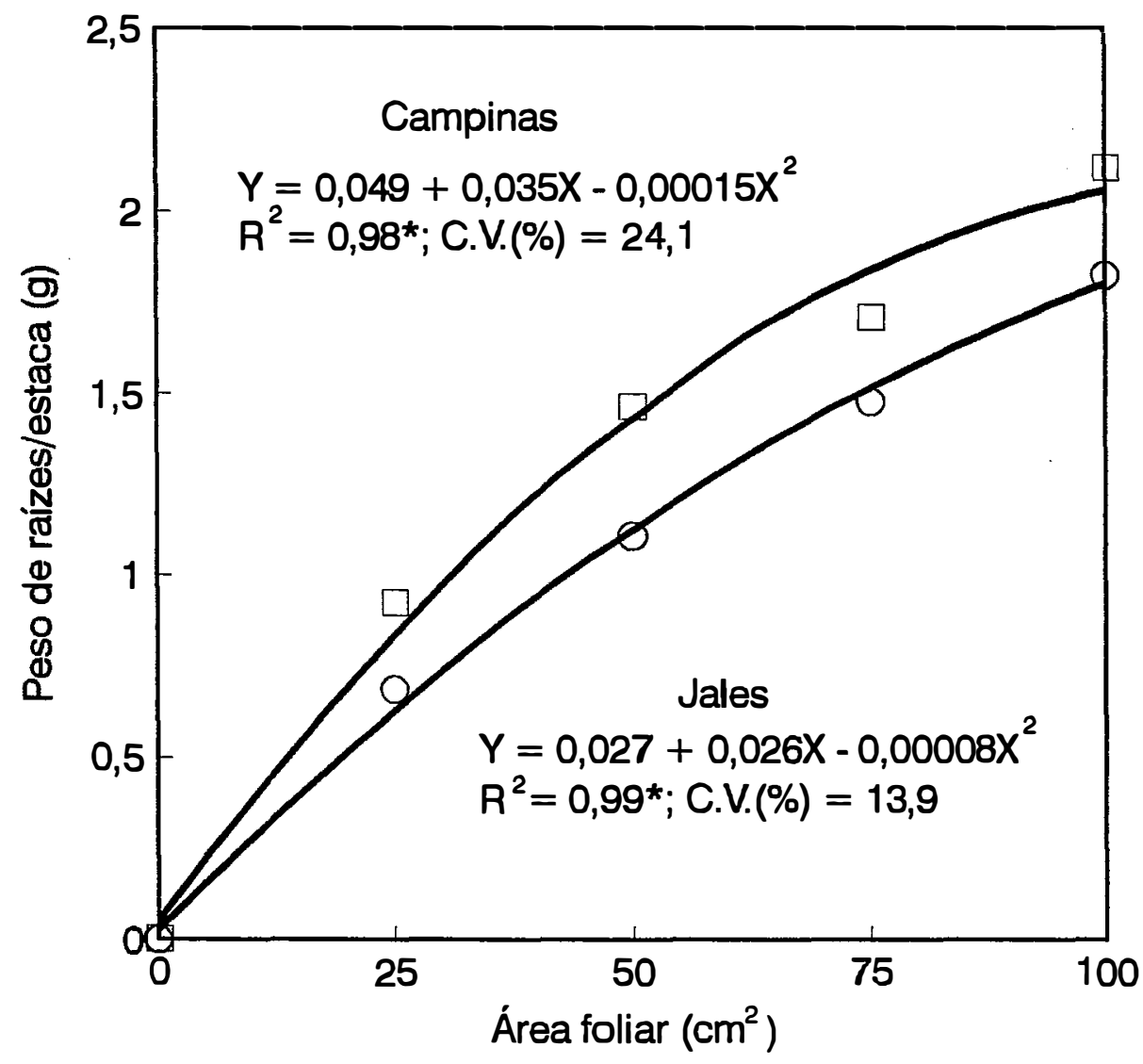

FIGURA 6. Efeito da área foliar sobre o peso (g) de raízes emitidas por estaca dos porta-enxertos 'Jales' e 'Campinas' (Experimento 4.2.4; apêndices 9 e 11). 


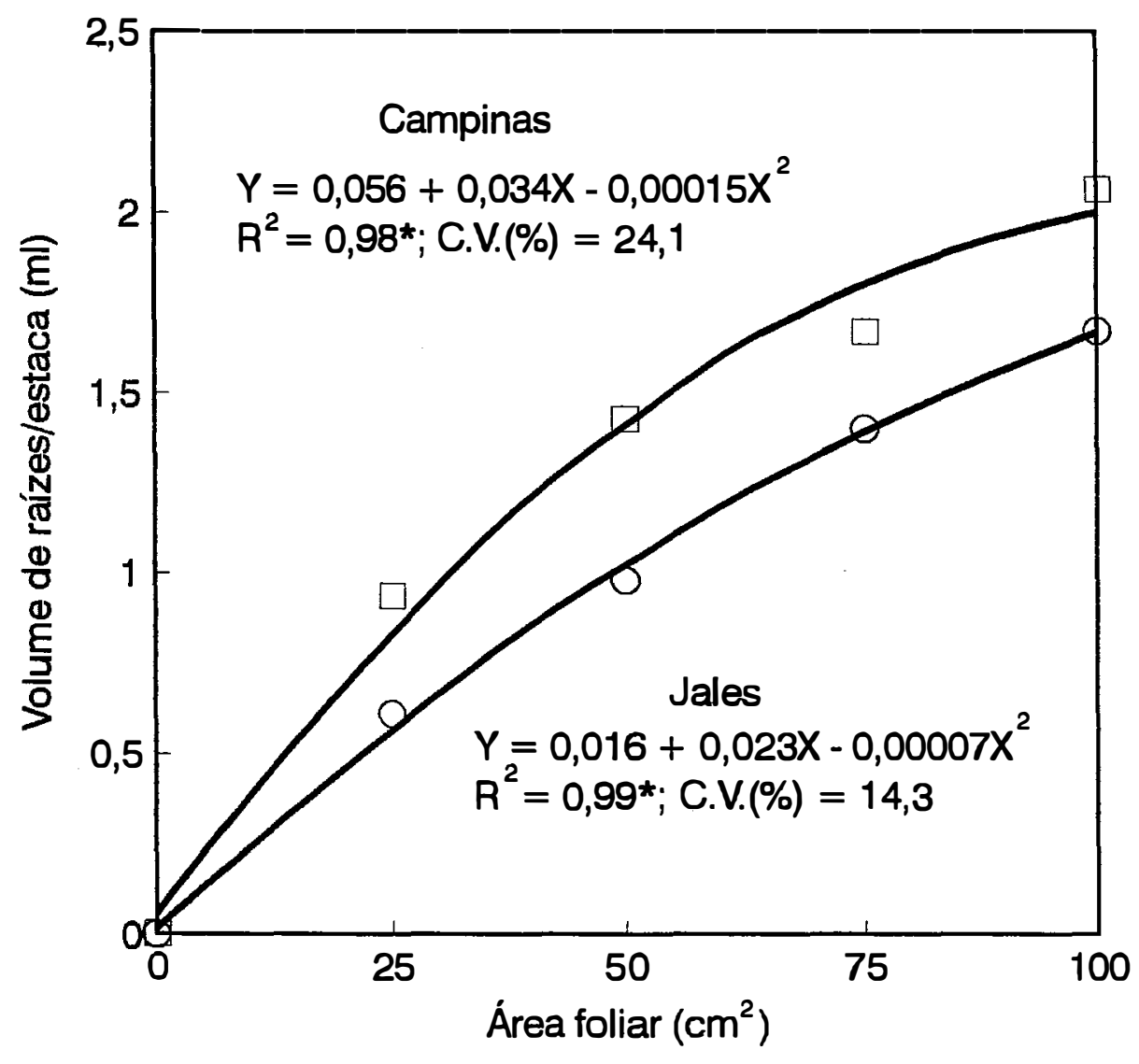

FIGURA 7. Efeito da área foliar sobre o volume (ml) de raizes emitidas por estaca dos porta-enxertos 'Jales' e 'Campinas' (Experimento 4.2.4; apêndices 9 e 11). 
4.2.5. Avaliação do crescimento de mudas dos porta-enxertos 'Tropical', 'Jales' e 'Campinas' obtidas por estaquia semilenhosa

A análise de variância entre os três porta-enxertos estudados apresentou significância estatística apenas para o comprimento das brotações das mudas (Apêndice 12).

A sobrevivência das mudas obtidas pela estaquia semilenhosa foi elevado e não diferiu entre os cultivares, ocorrendo perdas, embora não significativas, apenas com o 'Jales' (Tabela 10), o que demonstra boa tolerância ao transplante, pois as mudas foram levadas diretamente da câmara de nebulização para os sacos ao ar livre.

O 'Campinas' apresentou maior crescimento da brotação da estaca que atingiu em média $61,7 \mathrm{~cm}$, superior ao 'Jales' mas não diferiu do 'Tropical'. Entretanto, quando observado o peso da parte aérea, o peso do sistema radicular e o volume de raízes, não foram encontradas diferenças entre os porta-enxertos (Tabela 10).

Neste estádio de desenvolvimento as mudas apresentaram diâmetro da brotação inferior a $0,5 \mathrm{~cm}$, o que inviabiliza a sua imediata enxertia lenhosa, mas esta técnica permite a obtenção rápida de grande quantidade de mudas a partir de poucas matrizes. Este processo já é utilizado em outros países quando se dispõe de pouco material vegetativo (Alley, 1980) ou quando o sistema de produção de mudas envolve a enxertia verde, que consiste na união do garfo com um portaenxerto de mesma consistência e possuindo uma folha (Anaclerio et al., 1992). 
TABELA 10. Avaliação do desenvolvimento de mudas obtidas por estaquia semilenhosa dos porta-enxertos 'Tropical', 'Jales' e 'Campinas' (Experimento 4.2.5; apêndice 12).

\begin{tabular}{lcccccc}
\hline $\begin{array}{l}\text { Porta- } \\
\text { enxerto }\end{array}$ & $\begin{array}{c}\text { Sobrevi- } \\
\text { vência } \\
(\%)\end{array}$ & $\begin{array}{c}\text { Comprimento } \\
\text { da brotação } \\
(\mathrm{cm})\end{array}$ & $\begin{array}{c}\text { Diâmetro } \\
(\mathrm{mm})\end{array}$ & $\begin{array}{c}\text { Peso da } \\
\text { parte aérea } \\
(\mathrm{g})\end{array}$ & $\begin{array}{c}\text { Peso das } \\
\text { raizes } \\
(\mathrm{g})\end{array}$ & $\begin{array}{c}\text { Volume } \\
\text { das raizes } \\
(\mathrm{ml})\end{array}$ \\
\hline Campinas & $100,0 \mathrm{a} 1$ & $61,7 \mathrm{a}$ & $4,1 \mathrm{a}$ & $11,8 \mathrm{a}$ & $24,2 \mathrm{a}$ & $20,7 \mathrm{a}$ \\
Tropical & $100,0 \mathrm{a}$ & $53,3 \mathrm{ab}$ & $4,4 \mathrm{a}$ & $12,0 \mathrm{a}$ & $22,2 \mathrm{a}$ & $19,3 \mathrm{a}$ \\
Jales & $83,3 \mathrm{a}$ & $48,7 \mathrm{~b}$ & $4,8 \mathrm{a}$ & $13,0 \mathrm{a}$ & $20,9 \mathrm{a}$ & $18,5 \mathrm{a}$ \\
\hline C.V.(\%) & 9,3 & 7,2 & 7,9 & 12,9 & 10,6 & 14,4 \\
\hline
\end{tabular}

${ }^{1}$ Médias seguidas pela mesma letra não diferem significativamente pelo teste de Tukey ao nível de $5 \%$ de probabilidade.

\subsection{Experimentos de micropropagação}

4.3.1. Efeito da BAP na indução do crescimento de ápices meristemáticos dos porta-enxertos 'Jales' e 'Campinas'

$\mathrm{O}$ efeito das concentrações de BAP foi significativo para a porcentagem de explantes com crescimento e com folha aos 30 e 60 dias para os porta-enxertos 'Jales' (Apêndice 13) e 'Campinas' (Apêndice 14).

A porcentagem de ápices meristemáticos com crescimento apresentou um comportamento quadrático, aumentando com a concentração de BAP em ambos porta-enxertos aos 30 (Figura 8) e 60 dias (Figura 9). Esse comportamento era esperado pelo já bem conhecido efeito promotor do BAP sobre o desenvolvimento de meristemas de videira (Krul \& Mowbray, 1984; Passos et al., 1985). 


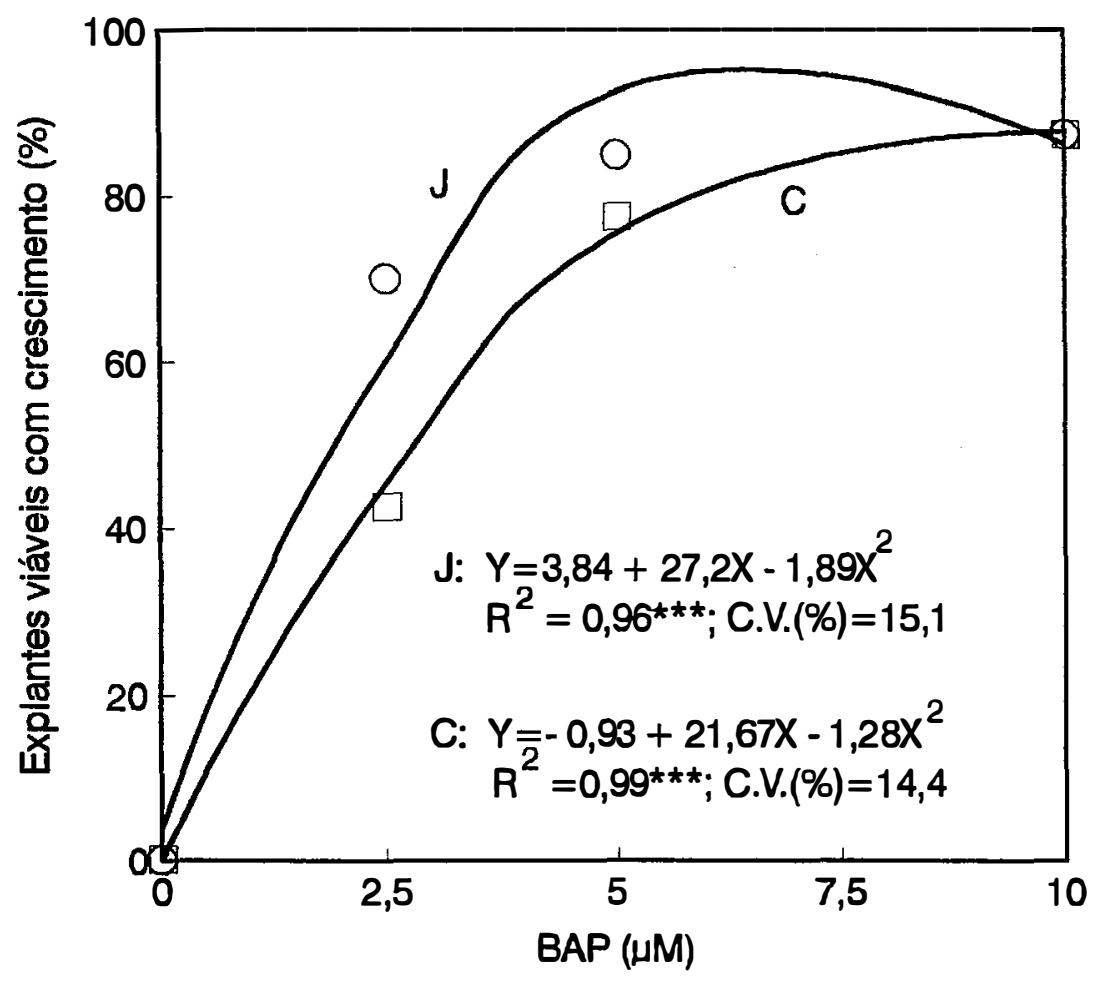

FIGURA 8. Efeito da concentração de BAP na porcentagem de ápices meristemáticos com crescimento dos porta-enxertos 'Jales' (J) e 'Campinas' (C) aos 30 dias após a instalação do experimento (Experimento 4.3.1; apêndices 13 e 14). 


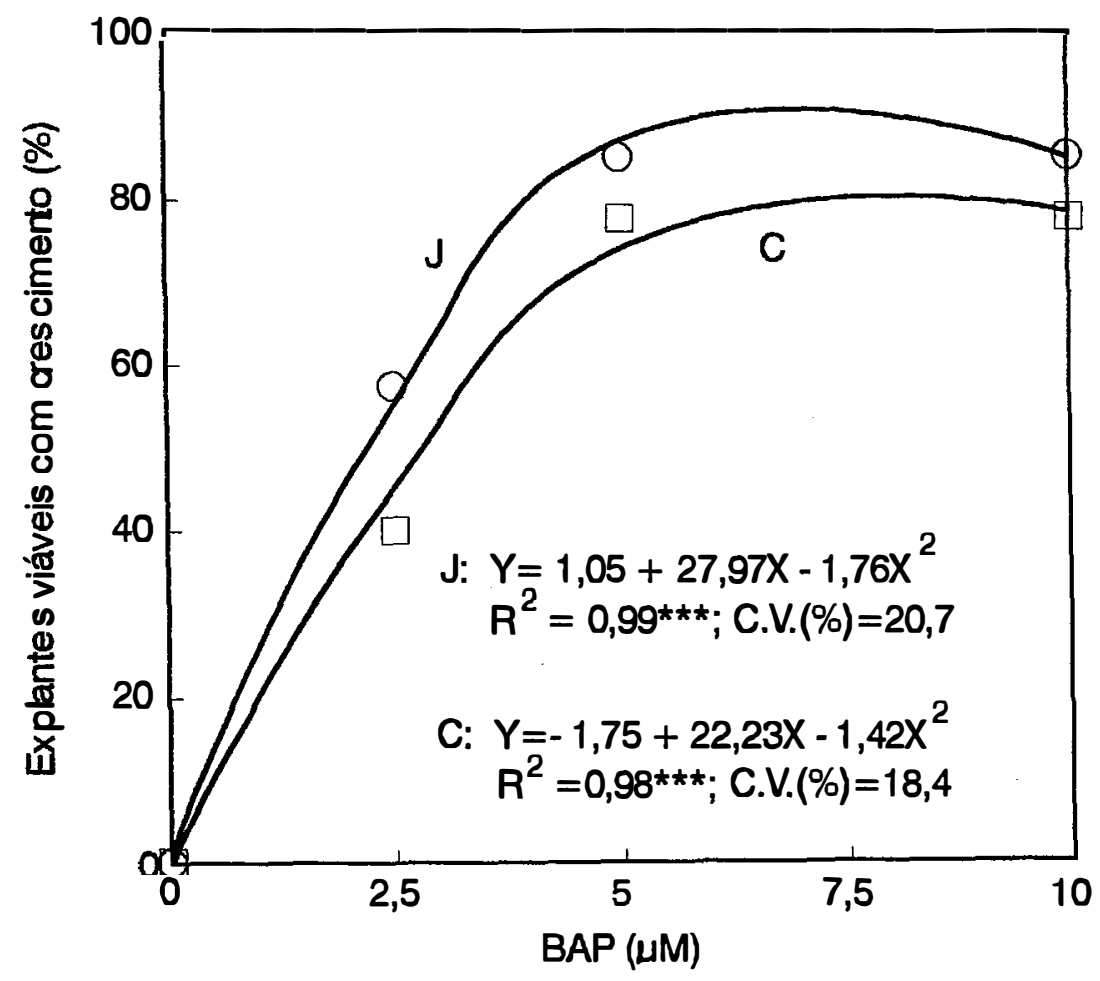

FIGURA 9. Efeito da concentração de BAP na porcentagem de ápices meristemáticos com crescimento dos porta-enxertos 'Jales' (J) e 'Campinas' (C) aos 60 dias após a instalação do experimento (Experimento 4.3.1.; apêndices 13 e 14). 
O máximo estímulo ao desenvolvimento dos ápices foi encontrado com os

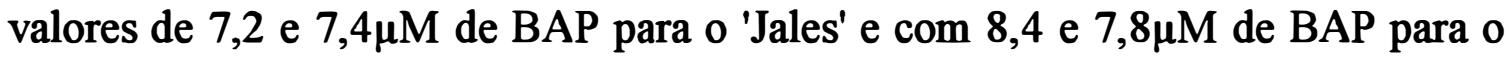
'Campinas', aos 30 e 60 dias, respectivamente. Esses valores são bastante próximos dos obtidos com diversos cultivares por Barlass \& Skene (1980a), Duran-Vila et al. (1988), Goussard (1982), Gray \& Fisher (1985) e Novák \& Juvová (1983), cujas concentrações utilizadas variaram de 5 a $10 \mu \mathrm{M}$ de BAP, o que corresponde a aproximadamente 1,1 a $2,2 \mathrm{mg} / \mathrm{L}$.

Alguns ápices permaneceram verdes ou com pequenas porções oxidadas até a última avaliação aos 60 dias, porém sem apresentar desenvolvimento. Isto também foi verificado com o cultivar A Dona (Passos et al., 1985). Talvez este fato tenha ocorrido devido ao pequeno tamanho dos explantes, já que quanto menor o ápice meristemático mais dificil é a sua regeneração (Koruza \& Jelaska, 1993).

Nem todos os explantes que apresentaram crescimento diferenciaram folhas, mas novamente o efeito da BAP foi evidente, encontrando-se regressões lineares significativas entre suas concentrações e a porcentagem de explantes com folhas diferenciadas para o 'Campinas' nas duas épocas avaliadas e regressões quadráticas para o 'Jales' (Figuras 10 e 11). Para ambos porta-enxertos a maior concentração utilizada de $\mathrm{BAP}, 10 \mu \mathrm{M}$, promoveu a melhor resposta. Este resultado coincide com o obtido por Barlass \& Skene (1980b) para os cultivares Cabernet Sauvignon e Thompson Seedless, cuja adição de $10 \mu \mathrm{M}$ de BAP ao meio de cultura foi ótima para promover o crescimento inicial de folhas a partir de ápices fragmentados e a subseqüente diferenciação de brotações adventícias destas folhas, processo já descrito por Barlass \& Skene (1978). 


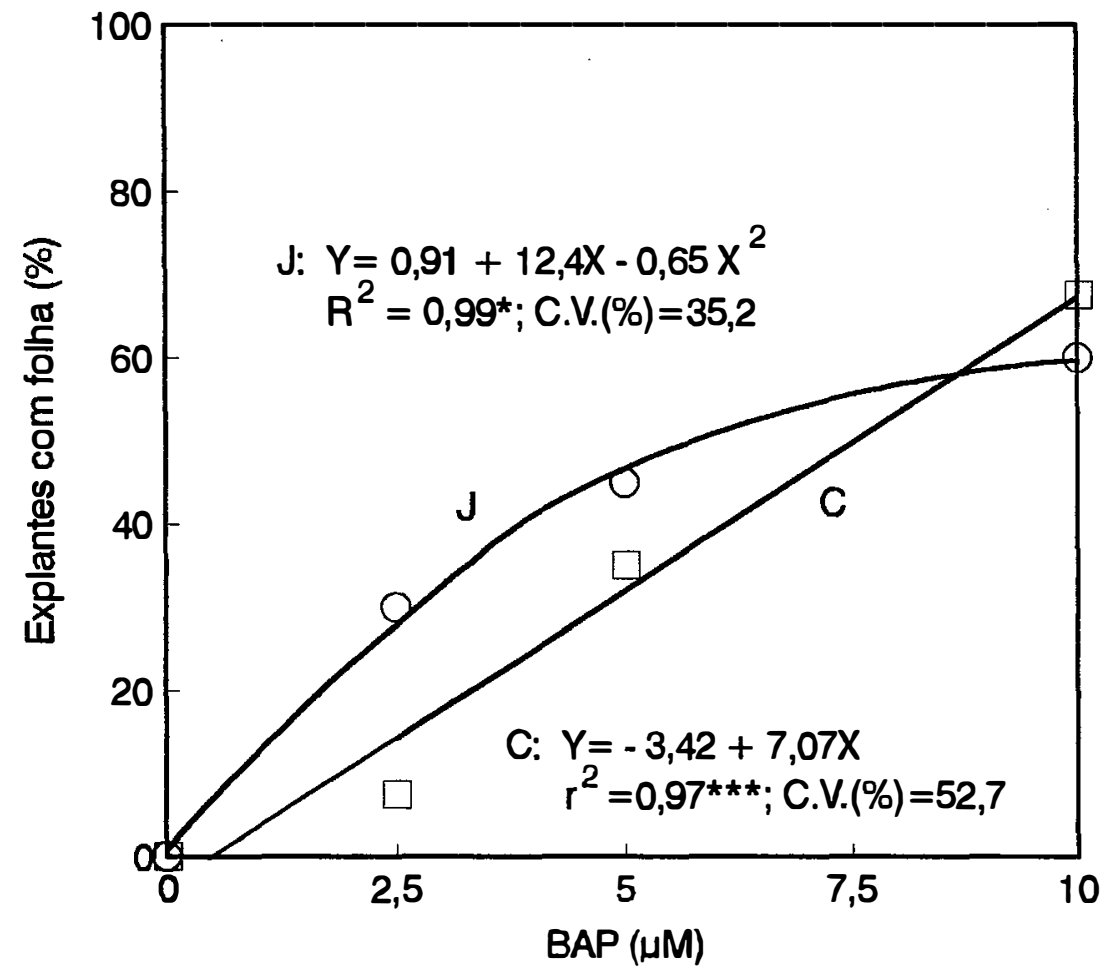

FIGURA 10. Efeito da concentração de BAP na porcentagem de ápices meristemáticos com folha dos porta-enxertos 'Jales' (J) e 'Campinas' (C) aos 30 dias após a instalação do experimento (Experimento 4.3.1; apêndices 13 e 14). 


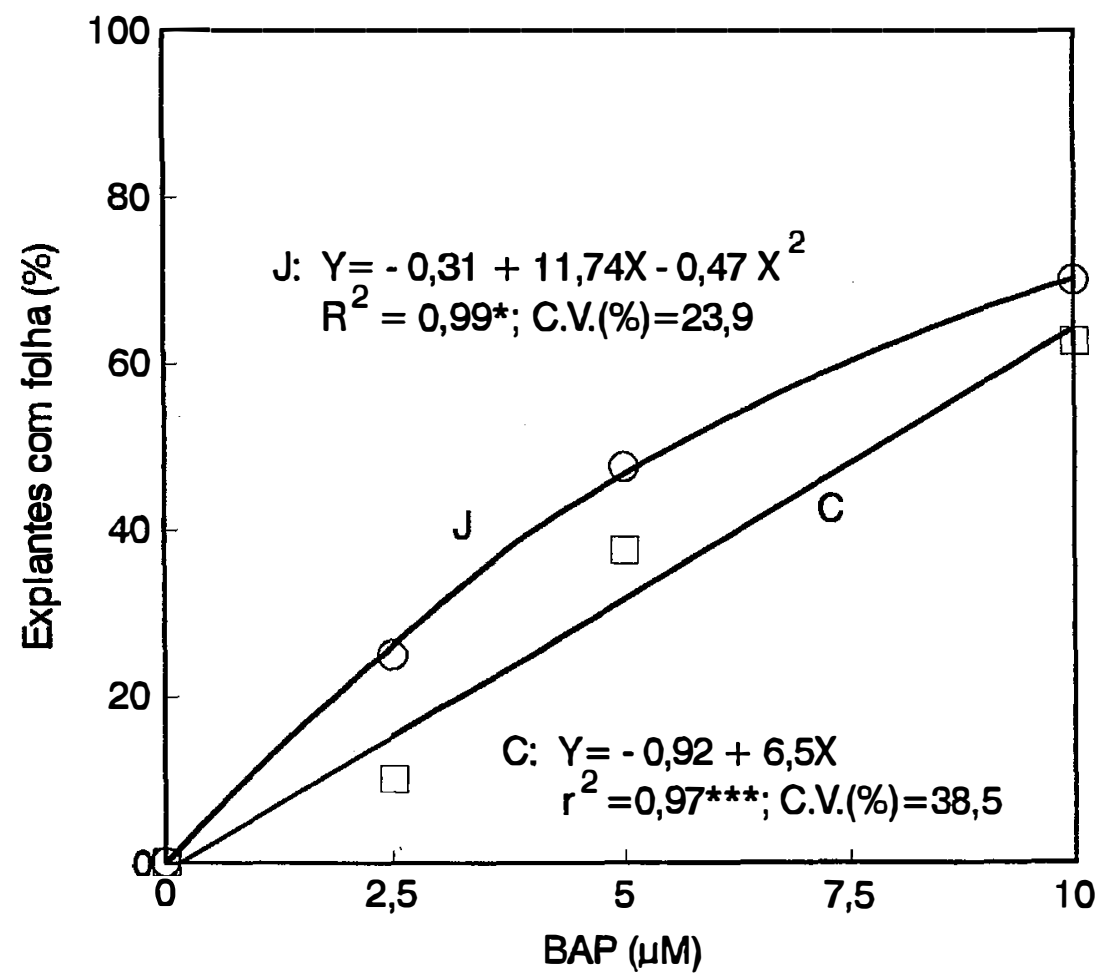

FIGURA 11. Efeito da concentração de BAP na porcentagem de ápices meristemáticos com folha dos porta-enxertos 'Jales' (J) e 'Campinas' (C) aos 60 dias após a instalação do experimento (Experimento 4.3.1; apêndices 13 e 14). 
De maneira geral, a porcentagem de explantes oxidados e contaminados foi baixa aos 30 dias, mas elevou-se um pouco aos 60 dias, sendo que a perda por oxidação de ápices meristemáticos do porta-enxerto 'Campinas' foi maior do que a do 'Jales' (Tabela 11).

\subsubsection{Efeito do tempo de permanência no meio de indução sobre o crescimento de ápices meristemáticos do porta-enxerto 'Campinas'}

A análise de variância para o efeito do tempo de permanência revelou significância estatística para todas as variáveis analisadas (Apêndice 15).

A porcentagem de ápices meristemáticos com crescimento aumentou com 0 passar do tempo no meio de cultura com $10 \mu \mathrm{M}$ de BAP, até o ponto máximo de 93,2\% observado aos 30 dias após o isolamento, quando passou a decrescer. A diminuição do número de explantes em desenvolvimento ocorreu pelo aumento da perda de explantes por oxidação, que atingiu $20 \%$ aos 42 dias (Figura 12).

Entretanto, o comportamento da porcentagem de explantes com folhas aumentou linearmente com o tempo (Figura 12). Estes explantes são os desejados nesta fase, pois estão com maior desenvolvimento e mais próximos de regenerar uma nova planta. Portanto, a permanência no meio de indução por até 42 dias foi favorável ao desenvolvimento dos explantes. Passos et al. (1985) também observaram que o desenvolvimento de meristemas do cultivar A Dona foi inicialmente lento, encontrando maior crescimento numa avaliação realizada cerca de 60 dias após o isolamento. Meristemas do cultivar Cabernet Sauvignon também apresentaram maior desenvolvimento e proliferação de novas brotações após 2 meses de cultivo (Duran-Vila et al., 1988). 
TABELA 11. Efeito da concentração de BAP na porcentagem de oxidação e contaminação de ápices meristemáticos dos porta-enxertos 'Jales' e 'Campinas' após 30 e 60 dias da instalação do experimento (Experimento 4.3.1).

\begin{tabular}{|c|c|c|c|c|c|c|c|c|}
\hline \multirow{3}{*}{$\begin{array}{l}\text { BAP } \\
(\mu \mathrm{M})\end{array}$} & \multicolumn{4}{|c|}{$\begin{array}{c}\text { Oxidação } \\
(\%)\end{array}$} & \multicolumn{4}{|c|}{$\begin{array}{c}\text { Contaminação } \\
(\%)\end{array}$} \\
\hline & \multicolumn{2}{|c|}{ Jales } & \multicolumn{2}{|c|}{ Campinas } & \multicolumn{2}{|c|}{ Jales } & \multicolumn{2}{|c|}{ Campinas } \\
\hline & 30 & 60 & 30 & 60 & 30 & 60 & 30 & 60 \\
\hline 0 & 5 & 5 & 5 & 22,5 & 0 & 2,5 & 5 & 7,5 \\
\hline 2,5 & 5 & 12,5 & 0 & 7,5 & 0 & 5 & 7,5 & 12,5 \\
\hline 5 & 0 & 0 & 2,5 & 2,5 & 0 & 7,5 & 5 & 7,5 \\
\hline 10 & 0 & 5 & 2,5 & 15 & 0 & 2,5 & 5 & 5 \\
\hline Média & 2,5 & 5,6 & 2,5 & 11,8 & 0 & 4,4 & 5,6 & 8,1 \\
\hline
\end{tabular}

\subsubsection{Efeito da BAP na indução do crescimento de segmentos nodais do porta-enxerto 'Jales'}

$A$ adição de BAP ao meio de cultura não provocou efeito significativo sobre a brotação e a oxidação dos segmentos nodais, mas afetou a formação de calo e o crescimento das gemas axilares (Apêndice 16).

O aumento da concentração de BAP induziu o crescimento das gemas axilares dos segmentos nodais até a concentração de $11,5 \mu \mathrm{M}$, estimada pela equação de regressão, quando passou a reduzir seu crescimento (Figura 13).

Concentrações superiores a $10 \mu \mathrm{M}$ deste regulador também apresentaram-se prejudiciais na micropropagação dos cultivares Summit (Lee \& Wetzstein, 1990) e Remaily Seedless (Chée \& Pool, 1985). O uso de concentrações muito elevadas 


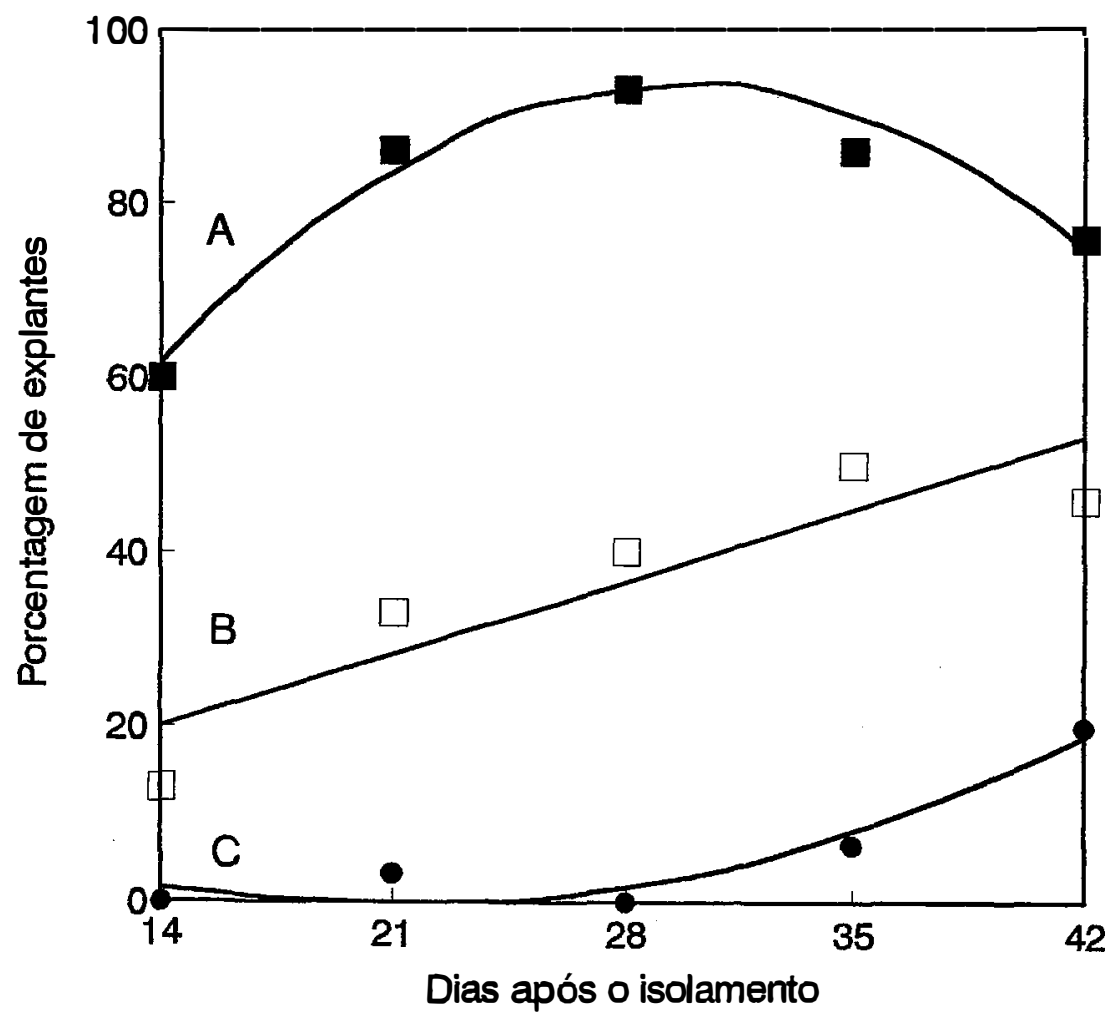

A) $Y=-19,33+7,55 X-0,12 X^{2} ; R^{2}=0,95^{\star \star *}$

B) $Y=3,33+1,19 X ; r^{2}=0,82 * *$

C) $Y=18,67-1,83 X+0,043 X^{2} ; R^{2}=0,91 * *$

FIGURA 12. Efeito do tempo de permanência em meio MS com $10 \mu \mathrm{M}$ de BAP sobre a porcentagem de explantes com crescimento (A), porcentagem de explantes com folha (B) e porcentagem de explantes oxidados $(C)$ do porta-enxerto 'Campinas' (Experimento 4.3.2; apêndice 15). 


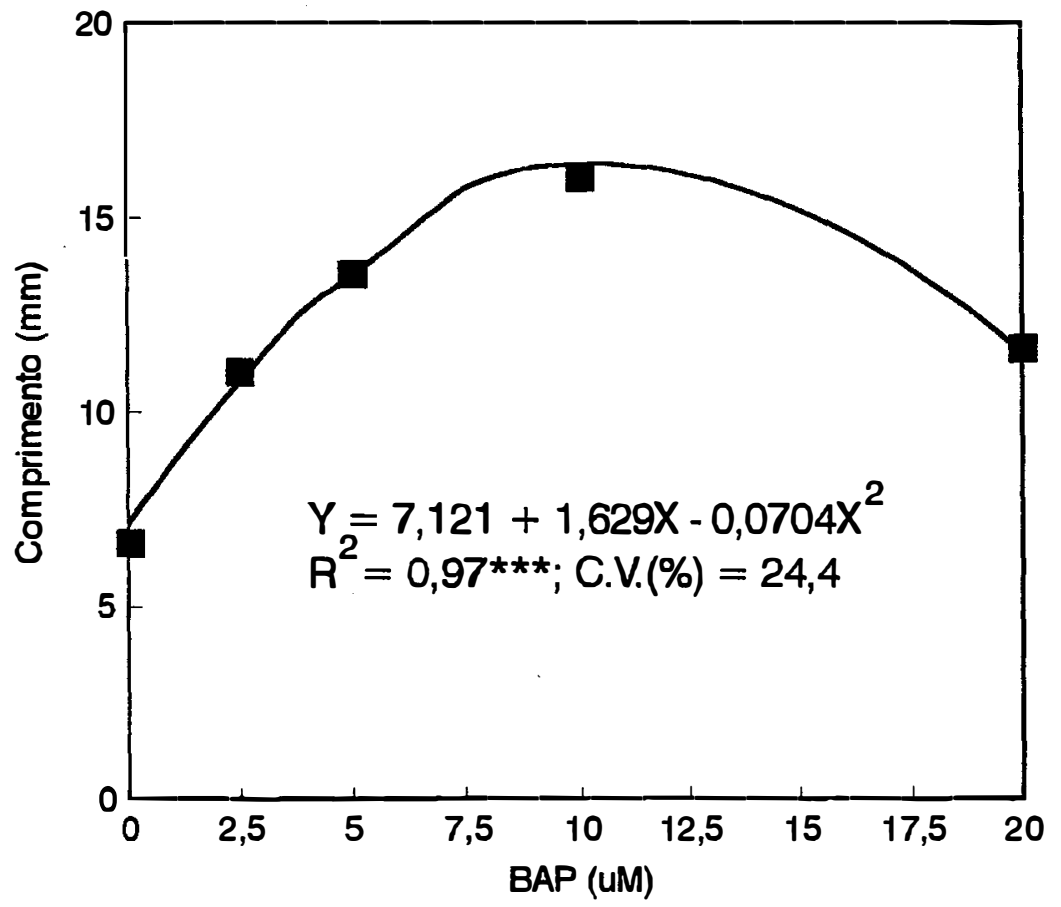

FIGURA 13. Efeito de concentrações de BAP no crescimento das gemas axilares de segmentos nodais do porta-enxerto 'Jales' após 40 dias (Experimento 4.3.3; apêndice 16). 
de BAP causam a formação de brotações anormais e vitrificadas (Harris \& Stevenson, 1982), podendo também reduzir a proliferação e o crescimento das brotações e provocar a ocorrência de altos índices de mortalidade (Lee \& Wetzstein, 1990).

Peixoto et al. (1984), trabalhando com o porta-enxerto '1103 Paulsen', obtiveram as maiores brotações utilizando $0,5 \mathrm{mg} / \mathrm{L}$ de BAP e concentrações superiores a esta aumentaram a vitrificação das brotações.

A brotação dos segmentos nodais foi alta, $86 \%$, em meio sem regulador, mas seu crescimento foi muito pequeno. Neste caso também não houve a formação de calo na base dos explantes, que apenas ocorreu com a adição de BAP ao meio de cultura (Tabela 12).

TABELA 12. Efeito de concentrações de BAP na indução da brotação da gema axilar, na oxidação e na formação de calo em segmentos nodais do porta-enxerto 'Jales' após 40 dias (Experimento 4.3.3; apêndice 16).

\begin{tabular}{lccc}
\hline $\begin{array}{l}\text { BAP } \\
(\mu \mathrm{M})\end{array}$ & $\begin{array}{c}\text { Brotação } \\
(\%)\end{array}$ & $\begin{array}{c}\text { Oxidação }^{1} \\
(\%)\end{array}$ & $\begin{array}{c}\text { Calo } \\
(\%)\end{array}$ \\
\hline 0 & $86,1 \mathrm{a}^{2}$ & $12,5 \mathrm{a}$ & $0,0 \mathrm{c}$ \\
2,5 & $93,7 \mathrm{a}$ & $28,3 \mathrm{a}$ & $32,8 \mathrm{~b}$ \\
5 & $100,0 \mathrm{a}$ & $14,0 \mathrm{a}$ & $95,8 \mathrm{a}$ \\
10 & $100,0 \mathrm{a}$ & $10,0 \mathrm{a}$ & $100,0 \mathrm{a}$ \\
20 & $100,0 \mathrm{a}$ & $31,9 \mathrm{a}$ & $96,8 \mathrm{a}$ \\
\hline C.V.(\%) & 9,7 & 75,3 & 9,2 \\
\hline
\end{tabular}

${ }^{1}$ Dados transformados em arc sen $(\mathrm{x} / 100)^{1 / 2}$

2Médias seguidas pela mesma letra não diferem significativamente pelo teste de Tukey ao nível de 5\% de probabilidade. 


\subsubsection{Efeito da posição do segmento nodal da brotação das estacas} sobre o crescimento dos explantes do porta-enxerto 'Jales'

A análise de variância do efeito da posição do segmento nodal apenas revelou significância estatística para o comprimento das brotações, sendo este efeito melhor representado pela regressão linear (Apêndice 17).

A porcentagem de explantes contaminados, oxidados e com calo na base não diferiram entre as posições (Tabela 13).

$\mathrm{O}$ crescimento das brotações dos segmentos nodais foi maior, à medida que se utilizou segmentos mais próximos da base das brotações das estacas (Figura 14). Estes segmentos mais basais apresentaram-se maiores e mais lignificados do que os apicais, o que pode ter contribuído com maiores reservas nutricionais para o crescimento das gemas axilares.

TABELA 13. Efeito da posição do segmento nodal da brotação das estacas sobre a contaminação, oxidação e formação de calo dos explantes do porta-enxerto 'Jales' (Experimento 4.3.4; apêndice 17).

\begin{tabular}{lccc}
\hline Posição & Contaminação ${ }^{1}(\%)$ & Oxidação $^{2}(\%)$ & Calo (\%) \\
\hline 1 & $4,1 \mathrm{a}^{3}$ & $24,9 \mathrm{a}$ & $75,0 \mathrm{a}$ \\
2 & $7,1 \mathrm{a}$ & $20,8 \mathrm{a}$ & $91,6 \mathrm{a}$ \\
3 & $3,6 \mathrm{a}$ & $19,6 \mathrm{a}$ & $85,0 \mathrm{a}$ \\
4 & $4,1 \mathrm{a}$ & $12,4 \mathrm{a}$ & $88,7 \mathrm{a}$ \\
5 & $12,5 \mathrm{a}$ & $18,7 \mathrm{a}$ & $75,0 \mathrm{a}$ \\
6 & $12,5 \mathrm{a}$ & $18,7 \mathrm{a}$ & $87,5 \mathrm{a}$ \\
7 & $6,2 \mathrm{a}$ & $37,5 \mathrm{a}$ & $75,0 \mathrm{a}$ \\
\hline C.V.(\%) & 89,2 & 67,7 & 44,5 \\
\hline
\end{tabular}

${ }^{1}$ Dados transformados em $(x+1)^{1 / 2}$

2Dados transformados em arc sen $(x / 100)^{1 / 2}$

${ }^{3}$ Médias seguidas pela mesma letra não diferem significativamente pelo teste de Tukey ao nível de $5 \%$ de probabilidade. 


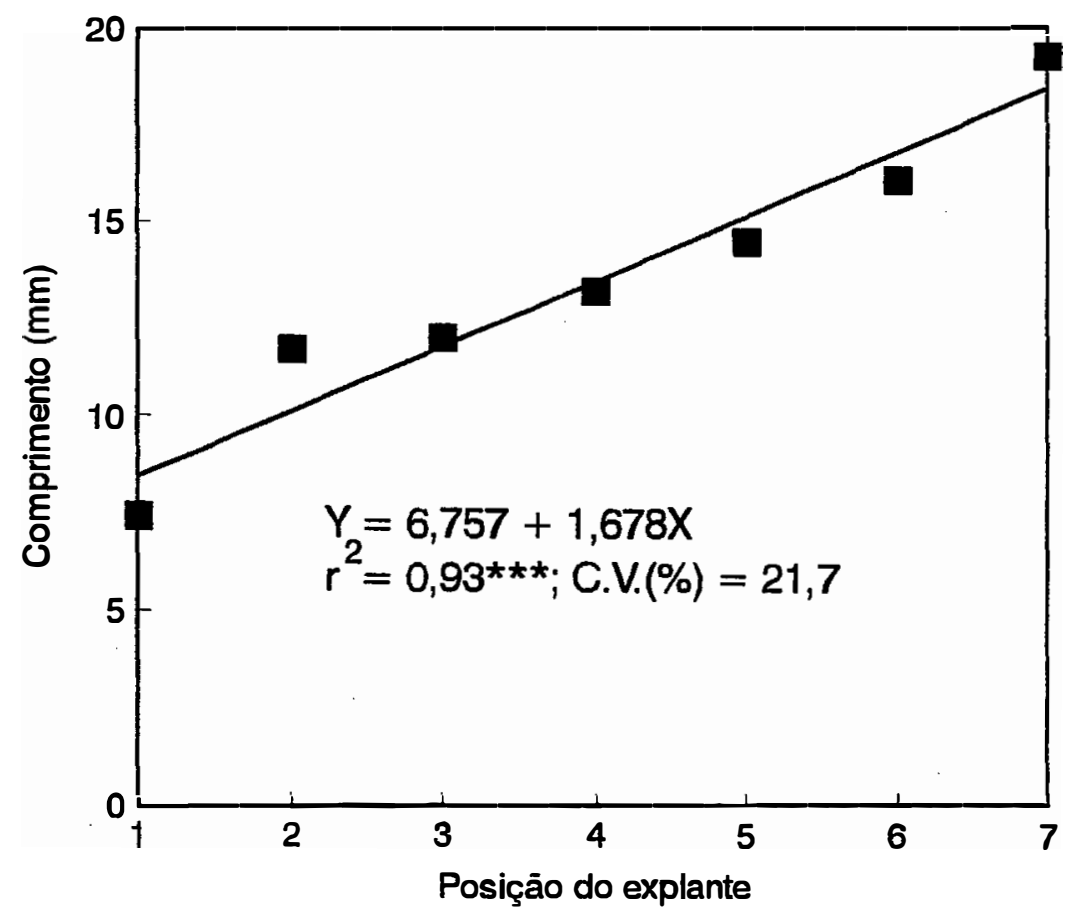

FIGURA 14. Efeito da posição do segmento nodal da brotação das estacas sobre o crescimento da gema axilar dos explantes do porta-enxerto 'Jales' (Experimento 4.3.4; apêndice 17). 


\subsubsection{Efeito de diferentes meios de cultura no crescimento do porta-enxerto 'Jales'}

O efeito dos meios de cultura foi significativo para todas as variáveis analisadas, com exceção apenas para o comprimento médio dos entrenós (Apêndice 18).

Os meios de cultura GZ(64) e GZ(90) apresentaram elevada oxidação, menor crescimento da brotação e menor número de folhas por planta, não diferindo do meio MS (Tabela 14).

O meio MS com a concentração normal de sais também foi prejudicial para a porcentagem de enraizamento e para o número de raízes emitidas por explante, sendo inferior a todos os outros meios (Tabela 14).

Os melhores resultados foram obtidos com os meios $\mathrm{NN}$ e $\mathrm{MS} / 2$ que não diferiram significativamente em nenhum parâmetro analisado, apesar do meio MS/2 apresentar valores superiores ao NN (Tabela 14). Este comportamento deve ter ocorrido devido à grande semelhança na composição química destes meios de cultura (Tabela 3 ).

Com o meio MS/2 foram obtidas 3,9 folhas por brotação, o que representa, em termos de taxa de multiplicação, praticamente 4 novas plantas em 33 dias.

A redução na concentração de macro e micronutrientes do meio MS é comum na micropropagação de videiras (Blazina et al., 1991a; Botti et al., 1993; Ciccotti, 1982; Fanizza et al., 1984; Harris \& Stevenson, 1982). Geralmente são utilizadas concentrações reduzidas a 3/4, 1/2 e 1/4 do meio básico de MS, principalmente na fase de enraizamento das brotações (Botti et al., 1993; Ciccotti, 1982; Harris \& Stevenson, 1982). 
TABELA 14. Efeito de diferentes meios de cultura sobre o crescimento do portaenxerto 'Jales' (Experimento 4.3.5; apêndice 18).

\begin{tabular}{lcccccc}
$\begin{array}{l}\text { Meios de } \\
\text { cultura }\end{array}$ & $\begin{array}{c}\text { Oxidação } \\
(\%)^{1}\end{array}$ & $\begin{array}{c}\text { Enraizamento } \\
(\%)^{1}\end{array}$ & $\begin{array}{c}\text { Número de } \\
\text { raízes/ } \\
\text { explante }\end{array}$ & $\begin{array}{c}\text { Comprimento } \\
\text { da brotação } \\
(\mathrm{mm})\end{array}$ & $\begin{array}{c}\text { Comprimento } \\
\text { dos entrenós } \\
(\mathrm{mm})\end{array}$ & $\begin{array}{c}\text { Número de } \\
\text { folhas/ } \\
\text { brotação }\end{array}$ \\
\hline $\mathrm{MS} / 2$ & $5,0 \mathrm{~b}^{2}$ & $35,0 \mathrm{a}$ & $2,8 \mathrm{a}$ & $21,1 \mathrm{a}$ & $5,3 \mathrm{a}$ & $3,9 \mathrm{a}$ \\
$\mathrm{NN}$ & $10,0 \mathrm{~b}$ & $40,0 \mathrm{a}$ & $2,0 \mathrm{a}$ & $18,5 \mathrm{a}$ & $5,3 \mathrm{a}$ & $3,5 \mathrm{a}$ \\
$\mathrm{MS}$ & $17,5 \mathrm{ab}$ & $2,5 \mathrm{~b}$ & $1,0 \mathrm{~b}$ & $11,4 \mathrm{~b}$ & $5,2 \mathrm{a}$ & $2,1 \mathrm{~b}$ \\
$\mathrm{GZ}(90)$ & $15,0 \mathrm{ab}$ & $60,0 \mathrm{a}$ & $2,1 \mathrm{a}$ & $7,8 \mathrm{~b}$ & $4,9 \mathrm{a}$ & $1,6 \mathrm{~b}$ \\
$\mathrm{GZ}(64)$ & $32,5 \mathrm{a}$ & $37,5 \mathrm{a}$ & $2,3 \mathrm{a}$ & $6,3 \mathrm{~b}$ & $3,9 \mathrm{a}$ & $1,5 \mathrm{~b}$ \\
\hline $\mathrm{C}$.V.(\%) & 41,1 & 24,9 & 21,1 & 20,4 & 15,5 & 21,7 \\
\hline 1Dados transformados em arc sen (x/100) & & &
\end{tabular}

\subsubsection{Efeito do tamanho da folha do explante durante o subcultivo na multiplicação do porta-enxerto 'Jales'}

A análise de variância para o efeito do tamanho da folha foi significativa para todas as variáveis analisadas (Apêndice 19).

A presença da folha foi muito importante para o desenvolvimento do explante. Os segmentos nodais sem folha apresentaram-se significativamente inferiores aos segmentos com folha em todas as variáveis analisadas, com baixo enraizamento (20\%), pouca brotação da gema axilar $(26,7 \%)$ e crescimento insignificante. Já os segmentos com folha apresentaram $100 \%$ de explantes com brotação, elevado enraizamento e bom crescimento da gema axilar (Tabela 15). 
TABELA 15. Efeito do tamanho da folha do explante na multiplicação do portaenxerto 'Jales' (Experimento 4.3.6; apêndice 19).

\begin{tabular}{lccccc}
\hline Tamanho & $\begin{array}{c}\text { Comprimento } \\
\text { da brotação } \\
(\mathrm{cm})\end{array}$ & $\begin{array}{c}\text { Enraizamento } \\
(\%)\end{array}$ & $\begin{array}{c}\text { Brotação } \\
(\%)\end{array}$ & $\begin{array}{c}\text { Número de } \\
\text { folhas/ } \\
\text { brotação }\end{array}$ & $\begin{array}{c}\text { Número de } \\
\text { raizes/ } \\
\text { planta }\end{array}$ \\
\hline Sem folha & $0,2 \mathrm{c}^{1}$ & $20,0 \mathrm{~b}$ & $26,7 \mathrm{~b}$ & $0,7 \mathrm{~b}$ & $0,5 \mathrm{~b}$ \\
Pequena & $2,3 \mathrm{~b}$ & $93,3 \mathrm{a}$ & $100,0 \mathrm{a}$ & $3,3 \mathrm{a}$ & $1,8 \mathrm{a}$ \\
Média & $2,7 \mathrm{ab}$ & $100,0 \mathrm{a}$ & $100,0 \mathrm{a}$ & $3,4 \mathrm{a}$ & $2,5 \mathrm{a}$ \\
Grande & $3,1 \mathrm{a}$ & $100,0 \mathrm{a}$ & $100,0 \mathrm{a}$ & $3,7 \mathrm{a}$ & $2,3 \mathrm{a}$ \\
\hline C.V.(\%) & 8,8 & 14,7 & 7,1 & 9,7 & 18,9 \\
\hline
\end{tabular}

${ }^{1}$ Médias seguidas pela mesma letra não diferem significativamente pelo teste de Tukey ao nível de $5 \%$ de probabilidade.

Novák \& Juvová (1983) também observaram que a remoção das folhas dos explantes afetou negativamente o enraizamento do porta-enxerto 'André', mesmo em meio com $0,1 \mu \mathrm{M}$ de BAP. Este efeito prejudicial da retirada das folhas dos explantes também ocorreu com o cultivar Remaily Seedless, reduzindo a porcentagem de brotações com pelo menos três nós, o número de nós por brotação e o número total de nós por explante (Chée \& Pool, 1989).

Os diferentes tamanhos de folha diferiram significativamente apenas quanto ao comprimento da brotação da gema axilar, onde os explantes com folhas grandes $( \pm 1,5 \mathrm{~cm}$ de diâmetro) foram superiores aos com folhas pequenas $( \pm 0,5 \mathrm{~cm}$ de diâmetro), mas não diferiram dos com folhas médias ( $\pm 1 \mathrm{~cm}$ de diâmetro) (Tabela 15).

Os explantes com folhas grandes e médias também apresentaram maior porcentagem de enraizamento, maior número de folhas por brotação e maior 
número de raízes por planta do que os com folhas pequenas, porém estas diferenças não foram significativas (Tabela 15).

O subcultivo de explantes com folha demonstrou ser indispensável para a multiplicação do porta-enxerto 'Jales', possivelmente pela produção de substâncias necessárias para o enraizamento e crescimento através da fotossíntese, que ocorre in vitro, apesar de sofrer uma redução em condições heterotróficas (Galzy \& Compan, 1992), principalmente porque ao meio de cultura utilizado para a multiplicação neste experimento não foram adicionados reguladores de crescimento. Este fato assemelha-se com o que ocorre na estaquia semilenhosa (Davis, 1988), onde a presença das folhas nas estacas é importante como fonte de auxinas e carboidratos para a formação adventícia de raízes.

\subsubsection{Efeito da posição do explante durante o subcultivo na multiplicação do porta-enxerto 'Jales'}

A análise de variância para o efeito da posição do explante foi significativa para o comprimento da brotação, porcentagem de enraizamento e porcentagem de brotação, sendo verificadas regressões quadráticas significativas para as três variáveis (Apêndice 20).

A posição do explante não afetou o número de folhas e o número de raízes emitidas por planta (Tabela 16).

Através das curvas de regressão observou-se que o primeiro segmento abaixo do ápice apresentou-se próximo aos pontos de máximo comprimento da brotação (Figura 15), porcentagem de enraizamento e de brotação (Figura 16). Os menores valores encontrados com a porção apical podem estar associados ao 
TABELA 16. Efeito da posição do explante na multiplicação do porta-enxerto 'Jales' (Experimento 4.3.7; apêndice 20).

\begin{tabular}{lcc}
\hline Posição & $\begin{array}{c}\text { Número de } \\
\text { folhas/brotação }\end{array}$ & $\begin{array}{c}\text { Número de } \\
\text { raízes/planta }\end{array}$ \\
\hline 1 (ápice) & $3,3 \mathrm{a}^{1}$ & $2,0 \mathrm{a}$ \\
$2\left(1^{\circ}\right.$ segmento) & $3,2 \mathrm{a}$ & $1,9 \mathrm{a}$ \\
$3\left(2^{\circ}\right.$ segmento) & $3,4 \mathrm{a}$ & $2,1 \mathrm{a}$ \\
$4\left(3^{\circ}\right.$ segmento) & $2,9 \mathrm{a}$ & $1,8 \mathrm{a}$ \\
\hline C.V.(\%) & 11,1 & 21,3 \\
\hline
\end{tabular}

${ }_{1}$ Médias seguidas pela mesma letra não diferem significativamente pelo teste de Tukey ao nível de $5 \%$ de probabilidade.

menor tamanho da folha junto ao ápice, ainda não totalmente expandida, pois a área foliar é importante para o crescimento das brotações, como já comprovado no ítem 4.3.6.

Já o decréscimo destes parâmetros com o uso de posições mais basais dos explantes, provavelmente não foi relacionado com a área foliar, já que o tamanho das folhas nestas posições foram muito semelhantes. Possivelmente o balanço interno hormonal nas posições inferiores seja menos favorável ao enraizamento e crescimento, talvez por um menor conteúdo de auxinas nestas regiões, devido ao gradiente de concentração formado pelo seu transporte polar basípeto (Goldsmith, 1966). 


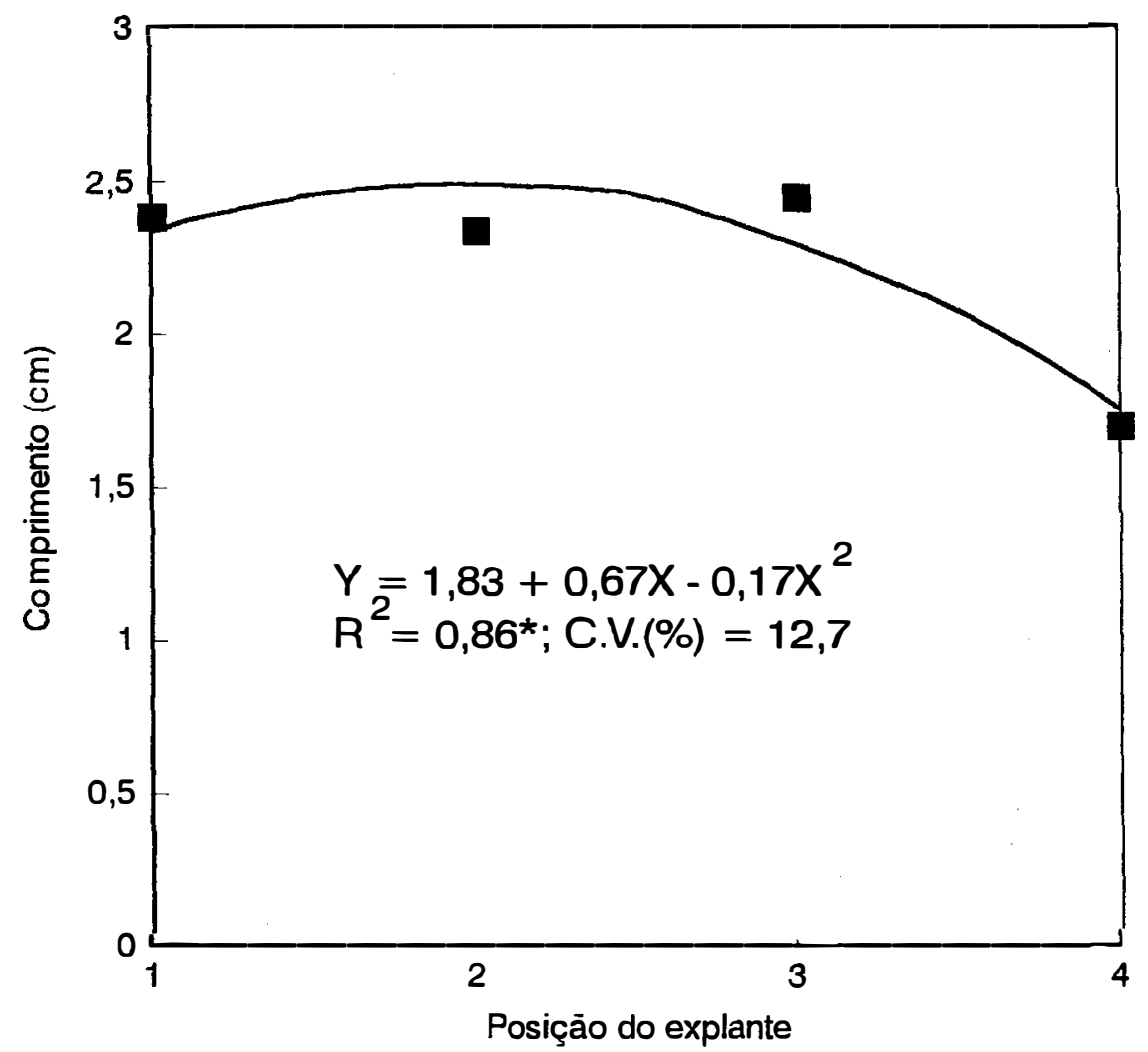

FIGURA 15. Efeito da posição do explante sobre o crescimento da brotação do porta-enxerto 'Jales' (Experimento 4.3.7; apêndice 20). 


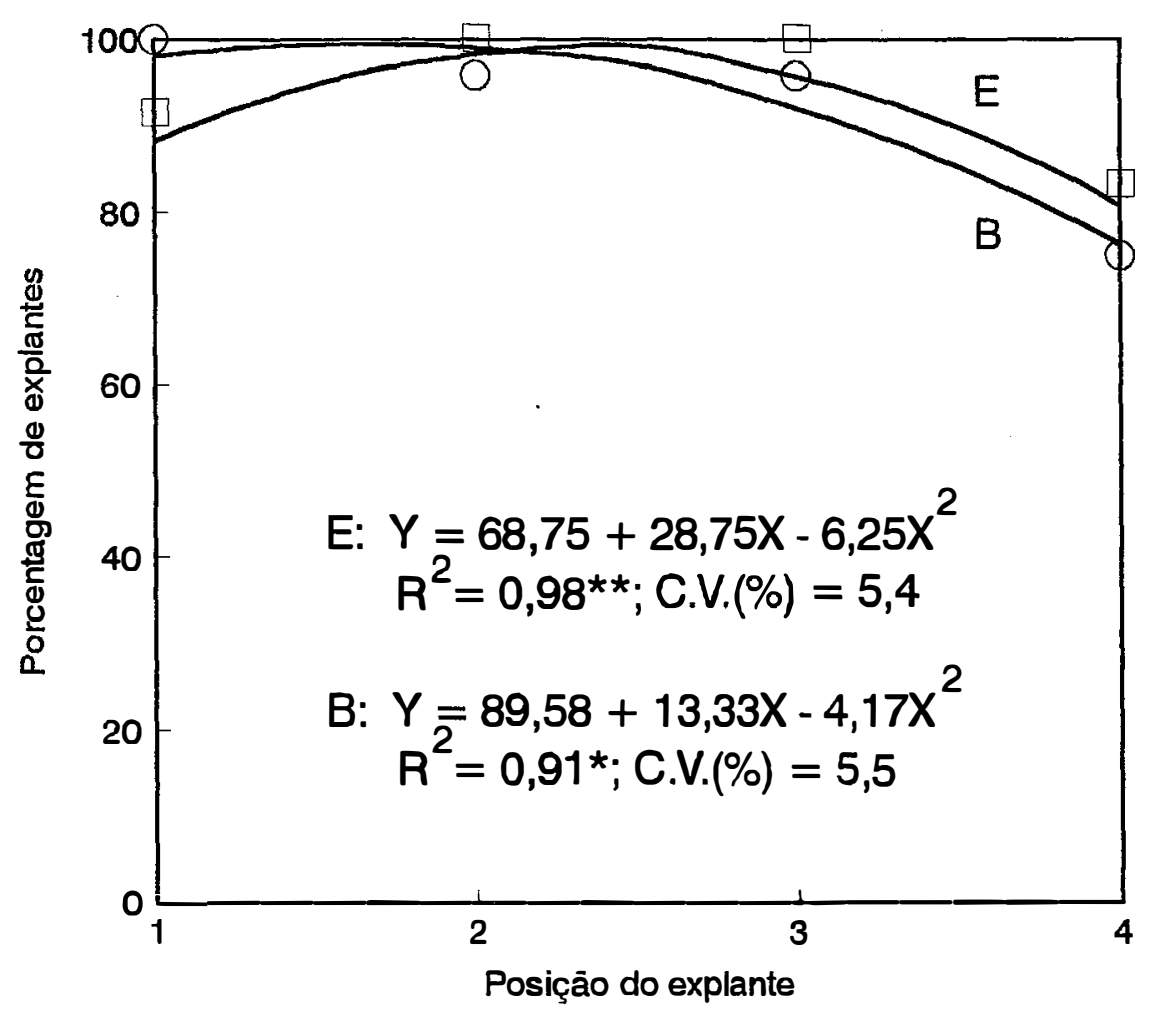

FIGURA 16. Efeito da posição do explante sobre a porcentagem de enraizamento (E) e brotação (B) dos segmentos nodais do porta-enxerto 'Jales' (Experimento 4.3.7; apêndice 20). 
4.3.8. Efeito de diferentes formas de aclimatização na sobrevivência das plantas do porta-enxerto 'Jales'

O efeito das formas de aclimatização foi significativo para a sobrevivência das plantas micropropagadas (Apêndice 21).

A aclimatização das plantas em recipientes fechados por 3 semanas, mesmo dentro da câmara de nebulização, proporcionou $100 \%$ de sobrevivência, enquanto nos recipientes abertos foi de $92,5 \%$ (Tabela 17). De qualquer forma, a sobrevivência foi alta, concordando com os resultados de Blazina et al. (1991b), Galzy (1964) e Lewandowski (1991) para diversos outros cultivares de videira.

O uso de recipientes fechados apresentou elevada sobrevivência na aclimatização do cultivar de videira Arka Neelamani, sendo obtidos melhores resultados simplesmente com a utilização de pequenos sacos plásticos fechados na parte superior por um período de três semanas, do que com potes plásticos comerciais específicos para este fim (Ravindra \& Thomas, 1995). Este tipo de aclimatização evitou a passagem por diversas fases para redução gradativa da umidade, como utilizado por Lewandowski (1991).

Após a abertura dos recipientes as plantas permaneceram em média por mais 4 semanas na câmara de nebulização, quando foram transferidas para os recipientes ao ar livre. O processo completo de micropropagação dos portaenxertos 'Jales' e 'Campinas' pode ser observado nas Figuras 17 e 18, respectivamente. 
TABELA :7. Efeito de diferentes formas de aclimatização na sobrevivência das plantas do porta-enxerto 'Jales' (Experimento 4.3.8; apêndice 21).

\begin{tabular}{lc}
\hline Recipientes & Sobrevivência (\%) \\
\hline Fechados & $100,0 \mathrm{a}^{1}$ \\
Abertos & $92,5 \mathrm{~b}$ \\
\hline C.V.(\%) & 3,6 \\
\hline
\end{tabular}

${ }^{1}$ Médias seguidas pela mesma letra não diferem significativamente pelo teste de Tukey ao nível de $5 \%$ de probabilidade.

4.4. Comparação do desenvolvimento aéreo e radicular em recipientes de plantas obtidas por estaquia lenhosa e micropropagação dos porta-enxertos 'Jales' e 'Campinas'

A análise de variância revelou significância estatística para todas as variáveis testadas (Apêndices 22 e 23).

As plantas obtidas de estacas dos porta-enxertos 'Jales' e 'Campinas' apresentaram desenvolvimento superior às obtidas por micropropagação e praticamente não diferiram entre si. Apenas quanto ao peso do sistema radicular, o 'Jales' foi significativamente superior ao 'Campinas' (Tabelas 18 e 19).

As plantas micropropagadas apresentaram-se menos ramificadas do que as obtidas por estaca, como pode-se observar na Tabela 18, onde o comprimento total das brotações emitidas pelas plantas oriundas de estacas foi superior a $3 \mathrm{~m}$, enquanto a brotação principal media menos de $1 \mathrm{~m}$. Já nas plantas micropropagadas esta diferença foi bem menor. 


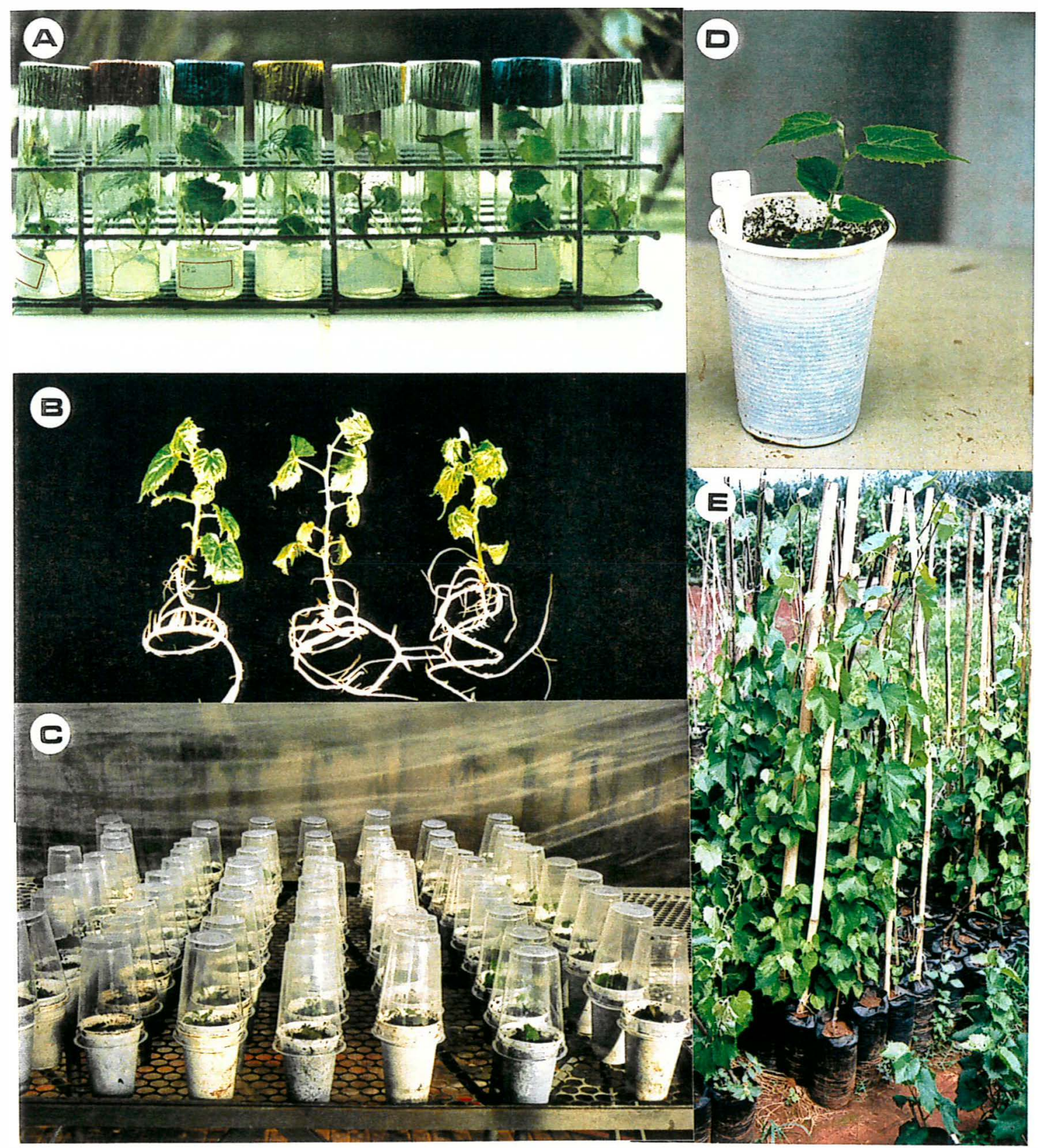

FIGURA 17. Micropropagação do porta-enxerto 'Jales': A-multiplicação in vitro; B-plantas prontas para aclimatização; C-plantas em fase de aclimatização dentro de recipientes fechados em câmara de nebulização; D-planta pronta para plantio em recipientes; E-plantas micropropagadas crescendo ao ar livre. 


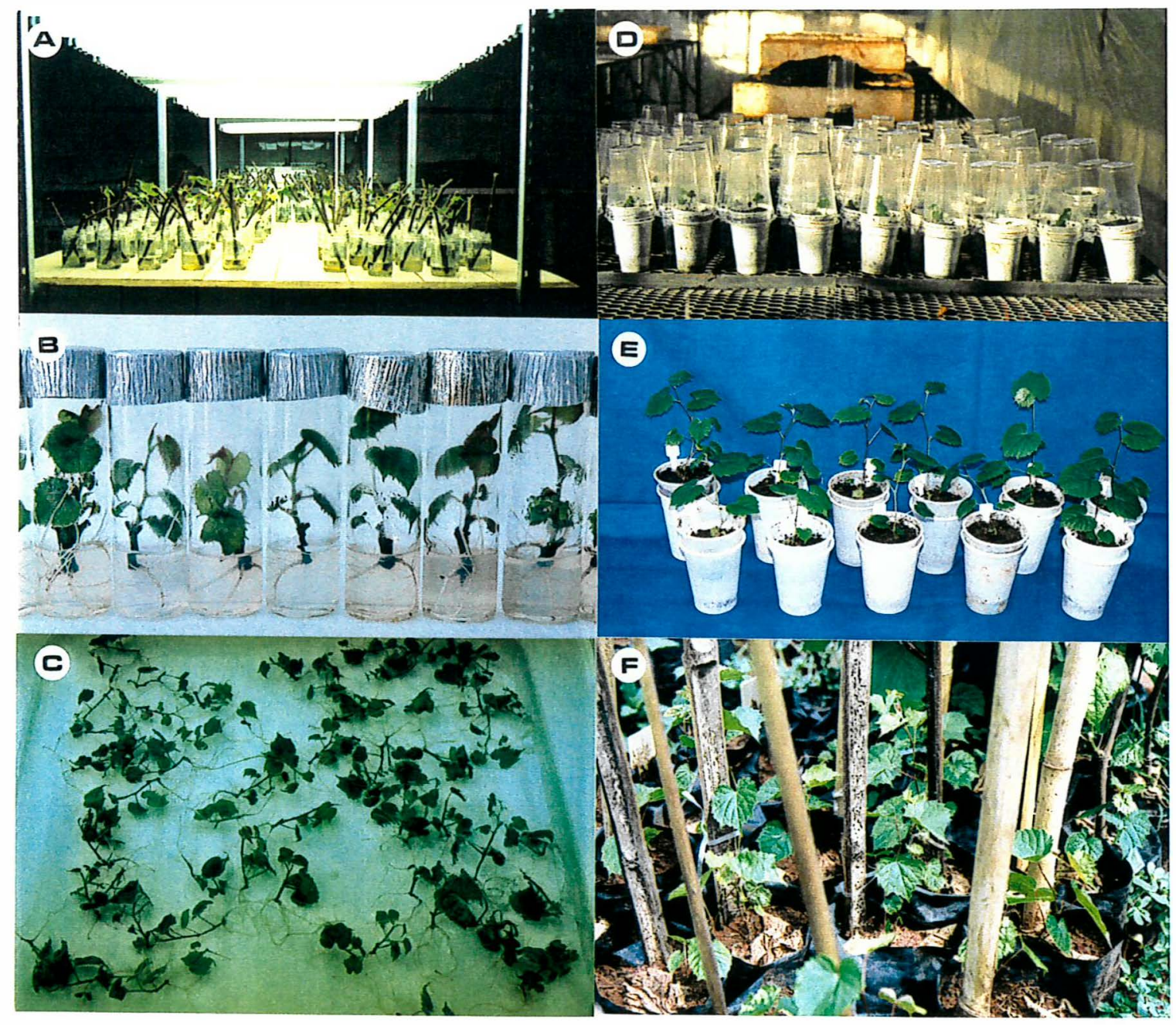

FIGURA 18. Micropropagação do porta-enxerto 'Campinas': A-estacas em brotação para fornecimento de explantes; B-crescimento inicial in vitro; C-plantas recém retiradas dos frascos e prontas para aclimatização; D-plantas em fase de aclimatização dentro de recipientes fechados em câmara de nebulização; E-plantas prontas para plantio em recipientes; F-plantas micropropagadas crescendo ao ar livre. 
TABELA 18. Comprimento da brotação principal, comprimento total das brotações, comprimento médio dos entrenós e número total de gemas por planta dos porta-enxertos 'Jales' e 'Campinas' obtidos por estaquia e micropropagação (Experimento 4.4; apêndice 22).

\begin{tabular}{lcccc}
\hline Tratamentos & $\begin{array}{c}\text { Comprimento da } \\
\text { brotação } \\
\text { principal/planta } \\
(\mathrm{cm})\end{array}$ & $\begin{array}{c}\text { Comprimento } \\
\text { total das } \\
\text { brotações/planta } \\
(\mathrm{cm})\end{array}$ & $\begin{array}{c}\text { Comprimento } \\
\text { médio dos } \\
\text { entrenós } \\
(\mathrm{cm})\end{array}$ & $\begin{array}{c}\text { Número total } \\
\text { de gemas/ } \\
\text { planta }\end{array}$ \\
\hline Jales/Estaca & $95,2 \mathrm{a} 1$ & $319,6 \mathrm{a}$ & $4,9 \mathrm{a}$ & $68,0 \mathrm{a}$ \\
Campinas/Estaca & $93,2 \mathrm{a}$ & $329,0 \mathrm{a}$ & $4,5 \mathrm{a}$ & $71,8 \mathrm{a}$ \\
Jales/Micropr. & $111,3 \mathrm{a}$ & $171,3 \mathrm{~b}$ & $4,7 \mathrm{a}$ & $36,3 \mathrm{~b}$ \\
Campinas/Micropr. & $54,4 \mathrm{~b}$ & $68,7 \mathrm{~b}$ & $3,4 \mathrm{~b}$ & $20,3 \mathrm{~b}$ \\
\hline C.V.(\%) & 15,0 & 23,8 & 10,2 & 22,4 \\
\hline
\end{tabular}

${ }^{1}$ Médias seguidas pela mesma letra não diferem significativamente pelo teste de Tukey ao nivel de $5 \%$ de probabilidade.

TARELA 19. Diâmetro da brotação principal, peso da parte aérea, peso do sistema radicular e volume do sistema radicular por planta dos porta-enxertos 'Jales' e 'Campinas' obtidos por estaquia e micropropagação (Experimento 4.4; apêndice 23).

\begin{tabular}{lcccc}
\hline Tratamentos & $\begin{array}{c}\text { Diâmetro da } \\
\text { brotação } \\
\text { principal } \\
(\mathrm{mm})\end{array}$ & $\begin{array}{c}\text { Peso da parte } \\
\text { aérea/planta } \\
(\mathrm{g})\end{array}$ & $\begin{array}{c}\text { Peso do sistema } \\
\text { radicular/planta }\end{array}$ & $\begin{array}{c}\text { Volume do } \\
\text { sistema } \\
\text { radicular/ } \\
\text { planta (ml) }\end{array}$ \\
\hline Jales/Estaca & $6,6 \mathrm{a} \mathrm{l}$ & $112,8 \mathrm{a}$ & $48,6 \mathrm{a}$ & $40,6 \mathrm{a}$ \\
Campinas/Estaca & $6,0 \mathrm{a}$ & $98,6 \mathrm{a}$ & $34,4 \mathrm{~b}$ & $35,0 \mathrm{a}$ \\
Jales/Micropr. & $4,0 \mathrm{~b}$ & $31,9 \mathrm{~b}$ & $31,5 \mathrm{~b}$ & $28,8 \mathrm{ab}$ \\
Campinas/Micropr. & $2,8 \mathrm{c}$ & $6,3 \mathrm{c}$ & $14,7 \mathrm{c}$ & $11,6 \mathrm{~b}$ \\
\hline C.V.(\%) & 6,7 & 18,3 & 17,1 & 29,3 \\
\hline
\end{tabular}

${ }^{1}$ Médias seguidas pela mesma letra não diferem significativamente pelo teste de Tukey ao nível de $5 \%$ de probabilidade. 
O porta-enxerto 'Jales' demonstrou melhor desenvolvimento do que o 'Campinas' quando micropropagado, apresentando valores superiores a este em todas as variáveis analisadas (Tabelas 18 e 19). Possivelmente o processo de cultivo in vitro ocasionou uma perda de vigor para este porta-enxerto. Talvez o protocolo utilizado para a micropropagação, apesar de satisfatório para o 'Jales', não tenha sido ideal para o 'Campinas'. Provavelmente as diferenças ocorreram devido à composição do meio de cultura, caso os porta-enxertos tenham exigências nutricionais diferentes.

O menor crescimento das plantas micropropagadas deve-se, provavelmente, ao fato de que elas cresceram às custas dos produtos da sua própria fotossíntese, partindo de um tamanho muito pequeno, enquanto as estacas já possuiam uma grande quantidade de nutrientes armazenados, possibilitando um crescimento inicial rápido e vigoroso.

Os porta-enxertos micropropagados não apresentaram crescimento satisfatório para que fosse possível realizar a enxertia lenhosa de inverno, principalmente devido ao pequeno diâmetro da copa (Tabela 19), mas poderiam ser levados para um viveiro ou a campo no lugar das estacas, para realizar a enxertia no próximo ano.

Com o atual sistema de produção de mudas de videira, através da enxertia a campo, as plantas obtidas pela micropropagação dificilmente terão condições de substituir as estacas lenhosas, que apresentam maior vigor, maior facilidade de manuseio e custo mais baixo. Entretanto, as plantas micropropagadas podem ser utilizadas em outros sistemas de produção, como o da enxertia verde utilizado na Europa, onde as mudas são produzidas em larga escala através da enxertia verde com máquina sobre porta-enxertos micropropagados (Anaclerio et al., 1992; 
Boubals, 1987; Martin \& Collas, 1992) ou pela microenxertia in vitro (Hassani, 1990; Hassani \& Boubals, 1991; Martino, 1992). Também deve-se lembrar a importância da cultura de meristemas para a obtenção de plantas matrizes livres de vírus, de onde são retiradas as estacas lenhosas (Krul \& Mowbray, 1984).

Estudos comparativos ampelométricos entre videiras obtidas por estaquia e cultura in vitro foram realizados por Martinez \& Mantilla (1993) e Martinez \& Mantilla (1995) com o cultivar Albariño. Em ambos os trabalhos, após 5 anos a campo, as plantas provenientes da cultura in vitro apresentaram características juvenis, relacionadas com a pubescência, morfologia foliar e pigmentação. Estas também apresentaram-se menos férteis do que as videiras obtidas pela estaquia, não apenas pela menor produção de cachos por planta, mas também devido ao menor tamanho e peso dos cachos. As plantas de cultura in vitro também apresentaram menor tamanho do pedicelo, hilo mais visível, bagas mais achatadas e sementes mais pesadas.

Resultados semelhantes também foram obtidos com o cultivar Corvina Veronese por Cancellier \& Cossio (1988). Estes autores encontraram diferenças na morfologia foliar, pubescência, coloração de folhas e brotos, tamanho de cachos e na fertilidade. Após o sexto ano de plantio algumas destas diferenças desapareceram, como a morfologia foliar e fertilidade, mas outras ainda permaneceram.

O rejuvenescimento provocado pela cultura in vitro também foi relatado por Mullins et al. (1979) para o cultivar Cabernet Sauvignon. Estes autores sugeriram que o controle da expressão de características juvenis ou adultas pode estar relacionado com a distância entre as raízes e o ápice dos brotos. Este controle pode ocorrer através de um gradiente de concentração de hormônios 
endógenos, principalmente giberelinas e citocininas. Devido ao próprio crescimento em extensão das plantas, o ápice torna-se cada vez mais distante das raízes e o nível de giberelinas nos ápices diminue. Na cultura in vitro, os contínuos subcultivos mantêm os ápices dos brotos próximos das raízes. No caso do cultivar Cabernet Sauvignon, após as plantas sofrerem o rejuvenescimento in vitro, foram transferidas para uma casa de vegetação e gradualmente com o seu crescimento as características adultas reapareceram.

O tempo para a perda das características juvenis pode estar relacionado com a espécie, pois Wetzstein \& Myers (1994) comparando videiras muscadíneas (Vitis rotundifolia) do cultivar Summit obtidas por micropropagação e estaquia, apenas verificaram características juvenis nas plantas micropropagadas durante $o$ período de aclimatização em casa de vegetação. Após o plantio a campo, estas características desapareceram. Alguns componentes da produtividade, incluindo o número de flores por brotação e inflorescência, número de frutos e peso dos frutos, foram maiores nas plantas micropropagadas durante o segundo ano, mas no terceiro ano estas diferenças não foram mais verificadas.

\subsection{Comparação do desenvolvimento aéreo e radicular em minirizotron} de plantas obtidas por estaquia lenhosa e micropropagação dos porta- enxertos 'Jales' e 'Campinas'

A análise das videiras em minirizotrons foi realizada para complementar os dados obtidos em recipientes, já que nestas estruturas foi possível acompanhar o desenvolvimento aéreo e radicular dos porta-enxertos sem a necessidade de 
destruição das plantas. Este método foi escolhido baseando-se nos trabalhos de Bohm (1979), Taylor \& Willatt (1981) e Zanette \& Comem (1992).

As observações realizadas em minirizotron confirmaram os resultados obtidos em recipientes. $\mathrm{O}$ desenvolvimento das plantas obtidas de estaca foi maior do que as micropropagadas para ambos os porta-enxertos, observando-se maior área foliar por planta (Figura 19), maior número de raízes por planta (Figura 21) e maior comprimento total de raízes por planta (Figura 22). Apenas quanto ao comprimento total das brotações por planta, as mudas micropropagadas do 'Jales' superaram as provenientes de estaca ao final do experimento (Figura 20).

O crescimento inicial da área foliar foi bastante elevado nas mudas de estaca, quando comparado com as micropropagadas, possivelmente pela maior quantidade de substâncias de reserva presentes nas estacas. Os valores máximos de área foliar foram atingidos na avaliação do dia 11 de março de 1996 (Figura 19), quando passaram a diminuir pela queda das folhas basais mais velhas, revelando o início da entrada no período de dormência.

Apesar da redução na área foliar a partir desta data, ainda se observou um pequeno aumento no comprimento total das brotações (Figura 20) e um aumento considerável no número (Figura 21) e comprimento de raízes por planta (Figura 22). Possivelmente este crescimento ocorreu às custas de substâncias translocadas das folhas antes da abscisão.

A partir da avaliação realizada no dia 13 de maio de 1996, o crescimento das brotações e raízes permaneceu praticamente estável, revelando que as plantas entraram em repouso devido à redução na temperatura ambiental (Apêndice 29). 


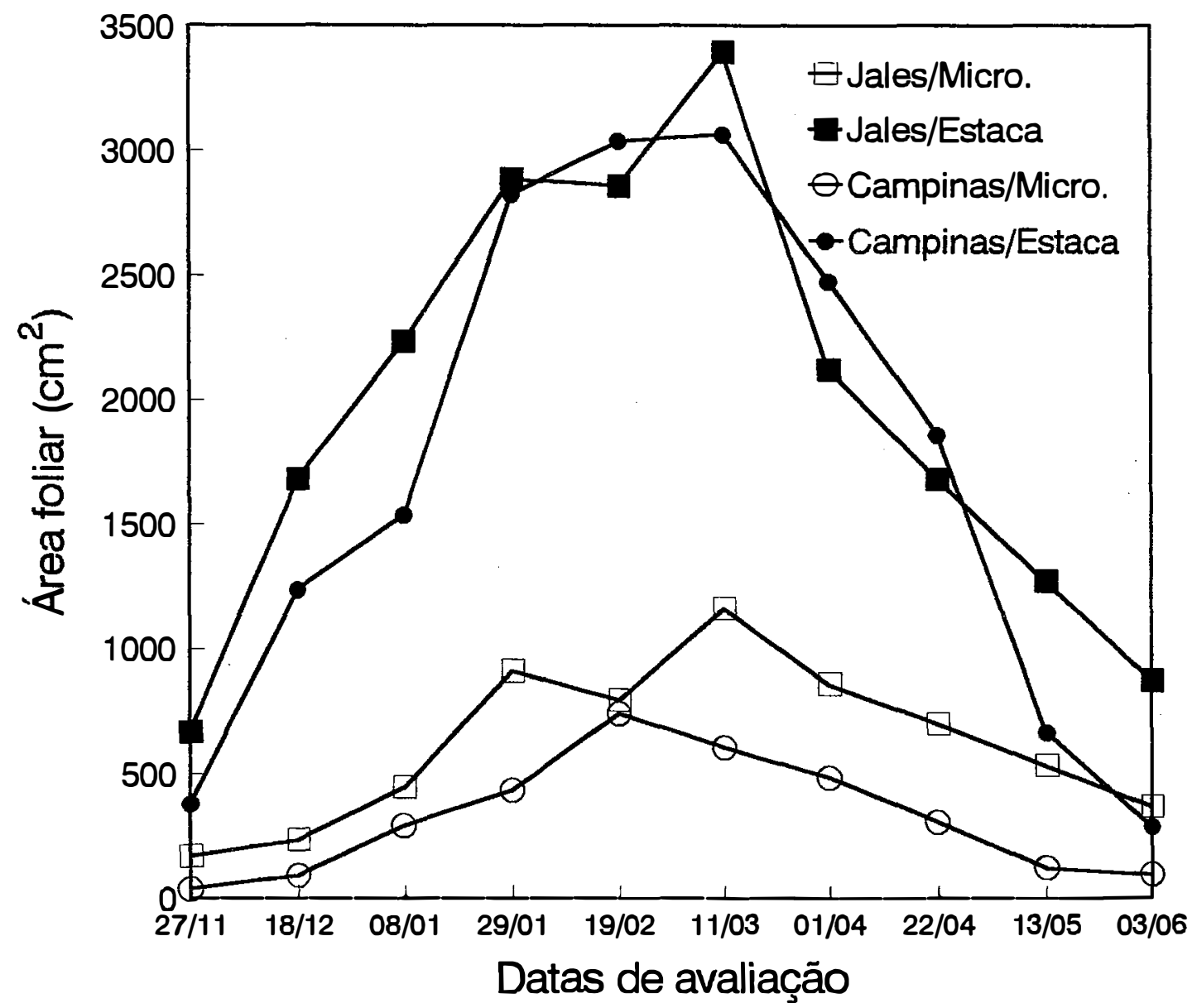

FIGURA 19. Comportamento da área foliar de plantas obtidas de estaca e por micropropagação dos porta-enxertos 'Jales' e 'Campinas' durante o período de 27 de novembro de 1995 a 3 de junho de 1996. Média de três plantas cultivadas em minirizotrons (Experimento 4.5). 


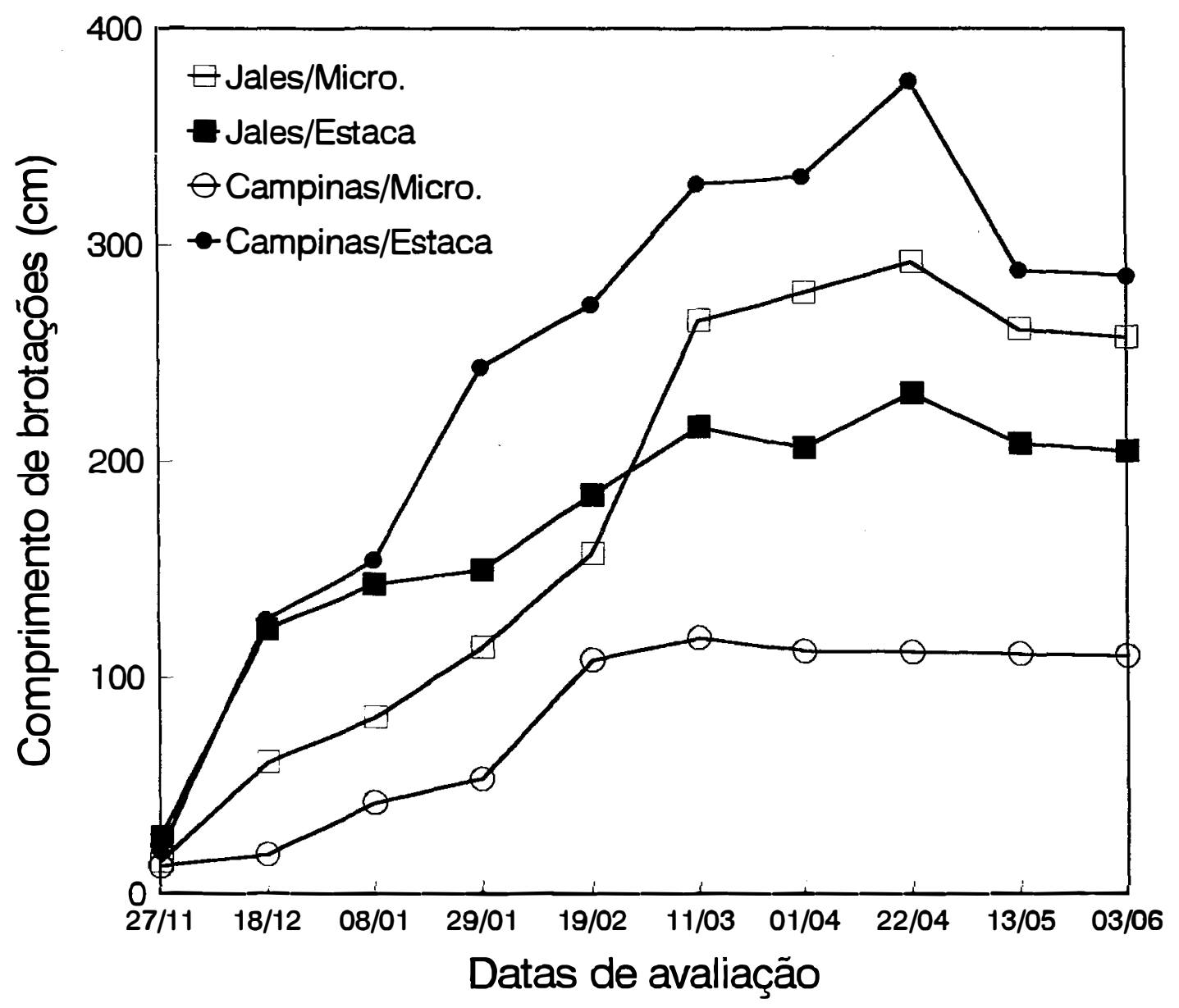

FIGURA 20. Comportamento do comprimento total das brotações de plantas obtidas de estaca e por micropropagação dos porta-enxertos 'Jales' e 'Campinas' durante o período de 27 de novembro de 1995 a 3 de junho de 1996. Média de três plantas cultivadas em mininizotrons (Experimento 4.5). 


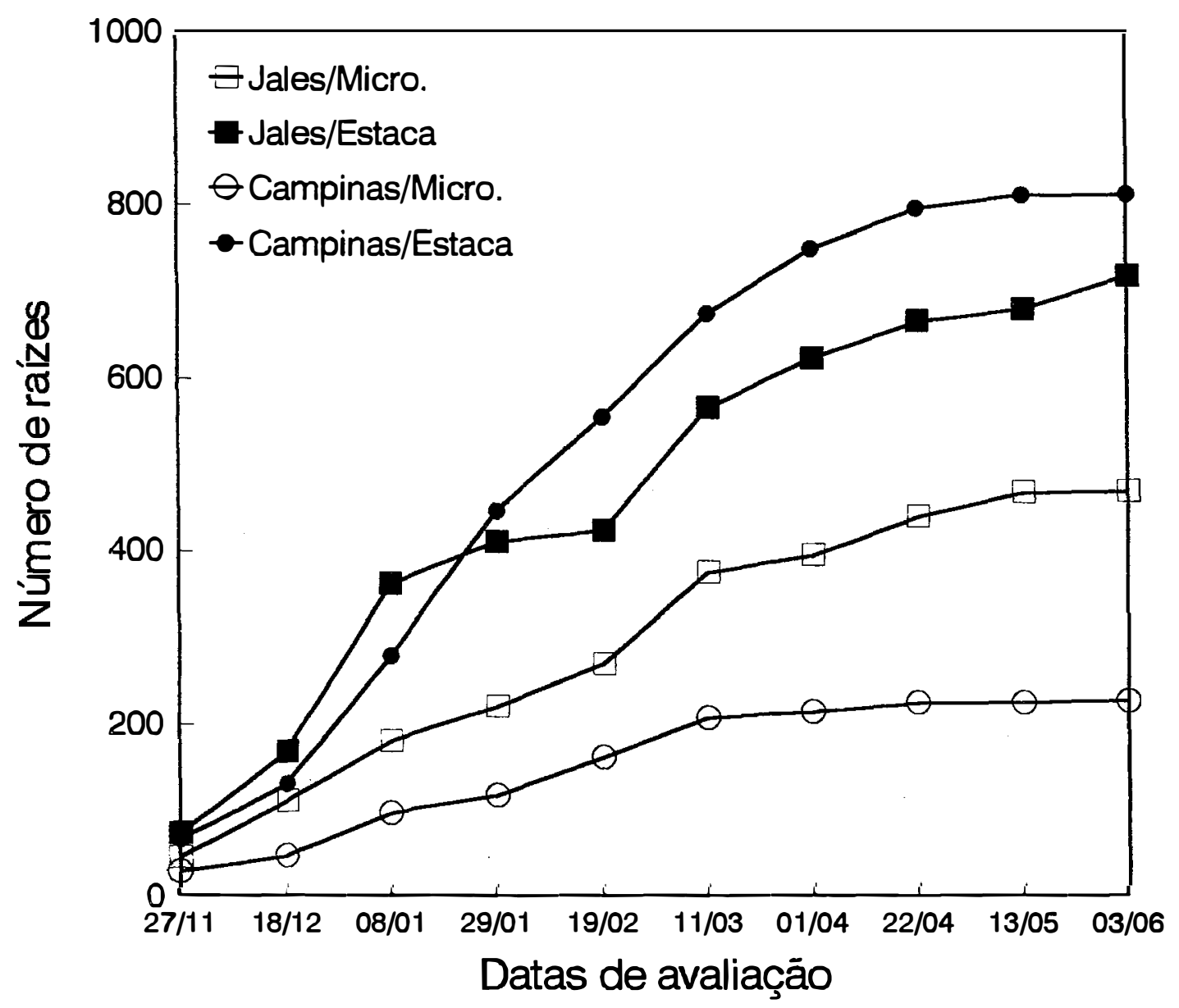

FIGURA 21. Comportamento do número total de raízes de plantas obtidas de estaca e por micropropagação dos porta-enxertos 'Jales' e 'Campinas' durante o período de 27 de novembro de 1995 a 3 de junho de 1996. Média de três plantas cultivadas em minirizotrons (Experimento 4.5). 


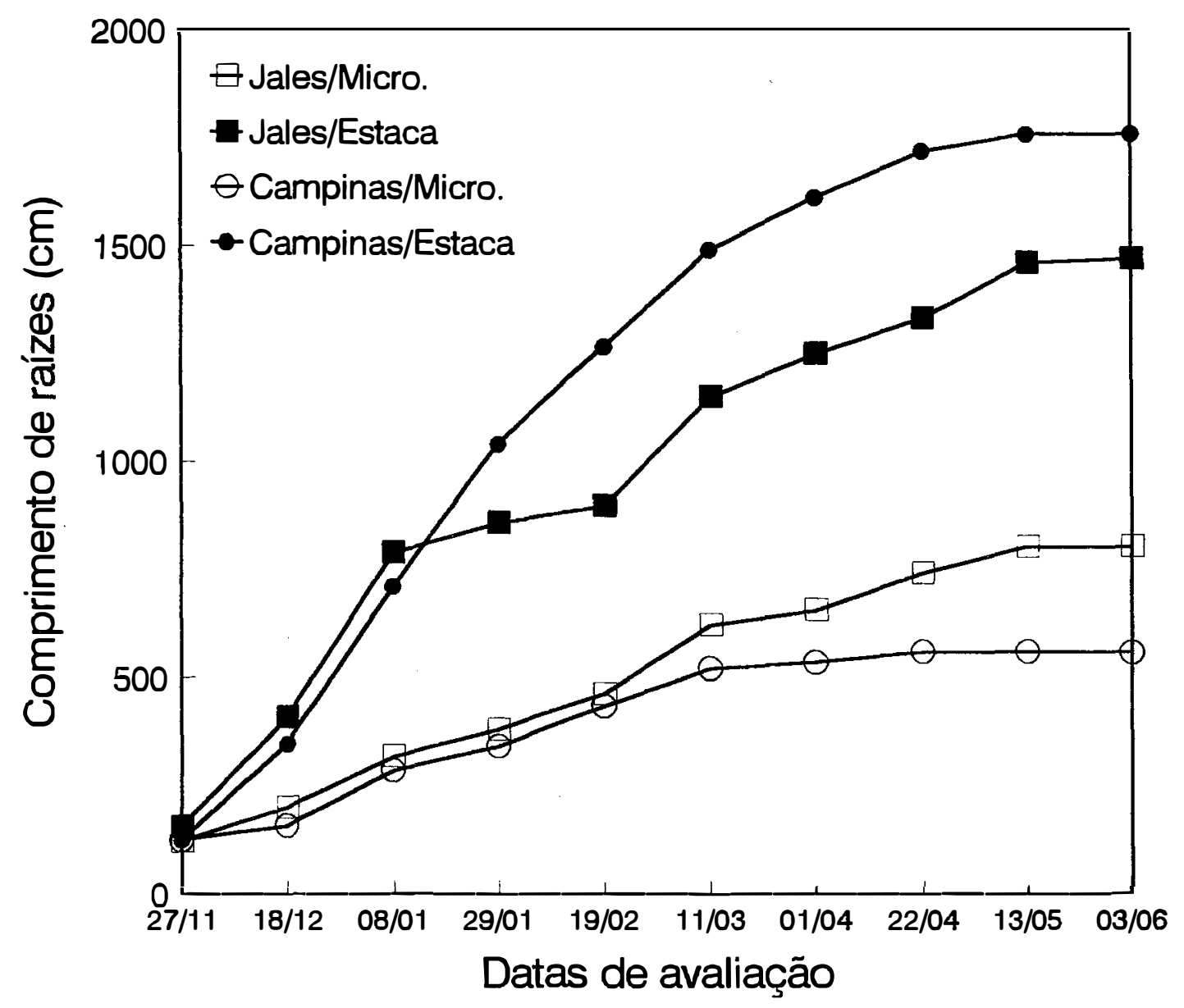

FIGURA 22. Comportamento do comprimento total de raízes de plantas obtidas de estaca e por micropropagação dos porta-enxertos 'Jales' e 'Campinas' durante o período de 27 de novembro de 1995 a 3 de junho de 1996. Média de três plantas cultivadas em minirizotrons (Experimento 4.5). 
O comprimento total das brotações sofreu uma ligeira redução após a avaliação de 22 de abril de 1996, devido ao secamento e queda das pequenas brotações laterais juntamente com as folhas, fato normal na entrada da dormência.

A evolução da distribuição das raízes em profundidade apresentou-se diferenciada entre as plantas obtidas por estaquia e por micropropagação.

As raízes das plantas micropropagadas atingiram profundidades maiores do que as provenientes de estaca nas primeiras avaliações (Figuras 23 e 24), demonstrando um crescimento inicial mais pivotante. $\mathrm{O}$ 'Campinas' na primeira avaliação (90 dias após o plantio) já atingiu a camada de 80 a $100 \mathrm{~cm}$. Já as raízes das plantas provenientes de estaca no início desenvolveram-se mais superficialmente, atingindo a camada de 80 a $100 \mathrm{~cm}$ apenas na quarta avaliação (153 dias após a estaquia) para o 'Campinas' e quinta (174 dias após a estaquia) para o 'Jales'.

Posteriormente à quinta avaliação, o comportamento entre todos os tratamentos foi muito semelhante para a porcentagem do número (Figura 23) e do comprimento de raízes (Figura 24), ocorrendo uma concentração maior de raízes na camada de 0 a $40 \mathrm{~cm}$ de profundidade, com cerca de $70 \%$ do número e $60 \%$ do comprimento de raízes por planta. Estes resultados estão muito próximos dos obtidos por Pire (1985) com o cultivar Alphonse Lavallée enxertado sobre 'Criolla Negra'. O autor analisou a campo plantas com 5 anos de idade e encontrou a maior concentração de raízes em profundidades menores do que $45 \mathrm{~cm}$.

Hidalgo \& Candela (1969), analisando a distribuição do sistema radicular de um vinhedo de 17 anos, formado pelo cultivar Tempranillo enxertado sobre '99 Richter', observaram que a maior densidade radicular ocorreu na camada de 25 a $50 \mathrm{~cm}$ de profundidade. 


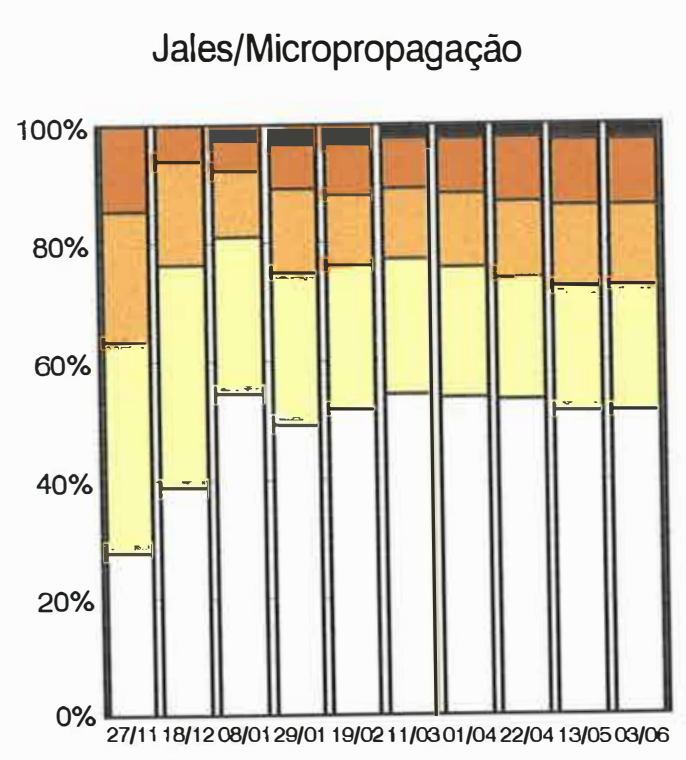

Campinas/Micropropagação

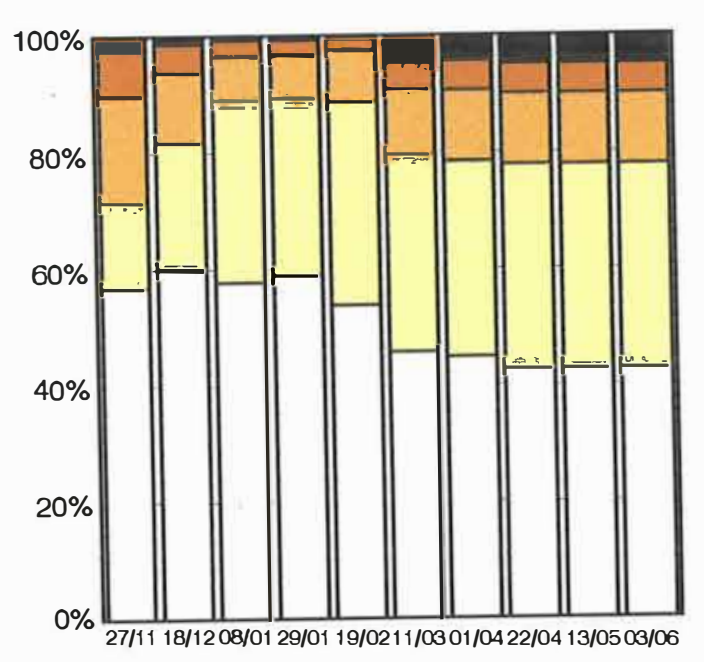

Jales/Estaquia

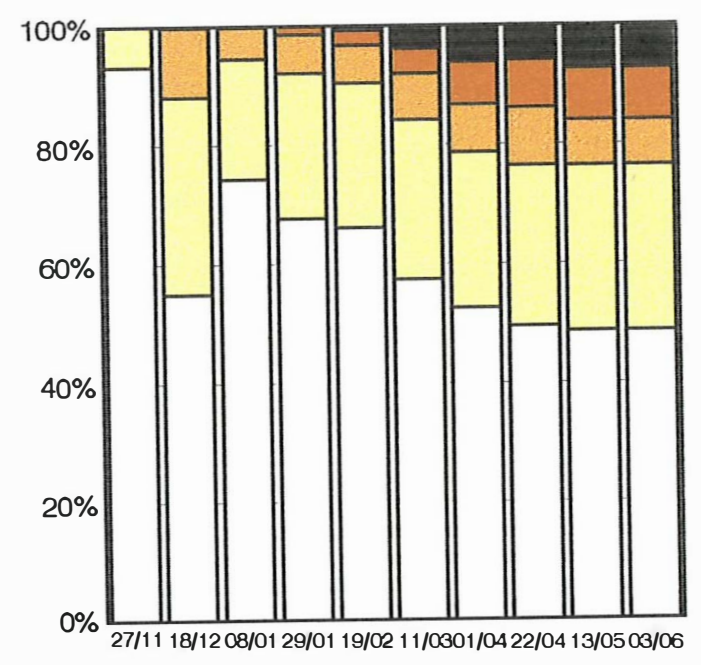

Campinas/Estaquia

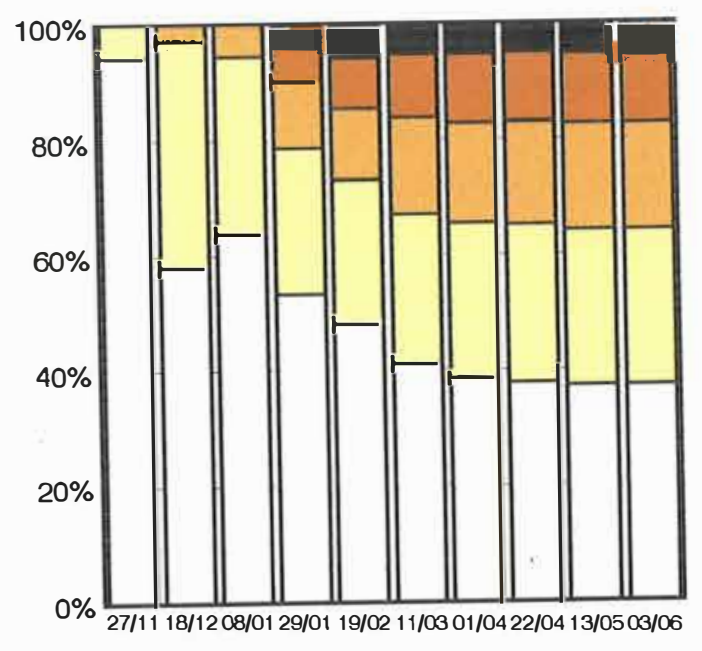

$\underline{\square 0-20 \square 20-40 \square 40-60 \square 60-80 \square 80-100}$

FIGURA 23. Comportamento da porcentagem do número de raízes de plantas obtidas de estaca e por micropropagação dos porta-enxertos 'Jales' e 'Campinas' em cinco profundidades $(\mathrm{cm})$ durante o período de 27 de novembro de 1995 a 3 de junho de 1996. Média de três plantas cultivadas em minirizotrons (Experimento 4.5). 
Jales/Micropropagação

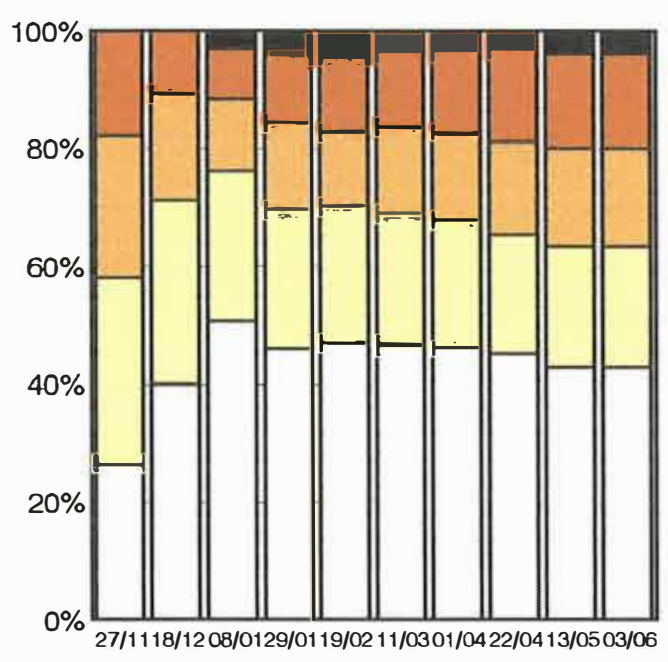

Campinas/Micropropagação

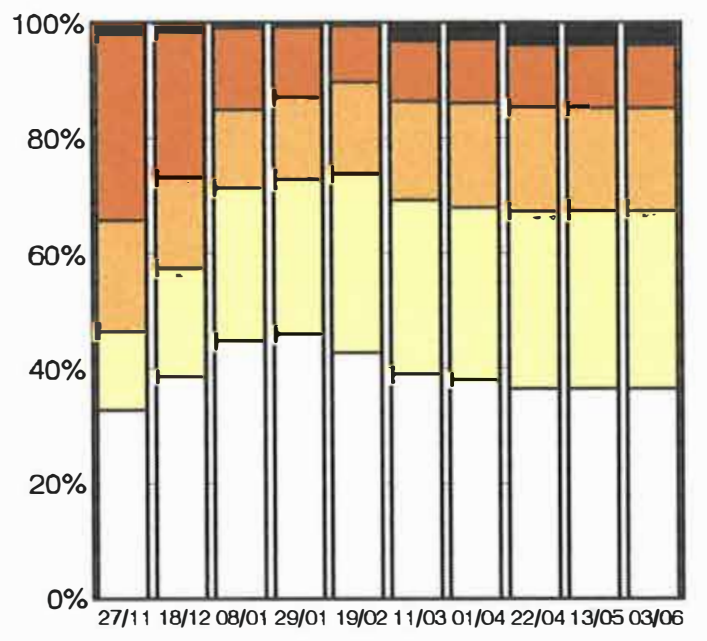

Jales/Estaquia

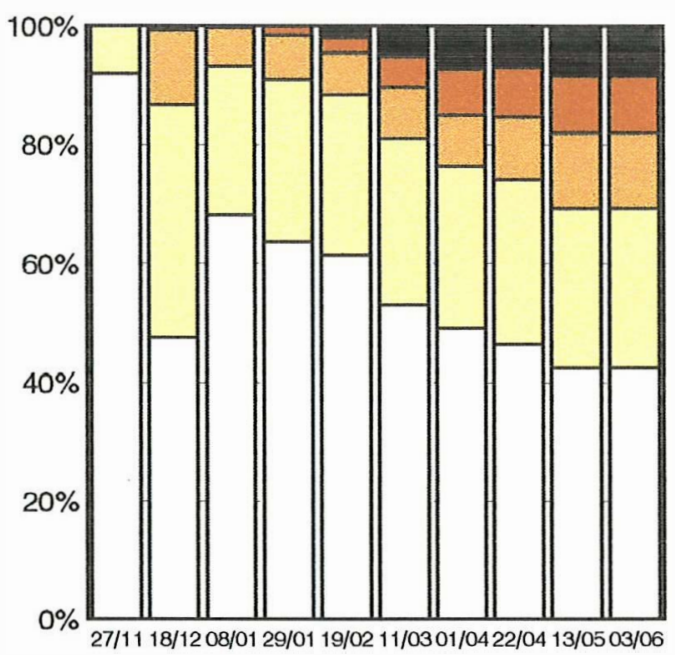

Campinas/Estaquia

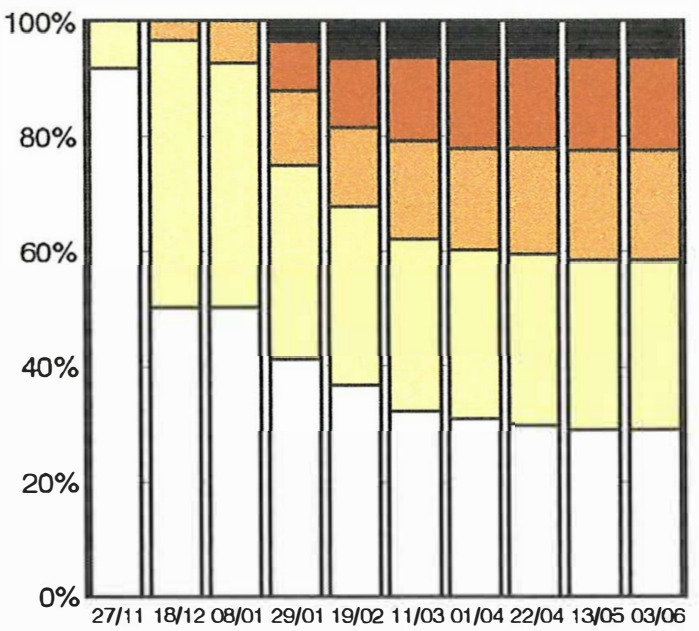

\section{$\square 0-20 \square 20-40 \square 40-60 \square 60-80 \square 80-100$}

FIGURA 24. Comportamento da porcentagem do comprimento de raízes de plantas obtidas de estaca e por micropropagação dos porta-enxertos 'Jales' e 'Campinas' em cinco profundidades $(\mathrm{cm})$ durante o período de 27 de novembro de 1995 a 3 de junho de 1996. Média de três plantas cultivadas em minirizotrons (Experimento 4.5). 
Resultados também semelhantes foram obtidos por Bernabe \& Monreal (1982) que realizaram escavações em diversos vinhedos com idade de 7 a 52 anos do cultivar Palomino enxertado sobre os porta-enxertos '41 B', '196-17', '161-49' e '420-A'. Os autores encontraram a maior quantidade de raízes na profundidade de 50 a $60 \mathrm{~cm}$.

O número médio de raízes em cada profundidade no final do experimento pode ser observado na Figura 25 e o comprimento médio na Figura 26. O número e o comprimento médio de raízes tendeu a diminuir da camada mais superficial para a mais profunda, tanto nas mudas de estaca como nas micropropagadas de forma proporcional.

\subsection{Avaliação do desenvolvimento inicial a campo de mudas do cultivar Itália produzidas por diferentes métodos de enxertia sobre os porta-enxertos 'Jales' e 'Campinas'}

A análise de variância das falhas na estaquia a campo não foi significativa para os porta-enxertos (Apêndice 24).

A perda de plantas com a estaquia direta a campo foi elevada para ambos os porta-enxertos, sendo um pouco menor para o 'Campinas', mas sem diferir significativamente do 'Jales' (Tabela 20). Estas perdas possivelmente ocorreram devido ao grande período de seca verificado após a estaquia (Apêndice 29), sendo insuficientes as irrigações realizadas. Já as estacas mantidas em recipientes, para a reposição das falhas, apresentaram pegamento superior a $90 \%$, sendo que com estas plantas foi realizado o replantio, quando iniciaram as chuvas em novembro, completando todas as parcelas do experimento. 
Jales/Micropropagação

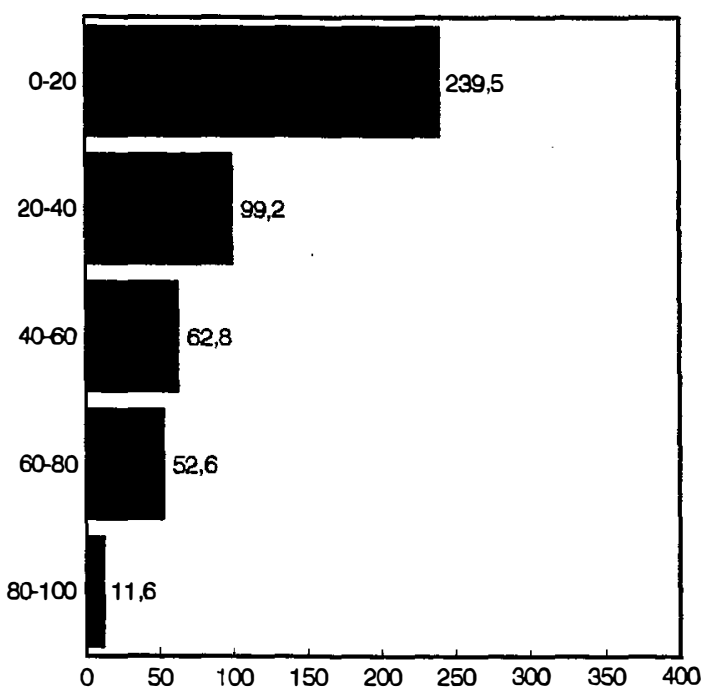

Campinas/Micropropagação

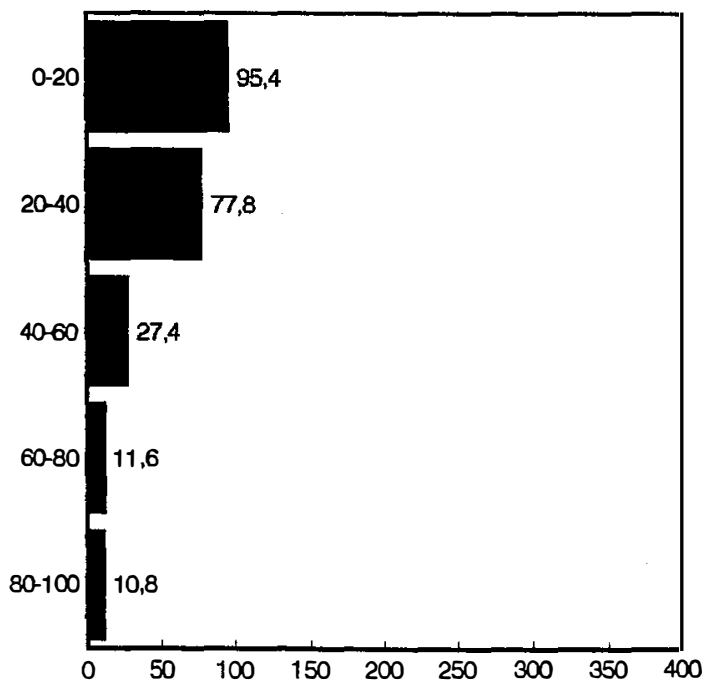

Jales/Estaquia

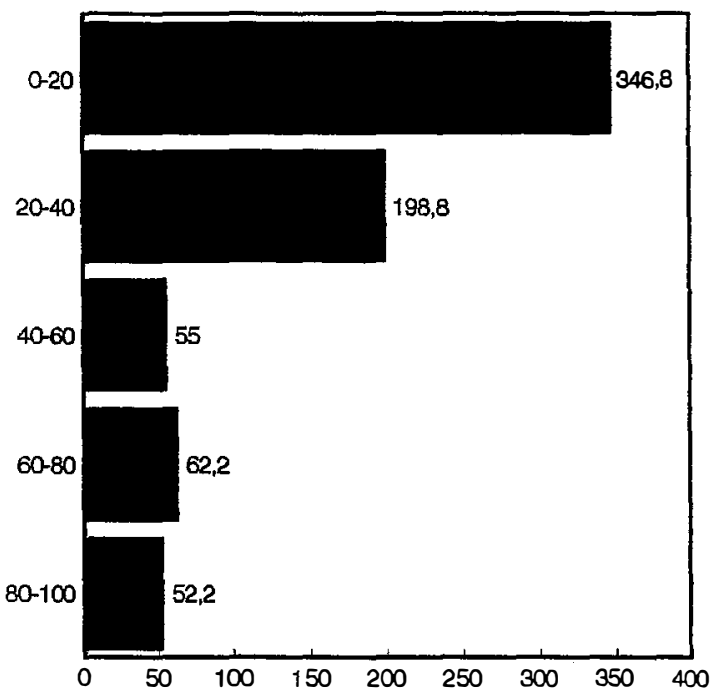

Campinas/Estaquia

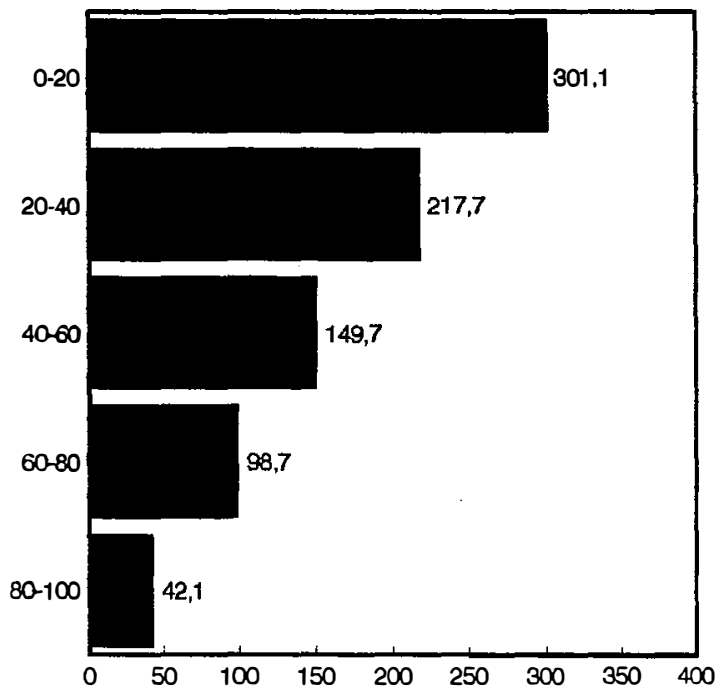

FIGURA 25. Número médio de raízes de plantas obtidas de estaca e por micropropagação dos porta-enxertos 'Jales' e 'Campinas' em cinco profundidades $(\mathrm{cm})$. Média de três plantas cultivadas em minirizotrons (Experimento 4.5). 
Jales/Micropropagação

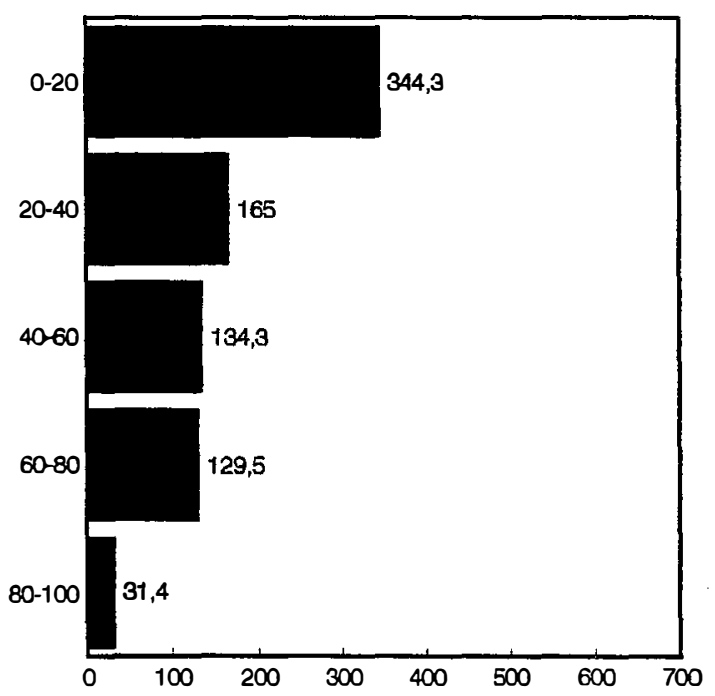

Campinas/Micropropagação

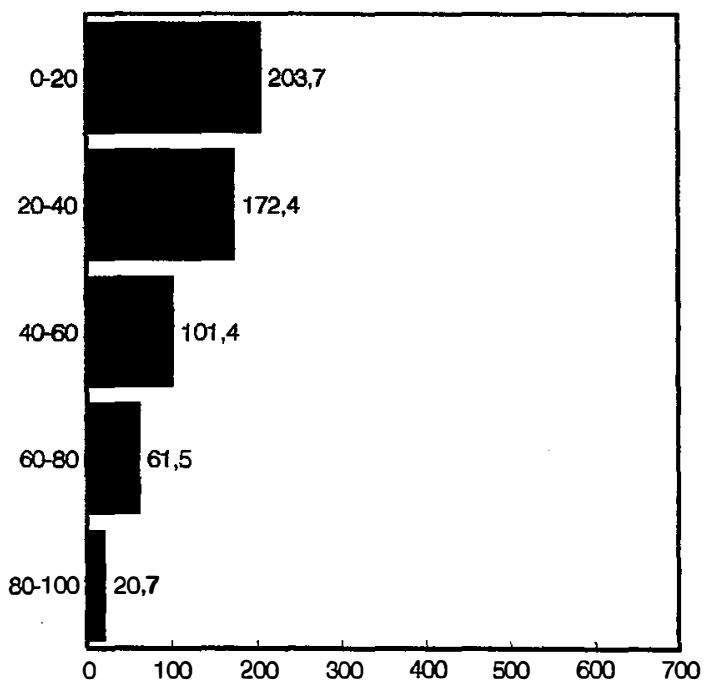

Jales/Estaquia

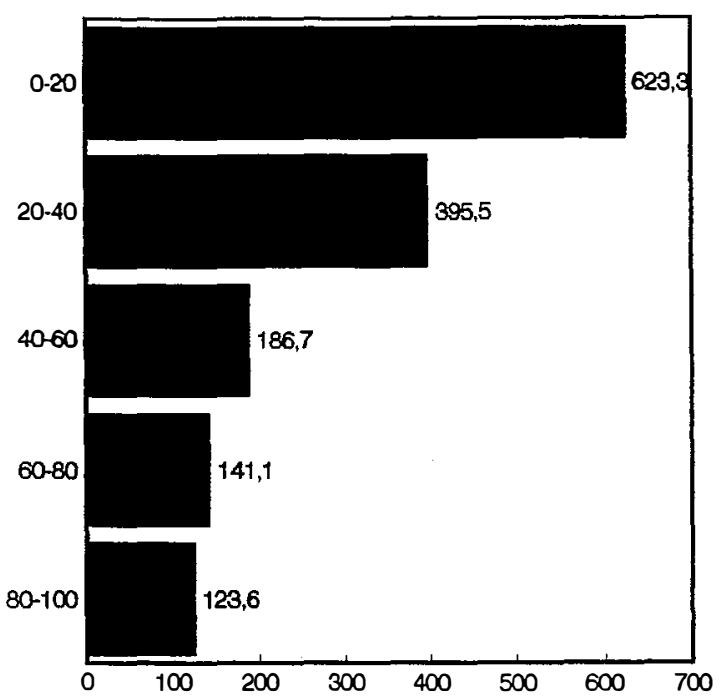

Campinas/Estaquia

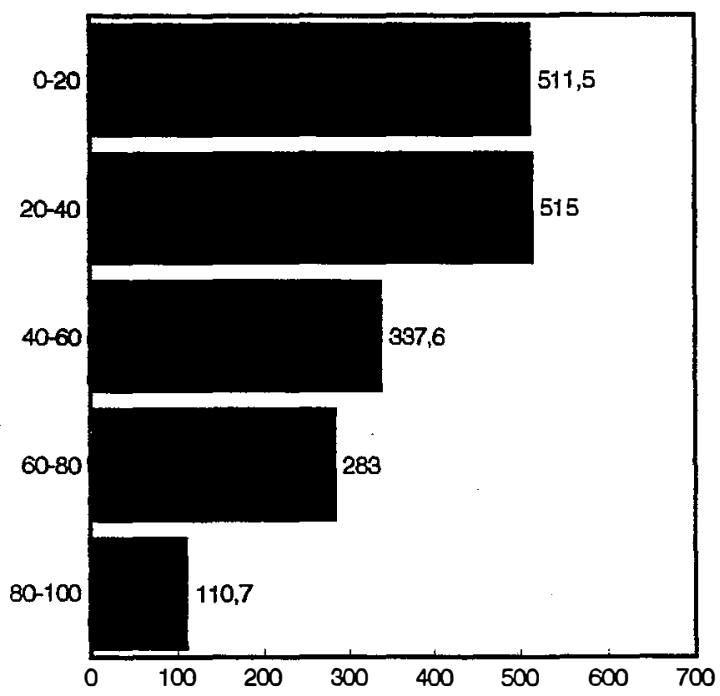

FIGURA 26. Comprimento médio de raízes de plantas obtidas de estaca e por micropropagação dos porta-enxertos 'Jales' e 'Campinas' em cinco profundidades $(\mathrm{cm})$. Média de três plantas cultivadas em mininizotrons (Experimento 4.5). 
TABELA 2.0. Porcentagem de falha na estaquia direta a campo dos porta-enxertos 'Jales' e 'Campinas', quatro meses após o plantio (11/11/94) (Experimento 4.6; apêndice 24).

\begin{tabular}{lc}
\hline Tratamentos & Falhal $(\%)$ \\
\hline Jales/Enxertia na estaca & $72 \mathrm{a}^{2}$ \\
Jales/Enxertia na brotação & $66 \mathrm{a}$ \\
Campinas/Enxertia na estaca & $58 \mathrm{a}$ \\
Campinas/Enxertia na brotação & $36 \mathrm{a}$ \\
\hline C.V.(\%) & 44,5 \\
\hline
\end{tabular}

${ }^{1}$ Dados transformados em arc sen $(\mathrm{X} / 100)^{1 / 2}$

2Médias seguidas pela mesma letra não diferem significativamente pelo teste de Tukey a $5 \%$ de probabilidade.

Um ano após a estaquia a campo, antes de realizar a enxertia, o desenvolvimento dos porta-enxertos foi avaliado (Apêndice 25), verificando-se uma boa uniformidade entre as parcelas de um mesmo porta-enxerto e também um maior crescimento do 'Jales' que foi significativamente superior ao 'Campinas' quanto ao diâmetro da estaca e da brotação. $O$ peso das brotações também foi superior para o 'Jales', mas sem diferir significativamente. Quanto ao número de brotações por estaca não houve diferença entre os porta-enxertos, permanecendo próximo de 1,7 brotos por planta (Tabela 21 ).

$\mathrm{Na}$ mesma época também foram avaliadas a campo as mudas obtidas pela enxertia de mesa (Apêndice 26), observando-se uma grande mortalidade que atingiu 56,1\% para o 'Campinas' e 26,4\% para o 'Jales'. Além da menor perda, o 'Jales' também apresentou maior diâmetro da estaca, mas não diferiu do 'Campinas' quanto ao diâmetro da copa (Tabela 22). Ribas \& Fraga Junior (1960) também observaram um alto índice de falhas $(42,5 \%)$ com o plantio de mudas enxertadas do cultivar Niagara Rosada sobre o porta-enxerto 'RR 101-14'. 
TABELA 21. Avaliação do desenvolvimento dos porta-enxertos 'Jales' e 'Campinas' antes da enxertia (11/07/95) (Experimento 4.6; apêndice 25).

\begin{tabular}{lcccc}
\hline Tratamentos & $\begin{array}{c}\text { Diâmetro da } \\
\text { estaca } \\
(\mathrm{mm})\end{array}$ & $\begin{array}{c}\text { Diâmetro da } \\
\text { brotação } \\
(\mathrm{mm})\end{array}$ & $\begin{array}{c}\text { Número de } \\
\text { brotações/ } \\
\text { estaca }\end{array}$ & $\begin{array}{c}\text { Peso das } \\
\text { brotações/ } \\
\text { plantal }(\mathrm{g})\end{array}$ \\
\hline $\begin{array}{l}\text { Jales/Enxertia na } \\
\text { brotação } \\
\text { Jales/Enxertia na }\end{array}$ & $12,5 \mathrm{a}^{2}$ & $7,5 \mathrm{a}$ & $1,7 \mathrm{a}$ & $54,0 \mathrm{a}$ \\
$\begin{array}{l}\text { estaca } \\
\text { Campinas/Enxertia }\end{array}$ & $8,8 \mathrm{~b}$ & $5,7 \mathrm{c}$ & $1,8 \mathrm{a}$ & $26,4 \mathrm{a}$ \\
$\begin{array}{l}\text { na brotação } \\
\text { Campinas/Enxertia } \\
\text { na estaca }\end{array}$ & $8,8 \mathrm{~b}$ & $5,9 \mathrm{bc}$ & $1,8 \mathrm{a}$ & $27,3 \mathrm{a}$ \\
\hline C.V.(\%) & 9,8 & 10,7 & $13,5 \mathrm{a}$ & 20,7 \\
\hline
\end{tabular}

lDados transformados em $\mathrm{X}^{1 / 2}$

${ }^{2}$ Médias seguidas pela mesma letra não diferem significativamente pelo teste de Tukey a $5 \%$ de probabilidade.

TABELA 22. Avaliação do desenvolvimento das mudas obtidas pela enxertia de mesa sete meses após o plantio a campo (15/07/95) (Experimento 4.6; apêndice 26).

\begin{tabular}{lccc}
\hline Tratamentos & $\begin{array}{c}\text { Mortalidade } \\
(\%)\end{array}$ & $\begin{array}{c}\text { Diâmetro da } \\
\text { estaca }(\mathrm{mm})\end{array}$ & $\begin{array}{c}\text { Diâmetro da copa } \\
(\mathrm{mm})\end{array}$ \\
\hline Jales/Itália & $26,4 \mathrm{~b}^{\mathrm{l}}$ & $10,1 \mathrm{a}$ & $5,5 \mathrm{a}$ \\
Campinas/Itália & $56,1 \mathrm{a}$ & $8,1 \mathrm{~b}$ & $5,1 \mathrm{a}$ \\
\hline C.V.(\%) & 20,3 & 4,5 & 6,8 \\
\hline lMédias seguidas pela mesma letra não diferem significativamente pelo teste de \\
Tukey a 5\% de probabilidade.
\end{tabular}


As avaliações mensais do comprimento da brotação da copa apresentaram interação significativa entre os tipos de enxertia e os porta-enxertos em todas as datas avaliadas (Apêndice 27).

O comportamento do crescimento da brotação da copa foi muito semelhante em todas as datas de avaliação. De maneira geral, para o 'Jales' a enxertia a campo na estaca e na brotação não diferiram significativamente e foram superiores à enxertia de mesa. Esta tendência também foi observada para 0 'Campinas', mas em quase todas as avaliações os tipos de enxertia não diferiram significativamente (Tabela 23).

O plantio de mudas enxertadas do cultivar Niagara Rosada também resultou em plantas com menor vigor e menos produtivas do que as enxertadas a campo, no experimento realizado por Ribas \& Fraga Junior (1960). Sousa (1996) também relatou que no Estado de São Paulo, a enxertia de mesa não apresenta bons resultados, recomendando como único processo viável o da enxertia a campo, também recomendada por Terra et al. (1993) para o cultivar Itália.

Quando comparam-se os porta-enxertos dentro de cada tipo de enxertia, observa-se em todas as avaliações que o 'Jales' foi superior ao 'Campinas' na enxertia realizada a campo, tanto na brotação como na estaca, mas não diferiu do 'Campinas' na enxertia de mesa (Tabela 23). Terra et al. (1988a) também observaram que o 'Jales' induziu maior produção por planta no cultivar Niagara Rosada do que o 'Campinas', porém sem diferir significativamente. De forma geral, estes porta-enxertos apresentam boa afinidade e conferem elevada produtividade em diversos cultivares para vinho ou de mesa no Estado de São Paulo (Martins et al., 1981; Terra et al., 1990a; Terra et al., 1990b). 
TABELA 23. Comprimento da brotação da copa do cultivar Itália enxertado sobre 'Jales' e 'Campinas' em diversas datas de avaliação (Experimento 4.6; apêndice 27).

\begin{tabular}{|c|c|c|c|c|}
\hline \multirow[t]{2}{*}{ Avaliação } & \multirow{2}{*}{$\begin{array}{l}\text { Tipo de } \\
\text { enxertia }\end{array}$} & \multicolumn{2}{|c|}{ Porta-enxerto } & \multirow[t]{2}{*}{ C.V.(\%) } \\
\hline & & Jales & Campinas & \\
\hline \multirow{3}{*}{$08 / 11 / 95$} & Brotação & $87,6 \mathrm{Aa}^{1}$ & $47,1 \mathrm{Ba}$ & \multirow{3}{*}{22,3} \\
\hline & Estaca & $89,8 \mathrm{Aa}$ & $50,7 \mathrm{Ba}$ & \\
\hline & Mesa & $42,1 \mathrm{Ab}$ & $35,3 \mathrm{Aa}$ & \\
\hline \multirow{3}{*}{ 07/12/95 } & Brotação & $125,2 \mathrm{Aa}$ & $59,8 \mathrm{Ba}$ & \multirow{3}{*}{22,1} \\
\hline & Estaca & $114,8 \mathrm{Aa}$ & $49,7 \mathrm{Ba}$ & \\
\hline & Mesa & $47,4 \mathrm{Ab}$ & $37,9 \mathrm{Aa}$ & \\
\hline \multirow{3}{*}{ 09/01/96 } & Brotação & $162,8 \mathrm{Aa}$ & $76,4 \mathrm{Ba}$ & \multirow{3}{*}{20,6} \\
\hline & Estaca & $135,7 \mathrm{Aa}$ & $59,9 \mathrm{Ba}$ & \\
\hline & Mesa & $65,5 \mathrm{Ab}$ & 48,9Aa & \\
\hline \multirow{3}{*}{$08 / 02 / 96$} & Brotação & $165,0 \mathrm{Aa}$ & $83,1 \mathrm{Ba}$ & \multirow{3}{*}{19,1} \\
\hline & Estaca & $147,9 \mathrm{Aa}$ & $64,1 \mathrm{Ba}$ & \\
\hline & Mesa & $73,7 \mathrm{Ab}$ & $57,4 \mathrm{Aa}$ & \\
\hline \multirow{3}{*}{ 08/03/96 } & Brotação & $177,6 \mathrm{Aa}$ & $99,3 \mathrm{Ba}$ & \multirow{3}{*}{18,1} \\
\hline & Estaca & $168,3 \mathrm{Aa}$ & $74,6 \mathrm{Bab}$ & \\
\hline & Mesa & $84,2 \mathrm{Ab}$ & $57,9 \mathrm{Ab}$ & \\
\hline \multirow{3}{*}{ 09/04/96 } & Brotação & $183,8 \mathrm{Aa}$ & $94,7 \mathrm{Ba}$ & \multirow{3}{*}{19,6} \\
\hline & Estaca & $178,4 \mathrm{Aa}$ & 77,7Bab & \\
\hline & Mesa & $82,1 \mathrm{Ab}$ & $55,7 \mathrm{Ab}$ & \\
\hline \multirow{3}{*}{$09 / 05 / 96$} & Brotação & $175,6 \mathrm{Aa}$ & $88,3 \mathrm{Ba}$ & \multirow{3}{*}{22,3} \\
\hline & Estaca & $177,6 \mathrm{Aa}$ & $85,9 \mathrm{Ba}$ & \\
\hline & Mesa & $83,3 \mathrm{Ab}$ & $58,7 \mathrm{Aa}$ & \\
\hline
\end{tabular}

${ }^{1}$ Médias seguidas pela mesma letra maiúscula na linha e minúscula na coluna não diferem significativamente pelo teste de Tukey a $5 \%$ de probabilidade. 
A superioridade das mudas de 'Itália' enxertadas a campo sobre o portaenxerto 'Jales' pode ser observada na Figura 27, que representa o crescimento da copa das mudas durante o período de avaliação do experimento.

Diversos fatores podem estar associados ao menor desenvolvimento das mudas obtidas pela enxertia de mesa. Talvez o crescimento inicial destas mudas em recipientes tenha causado uma restrição do desenvolvimento do sistema radicular e o fato de serem levadas a campo durante o período chuvoso pode ter favorecido o crescimento das raízes mais superficialmente, deixando as plantas mais suscetíveis ao estresse hídrico durante os períodos de seca. Já na enxertia a campo, os porta-enxertos possuem maiores condições de aprofundar o seu sistema radicular, pois a estaquia é realizada durante o período de seca, obrigando as raízes aprofundarem-se em busca da água, além das plantas crescerem durante um ano com a sua própria copa vigorosa e resistente a doenças.

Quanto ao peso da copa e diâmetro da brotação também houve interação entre os fatores estudados (Apêndice 28).

Para o 'Jales', a enxertia a campo na estaca do porta-enxerto foi superior aos demais tipos de enxertia quanto ao peso da copa, mas quanto ao diâmetro da brotação não houve diferença entre as enxertias realizadas a campo, que foram superiores a enxertia de mesa (Tabela 24).

Para o 'Campinas', as copas mais pesadas e com maior diâmetro também foram as obtidas pela enxertia a campo na estaca, que não diferiu da enxertia a campo na brotação, mas foi superior a enxertia de mesa, para ambas as variáveis (Tabela 24). 


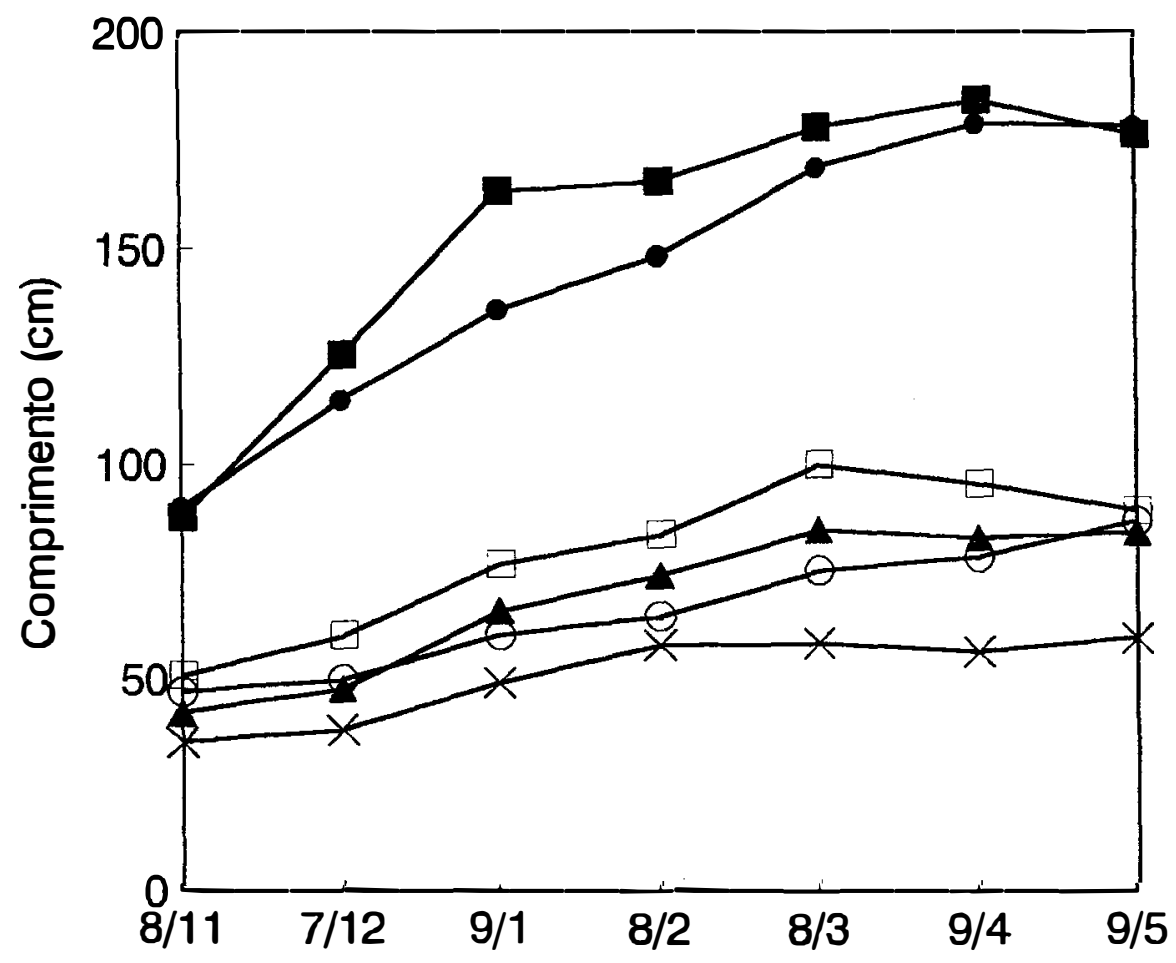

Datas de avaliação

\begin{tabular}{lll}
- -Jales/Brotação & $\bullet$ Jales/Estaca & ^Jales/Mesa \\
$\exists$ Campinas/Brotação & $\ominus$ Campinas/Estaca & $*$ Campinas/Mesa \\
\hline
\end{tabular}

FIGURA 27. Comprimento da brotação de mudas de 'Itália' obtidas por diferentes tipos de enxertia sobre os porta-enxertos 'Jales' e 'Campinas' durante o período de 08/11/95 a 09/05/96 (Experimento 4.6). 
TABELA 24. Peso da copa e diâmetro da brotação do cultivar Itália de mudas dos porta-enxertos 'Jales' e 'Campinas' enxertadas com diferentes tipos de enxertia (Experimento 4.6; apêndice 28).

\begin{tabular}{lcccc}
\hline Variável & Tipo de & \multicolumn{2}{c}{ Porta-enxerto } & \multirow{2}{*}{ C.V.(\%) } \\
\cline { 3 - 4 } & enxertia & Jales & Campinas & \\
\hline Peso da & Estaca & $86,1 \mathrm{Aa}^{1}$ & $40,0 \mathrm{Ba}$ & \\
copa $(\mathrm{g})$ & Brotação & $71,2 \mathrm{Ab}$ & $34,4 \mathrm{Bab}$ & \multirow{2}{*}{16,2} \\
& Mesa & $26,6 \mathrm{Ac}$ & $27,5 \mathrm{Ab}$ & \\
\hline Diâmetro da & Estaca & $9,9 \mathrm{Aa}$ & $8,3 \mathrm{Ba}$ & \\
brotação $(\mathrm{mm})$ & Brotação & $9,2 \mathrm{Aa}$ & $7,8 \mathrm{Bab}$ & 5,9 \\
& Mesa & $7,3 \mathrm{Ab}$ & $7,1 \mathrm{Ab}$ & \\
\hline
\end{tabular}

${ }^{1}$ Médias seguidas pela mesma letra maiúscula na linha e minúscula na coluna não diferem significativamente pelo teste de Tukey a $5 \%$ de probabilidade.

Apesar das formas de enxertia a campo praticamente não diferirem quanto ao crescimento da copa (Tabelas 23 e 24), alguns aspectos fitotécnicos também devem ser levados em consideração para a escolha do tipo de enxertia. A execução da enxertia nas brotações é mais cômoda para o enxertador por ser realizada mais alta do que a enxertia na estaca. O diâmetro das brotações assemelha-se mais com o diâmetro do enxerto, permitindo melhor encaixe do garfo, além de não serem tão lignificadas como a estaca, facilitando os cortes. Pelo fato da enxertia ser realizada mais alta, evita-se problemas de franqueamento e ataque de doenças na região da enxertia. Outra grande vantagem é a possibilidade de realizar mais de uma enxertia por planta, reduzindo as falhas na formação do vinhedo. 


\section{CONCLUSÕES}

Diante dos resultados, conclue-se que:

1)O diâmetro das estacas lenhosas não afeta o pegamento, mas estacas mais grossas originam mudas mais vigorosas.

2)A estaquia semilenhosa pode ser realizada utilizando-se estacas preparadas com apenas uma gema e uma folha, sem a necessidade de aplicação de auximas.

3)A micropropagação dos porta-enxertos 'Jales' e 'Campinas' pode ser realizada através do seguinte protocolo: cultivo inicial de ápices meristemáticos ou segmentos nodais em meio de cultura MS/2 (com a metade da concentração de sais) acrescido de $10 \mu \mathrm{M}$ de BAP; multiplicação através do subcultivo de segmentos nodais das brotações com uma folha, em meio de cultura $\mathrm{MS} / 2$ isento de reguladores de crescimento; o enraizamento ocorre naturalmente durante a multiplicação; aclimatização das plantas em recipientes fechados por 3 semanas e mais 4 semanas sob nebulização antes da transferência para recipientes ao ar livre.

4)Os porta-enxertos 'Jales' e 'Campinas' obtidos pela estaquia semilenhosa e micropropagação não permitem a execução da enxertia lenhosa durante o primeiro ano de crescimento, pelo pequeno diâmetro de seus caules. 
5)As mudas do cultivar Itália obtidas pela enxertia de mesa apresentam desenvolvimento inicial inferior às obtidas pela enxertia a campo na estaca ou na brotação do porta-enxerto. 


\section{REFERÊNCIAS BIBLIOGRÁFICAS}

AlbuQuerque, J. A. S. de; AlbuQuerque, T. C. S. de. Método para enraizamento de estacas de videira na região do sub-médio São Francisco. Petrolina: EMBRAPA-CPATSA, 1981a. 8p. (Circular Técnica, 2).

ALBUQUERQUE, J.A.S. de; ALBUQUERQUE, T.C.S. de. Enxertia da videira na região do sub-médio São Francisco. Petrolina: EMBRAPA-CPATSA, 1981b. 18p. (Circular Técnica, 7).

ALLEY, C.J. Propagation of grapevines. California Agriculture, v. 34, n.7, p. 29-30. 1980.

ALLEWELDT, G.; RADLER, F. Interrelationship between photoperiodic behavior of grapes \& growth of plant tissue cultures. Plant Physiology, v. 37, n. 3, p. 376-379. 1962.

ALTMAN, A.; WAREING, P.F. The effect of IAA on sugar accumulation and basipetal transport of ${ }^{14} \mathrm{C}$-labelled Phaseolus vulgaris cuttings. Physiologia Plantarum, v. 33, p. 32-38. 1975.

ALVARENGA, L.R. de. Estudo do enraizamento de quatro variedades de portaenxertos de videira com emprego do ácido indol butírico.In: CONGRESSO BRASILEIRO DE FRUTICULTURA, 3., Rio de Janeiro, 1975. Anais. Campinas: Sociedade Brasileira de Fruticultura, 1976. v. 2, p. 597-602. 
ALVARENGA, L.R. de. Produção de mudas de videira enxertadas no verão. Belo Horizonte: EPAMIG, 1984. 20p. (Boletim Técnico, 9).

ALVARENGA, L.R. de; FORTES, J.M. Enraizamento e desenvolvimento aéreo de alguns porta-enxertos de videira no município de Viçosa. In: CONGRESSO BRASILEIRO DE FRUTICULTURA, 3., Rio de Janeiro, 1975. Anais. Campinas: Sociedade Brasileira de Fruticultura, 1976. v. 2, p. 591-595.

ALVARENGA, L.R. de; TEIXEIRA, S.L.; FORTES, J.M.; OLIVEIRA, L.M. de; ANDERSEN, O. Estudos de processos de enxertia de verão sobre oito variedades de porta-enxertos, em videira (Vitis sp.). Revista Ceres, v. 24, $\mathbf{n}$. 136, p. 539-548. 1977.

ANACLERIO, F.; COSMI, T.; MORETTI, G. Il miglioramento qualitativo delle produzioni vivaistiche. Vignevini, n. 11, p. 43-46. 1992.

ARDAIZ, C.M.W.; RUÍZ, M.J.M. Propagación por estaquilla leñosa de Vitis vinifera L., var. Zalema. Denominación de Origen Condado de Huelva. Viticultura/Enologia Profesional, n. 25, p. 29-40. 1993.

BARLASS, M. Elimination of stem pitting and corky bark diseases from grapevine by fragmented shoot apex culture. Annals of Applied Biology, v. 110, p. 653-656. 1987.

BARLASS, M.; SKENE, K.G.M. In vitro propagation of grapevine (Vitis vinifera L.) from fragmented shoot apices. Vitis, v. 17, p. 335-340. 1978.

BARLASS, M.; SKENE, K.G.M. Studies on the fragmented shoot apex of grapevine. I. The regenerative capacity of leaf primordial fragments in vitro. Journal of Experimental Botany, v. 31, n. 121, p. 483-488. 1980a. 
BARLASS, M.; SKENE, K.G.M. Studies on the fragmented shoot apex of grapevine. II. Factors affecting growth and differentiation in vitro. Journal of Experimental Botany, v. 31, n. 121, p. 489-495. 1980 b.

BARLASS, M.; SKENE, K.G.M.; CLINGELEFFER, P.R. Studies on the fragmented shoot apex of grapevine. III. A scanning electron microscope study of adventitious bud formation in vitro. Journal of Experimental Botany, v. 32, n. 130, p.1079-1083. 1981.

BARLASS, M.; SKENE, K.G.M.; WOODHAM, R.C.; KRAKE, L.R. Regeneration of virus-free grapevines using in vitro apical culture. Annals of Applied Biology, v. 101, p. 291-295. 1982.

BARROS, J.C. da S. M. de. Avaliação da capacidade de enraizamento e desenvolvimento vegetativo e caracterização ampelográfica de híbridos de videira visando sua utilização como porta-enxertos. Piracicaba, 1995. 184p. Tese (Doutorado) - Escola Superior de Agricultura "Luiz de Queiroz", Universidade de São Paulo.

BASS, P.; CLOG, E.; WALTER, B. Improvements in apex culture in Vitis species. Acta Horticulturae, n. 227, p. 485-488. 1988.

BARTOLINI, G.; FABBRI, A.; TATTINI, M. Effect of phenolic acids on rhizogenesis in a grape rootstock ("140 Ruggeri") cuttings. Acta Horticulturae, n. 227, p. 242-247. 1988.

BARTOLINI, G.; TOPONI, M.A.; SANTINI, L. Endogenous GA-like substances in dipping waters of cuttings of two Vitis rootstocks. American Journal of Enology and Viticulture, v. 37, n. 1, p. 1-6. 1986.

BAUTISTA A., D.; VARGAS G., G. La inmersion en agua y diferentes ambientes de estratificacion en el prendimiento de estacas de la vid 'Criolla Negra'. Agronomia Tropical, v. 34, n. 1/4, p. 111-118. 1984. 
BAUTISTA A., D.; VARGAS G., G.; COLMENARES, J.C.; FREITEZ, Y. de. Efecto de algunos factores en el enraizamiento y brotacion de la vid 'Criolla Negra'. Agronomia Tropical, v. 31, n. 1/6, p. 59-68. 1981.

BERNABE, A.G. de L.G. de; MONREAL, M.G. Sobre la distribuicion del sistema radicular de la vid. Anales del Instituto Nacional de Investigaciones Agrarias, n. 20, p. 35-67. 1982.

BINDRA, A.S.; CHANANA, Y.R.; SINGH, A. Grafting unrooted cuttings of grapes. Indian Journal of Horticulture, v. 31, n. 1, p. 23-27. 1974.

BLAZINA, I.; RAVNIKAR, M.; ZOLNIR, M.; KOROSEC-KORUZA, Z.; GOGALA, N. Regeneration of GFLV-free grapevines and synchronization of micropropagation in vitro. Acta Horticulturae, n. 289, p. 87-88. 1991a.

BLAZINA, I.; KOROSEC-KORUZA, Z.; RAVNIKAR, M.; ZOLNIR, M.; GOGALA, N. Regeneration and micropropagation of the grapevine (Vitis vinifera L. 'Zelen') from shoot tip meristems. Acta Horticulturae, n. 300, p. 123-126. 1991b.

BLENNERHASSETT, R.M.; CONSIDINE, J.A. Propagation of Vitis champini Planchon cv Ramsey, storage and field practices. American Journal of Enology and Viticulture, v. 30, n. 2, p. 79-80. 1979.

BOHM, W. Methods of studying root systems. Berlim: Springer-Verlag. 1979. $189 \mathrm{p}$.

BOTTI, C.; GARAY, L.; REGINATO, G. The influence of culture dates, genotype and size and type of shoot apices on in vitro shoot proliferation of Vitis vinifera cvs Thompson Seedless, Ribier and Black Seedless. Vitis, v. 32, n.2, p. 125-126. 1993.

BOUBALS, D. La culture in vitro et la production de plants greffes-soudes. Progrès Agricole et Viticole, v. 104, n. 13-14, p. 311-314. 1987. 
BREEN, P.J.; MURAOKA, T. Effect of leaves on carbohydrate content and movement of ${ }^{14} \mathrm{C}$-assimilate in plum cuttings. Journal of the American Society for Horticultural Science, v. 99, p. 326-332. 1974.

CAMARGO, U. A. Utilização da enxertia verde na formação de plantas de videira no campo. Bento Gonçalves: EMBRAPA-CNPUV, 1992. 3p. (Comunicado Técnico, 9).

CANCELLIER, S.; COSSIO, F. Field observations on a clone of "Corvina Veronese" (Vitis vinifera L.) multiplied by "in vitro" culture. Acta Horticulturae, n. 227, p. 508-513. 1988.

CASTRO, P.R.C.; MELOTTO, E.; SOARES, F.C.; PASSOS, I.R.S.; POMMER, C.V. Rooting stimulation in muscadine grape cuttings. Scientia Agricola, Piracicaba, v. 51, n. 3, p. 436-440. 1994.

CHÉE, R.; POOL, R.M. The effects of growth substances and photoperiod on the development of shoot apices of Vitis cultured in vitro. Scientia Horticulturae, v. 16, n. 1, p. 17-27. 1982.

CHÉE, R.; POOL, R.M. In vitro vegetative propagation of Vitis: application of previously defined culture conditions to a selection of genotypes. Vitis, v. 22, n. 4 , p. $363-374.1983$.

CHÉE, R.; POOL, R.M. In vitro propagation of Vitis: the effects of organic substances on shoot multiplication. Vitis, v. 24, p. 106-118. 1985.

CHÉE, R.; POOL, R.M. Improved inorganic media constituents for in vitro shoot multiplication of Vitis. Scientia Hoticulturae, v. 32, n. 1-2, p. 85-95. 1987.

CHÉE, R.; POOL, R.M. Sucrose and NAA influence growth of subcultured shoots and in vitro production of roots in Vitis. HortScience, v. 23, n. 4, p. 776. 1988. 
CHÉE, R.; POOL, R.M. Morphogenic responses to propagule trimming, spectral irradiance, and photoperiod of grapevine shoots recultured in vitro. Journal of the American Society for Horticultural Science, v. 114, n. 2, p. 350354. 1989.

CICCOTTI, A.M. Micropropagazione di Vitis vinifera L. cvs. Moscato d'Amburgo e Pinot bianco. Esperienze e Ricerche, Stazione Sperimentale Agraria Forestale di S. Michele all'Adige, v. 11, p. 73-81. 1982.

COPPOLA, V.; FORLANI, M. Prove di radicazione su alcuni portinnesti della vite. Rivista di Viticoltura e di Enologia, v. 38, n. 11, p. 566-575. 1985.

COWART, F.F.; SAVAGE, E.F. The effect of various treatments and methods of handling upon rooting of muscadine grape cuttings. Proceedings of the American Society for Horticultural Science, v. 44, p. 312-314. 1944.

DALAL, M.A.; SHARMA, B.B.; RAO, M.S. Studies on stock plant treatment and initiation culture mode in control of oxidative browning in in vitro cultures of grapevine. Scientia Horticulturae, v. 51, n. 1-2, p. 35-41. 1992.

DAVIS, T.D. Photosynthesis during adventitious rooting. In: DAVIS, T.D.; HAISSIG, B.E.; SANKHLA, N. ed. Adventitious root formation in cuttings. Portland: Dioscorides Press, 1988. cap. 16, p. 214-234.

DURAN-VILA, N.; JUÁREZ, J.; ARREGUI, J.M. Production of viroid-free grapevines by shoot tip culture. American Journal of Enology and Viticulture, v. 39, n. 3, p. 217-220. 1988.

EGGER, E.; MORETTI, G.; BORGO, M. Confronto di substrati per la moltiplicazione rapida di talee verdi ed apici vegetativi di portinnesti della vite in serra. Vignevini, v. 12, n. 4, p. 43-49. 1985. 
FABBRI, A.; LAMBARDI, M. Effects of stock plant CCC treatments on adventitious rooting in "140 Ruggeri" cuttings. Acta Horticulturae, n. 227, p. 260-262. 1988.

FABBRI, A.; LAMBARDI, M.; SANI, P. Treatments with CCC and $\mathrm{GA}_{3}$ on stock plants and rooting of cuttings of the grape rootstock 140 Ruggeri. American Journal of Enology and Viticulture, v. 37, n. 3, p. 220-223. 1986.

FANIZZA, G.; RICCIARDI, L.; SILVESTRONI, O.; BOSCIA, D. The influence of high temperatures and benzyladenine on root induction during in vitro shoot tip culture in Vitis vinifera L. Acta Horticulturae, n. 227, p. 479-481. 1988.

FANIZZA, G.; TANZARELLA, O.A.; CARROZZO, G. Influence of Vitis source on in vitro shoot apex culture. Annals of Applied Biology, v. 104, p. 577578. 1984.

GALZY, R. Technique de thermothérapie des viroses de la vigne. Ann. Epiphyties, v. 15, n. 3, p. 245-256. 1964.

GALZY, R. Remarques sur la nutrition carbonée de la vigne cultivée in vitro. Bulletin de l'Office International de la Vigne et du Vin, v. 63, n. 707-708, p. 5-20. 1990.

GALZY, R.; HAFFNER, V.; COMPAN, D. Influence of three factors on the growth and nutrition of grapevine microcuttings. Journal of Experimental Botany, v. 41, n. 224, p. 295-301. 1990.

GALZY, R. \& COMPAN, D. Growth and nutrition of grapevine during in vitro long-term storage. Plant Cell, Tissue and Organ Culture, v. 13, n. 3, p. 229-237. 1988. 
GALZY, F. \& COMPAN, D. Remarks on mixotrophic and autotrophic carbon nutrition of Vitis plantlets cultured in vitro. Plant Cell, Tissue and Organ Culture, v. 31, n. 3, p. 239-244. 1992.

GARGIULO, A.A. Injerto en 'T' leñoso. Buenos Aires: Publicaciones, Prensa y Difusión del INTA, 1976. 27p.

GOBATO, C. Manual do viti-vinicultor brasileiro. Porto Alegre: Livraria Globo, 1940. 422p.

GOLDSMITH, M.H.M. Maintenance of polarity of auxin movement by basipetal transport. Plant Physiology, v. 41, p. 749-754. 1966.

GOODE JUNIOR, D.Z.; KREWER, G.W.; LANE, R.P.; DANIELL, J.W.; COUVILLON, G.A. Rooting studies of dormant muscadine grape cuttings. HortScience, v. 17, n. 4, p. 644-645. 1982.

GOODE JUNIOR, D.Z.; LANE, R.P. Rooting leafy muscadine grape cuttings. HortScience, v. 18, n. 6, p. 944-946. 1983.

GOUSSARD, P.G. Effects of cytokinins on elongation, proliferation and total mass of shoots derived from shoot apices of grapevine cultured in vitro. Vitis, v. 20, n. 3, p. 228-234. 1981.

GOUSSARD, P.G. Morphological responses of shoot apices of grapevine cultured in vitro. Effects of cytokinins in routine subculturing. Vitis, v. 21, n. 4, p. 293-298. 1982.

GRAY, D.J.; BENTON, C.M. Micropropagation and plant establishment of muscadine grape. Proceedings of the Florida State Horticultural Society, v. 103, p. 300-302. 1990. 
GRAY, D.J.; BENTON, C.M. In vitro micropropagation and plant establishment of muscadine grape cultivars (Vitis rotundifolia). Plant Cell, Tissue and Organ Culture, v. 27, n. 1, p. 7-14. 1991.

GRAY, D.J.; FISHER, L.C. In vitro shoot propagation of grape species, hybrids and cultivars. Proceedings of the Florida State Horticultural Society, v. 98, p. 172-174. 1985.

GRIBAUDO, I.; FRONDA, A. Effects of thidiazuron on grapevine axillary buds cultivated in vitro. HortScience, v. 26, n. 8, p. 1083. 1991.

HAISSIG, B.E. Carbohydrate accumulation and partitioning in Pinus banksiana seedlings and seedling cuttings. Physiologia Plantarum, v. 61, p. 13-19. 1984.

HARMON, F.N. Influence of indolebutyric acid on the rooting of grape cuttings. Proceedings of the American Society for Horticultural Science, v. 42, p. 383-388. 1943.

HARRIS, R.E.; STEVENSON, J.H. In vitro propagation of Vitis. Vitis, v. 21, $\mathbf{n}$. 1, p. 22-32. 1982.

HARTMANN, H.T.; KESTER, D.E.; DAVIES JUNIOR, F.T. Plant propagation: principles and practices. 5 ed. Englewood Cliffs: Prentice Hall, 1990. 647p.

HASSANI, Z. Influence de l'acide bêta-indole-butyrique (A.I.B.) sur le comportement des microgreffes de vigne cultivées in vitro. Progrès Agricole et Viticole, v. 107, n. 17, p. 375-379. 1990.

HASSANI, Z.; BOUBALS, D. Le microgreffage in vitro: une technique rapide et efficace de révélation du virus de la nécrose des nervures de 110 Richter. Progrès A gricole et Viticole, v. 108, n. 20, p. 443-445. 1991. 
HESS, C.E. Internal and external factors regulating root initiation. In: WHITTINGTON, W.J. ed. Root Growth. London: Butterworths, 1969. p. 42-53.

HIDALGO, L.; CANDELA, M.R. Morfologia radicular de la vid. Su relacion con la produccion, densidad y disposicion del viñedo. Madrid: Instituto Nacional de Investigaciones Agronomicas, 1969. 101p.

KORUZA, B.; JELASKA, S. Influence of meristem culture and virus elimination on phenotypical modifications of grapevine (Vitis vinifera L., cv. Refosk). Vitis, v. 32, n. 1, p. 59-60. 1993.

KRUL, W.R.; MOWBRAY, G.H. Grapes. In: SHARP, W.R.; EVANS, D.A.; AMMIRATO, P.V.; YAMADA, Y., ed. Handbook of Plant Cell Culture. New York: Macmillan Publishing Company, 1984. cap. 6, p 396-434.

KUHN, G.B.; LOVATEL, J.L.; PREZOTTO, O.P.; RIVALDO, O.F. 0 cultivo da videira: informações básicas. 2 ed. Bento Gonçalves: EMBRAPA, 1984. 44p. (Circular Técnica, 10).

LEE, N.; WETZSTEIN, Y. In vitro propagation of muscadine grape by axillary shoot proliferation. Journal of the American Society for Horticultural Science, v. 115, n. 2, p. 324-329. 1990.

LEONEL, S.; RODRIGUES, J.D. Efeito da época de estaquia, fitorreguladores e ácido bórico no enraizamento de estacas de porta-enxertos de videira. Scientia Agricola, v. 50, n. 1, p. 27-32. 1993.

LEWANDOWSKI, V.T. Rooting and acclimatization of micropropagated Vitis labrusca 'Delaware'. HortScience, v. 26, n. 5, p. 586-589. 1991.

LI, J.; EATON, G.W. Growth and rooting of grape shoot apices in vitro. HortScience, v. 19, n. 1, p. 64-66. 1984. 
LLOYD, G.; McCOWN, B. Commercially-feasible micropropagation of mountain laurel, Kalmia latifolia, by use of shoot-tip culture. International Plant Propagators' Society Combined Proceedings, v. 30, p. 421-427. 1986.

$\mathrm{LOACH}, \mathrm{K}$. Controlling environmental conditions to improve adventitious rooting. In: DAVIS, T.D.; HAISSIG, B.E.; SANKHLA, N. ed. Adventitious root formation in cuttings. Portland: Dioscorides Press, 1988. cap. 18, p. 248-273.

MARTIN, C.; COLLAS, A. De la culture in vitro a la production de grefféssoudés issus du greffage herbacé de la vigne. Progrès Agricole et Viticole, v. 109, n. 3, p. 61-68. 1992.

MARTINEZ, E.A.; TIZIO, R. Grapevine micropropagation through shoot tips and minicuttings from in vitro cultured one-node cuttings. HortScience, $v$. 24, n. 3, p. 513. 1989.

MARTINEZ, M.C.; MANTILLA, J.L.G. Estudio comparativo entre plantas de Vitis vinifera L. cv. Albariño, adultas, de in vitro y de semilla, de quatro años o más, cuando han sido sometidas a una poda lo más baja posible en madera del año, y cepas del mismo cultivar de in vitro y de semilla de dos años o menos, sometidas a la misma poda. Viticultura/Enologia Profesional, n. 26, p. 33-41. 1993.

MARTINEZ, M.C.; MANTILLA, J.L.G. Morphological and yield comparison between Vitis vinifera L. cv. Albariño grown from cuttings and from in vitro propagation. American Journal of Enology and Viticulture, v. 46, n. 2, p. 195-203. 1995.

MARTINO, L. Il microinnesto in vitro della vite. Petria, v. 2 (supplemento 1), p. 17-25. 1992. 
MARTINs, F.P.; SCARANARI, H.J.; RIBEIRO, I.J.A.; TERRA, M.M.; IGUE, T.; PEREIRA, F.M. Valor comparativo de cinco porta-enxertos para a cultivar de uva de mesa Patrícia (IAC 871-41). In: CONGRESSO BRASILEIRO DE FRUTICULTURA, 6., Recife, 1981. Anais. Recife: Sociedade Brasileira de Fruticultura, 1981. v. 4, p. 1300-1310.

MOE, R.; ANDERSEN, A.S. Stock plant environment and subsequent adventitious rooting. In: DAVIS, T.D.; HAISSIG, B.E.; SANKHLA, N. ed. Adventitious root formation in cuttings. Portland: Dioscorides Press, 1988. cap. 16 , p. $214-234$.

MORETTI, G.; BORGO, M. Stimolazioni ed antagonismi nel campo dei fitoregolatori rizogeni in vitigni portinnesti. Vignevini, v. 12, n. 11, p. 3136. 1985.

MULLINS, M.G.; NAIR, Y.; SAMPET, P. Rejuvenation in vitro: induction of juvenile characters in an adult clone of Vitis vinifera L. Annals of Botany, v. 44 , p. 623-627. 1979.

MURASHIGE, T. Plant propagation through tissue culture. Annual Review of Plant Physiology, v. 25, p. 135-166. 1974.

MURASHIGE, T.; SKOOG, F. A revised medium for rapid growth and bio assays with tobacco tissue cultures. Physiologia Plantarum, v. 15, p. 473479. 1962.

NACHTIGAL, J.C.; HOFFMANN, A.; KLUGE, R.A.; FACHINELLO, J.C.; MAZZINI, A.R. de A. Enraizamento de estacas semilenhosas de araçazeiro (Psidium cattleyanum Sabine) com o uso do ácido indolbutírico. Revista Brasileira de Fruticultura, v. 16, n. 1, p. 229-235. 1994.

NOVÁK, F.J.; JUVOVÁ, Z. Clonal propagation of grapevine through in vitro axillary bud culture. Scientia Horticulturae, v. 18, n. 3, p. 231-240. 1983. 
NITSCH, J.P.; NITSCH, C. Haploid plants from pollen grains. Science, v. 163, p. 85-87. 1969.

PASSOS, I. R. da S. Desenvolvimento de metodologia para a obtenção de embriogênese somática em videira. Piracicaba, 1991. 188p. Dissertação (Mestrado) - Escola Superior de Agricultura "Luiz de Queiroz", Universidade de São Paulo.

PASSOS, I.R. da S.; SONDAHL, M.R.; RIBEIRO, I.J.A.; TERRA, M.M.; PIRES, E.J.P. Cultura in vitro de meristemas de videira. I. Concentrações do hormônio 6-BA em meio primário. Bragantia, v. 44, n. 1, p. 473-479. 1985.

PEARSE, H.L. The effect of nutrition and phytohormones on the rooting of vine cuttings. Annals of Botany, v. 7, n. 26, p. 123-132. 1943.

PEIXOTO, P.H.P; PASQUAL, M.; CHALFUN, N.N.J.; ALVARENGA, A.A. de. Enraizamento e multiplicação "in vitro" de porta-enxertos de videira (Vitis spp L.). Revista Brasileira de Fruticultura, v. 16, n. 1, p. 178-184. 1994.

PEREIRA, F.M.; HIROCE, R.; IGUE, T.; OLIVEIRA, J.C. de. Pegamento, desenvolvimento e extração de macronutrientes de cinco diferentes portaenxertos de videira. In: CONGRESSO BRASILEIRO DE FRUTICUlTURA, 4., Salvador, 1977. Anais. Cruz das Almas: Sociedade Brasileiro de Fruticultura, 1978. p. 333-341.

PEREIRA, F.M.; LEITÃO FILHO, H.F. Caracterização botânica de portaenxertos de videira. Campinas: Instituto Agronômico, 1973. 19p. (Boletim Técnico, 7).

PEREIRA, F.M.; MARTINS, F.P.; INFORZATO, R. Enraizamento de estacas de três porta-enxertos de videiras: Traviú, $420 \mathrm{~A}$ e IAC 313, com o emprego do fitormônio ácido alfanaftalenoacético. In: CONGRESSO BRASILEIRO DE FRUTICULTURA, 1., Campinas, 1971. Anais. Campinas: Sociedade Brasileiro de Fruticultura, 1971. v. 2, p. 725-731. 
PEREIRA, F.M.; OIOLI, A.A.P.; BANZATTO, D.A. Enraizamento de diferentes tipos de estacas enfolhadas de goiabeira (Psidium guayava L.) em câmaras de nebulização. Científica, v. 11, n. 2, p. 239-244. 1983.

PERUZZO. E.L. Método de forçagem para produção de mudas de videira. Novas técnicas permitem alcançar melhores resultados. Agropecuária Catarinense, v. 8, n. 2, p. 17-19. 1995.

PERUZZO, E.L.; DAL BÓ, M.A. Propagação da videira e do quivi pela enxertia de garfagem a campo. Agropecuária Catarinense, v. 5, n. 2, p. 45-47. 1992.

PICCOLI, P.J. Formação de mudas de videira. Agropecuária Catarinense, v. 2, n. 3, p.17-19. 1989.

PIRE, R. Densidad longitudinal de raices y extraccion de humedad en un viñedo de el Tocuyo - Venezuela. Agronomia Tropical, v. 35, n. 1-3, p. 5-20. 1985.

POMMER, C. V. Uva. In: FURLANI, A. M. C.; VIEGAS, G. P., ed. O melhoramento de plantas no Instituto Agronômico. Campinas: Instituto Agronômico, 1993. cap. 13, p. 489-524.

RAVINDRA, M.B.; THOMAS, P. Sachet technique - an efficient method for the acclimatization of micropropagated grapes (Vitis vinifera L.). Current Science, v. 68, n. 5, p. 546-548. 1995.

REUSTLE, G.; MANN, M.; HEINTZ, C. Experience and problems with infections in tissue culture of grapevine. Acta Horticulturae, n. 225, p. 119127. 1988.

REUVENI, O.; RAVIV, M. Importance of leaf retention to rooting of avocado cuttings. Journal of the American Society for Horticultural Science, v. 106, n. 2, p. 127-130. 1981. 
RIBAS, W.C.; CONAGIN, A. Variedades de cavalos de videira e sua melhor época de enraizamento. Bragantia, v. 16, p. 127-138. 1957.

RIBAS, W.C.; FRAGA JUNIOR, C.G. Comparação de três tipos de mudas na instalação de um vinhedo. Bragantia, v. 19, n. 6, p. 63-71. 1960.

ROBACKER, C.D.; CHANG, C.J. Shoot-tip culture of muscadine grape to eliminate Pierce's disease bacteria. HortScience, v. 27, n. 5, p. 449-450. 1992.

ROBBINS, J.A.; BURGER, D.W. Propagation California wild grape. California Agriculture, v. 40, n. 5/6, p. 9-10. 1986.

ROMBERGER, G.A.; HAESELER, C.W.; BERGMAN, E.L. Influence of two callusing methods on benchgrafting success of 12 Vitis vinifera $\mathrm{L}$. combinations in Pennsylvania. American Journal of Enology and Viticulture, v. 30, n. 2, p. 106-110. 1979.

ROUBELAKIS-ANGELAKIS, K.A.; ZIVANOVITC, S.B. A new culture medium for in vitro rhizogenesis of grapevine (Vitis spp.) genotypes. HortScience, v. 26, n. 12, p. 1551-1553. 1991.

SAMPAIO, V.R. Videira - variações de enxertia por garfagem. In: CONGRESSO BRASILEIRO DE FRUTICULTURA, 4., Salvador, 1977. Anais. Cruz das Almas: Sociedade Brasileira de Fruticultura, 1978. p. 343-346.

SHARPE, R.H. Rooting of muscadine grapes under mist. Proceedings of the American Society for Horticultural Science, v. 63, p. 88-90. 1954.

SHIMOYA, C.; GOMIDE, C.J.; FORTES, J.M. Estudo anatômico do enraizamento e da soldadura do enxerto em estaca-enxerto de videira (Vitis spp.). Revista Ceres, v. 18, n. 96, p. 85-102. 1971. 
SILVA, A L. da; FACHINELLO, J. C.; MACHADO, A. A. Efeito do ácido indolilbutírico na enxertia e enraizamento da videira. Pesquisa Agropecuária Brasileira, v. 21, n. 8, p. 865-871. 1986.

SKENE, K.G.M.; BARLASS, M. Micropropagation of grapevine. International Plant Propagators' Society Combined Proceedings, v. 30, p. 564-570. 1980.

SKENE, K.G.M.; BARLASS, M. Studies on the fragmented shoot apex of grapevine. IV. Separation of phenotypes in a periclinal chimera in vitro. Journal of Experimental Botany, v. 34, n. 147, p. 1271-1280. 1983.

SOUSA, J.S.I. de. Uvas para o Brasil. Piracicaba: FEALQ, 1996. 791p.

SUDARSONO; GOLDY, R.G. Growth regulator and axillary bud position effects on in vitro establishment of Vitis rotundifolia. HortScience, v. 26, $\mathrm{n}$. 3, p. 304-307. 1991.

TAYLOR, H.M.; WILLATT, S.T. Utilization of rhizotrons in root research. In: RUSSELL, R.S.; IGUE, K.; MEHTA, Y.R. ed. The soil/root system in relation to Brazilian agriculture. Londrina: Fundação Instituto Agronômico do Paraná, 1981. p. 3 19-337.

TERRA, M.M.; FAHL, J.I.; RIBEIRO, I.J.A.; PIRES, E.J.P.; MARTINS, F.P.; SCARANARI, H.J.; SABINO, J.C. Efeitos de reguladores de crescimento no enraizamento de estacas de quatro porta-enxertos de videira. In: CONGRESSO BRASILEIRO DE FRUTICULTURA, 6., Recife, 1981. Anais. Recife: Sociedade Brasileira de Fruticultura, 1981. v. 4, p. 12651277.

TERRA, M.M.; PIRES, E.J.P.; NOGUEIRA, N.A.M. Tecnologia para produção de uva Itália na região noroeste do Estado de São Paulo. Campinas: Coordenadoria de Assistência Técnica Integral, 1993. 51p. (Documento técnico, 97). 
TERRA, M.M.; PIRES, E.J.P.; PETTINELLI JUNIOR, A.; POMMER, C.V.; SABINO, J. C.; PASSOS, I. R. da S.; COELHO, S. M. B. M.; SILVA, A.C.P. da; RIBEIRO, I.J.A. Produtividade de cultivares IAC de uvas para vinho como produtores diretos e sobre diferentes porta-enxertos. Bragantia, v. 49 , n. 2 , p. $345-362$. 1990 a.

TERRA, M.M.; PIRES, E.J.P.; COELHO, S. M. B. M.; PASSOS, I. R. da S.; SANTOS, R.R. dos; POMMER, C.V.; SILVA, A.C.P. da; RIBEIRO, I.J.A. Porta-enxertos para o cultivar Máximo IAC 138-22 de uvas de vinho em Monte Alegre do Sul, SP. Bragantia, v. 49, n. 2, p. 363-369. $1990 \mathrm{~b}$.

TERRA, M.M.; PIRES, E.J.P.; POMMER, C.V.; PASSOS, I. R. da S.; MARTINS, F.P.; RIBEIRO, I.J.A. Comportamento de porta-enxertos para o cultivar de uva de mesa Niagara Rosada, em Jundiaí, SP. In: CONGRESSO BRASILEIRO DE FRUTICULTURA, 9., Campinas, 1987. Anais. Campinas: Sociedade Brasileira de Fruticultura, 1988a. v. 2, p. 721-725.

TERRA, M.M.; RIBEIRO, I.J.A.; PIRES, E.J.P.; PASSOS, I.R. da S.; MARTINS, F.P. Influência da época de plantio e de substratos no enraizamento de estacas de porta-enxertos de videira. In: SIMPÓSIO LATINOAMERICANO DE ENOLOGIA E VITICULTURA, 2.; JORNADA LATINO-AMERICANA DE VITICULTURA E ENOLOGIA, 2.; $\mathrm{e}$ SIMPÓSIO ANUAL DE VITIVINICULTURA, 2., Garibaldi/Bento Gonçalves, 1987. Anais. Bento Gonçalves: Associação Brasileira dos Técnicos em Viticultura e Enologia, 1988b. p. 291-295.

THIES, K.L.; GRAVES JUNIOR, C.H. Meristem micropropagation protocols for Vitis rotundifolia Michx. HortScience, v. 27, n. 5, p. 447-449. 1992.

TIZIO, R.; ALMELA PONS, G.; TRIONE, S.O.; TRIPPI, V.S. Estudios sobre enraizamiento en vid. VII. Auxinas, inhibidores y la capacidad rizógena de las estacas. Phyton, v. 20, n. 1, p. 1-12. 1963. 
TIZIO, R.; TRIPPI, V.S.; TRIONE, S.O.; ALMELA PONS, G. Estudios sobre enraizamiento en vid. VI. Interacción de substancias de crescimiento y ciertos cofatores sobre el proceso de morfogénesis radical. Phyton, v. 17, $\mathbf{n}$. 1, p. 25-38. 1961.

TRIONE, S.O.; ALMELA PONS, G.; TIZIO, R.; TRIPPI, V.S. Estudios sobre enraizamiento en vid. VIII. Variación anual de la capacidad rizógena y su relación con tratamientos hormonales. Phyton, v. 20, n. 1, p. 13-18. 1963.

TRONCOSO, A.; CANTOS, M.; LIÑÁN, J.; PRIETO, J.; SARMIENTO, R. The use of "in vitro" culture and tubular container system to propagate selected grapevine plants for sherry wine production. Acta Horticulturae, n. 227, p. 358-362. 1988.

WARMUND, M.R.; STARBUCK, C.J.; LOCKSHIN, L. Growth, cold hardiness, and carbohydrate content of Vidal Blanc grapevines propagated by hardwood vs. softwood cuttings. American Journal of Enology and Viticulture, v. 37, n. 3, p. 215-219. 1986.

WETZSTEIN, H.Y.; MYERS, S.C. Vegetative and yield component characteristics of micropropagated muscadine grape (Vitis rotundifolia Michx.). Journal of Horticultural Science, v. 69, n. 4, p. 747-753. 1994.

WILLIAMS, P.L.; ANTCLIFF, A.J. Successful propagation of Vitis berlandieri and Vitis cinerea from hardwood cuttings. American Journal of Enology and Viticulture, v. 35, n. 2, p. 75-76. 1984.

WINKLER, A.J.; COOK, J.A.; KLIEWER, W.M.; LIDER, L.A. General viticulture. Berkeley: University of California Press, 1974. 710p.

YU, D.; MEREDITH, C.P. The influence of explant origin on tissue browning and shoot production in shoot tip cultures of grapevine. Journal of the American Society for Horticultural Science, v. 111, n. 6, p. 972-975. 1986. 
ZANETTE, F.; COMEM, J.J. Estudo do sistema radicular das plantas. In: REUNIÃO BRASILEIRA DE FERTILIDADE DO SOLO E NUTRIÇÃO DE PLANTAS, 20., Piracicaba, 1992. Anais. Campinas: Fundação Cargill, 1992. p. $395-403$. 


\section{APÊNDICES}


APÊNDICE 1. Resumo da análise de variância do efeito do diâmetro das estacas lenhosas no pegamento, número de brotações por estaca, número de folhas por brotação, comprimento médio das brotações e comprimento médio dos entrenós para os porta-enxertos 'Jales' e 'Campinas'.

\begin{tabular}{|c|c|c|c|c|c|c|}
\hline \multirow{2}{*}{$\begin{array}{l}\text { Causas de } \\
\text { variação }\end{array}$} & \multirow[t]{2}{*}{ GL } & \multicolumn{5}{|c|}{$\mathrm{QM}$} \\
\hline & & $\begin{array}{l}\text { Pegamento } \\
\text { (\%) }\end{array}$ & $\begin{array}{c}\text { Número de } \\
\text { brotações/ } \\
\text { estaca }\end{array}$ & $\begin{array}{l}\text { Número de } \\
\text { folhas/ } \\
\text { brotação }\end{array}$ & $\begin{array}{l}\text { Comprimento } \\
\text { das brotações } \\
\text { (cm) }\end{array}$ & $\begin{array}{l}\text { Comprimento } \\
\text { dos entrenós } \\
(\mathrm{cm})\end{array}$ \\
\hline Diâmetro & 2 & $4,84 \mathrm{~ns}$ & $0,02 \mathrm{~ns}$ & $17,44 * * *$ & $1504,09 * * *$ & $3,71 * * *$ \\
\hline PE & 1 & $14,98 \mathrm{~ns}$ & $1,78 * * *$ & $361,15^{* * *}$ & $22517,32 * * *$ & $46,45 * * *$ \\
\hline Diâm. x PE & 2 & $85,74 \mathrm{~ns}$ & $0,0 \operatorname{lns}$ & $1,33 \mathrm{~ns}$ & $140,27 *$ & $0,21^{*}$ \\
\hline Resíduo & 60 & 45,31 & 0,04 & 1,29 & 36,11 & 0,06 \\
\hline Total & 65 & & & & & \\
\hline
\end{tabular}

ns Não significativo.

*Significância estatística ao nível de $5 \%$ de probabilidade de erro.

***Significância estatística ao nível de $0,1 \%$ de probabilidade de erro.

APÊNDICE 2. Resumo da análise de variância do efeito da forma de preparo de estacas semilenhosas na porcentagem de enraizamento, porcentagem de retenção foliar e número de raízes por estaca do porta-enxertos 'Tropical'.

\begin{tabular}{lcccc}
\hline Causa.j de & GL & \multicolumn{3}{c}{ QM } \\
\cline { 3 - 5 } variação & & Enraizamento (\%) & Retenção foliar (\%) & Raízes/estaca (nº) \\
\hline Tratamentos & 2 & 23,66 ns & $39,91 \mathrm{~ns}$ & $3,56 \mathrm{~ns}$ \\
Resíduo & 9 & 196,37 & 276,14 & 1,15 \\
\hline Total & 11 & & & \\
\hline
\end{tabular}

ns Não significativo.

APÊNDICE 3. Resumo da análise de variância do efeito da forma de preparo de estacas semilenhosas na porcentagem de enraizamento, porcentagem de retenção foliar e número de raízes por estaca do porta-enxertos 'Jales'.

\begin{tabular}{lcccc}
\hline Causas de & GL & \multicolumn{3}{c}{ QM } \\
\cline { 3 - 5 } variação & & Enraizamento (\%) & Retenção foliar (\%) & Raízes/estaca ( $\left.\mathbf{n}^{0}\right)$ \\
\hline Tratamentos & 2 & $249,2 \ln s$ & $40,46 \mathrm{~ns}$ & $11,39^{* *}$ \\
Resíduo & 9 & 75,28 & 75,27 & 1,35 \\
\hline Total & 11 & & & \\
\hline
\end{tabular}

ns Não significativo.

**Significância estatística ao nível de $1 \%$ de probabilidade de erro. 
APÊNDICE 4. Resumo da análise de variância do efeito da forma de preparo de estacas semilenhosas na porcentagem de enraizamento, porcentagem de retenção foliar e número de raízes por estaca do porta-enxertos 'Campinas'.

\begin{tabular}{lcccc}
\hline Causas de & GL & \multicolumn{3}{c}{ QM } \\
\cline { 3 - 5 } variação & & Enraizamento (\%) & Retenção foliar (\%) & Raízes/estaca (ñ $)$ \\
\hline Tratamentos & 2 & $17,43 \mathrm{~ns}$ & $23,10 \mathrm{~ns}$ & $10,79 * * *$ \\
Resíduo & 9 & 28,88 & 84,84 & 0,32 \\
\hline Total & 11 & & & \\
\hline
\end{tabular}

ns Não significativo.

***Significância estatística ao nível de $0,1 \%$ de probabilidade de erro.

APÊNDICE 5. Resumo da análise de variância do efeito do AIB e dos portaenxertos 'Jales', 'Campinas', 'Riparia do Traviú' e 'Kober 5BB' na porcentagem de enraizamento, porcentagem de retenção foliar, porcentagem de brotação, mortalidade e número de raízes por estaca semilenhosa.

\begin{tabular}{|c|c|c|c|c|c|c|}
\hline \multirow{2}{*}{$\begin{array}{l}\text { Causas de } \\
\text { variação }\end{array}$} & \multirow[t]{2}{*}{ GL } & \multicolumn{5}{|c|}{$\mathrm{QM}$} \\
\hline & & $\begin{array}{c}\text { Enraizamento } \\
(\%)\end{array}$ & $\begin{array}{l}\text { Retenção } \\
\text { foliar (\%) }\end{array}$ & $\begin{array}{c}\text { Brotação } \\
(\%)\end{array}$ & $\begin{array}{l}\text { Mortalidade } \\
\text { (\%) }\end{array}$ & $\begin{array}{c}\text { Raízes/estaca } \\
\left(\mathrm{n}^{2}\right)\end{array}$ \\
\hline$\overline{A I B}$ & 3 & $195,26 \mathrm{~ns}$ & $358,8 \operatorname{lns}$ & $423,65 \mathrm{~ns}$ & $9,24^{* *}$ & $14,04^{* * *}$ \\
\hline PE & 3 & $1241,65^{* *}$ & $6239,92 * * *$ & $8464,88 * * *$ & $3,30 \mathrm{~ns}$ & $27,06 * * *$ \\
\hline $\mathrm{AIB} \times \mathrm{PE}$ & 9 & $63,90 \mathrm{~ns}$ & $236,27 \mathrm{~ns}$ & $346,06 \mathrm{~ns}$ & $0,59 \mathrm{~ns}$ & $3,08 \mathrm{~ns}$ \\
\hline Resíduo & 48 & 201,21 & 371,32 & 216,17 & 2,09 & 1,91 \\
\hline Total & 63 & & & & & \\
\hline
\end{tabular}

APÊNDICE 6. Resumo da análise de variância do efeito do AIB em quatro portaenxertos na mortalidade e número de raízes por estaca semilenhosa.

\begin{tabular}{|c|c|c|c|}
\hline \multirow{2}{*}{$\begin{array}{l}\text { Causas de } \\
\text { variação }\end{array}$} & \multirow[t]{2}{*}{ GL } & \multicolumn{2}{|c|}{$\mathrm{QM}$} \\
\hline & & Mortalidade (\%) & Raízes/estaca $\left(\mathrm{n}^{\circ}\right)$ \\
\hline Regressão linear & 1 & $26,91^{* *}$ & $39,67^{* * *}$ \\
\hline Regressão quadrática & 1 & $0,79 \mathrm{~ns}$ & $0,2 \operatorname{lns}$ \\
\hline Regressão cúbica & 1 & $0,01 \mathrm{~ns}$ & $2,22 \mathrm{~ns}$ \\
\hline Resíduo & 48 & 2,09 & 1,91 \\
\hline Total & 63 & & \\
\hline
\end{tabular}

ns Não significativo.

**Significância estatística ao nível de $1 \%$ de probabilidade de erro.

***Significância estatística ao nível de $0,1 \%$ de probabilidade de erro. 
APÊNDICE 7. Resumo da análise de variância do efeito do AIB na porcentagem de enraizamento, porcentagem de retenção foliar, porcentagem de brotação, mortalidade e número de raízes por estaca semilenhosa do porta-enxerto 'Tropical'.

\begin{tabular}{lcccccc}
\hline $\begin{array}{l}\text { Causas de } \\
\text { variação }\end{array}$ & GL & \multicolumn{5}{c}{ QM } \\
\cline { 2 - 7 } & $\begin{array}{c}\text { Enraizamento } \\
(\%)\end{array}$ & $\begin{array}{c}\text { Retenção } \\
\text { foliar (\%) }\end{array}$ & $\begin{array}{c}\text { Brotação } \\
(\%)\end{array}$ & $\begin{array}{c}\text { Mortalidade } \\
(\%)\end{array}$ & $\begin{array}{c}\text { Raízes/estaca } \\
\left(\mathbf{n}^{\circ}\right)\end{array}$ \\
\hline AIB & 3 & $62,23 \mathrm{~ns}$ & $115,80 \mathrm{~ns}$ & $5,09^{*}$ & $2,28 \mathrm{~ns}$ & $2,11 \mathrm{~ns}$ \\
Blocos & 3 & $15,92 \mathrm{~ns}$ & $23,14 \mathrm{~ns}$ & $5,81^{*}$ & $0,57 \mathrm{~ns}$ & $2,50 \mathrm{~ns}$ \\
Resíduo & 9 & 31,35 & 61,73 & 0,88 & 1,30 & 1,90 \\
\hline Total & 15 & & & & & \\
\hline
\end{tabular}

ns Não significativo.

*Significância estatística ao nível de $5 \%$ de probabilidade de erro.

APÊNDICE 8. Resumo da análise de variância do efeito da área foliar na porcentagem de enraizamento, porcentagem de brotação e mortalidade de estacas semilenhosas do porta-enxerto 'Jales'.

\begin{tabular}{lcccc}
\hline Causas de & GL & \multicolumn{3}{c}{ QM } \\
\cline { 3 - 5 } variação & & Enraizamento (\%) & Brotação (\%) & Mortalidade (\%) \\
\hline Tratamentos & 4 & $7583,63^{* * *}$ & $642,87^{* *}$ & $1576,17^{* * *}$ \\
Blocos & 3 & $60,48^{*}$ & $56,53 \mathrm{~ns}$ & $50,68 \mathrm{~ns}$ \\
Resíduo & 12 & 15,94 & 65,59 & 69,31 \\
\hline Total & 19 & & & \\
\hline
\end{tabular}

ns Não significativo.

*Significância estatística ao nível de $5 \%$ de probabilidade de erro.

**Significância estatística ao nivel de $1 \%$ de probabilidade de erro.

***Significância estatística ao nível de $0,1 \%$ de probabilidade de erro.

APÊNDICE 9. Resumo da análise de variância do efeito da área foliar no peso, volume e número de raízes por estaca semilenhosa do portaenxerto 'Jales'.

\begin{tabular}{lcccc}
\hline Causas de & GL & & QM & \\
\cline { 3 - 5 } variação & & Peso $(\mathrm{g})$ & Volume $(\mathrm{ml})$ & Número de raízes \\
\hline Tratamentos & 4 & $2,01^{* * *}$ & $1,73^{* * *}$ & $27,32^{* * *}$ \\
R. linear & 1 & $7,86^{* * *}$ & $6,82^{* * *}$ & $95,79^{* * *}$ \\
R. quadrática & 1 & $0,15^{*}$ & $0,11^{*}$ & $1,79^{* * *}$ \\
R. cúbica & 1 & $0,02 \mathrm{~ns}$ & $0,003 \mathrm{~ns}$ & $1,48 \mathrm{~ns}$ \\
Desvios da reg. & 1 & $0,002 \mathrm{~ns}$ & $0,01 \mathrm{~ns}$ & $0,04 \mathrm{~ns}$ \\
Blocos & 3 & $0,01 \mathrm{~ns}$ & $0,009 \mathrm{~ns}$ & $0,09 \mathrm{~ns}$ \\
Resíduo & 12 & 0,02 & 0,01 & 0,33 \\
\hline Total & 19 & & \\
\hline ns Não significativo. & \\
*Significância estatística ao nível de $5 \%$ de probabilidade de erro. \\
***Significância estatística ao nível de $0,1 \%$ de probabilidade de erro.
\end{tabular}


APÊNDICE 10. Resumo da análise de variância do efeito da área foliar na porcentagem de enraizamento, porcentagem de brotação e mortalidade de estacas semilenhosas do porta-enxerto 'Campinas'.

\begin{tabular}{lcccc}
\hline Causas de & GL & \multicolumn{3}{c}{ QM } \\
\cline { 3 - 5 } variação & & Enraizamento (\%) & Brotação (\%) & Mortalidade (\%) \\
\hline Tratamentos & 4 & $7834,56^{* * *}$ & $706,72^{*}$ & $1533,59^{* * *}$ \\
Blocos & 3 & $5,52 \mathrm{~ns}$ & $57,73 \mathrm{~ns}$ & $9,85 \mathrm{~ns}$ \\
Resíduo & 12 & 5,52 & 151,16 & 67,29 \\
\hline Total & 19 & & & \\
\hline
\end{tabular}

ns Não significativo.

*Significância estatística ao nível de $5 \%$ de probabilidade de erro.

***Significância estatística ao nível de $0,1 \%$ de probabilidade de erro.

APÊNDICE 11. Resumo da análise de variância do efeito da área foliar no peso, volume e número de raízes por estaca semilenhosa do portaenxerto 'Campinas'.

\begin{tabular}{lcccc}
\hline Causas de & GL & & QM & \\
\cline { 3 - 5 } variação & & Peso $(\mathrm{g})$ & Volume $(\mathrm{ml})$ & Número de raízes \\
\hline Tratamentos & 4 & $2,67^{* * *}$ & $2,52^{* * *}$ & $151,42^{* * *}$ \\
R. linear & 1 & $10,08^{* * *}$ & $9,43^{* * *}$ & $523,45^{* * *}$ \\
R. quadrática & 1 & $0,49^{*}$ & $0,50^{*}$ & $67,54^{* *}$ \\
R. cúbica & 1 & $0,11 \mathrm{~ns}$ & $0,14 \mathrm{~ns}$ & $14,52 \mathrm{~ns}$ \\
Desvios da reg. & 1 & $0,008 \mathrm{~ns}$ & $0,002 \mathrm{~ns}$ & $0,19 \mathrm{~ns}$ \\
Blocos & 3 & $0,05 \mathrm{~ns}$ & $0,06 \mathrm{~ns}$ & $1,96 \mathrm{~ns}$ \\
Resíduo & 12 & 0,08 & 0,08 & 5,04 \\
\hline Total & 19 & & & \\
\hline
\end{tabular}

ns Não significativo.

*Significância estatística ao nível de $5 \%$ de probabilidade de erro.

**Significância estarística ao nível de $1 \%$ de probabilidade de erro.

***Significância estatística ao nível de $0,1 \%$ de probabilidade de erro.

APÊNDICE 12. Resumo da análise de variância da sobrevivência, comprimento da brotação, diâmetro da brotação, peso da parte aérea, peso e volume do sistema radicular de mudas dos porta-enxertos 'Jales', 'Campinas' e 'Tropical'.

\begin{tabular}{|c|c|c|c|c|c|c|c|}
\hline \multirow[b]{2}{*}{$\begin{array}{l}\text { Causas de } \\
\text { variação }\end{array}$} & \multirow[b]{2}{*}{ GL } & \multicolumn{6}{|c|}{$\mathrm{QM}$} \\
\hline & & $\begin{array}{l}\text { Sobrevi- } \\
\text { vência } \\
\text { (\%) }\end{array}$ & $\begin{array}{l}\text { Comprimento } \\
\text { da brotação } \\
\text { (cm) }\end{array}$ & $\begin{array}{c}\text { Diâmetro } \\
\text { de brotação } \\
(\mathrm{mm})\end{array}$ & $\begin{array}{c}\text { Peso da } \\
\text { parte aérea } \\
\text { (g) }\end{array}$ & $\begin{array}{l}\text { Peso do } \\
\text { sistema } \\
\text { radicular } \\
(\mathrm{g})\end{array}$ & $\begin{array}{l}\text { Volume do } \\
\text { sistema } \\
\text { radicular } \\
(\mathrm{ml}) \\
\end{array}$ \\
\hline PE & 2 & $277,7 \mathrm{~ns}$ & $131,3 *$ & $0,37 \mathrm{~ns}$ & $1,30 \mathrm{~ns}$ & $8,23 \mathrm{~ns}$ & $3,48 \mathrm{~ns}$ \\
\hline Resíduo & 6 & 77,7 & 15,4 & 0,12 & 2,55 & 5,69 & 7,93 \\
\hline Total & 8 & & & & & & \\
\hline
\end{tabular}


APÊNDICE 13. Resurno da análise de variância do efeito de BAP na porcentagem de explantes com crescimento e explantes com folha do porta-enxerto 'Jales' avaliados 30 e 60 dias após a instalação do experimento.

\begin{tabular}{lccccc}
\hline & & \multicolumn{5}{c}{ QM } \\
\cline { 3 - 6 } $\begin{array}{l}\text { Causas de } \\
\text { variação }\end{array}$ & GL & & \multicolumn{2}{c}{ Explantes com crescimento (\%) } & \multicolumn{2}{c}{ Explantes com folha (\%) } \\
\cline { 3 - 6 } & & 30 & 60 & 30 & 60 \\
\hline BAP & 3 & $6755,13^{* * *}$ & $6404,01^{* * *}$ & $2616,01^{* * *}$ & $3596,76^{* * *}$ \\
R. linear & 1 & $12512,74^{* * *}$ & $13077,71^{* * *}$ & $6980,92^{* * *}$ & $10347,52^{* * *}$ \\
R. quadr. & 1 & $7066,66^{* * *}$ & $6090,23^{* * *}$ & $835,02^{*}$ & $434,24^{*}$ \\
R. cúbica & 1 & $686,00 \mathrm{~ns}$ & $44,10 \mathrm{~ns}$ & $32,07 \mathrm{~ns}$ & $8,5 \ln$ \\
Blocos & 3 & $205,62 \mathrm{~ns}$ & $72,50 \mathrm{~ns}$ & $341,66 \mathrm{~ns}$ & $172,91 \mathrm{~ns}$ \\
Residuo & 9 & 83,90 & 139,05 & 141,66 & 72,91 \\
\hline Total & 15 & \multicolumn{5}{c}{} \\
\hline
\end{tabular}

ns Não significativo.

*Significância estatística ao nível de 5\% de probabilidade de erro.

***Significância estatística ao nível de $0,1 \%$ de probabilidade de erro.

APÊNDICE 14. Resumo da análise de variância do efeito de BAP na porcentagem de explantes com crescimento e explantes com folha do porta-enxerto 'Campinas' avaliados 30 e 60 dias após a instalação do experimento.

\begin{tabular}{|c|c|c|c|c|c|}
\hline \multirow{3}{*}{$\begin{array}{l}\text { Causas de } \\
\text { variação }\end{array}$} & \multirow{3}{*}{ GL } & \multicolumn{4}{|c|}{ QM } \\
\hline & & \multicolumn{2}{|c|}{ Explantes com crescimento (\%) } & \multicolumn{2}{|c|}{ Explantes com folha (\%) } \\
\hline & & 30 & 60 & 30 & 60 \\
\hline BAP & 3 & $6256, \overline{72 * * *}$ & $5462,01^{* * *}$ & $3740,01^{* * *}$ & $3173, \overline{67 * * *}$ \\
\hline R. linear & 1 & $15501,22 * * *$ & $12231,67 * * *$ & $10952,76 * * *$ & $9255,19 * * *$ \\
\hline R. quadr. & 1 & $3216,91 * * *$ & $3987,20 * * *$ & $20,36 \mathrm{~ns}$ & $18,93 \mathrm{~ns}$ \\
\hline R. cúbica & 1 & $52,02 \mathrm{~ns}$ & $167,15 \mathrm{~ns}$ & $246,90 \mathrm{~ns}$ & $246,90 \mathrm{~ns}$ \\
\hline Blocos & 3 & $172,54 \mathrm{~ns}$ & $141,66 \mathrm{~ns}$ & $116,33 \mathrm{~ns}$ & $116,16 \mathrm{~ns}$ \\
\hline Resíduo & 9 & 56,09 & 80,55 & 210,88 & 266,38 \\
\hline Total & 15 & & & & \\
\hline
\end{tabular}

ns Não significativo.

***Significância estatística ao nível de $0,1 \%$ de probabilidade de erro. 
APÊNDICE 15. Resumo da análise de variância do efeito do tempo de permanência no meio de indução sobre a porcentagem de explantes com crescimento, explantes com folha e oxidados do porta-enxerto 'Campinas'.

\begin{tabular}{lcccc}
\hline $\begin{array}{l}\text { Causas de } \\
\text { variação }\end{array}$ & GL & $\begin{array}{c}\text { Explantes com } \\
\text { crescimento (\%) }\end{array}$ & $\begin{array}{c}\text { Explantes com folha } \\
(\%)\end{array}$ & Oxidados (\%) \\
\hline Tratamentos & 4 & $506,66^{* *}$ & $633,33^{*}$ & $206,46^{* * *}$ \\
R. linear & 1 & $333,33^{*}$ & $2083,33^{* *}$ & $562,72^{* * *}$ \\
R. quadrática & 1 & $1609,52^{* * *}$ & $402,38 \mathrm{~ns}$ & $192,72^{* *}$ \\
R. cúbica & 1 & $83,33 \mathrm{~ns}$ & $0,00 \mathrm{~ns}$ & $53,30 \mathrm{~ns}$ \\
Desvios da reg. & 1 & $0,47 \mathrm{~ns}$ & $47,61 \mathrm{~ns}$ & $17,09 \mathrm{~ns}$ \\
Residuo & 10 & 46,66 & 180,00 & 13,30 \\
\hline Total & 14 & & & \\
\hline ns Não significativo. & & \\
*Significância estatistica ao nível de 5\% de probabilidade de erro. & \\
**Significância estatística ao nível de $1 \%$ de probabilidade de erro. \\
***Significância estatistica ao nível de $0,1 \%$ de probabilidade de erro.
\end{tabular}

APÊNDICE 16. Resumo da análise de variância do efeito de BAP na indução do crescimento de gemas axilares de segmentos nodais do portaenxerto 'Jales'.

\begin{tabular}{|c|c|c|c|c|c|}
\hline \multirow{2}{*}{$\begin{array}{l}\text { Causas de } \\
\text { variação }\end{array}$} & \multirow[t]{2}{*}{ GL } & \multicolumn{4}{|c|}{$\mathrm{QM}$} \\
\hline & & $\begin{array}{c}\text { Comprimento } \\
\text { da brotação } \\
(\mathrm{mm})\end{array}$ & Brotação (\%) & Oxidação (\%) & Calo (\%) \\
\hline Tratamentos & 4 & $47,84 * *$ & $151,56 \mathrm{~ns}$ & $330,63 \mathrm{~ns}$ & $8451,37 * * *$ \\
\hline R. linear & 1 & $30,97 \mathrm{~ns}$ & & & \\
\hline R. quadrática & 1 & $156,35^{* * *}$ & & & \\
\hline R. cúbica & 1 & $2,63 \mathrm{~ns}$ & & & \\
\hline Desvios da reg. & 1 & $1,40 \mathrm{~ns}$ & & & \\
\hline Resíduo & 15 & 8,37 & 87,06 & 267,39 & 35,9 \\
\hline
\end{tabular}

ns Não significativo.

**Significância estatística ao nível de $1 \%$ de probabilidade de erro.

***Significância estatística ao nível de $0,1 \%$ de probabilidade de erro. 
APÊNDICE 17. Resumo da análise de variância do efeito da posição do segmento nodal no crescimento de gemas axilares do porta-enxerto 'Jales'.

\begin{tabular}{|c|c|c|c|c|c|}
\hline \multirow{2}{*}{$\begin{array}{l}\text { Causas de } \\
\text { variação }\end{array}$} & \multirow[t]{2}{*}{ GL } & \multicolumn{4}{|c|}{ QM } \\
\hline & & $\begin{array}{c}\text { Comprimento } \\
\text { da brotação } \\
\text { (mm) }\end{array}$ & $\begin{array}{c}\text { Contaminação } \\
\text { (\%) }\end{array}$ & Oxidação (\%) & Calo (\%) \\
\hline Tratamentos & 6 & $56,17^{* * *}$ & $1,34 \mathrm{~ns}$ & $216,01 \mathrm{~ns}$ & $215,17 \mathrm{~ns}$ \\
\hline $\mathrm{R}$ linear & 1 & $315,57 * * *$ & & & \\
\hline $\mathrm{R}$ quadrática & 1 & $0,05 \mathrm{~ns}$ & & & \\
\hline $\mathrm{R}$ cúbica & 1 & $17,34 \mathrm{~ns}$ & & & \\
\hline Desvios da reg. & 3 & $1,35 n s$ & & & \\
\hline Resíduo & 21 & 8,54 & 3,93 & 266,51 & 1353,82 \\
\hline Total & 27 & & & & \\
\hline
\end{tabular}

ns Não significativo.

***Significância estatística ao nível de $0,1 \%$ de probabilidade de erro.

APÊNDICE 18. Resumo da análise de variância do efeito do meio de cultura sobre o crescimento do porta-enxerto 'Jales'.

\begin{tabular}{lccccccc}
\hline $\begin{array}{l}\text { Causas de } \\
\text { variação }\end{array}$ & GL & \multicolumn{7}{c}{ QM } \\
\cline { 2 - 7 } & & $\begin{array}{c}\text { Oxidação } \\
(\%)\end{array}$ & $\begin{array}{c}\text { Enraizamento } \\
(\%)\end{array}$ & $\begin{array}{c}\text { Raizes/ } \\
\text { explante }\left(\mathrm{n}^{\mathbf{0}}\right)\end{array}$ & $\begin{array}{c}\text { Comprimento } \\
\text { da brotação } \\
(\mathrm{mm})\end{array}$ & $\begin{array}{c}\text { Comprimento } \\
\text { dos entrenós } \\
(\mathrm{mm})\end{array}$ & $\begin{array}{c}\text { Folhas/ } \\
\text { brotação }\left(\mathrm{n}^{\circ}\right)\end{array}$ \\
\hline Meio & 4 & $394,16^{* *}$ & $1196,82^{* * *}$ & $1,86^{* *}$ & $171,15^{* *}$ & $1,40 \mathrm{~ns}$ & $4,97^{* * *}$ \\
Blocos & 3 & $415,47^{* *}$ & $19,94 \mathrm{~ns}$ & $0,24 \mathrm{~ns}$ & $12,21 \mathrm{~ns}$ & $1,99 \mathrm{~ns}$ & $0,76 \mathrm{~ns}$ \\
Residuo & 12 & 68,20 & 70,64 & 0,18 & 7,04 & 0,59 & 0,31 \\
\hline Total & 19 & & & \multicolumn{7}{c}{} & \\
\hline
\end{tabular}

ns Não significativo.

**Significância estatística ao nível de $1 \%$ de probabilidade de erro.

***Significância estatística ao nível de $0,1 \%$ de probabilidade de erro.

APÊNDICE 19. Resumo da análise de variância do efeito do tamanho da folha do explante durante o subcultivo na multiplicação do porta-enxerto 'Jales'.

\begin{tabular}{|c|c|c|c|c|c|c|}
\hline \multirow{2}{*}{$\begin{array}{l}\text { Causas de } \\
\text { variação }\end{array}$} & \multirow[t]{2}{*}{ GL } & \multicolumn{5}{|c|}{ QM } \\
\hline & & $\begin{array}{c}\text { Enraizamento } \\
\text { (\%) }\end{array}$ & $\begin{array}{c}\text { Raízes/ } \\
\text { explante }\left(\mathrm{n}^{\circ}\right)\end{array}$ & $\begin{array}{l}\text { Comprimento } \\
\text { da brotação } \\
(\mathrm{mm})\end{array}$ & $\begin{array}{c}\text { Brotação } \\
\text { (\%) }\end{array}$ & $\begin{array}{c}\text { Folhas/ } \\
\text { brotação }\left(n^{\circ}\right)\end{array}$ \\
\hline Tamanho & 3 & $4566,67 * * *$ & $2,43 * * *$ & $4,98 * * *$ & $4033,33 * * *$ & $6,08 * * *$ \\
\hline Residuo & 8 & 133,33 & 0,11 & 0,03 & 33,33 & 0,07 \\
\hline Total & 11 & & & & & \\
\hline
\end{tabular}


APÊNDICE 20. Resumo da análise de variância do efeito da posição do explante durante o subcultivo na multiplicação do porta-enxerto 'Jales'.

\begin{tabular}{|c|c|c|c|c|c|c|}
\hline \multirow{2}{*}{$\begin{array}{l}\text { Causas de } \\
\text { variação }\end{array}$} & \multirow[t]{2}{*}{ GL } & \multicolumn{5}{|c|}{$\mathrm{QM}$} \\
\hline & & $\begin{array}{c}\text { Enraizamento } \\
\mathbf{( \% )}\end{array}$ & $\begin{array}{l}\text { Comprimento } \\
\text { da brotação } \\
\text { (mm) }\end{array}$ & $\begin{array}{c}\text { Brotação } \\
\text { (\%) }\end{array}$ & $\begin{array}{c}\text { Raízes/ } \\
\text { explante }\left(n^{\underline{0}}\right)\end{array}$ & $\begin{array}{c}\text { Folhas/ } \\
\text { brotação }\left(\mathbf{n}^{\circ}\right)\end{array}$ \\
\hline Posição & 3 & $190,97^{*}$ & $0,36^{*}$ & $381,94 * *$ & $0,06 \mathrm{~ns}$ & $0,15 \mathrm{~ns}$ \\
\hline R. linear & 1 & $93,75 \mathrm{~ns}$ & $0,58 *$ & $843,75 * * *$ & & \\
\hline R. quadr. & 1 & $468,75^{* *}$ & $0,36^{*}$ & $208,33 *$ & & \\
\hline R. cúbica & 1 & $10,4 \operatorname{lns}$ & $0,15 \mathrm{~ns}$ & $93,75 \mathrm{~ns}$ & & \\
\hline Resíduo & 8 & 26,04 & 0,07 & 26,04 & 0,17 & 0,13 \\
\hline Total & 11 & & & & & \\
\hline
\end{tabular}

APÊNDICE 21. Resumo da análise de variância do efeito de diferentes formas de aclimatização na sobrevivência de mudas do porta-enxerto 'Jales'.

\begin{tabular}{lcc}
\hline Causas de variação & GL & QM \\
\hline Tratamentos & 1 & $112,50^{*}$ \\
Resíduo & 6 & 12,50 \\
\hline Total & 7 &
\end{tabular}

*Significância estatística ao nível de 5\% de probabilidade de erro.

APÊNDICE 22. Resumo da análise de variância do comprimento da brotação principal, comprimento total das brotações, comprimento dos entrenós e número total de gemas por planta obtida por estaquia e micropropagação dos porta-enxertos 'Jales' e 'Campinas'.

\begin{tabular}{lccccc}
\hline $\begin{array}{l}\text { Causas de } \\
\text { variação }\end{array}$ & GL & \multicolumn{5}{c}{ QM } \\
\cline { 3 - 6 } & $\begin{array}{c}\text { Comprimento } \\
\text { da brotação } \\
\text { principal }(\mathrm{cm})\end{array}$ & $\begin{array}{c}\text { Comprimento } \\
\text { total das } \\
\text { brotaç̃̃es }(\mathrm{cm})\end{array}$ & $\begin{array}{c}\text { Comprimento } \\
\text { dos entrenós } \\
(\mathrm{cm})\end{array}$ & $\begin{array}{c}\text { Número total } \\
\text { de gemas/ } \\
\text { planta }\end{array}$ \\
\hline Tratamentos & 3 & $2339,72^{* *}$ & $62729,28^{* * *}$ & $1,83^{* *}$ & $2492,42^{* * *}$ \\
Blocos & 3 & $593,18 \mathrm{~ns}$ & $7681,19 \mathrm{~ns}$ & $0,50 \mathrm{~ns}$ & $235,73 \mathrm{~ns}$ \\
Resíduo & 9 & 176,76 & 2812,94 & 0,20 & 120,78 \\
\hline Total & 15 & & & & \\
\hline
\end{tabular}

ns Não significativo.

**Significância estatística ao nível de $1 \%$ de probabilidade de erro.

*** Significância estatística ao nível de $0,1 \%$ de probabilidade de erro. 
APÊNDICE 23. Resumo da análise de variância do diâmetro da brotação principal, peso da parte aérea, peso do sistema radicular e volume do sistema radicular por planta obtida por estaquia $\mathrm{e}$ micropropagação dos porta-enxertos 'Jales' e 'Campinas'.

\begin{tabular}{|c|c|c|c|c|c|}
\hline \multirow{2}{*}{$\begin{array}{l}\text { Causas de } \\
\text { variação }\end{array}$} & \multirow[t]{2}{*}{ GL } & \multicolumn{4}{|c|}{$\mathrm{QM}$} \\
\hline & & $\begin{array}{c}\text { Diâmetro da } \\
\text { brotação } \\
\text { principal }(\mathrm{mm})\end{array}$ & $\begin{array}{c}\text { Peso da parte } \\
\text { aérea } \\
\text { (g) }\end{array}$ & $\begin{array}{l}\text { Peso do sistema } \\
\text { radicular } \\
\text { (g) }\end{array}$ & $\begin{array}{c}\text { Volume do } \\
\text { sistema } \\
\text { radicular (ml) }\end{array}$ \\
\hline Tratamentos & 3 & $1219,08 * * *$ & $10571,74 * * *$ & $777,03 * * *$ & $635,41 * *$ \\
\hline Blocos & 3 & $11,92 \mathrm{~ns}$ & $433,65 \mathrm{~ns}$ & $194,38 *$ & $195,67 \mathrm{~ns}$ \\
\hline Resíduo & 9 & 10,97 & 131,23 & 30,59 & 69,79 \\
\hline Total & 15 & & & & \\
\hline
\end{tabular}

ns Não significativo.

* Significância estatística ao nível de $5 \%$ de probabilidade de erro.

**Significância estatística ao nível de $1 \%$ de probabilidade de erro.

***Significância estatística ao nível de $0,1 \%$ de probabilidade de erro.

APÊNDICE 24. Resumo da análise de variância da porcentagem de falha na estaquia direta a campo dos porta-enxertos 'Jales' e 'Campinas'.

\begin{tabular}{lcc}
\hline Causas de variação & GL & QM \\
\hline Tratamentos & 3 & $566,34 \mathrm{~ns}$ \\
Blocos & 4 & $491,47 \mathrm{~ns}$ \\
Resíduo & 12 & 530,28 \\
\hline Total & 19 &
\end{tabular}

APÊNDICE 25. Resumo da análise de variância do desenvolvimento dos portaenxertos 'Jales' e 'Campinas' antes da enxertia.

\begin{tabular}{|c|c|c|c|c|c|}
\hline \multirow{2}{*}{$\begin{array}{l}\text { Causas de } \\
\text { variação }\end{array}$} & \multirow[t]{2}{*}{ GL } & \multicolumn{4}{|c|}{$\mathrm{OM}$} \\
\hline & & $\begin{array}{l}\text { Diâmetro da } \\
\text { estaca }(\mathrm{mm})\end{array}$ & $\begin{array}{l}\text { Diâmetro das } \\
\text { brotações }(\mathrm{mm})\end{array}$ & $\begin{array}{l}\text { Número de } \\
\text { brotações/ } \\
\text { estaca }\end{array}$ & $\begin{array}{l}\text { Peso das } \\
\text { brotações/ } \\
\text { planta }(\mathrm{g})\end{array}$ \\
\hline Tratamentos & 3 & $20,42 * * *$ & $3,87^{* *}$ & $0,06 \mathrm{~ns}$ & $6,96^{*}$ \\
\hline Blocos & 4 & $2,25 \mathrm{~ns}$ & $0,90 \mathrm{~ns}$ & $0,0 \operatorname{lns}$ & $1,18 \mathrm{~ns}$ \\
\hline Resíduo & 12 & 1.07 & 0,48 & 0.05 & 1,61 \\
\hline Total & 19 & & & & \\
\hline
\end{tabular}

ns Não significativo.

*Significância estatística ao nível de $5 \%$ de probabilidade de erro.

**Significância estatística ao nível de $1 \%$ de probabilidade de erro.

***Significância estatística ao nível de $0,1 \%$ de probabilidade de erro. 
APÊNDICE 26. Resumo da análise de variância do desenvolvimento das mudas obtidas pela enxertia de mesa sete meses após o plantio a campo.

\begin{tabular}{lcccc}
\hline $\begin{array}{l}\text { Causas de } \\
\text { variação }\end{array}$ & GL & \multicolumn{3}{c}{ QM } \\
\cline { 2 - 5 } & & $\begin{array}{c}\text { Mortalidade } \\
(\%)\end{array}$ & $\begin{array}{c}\text { Diâmetro da estaca } \\
(\mathrm{mm})\end{array}$ & $\begin{array}{c}\text { Diâmetro da copa } \\
(\mathrm{mm})\end{array}$ \\
\hline Tratamentos & 1 & $2208,79^{* *}$ & $9,27^{* *}$ & $0,44 \mathrm{~ns}$ \\
Blocos & 4 & $487,04 *$ & $0,11 \mathrm{~ns}$ & $0,1 \mathrm{~ns}$ \\
Resíduo & 4 & 70,11 & 0,17 & 0,13 \\
\hline Total & 9 & & & \\
\hline
\end{tabular}

ns Não significativo.

*Significância estatística ao nível de $5 \%$ de probabilidade de erro.

**Significância estatística ao nível de $1 \%$ de probabilidade de erro.

APÊNDICE 27. Resumo da análise de variância do comprimento da brotação da copa da 'Itália' enxertada sobre 'Jales' e 'Campinas' em diversas datas de avaliação.

\begin{tabular}{|c|c|c|c|c|c|c|c|c|}
\hline \multirow{2}{*}{$\begin{array}{l}\text { Causas de } \\
\text { variação }\end{array}$} & \multirow[t]{2}{*}{ GL } & \multicolumn{7}{|c|}{$\overline{Q M}$} \\
\hline & & $08 / 11 / 95$ & $07 / 12 / 95$ & $09 / 01 / 96$ & $08 / 02 / 96$ & $08 / 03 / 96$ & $09 / 04 / 96$ & $09 / 05 / 96$ \\
\hline$\overline{\mathrm{PE}}$ & 1 & $6220,8 * * *$ & $16319,3^{* * *}$ & $26671,0^{* * *}$ & $27609,4^{* * *}$ & $32775,7^{* * *}$ & $38988,1^{* * *}$ & $34544,1^{* * *}$ \\
\hline Tipo enxer. & 2 & $3019,2^{* * *}$ & $6928,4^{* * *}$ & $10035,2^{* * *}$ & $8982,6^{* * *}$ & $12276,4^{* * *}$ & $14288,3^{* * *}$ & $12340,5^{* * *}$ \\
\hline PE x Tipo & 2 & $925,8^{*}$ & $2584,5^{* *}$ & $3537,3^{* *}$ & $3687,4^{* *}$ & $3119,7^{* *}$ & $4000,9^{* *}$ & $3532,2 *$ \\
\hline Blocos & 4 & $312,1 \mathrm{~ns}$ & $433,7 \mathrm{~ns}$ & $613,6 \mathrm{~ns}$ & $613,4 \mathrm{~ns}$ & $1192,2 *$ & $990,3 \mathrm{~ns}$ & $810,2 \mathrm{~ns}$ \\
\hline Residuo & 20 & 172,6 & 258,1 & 355,7 & 354,7 & 401,7 & 484,7 & 619,6 \\
\hline
\end{tabular}

ns Não significativo.

*Significância estatistica ao nivel de $5 \%$ de probabilidade de erro.

**Significância estatistica ao nivel de $1 \%$ de probabilidade de erro.

***Significância estatistica ao nivel de $0,1 \%$ de probabilidade de erro.

APÊNDICE 28. Resumo da análise de variância do peso e do diâmetro das brotações da copa da 'Itália' enxertada sobre os porta-enxertos 'Jales' e 'Campinas'.

\begin{tabular}{lccc}
\hline Causas de & GL & & QM \\
\cline { 3 - 4 } variação & & Peso das brotações $(\mathrm{g})$ & Diâmetro das brotações $(\mathrm{mm})$ \\
\hline PE & 1 & $5612,35^{* * *}$ & $8,56^{* * *}$ \\
Tipo enxertia & 2 & $3436,24 * * *$ & $9,36^{* * *}$ \\
PE x Tipo enx. & 2 & $1545,55^{* * *}$ & $1,32^{*}$ \\
Blocos & 4 & $109,10 \mathrm{~ns}$ & $0,20 \mathrm{~ns}$ \\
Resíduo & 20 & 59,60 & 0,24 \\
\hline Total & 29 & & \\
\hline
\end{tabular}

ns Não significativo.

*Significância estatística ao nível de $5 \%$ de probabilidade de erro.

***Significância estatística ao nível de $0,1 \%$ de probabilidade de erro. 
APÊNDICE 29. Total pluviométrico, temperaturas médias máximas, temperaturas médias mínimas e temperaturas médias mensais ocorridas durante a realização do experimento a campo em Campinas (SP).

\begin{tabular}{llcccc}
\hline Ano & Meses & $\begin{array}{c}\text { Total } \\
\text { pluviométrico } \\
(\mathrm{mm})\end{array}$ & $\begin{array}{c}\text { Temperaturas } \\
\text { médias } \\
\text { máximas }\left({ }^{\circ} \mathrm{C}\right)\end{array}$ & $\begin{array}{c}\text { Temperaturas } \\
\text { médias } \\
\text { mínimas }\left({ }^{\circ} \mathrm{C}\right)\end{array}$ & $\begin{array}{c}\text { Temperaturas } \\
\text { médias } \\
\left({ }^{\circ} \mathrm{C}\right)\end{array}$ \\
\hline \multirow{6}{*}{1994} & Junho & 33,2 & 23,8 & 11,5 & 17,7 \\
& Julho & 30,3 & 25,7 & 12,1 & 18,9 \\
& Agosto & 0,0 & 27,0 & 13,0 & 20,0 \\
& Setembro & 0,0 & 30,1 & 15,8 & 23,0 \\
& Outubro & 54,9 & 31,1 & 18,9 & 25,0 \\
& Novembro & 168,3 & 29,7 & 18,6 & 24,2 \\
& Dezembro & 303,1 & 30,5 & 19,9 & 25,2 \\
\hline \multirow{6}{*}{1995} & Janeiro & 173,2 & 30,4 & 20,5 & 25,5 \\
& Fevereiro & 352,3 & 28,3 & 20,0 & 24,1 \\
& Março & 258,5 & 28,9 & 18,7 & 23,8 \\
& Abril & 108,3 & 27,6 & 16,6 & 22,1 \\
& Maio & 68,8 & 25,2 & 14,6 & 19,9 \\
& Junho & 32,9 & 24,8 & 12,6 & 18,7 \\
& Julho & 50,7 & 25,8 & 14,1 & 19,9 \\
& Agosto & 1,0 & 29,1 & 15,1 & 22,1 \\
& Setembro & 69,3 & 27,8 & 15,4 & 21,6 \\
& Outubro & 174,0 & 27,1 & 16,6 & 21,8 \\
& Novembro & 81,1 & 29,1 & 17,8 & 23,5 \\
& Dezembro & 247,8 & 29,2 & 18,9 & 24,1 \\
\hline & Janeiro & 322,7 & 30,2 & 20,2 & 25,2 \\
& Fevereiro & 214,2 & 30,4 & 20,1 & 25,3 \\
& Março & 202,2 & 29,4 & 19,3 & 24,4 \\
& Abril & 68,0 & 28,1 & 17,6 & 22,8 \\
& Maio & 36,8 & 25,0 & 14,2 & 19,6 \\
& Junho & 33,6 & 24,6 & 12,4 & 18,5 \\
\hline
\end{tabular}

Fonte: Instituto Agronômico, Seção de Climatologia Agrícola. 